\title{
EDIÇÃO ANOTADA DE MUCUFOS, COLETÂNEA DE CONTOS INÉDITA DE VALDOMIRO SILVEIRA
}

Dissertação de Mestrado

Programa de Pós-Graduação em Literatura Brasileira

Faculdade de Filosofia, Letras e Ciências Humanas

Universidade de São Paulo

Orientadora: Profa. Dra. Therezinha A. P. Ancona Lopez 


\section{ÍNDICE}

P.

Valdomiro Silveira e Mucufos

MUCUFOS: Edição anotada de uma coletânea inédita ..................................42

Manuscritos de Valdomiro Silveira no acervo do escritor.............................233 
In memoriam de:

minha mãe, a quem devo muito de minha formação escolar, acadêmica e de minha vida; meu pai e seu legado.

Para

minha filha Júlia da Silva Barbosa, querido "pedaço de mim”. 


\section{AGRADECIMENTOS}

À Profa. Telê Ancona Lopez, pela rigorosa e, ao mesmo tempo, pacienciosa orientação, principalmente nos momentos mais delicados do trabalho.

Aos Profs. Drs. Luiz Dagobert D’Aguirra Roncari, Jaime Ginzburg e Marcos Antonio de Moraes, pelas preciosas sugestões bibliográficas.

À Aline Marques, pela ajuda pontual.

Aos funcionários do Setor de Informática do IEB/USP, Dênis, Renato, Cazon e Cláudio, pelo auxílio providencial na parte de diagramação e montagem da dissertação.

Às funcionárias do Arquivo do IEB/ USP pela ajuda na consulta parte de manipulação de arquivos.

À Camila Koshiba, pela ajuda na organização do Arquivo Valdomiro Silveira.

Aos meus primos Armando, Rosane, Vera e Irene, pelo incentivo na continuidade do trabalho.

À Maria Elisa, outra prima querida, falecida em março, que também muito me apoiou nesta caminhada.

Às minhas tias Dorothy e Irahy, também pelo incentivo.

Aos colegas de trabalho Luno Volpato, Alexander Montero Cunha, Fernanda Aparecida Leonardi, Maristela Coccia e Marcelo Falcão, que se tornaram amigos.

À Daniele Gualtieri Rodrigues, pela providencial ajuda na reta final.

Ao Alexandre Barros Oliveira, da D.E. Campinas-Oeste, pelo estímulo à curiosidade.

À Maria Eugênia, da D.E. Campinas-Leste, pela compreensão.

À Janalice, pelo incentivo à garra.

Ao José Carlos e à Elza pelo incentivo à reflexão.

Aos amigos Marcelo Mari, Paulo José Cunha e Marcos Júnior, estudantes e moradores do CRUSP, que me cederam espaço em seus apartamentos nos momentos que precisei.

Aos meus mestres de Capoeira e de Tênis, Gladson de Oliveira Silva e Roberto Malavazzi, pelos ensinamentos esportivos e de vida. 
BARBOSA, Alexandre de Oliveira

Edição anotada de Mucufos, coletânea de contos inédita de Valdomiro Silveira

PALAVRAS-CHAVE: Valdomiro Silveira; contos; transcrição; notas; resgate.

\section{RESUMO}

Esta dissertação apresenta uma edição anotada de um livro inédito de contos de Valdomiro Silveira, Mucufos. A introdução situa historicamente esse livro, expõe as visões críticas a respeito do conjunto da obra do escritor, que envolvem aspectos sociais, humanos, estéticos e lingüísticos. Descreve o conjunto de contos de Mucufos encontrados em duas pastas denominadas Mucufos e Originaes manuscriptos de Papae (preciosíssimos), no Arquivo Valdomiro Silveira, no IEB/ USP, e explicita os critérios adotados na edição. Tal edição tem por finalidade estabelecer, a partir do confronto entre o apógrafo de CLSD (Carmen Lydia de Souza Dias), os autógrafos, os datiloscritos e os impressos encontrados nas pastas e no Arquivo do Estado, uma edição fidedigna. Para tanto, além do confronto referido, foi escolhida a transcrição crítica dos contos, procurando preservar os arcaísmos e os regionalismos presentes neles. A partir da transcrição, foram estabelecidos dois tipos de notas de rodapé. O primeiro, denominado de Nota CLSD, indica jornais de época em que foi publicada a maior parte dos contos, local e data de publicação, assim como local e data da escritura dos contos. O segundo, denominado Nota da edição, indica a pasta onde foi encontrado o conto e explica algumas palavras de cunho regional. Nas análises dos contos, buscou-se problematizar o teor de realismo, com a contribuição da categoria do realismo, segundo Georg Lukács; também foram analisadas as características estéticas, o grau de descrição de elementos da natureza e os principais temas e motivos. Entre estes últimos, destaca-se a violência e seu tratamento estético. Das análises, depreende-se a visão de Brasil por parte do escritor. A presente dissertação, pelo que foi exposto, busca resgatar uma parte do legado artístico de um escritor que muito se preocupou em humanizar um sujeito até então marginalizado em nossa literatura, o caipira, e discutir as principais questões estéticas e ideológicas surgidas nas análises dos 24 contos que constituem a edição. 
BARBOSA, Alexandre de Oliveira

Annotated edition of Mucufos, unpublished collection of short stories by Valdomiro Silveira

Keywords: Valdomiro Silveira; short stories; transcript; notes; salvage.

\begin{abstract}
This dissertation focuses on the annotated edition of an unpublished book of short stories, Mucufos, by Valdomiro Silveira. The introduction situates this book in a historical context, explaining critical views on the collected works of the writer, involving social, human, esthetical and linguistic aspects. It describes the short story collection of Mucufos found in two files named Mucufos and Originaes manuscriptos de Papae (especially valuable) in the Valdomiro Silveira Archive (IEB/ USP), and explains the criteria adopted for the edition. The aim of this edition was to establish an authentic edition emanating from a comparison between a reproduction by CLSD (Carmen Lydia de Souza Dias), autographs, typewritten sheets and printed papers found in the files and in the Office of Public Records. Apart from this comparison, a critical transcript of the short stories was chosen, in an attempt to preserve archaisms and regionalisms in these stories. Two types of footnotes were established from the transcript. The first note, named CLSD Note, indicates newspapers of the time period when most of the short stories were published, with publication date and location, as well as location and date when the stories were written. The second note, named Edition Note, indicates the file where the story was found, explaining some words of regional character. In an analysis of the short stories, there was an attempt to put in doubt the tenor of realism, with contribution from the category of realism, according to Georg Lukács; esthetical features, description of the elements, and main topics and motives were also analyzed. In the latter, violence and its esthetical treatment are highlighted. The writer's view of Brazil can be inferred from the analyses. Therefore, the current dissertation seeks to salvage part of the artistic legacy of a writer who was very concerned with humanizing an individual who had been marginalized in our literature until then, i.e. the hillbilly, and discuss the main esthetical and ideological issues that appear in the analyses of the 24 short stories of the edition.
\end{abstract}




\section{VALDOMIRO SILVEIRA E MUCUFOS}

A presente edição anotada de Mucufos, de Valdomiro Silveira (1873-1941), livro inédito programado por ele, tem como objetivo principal resgatar esta parcela do legado literário desse escritor tão significativo no regionalismo brasileiro. Mucufos reúne 24 contos, dos quais a maior parte escritos entre 1894 e 1938, dos quais 21 foram publicados em jornais entre 1894 e 1905.

Valdomiro Silveira nascido a 11 de novembro de 1873 em Senhor Bom Jesus da Cachoeira, Termo de Lorena, atual Cachoeira Paulista, cidade localizada no Vale do Paraíba, Estado de São Paulo, era o segundo dos oito filhos de João Batista da Silveira, advogado, e de Cristina da Silveira. Antes de completar um ano de vida, veio com a família para São Paulo, para que o pai pudesse ingressar na Faculdade de Direito, e formado, radicar-se como promotor em Casa Branca, onde Valdomiro desponta nas letras. Em 1890, com 17 anos, vai para a capital, também estudar Direito, e provavelmente nas férias em Casa Branca, escreve contos que saem imediatamente em jornais paulistanos. Concluído o curso em abril 1895, o jovem advogado parte para Santa Cruz do Rio Pardo, na qualidade de promotor público. Ali permanece por dois anos, regressando a Casa Branca, onde abre, com o pai, escritório de advocacia, no qual não se fixa. Segundo as notas biográficas da autoria de Júnia Silveira Mendes Gonçalves, inseridas na coletânea organizada por Bernardo Élis e Ruth Guimarães, $O$ mundo caboclo de Valdomiro Silveira, ao se mudar para Santos em 1905, o escritor já trabalhara por um tempo em São Paulo. Em 1905, casa-se com Maria Isabel Quartim de Moraes que, mais tarde, publicará o belo depoimento Isabel quis Valdomiro. Em Santos, dedica-se à advocacia, ao jornalismo e à ficção, até o final da vida, em 1941.

A obra de Valdomiro Silveira principia no final do período realista/ naturalista, isto é, na segunda metade do século xix, atravessa o pré-modernismo e dá, segundo Mário de Andrade, recado ao modernismo no que diz respeito à pesquisa e à adoção da língua portuguesa falada no Brasil. Os caboclos, 1920, Nas serras e nas furnas, 1931, e Mixuangos, em 1937, livros publicados em vida, completam-se com Leréias, de edição póstuma em 1945, e Mucufos, inédito que reúne 24 contos, escritos entre 1894 e 1938, dos quais 16 foram publicados em jornais paulistas, 5 em jornais cariocas e 3 nunca divulgados.

A coletânea de contos intitulada Mucufos por Valdomiro Silveira, ao que se pode compreender, apresentava-se em um datiloscrito original do escritor, ou em uma cópia 
datilografada pela filha mais velha dele, D. Júnia Silveira Mendes Gonçalves que, após a morte do pai, encarregou-se de cuidar do espólio. Entre novembro de 1973 e 1980, Carmen Lydia de Souza Dias, doutoranda orientada pela Profa. Telê Ancona Lopez, do Programa de Pós-Graduação em Literatura Brasileira da Faculdade de Filosofia, Letras e Ciências Humanas da Universidade de São Paulo, e bolsista da FAPESP, desenvolveu, no Arquivo Valdomiro Silveira, a pesquisa para sua tese, tendo por objeto a análise da obra do regionalista. Defendida em 1980, a tese foi publicada em 1984 como Paixão de raiz: Valdomiro Silveira e o regionalismo (São Paulo: Ática). Durante sua busca de dados, a pesquisadora realizou a transcrição de duas coletâneas inéditas - Mucufos e Simplicidade -, datilografando-os, e procedeu a microfilmagem de outros contos e crônicas, os quais se achavam no espólio, em recortes de periódicos, ao lado de "10 fascículos" dedicados a Estudos de vernáculo. Nesses cadernos, que estão entre 1894 e 1902, o ficcionista estudava. Recolhia em letra bem cuidada, escrevendo a tinta, construções por ele selecionadas na leitura daqueles que considerava "clássicos": autores portugueses como Herculano, Felinto Elísio, Castillho, Camilo Castelo Branco e Ramalho Ortigão. Percebe-se, por esses documentos, que o contista aproveitou seu retiro no interior paulista, não só para se familiarizar com a cultura e o falar caipira, como para construir a sólida erudição que também marca seu estilo, sua linguagem.

Carmen Lydia de Souza Dias depositou no Setor de Arquivos do Instituto de Estudos Brasileiros (USP) a documentação por ela levantada. Desta forma, esta edição contou, como texto-base, o apógrafo de Mucufos, isto é, o manuscrito datilografado da coletânea, tal como Valdomiro a organizara entre 1938 - data da redação dos últimos contos - e 1941, quando faleceu. Desses originais, conforme consigna o Índice, confirmado pela seqüência nos fólios, constavam os seguintes títulos: "Primeira queda", "Rabicho”, "Jurando falso", "Mutirão", “À hora da prisão", "Castigo do céu”, "Seo doutor", "Amaldiçoada”, "Bocó-de-mola", "João Maçarico", "Quebrante”, “Ânsia antiga”, "Soberbia”, "Soneira brava”, "Reis", "Capiango", "Forte teima!", "Os guaxes”, "Na rua do Bosque”, "Paixão de raiz", "Pazes”, "Moça do fandango", "Na beirada do taimbé" e "Cobras mal acostumadas", além de um "Vocabulário" destinado a essa obra.

Em sua transcrição, Carmen Lydia acrescentou esta nota de rodapé:

"Os 24 contos desta coletânea, inéditos em livro, foram cedidos para a minha pesquisa pela filha do autor, D. Júnia Silveira Mendes Gonçalves, que colocou junto de cada texto, os 
dados de que dispunha, relativos ao local de publicação, de feitura e respectivas datas. Tais informes aparecem ora completos, ora parciais". Pela nota, pode-se compreender que D. Júnia teria buscado em autógrafos e datiloscritos do pai, indicações essas que ele costumava apor aos manuscritos. De todo modo, fica-nos uma zona nebulosa, já que, a morte da primogênita de Valdomiro, precedida de um período em que ela não pode mais cuidar dos documentos, fez com que o arquivo perdesse a organização original. Tal fato se constata na documentação doada ao Instituto de Estudos Brasileiros em agosto de 2006 por Isabel Silveira Leal Góis e Ana Maria Leal Góis de Mello, respectivamente neta e bisneta de Valdomiro Silveira, documentação da qual não mais participa o volume que deu base ao apógrafo.

No Arquivo Valdomiro Silveira, hoje no IEB, as pastas Mucufos e Originaes manuscriptos de Papae (preciosíssimos), conservam, respectivamente, 12 e 13 títulos do livro planejado. Além disso, fecharam-se as possibilidades de maiores explicações por parte da pesquisadora, pois ela também faleceu. Restou-nos acatar as notas em que Carmen Lydia recupera datas de redação e de publicação, aqui denominadas Notas CLSD.

Essas notas nos permitem dispor os títulos em ordem cronológica, momentaneamente esquecendo a sequiência estabelecida pelo escritor. Desta forma, verifica-se que, no ano de 1894, a 10 de fevereiro, foi publicado, no paulistano Diário da Tarde, o conto "Primeira queda"; e que a 13 de setembro, o Diário Popular, também de São Paulo, estampou "Rabicho". Do mesmo modo, sabe-se que, em 1895, $1^{\circ}$ de setembro, o Correio Paulistano, trouxe "Jurando falso", e que, em 1896, a 3 e a 10 de janeiro, em $O$ Repórter, na cidade de São Paulo, saíram "Mutirão" bem como "À hora da prisão"; e ainda, que "Seo doutor", foi dividido em dois números em A Bruxa, suplemento do jornal carioca Gazeta de Notícias, a 9 e 16 de outubro. A cronologia mostra, na então capital do país, em 1897, "Bocó-de-mola", nos dias 1, 2 e 3 de junho, na Gazeta de Notícias, e "Quebrante", a 27 de agosto, em O Paiz. Em 1898, nos traz "Reis", escrito em Casa Branca, a 2 de janeiro, e "Ânsia antiga", a 8 de maio em $O$ Paiz, onde, em 20 de agosto de 1899, vem "Capiango". E exibe, entre 1902 a 1905, 11 títulos em $O$ Estado de S. Paulo. Em 1902, são 7: em janeiro, "Soneira brava" (dia 19); em fevereiro, "João Maçarico", "Forte teima!” e "Amaldiçoada”, com o título "Maldiçoada" (1e 10); em março, apareceu "Soberbia" (13); em abril "Os guaxes" (15) e em $1^{\text {o }}$ de setembro, "Na rua do Bosque". Em 1903, "Castigo do céu" a 18 de janeiro, e "Pazes", a 15 de outubro e, em 1905, "Moça do fandango" (16 de setembro). Além disso, pesquisa em O Estado de S. 
Paulo, ali localizou, a 11 de dezembro de 1902, "Paixão de raiz", "escrito em Casa Branca, em 3 de dezembro de 1902”, segundo a nota no apógrafo.

No final desta cronologia ficam os contos não publicados "Na beirada do taimbé" e “Cobras mal acostumadas”, escritos em Campos de Jordão, em 1938.

O apógrafo de CLSD indica que "João Maçarico" saiu no jornal O Estado de S. Paulo a $1^{\circ}$ de fevereiro de 1902 , coincidentemente mesmo jornal e data de publicação de "Forte teima!"; porém, em pesquisa realizada no Arquivo do Estado, não localizei "João Maçarico" na referida data, nem mesmo entre 1902 e 1905, período em que apareceram os títulos no jornal anteriormente citado.

No que diz respeito ao conjunto dos contos de Mucufos, pelo menos três apresentam características muito importantes. São eles: "Seo doutor", "Amaldiçoada" e "Bocó-de-mola".

"Seo doutor" mostra-se como um conto significativo na medida em que aproxima o discurso do narrador ao falar caipira das personagens, mesmo demarcando traços autobiográficos e instituindo um um alter ego do escritor. Logo no primeiro parágrafo do conto esses traços se fazem ver:

\footnotetext{
"Quando na fazenda se soube que Valdóro ia aos estudos, não houve quem não fechasse muxoxo e não levantasse ombreira, porque ninguém quis acreditar: um tal dizia que menino assim, que até os catorze anos não tomou tenência e é reinador e mexerendengo, foge das coisas sérias da vida, como o demo da cruz;"
}

"Amaldiçoada" mostra-se, segundo Carmen Lydia de Souza Dias, em Paixão de raiz: Valdomiro Silveira e o regionalismo, como um verdadeiro marco no conjunto de toda a produção literária de Valdomiro Silveira, pois se constitui em um dos mais bem acabados contos do escritor (os outros, em Mucufos, são "Quebrante" e "Pazes"), do ponto de vista da adequação do caso ao uso literário do falar caipira. Além disto, o texto é curto e não traz em si excesso de regionalismos, perífrases, apostos e vocábulos eruditos, como em outros contos. Outro aspecto que nos chama bastante atenção é a forma da narrativa. Ela foi elaborada, segundo a estudiosa (que faz uso do termo dialeto ao invés da expressão falar caipira), em "boa medida entre o tom narrativo semi-dialetal e o diálogo em dialeto".

\footnotetext{
${ }^{1}$ DIAS, Carmen Lydia de Souza. Paixão de raiz: Valdomiro Silveira e o regionalismo. São Paulo: Ática, 1984. p. 197.
} 
"Bocó-de-mola", segundo a mesma crítica, entra no agrupamento dos contos estilisticamente imaturos de Valdomiro Silveira, assim como "Castigo do céu", "Soneira brava", "Reis" e "Forte teima!"2. Segundo a mesma pesquisadora, "Bocó-de-mola" está entre os contos onde "o dialeto não foi adequado ao "causo", cujo conteúdo dele necessitava para se totalizar como experiência humano-regional, esteticamente válida. Isto ocorre porque o autor não inventou o caso para usar o dialeto"3. Além disso, observa-se que o texto é praticamente narrado em coloquial culto, traz quase nenhum diálogo e faz parte dos contos experimentais de Valdomiro, tomados como "repositório do "caso" para futura reelaboração"4. Esta expressão, que aparece aqui, assim como em certas análises dos contos de Mucufos, significa que o escritor se preocupou mais em registrar o caso, possivelmente ouvido em suas andanças pelo sertão, do que trabalhá-lo esteticamente bem, em perfeita comunhão com o falar caipira, no sentido de promover uma melhor adequação do discurso do narrador ao das personagens, gerando, assim, fluidez e espontaneidade na narrativa que, conseqüentemente, ganharia um maior teor de realismo.

\section{Valdomiro no contexto literário brasileiro}

Difícil se torna precisar uma estética, uma escola à qual o escritor pertence. A presença da natureza na produção de Valdomiro Silveira, por exemplo, constrói-se, de acordo com a herança romântica, como espaço físico propício a uma cultura diferenciada ${ }^{5}$, como no regionalismo romântico de Alencar em $O$ gaúcho. Do mesmo modo que, no romantismo, a natureza comunga os sentimentos das personagens ou reflete alegrias e dramas que as envolvem. Essa idealização, contudo, quando se trata de absorver a singularidade da cultura caipira, nos valores, nos usos e costumes, dá lugar a uma visão que se quer realista/ naturalista ácida, mas que, em diversos momentos, mergulha no pitoresco. Era um momento onde alguns escritores tentavam se libertar dos modismos europeus (basicamente franceses) e criar uma literatura genuinamente nacional.

Do realismo/ naturalismo Valdomiro herdou o gosto pela investigação científica do meio em que vivia, o qual procurava retratar literariamente, escudado nas idéias do

\footnotetext{
${ }^{2}$ DIAS, Carmen Lydia de Souza. Op. cit., p. 195.

${ }^{3}$ DIAS, Carmen Lydia de Souza. Op. cit., loc. cit.

${ }^{4}$ DIAS, Carmen Lydia de Souza. Op. cit., p. 196.

${ }^{5}$ A respeito do tratamento da natureza na literatura brasileira por parte de vários escritores, desde o romantismo até o pré-modernismo, passando pelo realismo/ naturalismo, ver CARVALHO, Flávia Paula. A natureza na literatura brasileira: regionalismo pré-modernista. São Paulo: Hucitec: Terceira Margem, 2005.
} 
Positivismo, do Evolucionismo e do Determinismo. Isto o fez estudar Botânica e Ornitologia para melhor descrever a natureza ao seu redor.

Do pré-modernismo herdou o gosto pela denúncia da realidade brasileira. Através de suas histórias caboclas, Valdomiro focalizava a realidade de um grupo social que vivia marginalizado economicamente; ligando-se ao regionalismo, ao abordar costumes e tipos humanos do interior de São Paulo. Nas obras pré-modernistas, a natureza poucas vezes surge como simples registro, quer seja no que se relaciona à paisagem ou aos vegetais, quer seja no que se relaciona a animais ou acidentes geográficos. Aparece associada a uma impressão ou estado de espírito do narrador, que, ao descrever, utiliza o processo metafórico, ou faz uma comparação com um elemento da vida humana ou da arte, segundo comenta Carmen Lydia de Souza Dias 6 .

Em relação ao modernismo, apesar de não ter participado da Semana de Arte de 22, foi considerado por Mário de Andrade um autêntico precursor do movimento, no que diz respeito ao uso literário de um tipo de falar característico de um determinado grupo social, popular e economicamente excluído:

“Também escritores de outras regiões procuram às vezes revelar a língua das nossas massas populares regionais, e as revelam admiravelmente. Valdomiro Silveira, por exemplo, cujos livros são verdadeiramente clássicos, como expressão do dizer caipira"7.

\section{$\underline{\text { A divergência da crítica }}$}

Apesar da dificuldade de colocar Valdomiro Silveira dentro de alguma escola literária, um crítico como Alfredo Bosi $^{8}$ o insere no realismo/ naturalismo, pelo fato do escritor ter se ocupado da investigação de cunho cientificista (e, por isso, bastante descritiva) da natureza ao seu redor e pelo empenho em levar adiante um programa marcadamente regionalista (com a valorização da cultura e do falar do caipira de São Paulo). Afirma Bosi, entretanto, que "o período entre 1890 e 1900 pode ser considerado como um pré-modernismo cronológico ou como um pré-modernismo de caráter ideológico, apresentando obras mais ou menos

\footnotetext{
${ }^{6}$ DIAS, Carmen Lydia de Souza. Op. cit., p. 61-66.

${ }^{7}$ ANDRADE, Mário de. "Pintor contista". In: __. O empalhador de passarinho. Belo Horizonte: Itatiaia, s.d. p. 60.

${ }^{8}$ BOSI, Alfredo. História concisa da literatura brasileira. $3^{\text {a }}$ ed. São Paulo: Cultrix, 1992. p. 232-243.
} 
relevantes, de acordo com a respectiva situação no interior desses dois conceitos" ${ }^{\text {. }}$. Ele coloca no pré-modernismo cronológico as obras "remanescentes da cultura realista-parnasiana" e associa ao pré-modernismo ideológico tudo aquilo que no princípio do século xx começa a problematizar a realidade econômica, social e cultural do Brasil ${ }^{10}$. Para Bosi, dentro do prémodernismo ideológico estão as obras que possuem uma forma ou temas que prenunciam posições estéticas e ideológicas que vigoraram depois do Movimento Modernista de 1922, tomado como marco histórico-ideológico no processo artístico de conscientização dos escritores em relação aos problemas sociais brasileiros ${ }^{11}$, e que colaboraram, de modo original e bem brasileiro, para a afirmação das conquistas culturais do realismo/ naturalismo. Ainda segundo o mesmo Bosi, a colaboração estético-ideológica de determinadas obras do prémodernismo "constitui verdadeiro sintoma do advento modernista, dentro de nosso contexto cultural deficitário do final do século xix e início do xx, período de pouca expressão criativa, a maior parte da literatura marcada por um caráter não polêmico e convencional" ${ }^{\prime 2}$.

Já, em outra posição, Flávia Paula Carvalho inclui Valdomiro Silveira entre os escritores do pré-modernismo, termo criado pelo crítico Tristão de Ataíde, por considerar que o regionalismo desenvolvido por pelo autor de Os caboclos apresenta, sobretudo, uma linha de identificação com o homem e com a paisagem, juntamente com uma maior fidelidade nos retratos, o que não é observado nos realistas. Isso implica afirmar que os regionalistas prémodernistas (incluídos por ela, neste grupo, além de Valdomiro Silveira, Afonso Arinos, Hugo de Carvalho Ramos, Simões Lopes Neto e Monteiro Lobato) retomam do romantismo o reconhecimento da terra ou da pátria como sendo próprios, porém fazendo uso do legado realista, sem chegar ao modelo da pura transposição ${ }^{13}$. É importante salientar que apesar de Flávia Paula Carvalho classificar os autores regionalistas que analisa como pré-modernistas, ela considera que, em sua maior parte, esses autores são tradicionalmente incluídos no realismo, como faz Alfredo Bosi ${ }^{14}$.

Diante dessas duas posições, acredito que Valdomiro Silveira se insere no realismo/ naturalismo, não em função de seu regionalismo apresentar uma grande identificação com o

\footnotetext{
9 BOSI, Alfredo. "Introdução: O Pré-Modernismo". In: __. A literatura brasileira; o Pré-Modernismo. São Paulo: Cultrix, 1973. v. 5, p. 11, apud DIAS, Carmen Lydia de Souza. Paixão de raiz: Valdomiro Silveira e o regionalismo. São Paulo: Ática, 1984. p. 12-13.

${ }^{10}$ DIAS, Carmen Lydia de Souza. Op. cit., p. 13.

${ }^{11}$ Em relação às questões ideológicas suscitadas a partir do Movimento Modernista de 1922, ver LAFETÁ, João Luiz. 1930: a crítica e o Modernismo. São Paulo: Duas Cidades; Ed. 34, 2000.

${ }^{12}$ DIAS, Carmen Lydia de Souza. Op. cit., p. 13.

${ }^{13}$ CARVALHO, Flávia Paula. Op. cit., p. 14.

${ }^{14}$ CARVALHO, Flávia Paula. Op. cit., p. 15.
} 
caipira e com a paisagem, assim como uma maior fidelidade nos retratos, mas em função do grau de consciência em relação a problemas sociais e econômicos que envolvem o caipira. Comparando este escritor com os demais, tradicionalmente inseridos no pré-modernismo, tais como Euclides da Cunha e Lima Barreto, percebe-se que Valdomiro não se aprofundou nas questões sociais que envolvem seu objeto de projeção literária, no sentido de revelar, conscientizar e até mesmo denunciar ao leitor aquilo que provocava a exclusão social do caipira, isto é, a falta de "formas permanentes de atividades econômicas - à exceção de alguma agricultura de subsistência"15, que, infelizmente, produziu "uma massa de população totalmente desarticulada, trabalhando com baixíssima produtividade numa agricultura de subsistência"16 que passou a viver em comunidades ${ }^{17}$ onde os diversos pequenos grupos de agricultores ficaram isolados uns dos outros. Observamos nas comunidades caipiras de hoje o problema da falta de atividades econômicas permanentes, aliado à crescente e excludente mecanização da lavoura, desagregando essas comunidades e levando boa parte de seus membros ao êxodo rural.

Além do debate em torno da classificação de Valdomiro Silveira dentro de uma determinada escola literária, o conjunto de sua obra suscita, sobretudo, outras duas visões críticas diferentes sobre ele: a positiva (representada por Alfredo Bosi) e a restritiva (representada por Antonio Candido).

A perspectiva crítica de Alfredo Bosi parte do princípio de que Valdomiro Silveira, em sua postura regionalista enquanto um programa de valorização do elemento humano tipicamente regional (o caipira), serve como um indício de renovação na prosa ficcional brasileira do final do século xix, na medida em que procura transcrever fielmente o falar caipira de seu tempo, assim como tenta projetar na literatura sua visão de mundo sobre a realidade que o cercava naquele momento histórico. Preferimos a idéia de "projeção literária", em substituição à noção de "representação literária" (associada ao conceito crítico da categoria da representação), pois esta atualmente se encontra em crise na crítica de literatura por partir do princípio de que a realidade é definida e compreensível, quando, a partir de 1930, para alguns críticos como Walter Benjamin ${ }^{18}$, a literatura produz uma imagem daquilo

\footnotetext{
${ }^{15}$ FURTADO, Celso. "Regressão econômica e expansão da área de subsistência". In: Formação econômica do Brasil. 24a ed. São Paulo: Editora Nacional, 1991. p. 84.

${ }^{16}$ FURTADO, Celso. Op. cit., p. 86.

${ }^{17}$ As comunidades caboclas paulistas constituíram os bairros rurais, conforme é explicado em QUEIROZ, Maria Isaura Pereira de. Bairros rurais paulistas. São Paulo: Duas Cidades, 1973.

${ }^{18}$ BENJAMIN, Walter. A modernidade e os modernos. Rio de Janeiro: Tempo Brasileiro, 1975.
} 
que acredita ser o real, assim como, segundo Fredric Jameson ${ }^{19}$, todo conhecimento decorrente da observação da realidade é provisório e parcial.

A perspectiva de Antonio Candido concentra-se nos aspectos ideológicos da obra de Valdomiro Silveira, procurando associá-la ao contexto histórico-social da sociedade rural do final do século xix, período em que o escritor estava impregnado dos vícios literários e ideológicos típicos daquela época (tais como as idéias do Determinismo, do Evolucionismo e do Positivismo, tão em voga no período do realismo/ naturalismo), assim como envolto na suspeita de reificação de seu foco principal de, digamos assim, projeção literária, a partir do que concebia como sendo o real, isto é, o caipira.

Valdomiro Silveira, enquanto um sujeito formado dentro do universo positivista e evolucionista, não poderia deixar de carregar dentro de si algumas marcas dessa formação. Isso explica, em certo modo, como o escritor exibe, de modo curioso, os elementos regionalistas presentes em sua produção ficcional que tem como objetivo projetar literariamente (ao invés de usarmos a expressão representar literariamente) o caipira. Em relação à crítica de Antonio Candido sobre o conjunto da obra de Valdomiro Silveira, transcrevo um parágrafo do livro Paixão de raiz, de Carmen Lydia de Souza Dias, que chama a atenção para a importância atribuída por Antonio Candido ao componente ideológico na análise da obra do escritor:

\footnotetext{
"O ponto negativo da crítica, representado por Antonio Candido, não obstante reconhecer também em Valdomiro um mestre que sabe versar com desembaraço o dialeto dos caboclos, põe em questão o teor ideológico da obra. Apesar da sua ciência no uso do dialeto, a obra de Valdomiro Silveira, recheada de regionalismos, não resiste à tentação de exibi-los como objeto curioso, arrastando nessa exibição aquele que constitui o seu cerne: o homem caipira. Resultaria daí, segundo Antonio Candido, uma idéia deformada, e mesmo perniciosa, de quem é e de como vive o caboclo, ${ }^{20}$.
}

Diante das visões positiva e restritiva da obra de Valdomiro Silveira, acredito numa mescla de ambas para melhor interpretá-la. As duas visões, a meu ver, são complementares. Enquanto a positiva enfatiza o trabalho lingüístico e humanista do escritor (no sentido deste dar voz a um sujeito que, à época de sua produção literária, era marginalizado socialmente), a restritiva questiona a qualidade ideológica de sua obra. Considero que a inclusão do questionamento em torno da ideologia na obra do autor, feita por Antonio Candido, é de suma

\footnotetext{
${ }^{19}$ JAMESON, Fredric. O inconsciente político. São Paulo: Ática, 1992.

${ }^{20}$ DIAS, Carmen Lydia de Souza. Op. cit., p. 152.
} 
importância. É através de um viés ideológico que o autor constrói, expressa e projeta literariamente o caipira, imprimindo sua visão política e social de mundo na obra que produziu e, conseqüentemente, sua visão subjetiva a respeito de quem é e como vive seu objeto de projeção literária.

Juntamente com a questão ideológica, no que diz respeito ao regionalismo "de programa" enquanto uma corrente literária que procurou projetar a realidade do homem e da vida no sertão, pode-se observar que, ao longo da década de 1930, os autores representativos da corrente regionalista (Valdomiro Silveira e Simões Lopes Neto, entre outros) passaram a problematizar com mais intensidade as questões políticas e sociais presentes na sociedade brasileira e, também, sul-americana.

\section{Um pouco de História}

Valdomiro Silveira começa a produzir seus textos na virada da Monarquia para a República (cuja proclamação foi em 1889). Nessa época, a sociedade brasileira deixava de viver sob a tutela de um rei (considerado pela maioria do povo brasileiro um verdadeiro pai) passando para a tutela de um presidente (que, em um primeiro momento, foi um militar, o marechal Deodoro da Fonseca).

A República trouxe para a vida política, econômica e social uma nova ordem. A Igreja se separou do Estado, a oligarquia agrária (representada, principalmente, pelos grandes cafeicultores) se uniu à classe média (representada pelos militares) e à burguesia urbana (representada pelos incipientes industriais e comerciantes).

Dentro do contexto histórico determinado pela República, surge um grupo social que passa a viver à margem dos latifúndios: o dos caipiras ${ }^{21}$. População que foi fruto de uma grande miscigenação racial entre o branco, o índio e o negro, e que se mantém graças à agricultura de subsistência no interior de grandes fazendas, os caipiras começam a receber a atenção de alguns escritores que procuram valorizar e retratar literariamente sua marginal realidade (incrementando o regionalismo) a partir da segunda metade do século xix. Entre esses escritores se encontra Valdomiro Silveira.

\footnotetext{
${ }^{21}$ A respeito da formação e constituição econômica do grupo social dos caipiras na sociedade rural brasileira em fins do século xviii, consultar FURTADO, Celso. "Regressão econômica e expansão da área de subsistência". In: _. Formação econômica do Brasil. 24a ed. São Paulo: Cia. Editora Nacional, 1991. p. 84-86.
} 


\section{Critérios da edição}

Ao analisar os contos de Mucufos, observei que o escritor fez uso constante do coloquialismo em sua modalidade rural. Nos textos aparecem muitos arcaísmos (tais como: “ansim", "inté", "a mó’ que", entre outros) e regionalismos (tais como: "fadista", "tombador", "tucuruva", entre outros), não sendo fácil muitas vezes distinguir uns dos outros. Carmen Lydia de Souza Dias em sua pesquisa de 1976-1980, que resultou na obra Paixão de raiz: Valdomiro Silveira e o regionalismo, com base nas idéias de Amadeu Amaral ${ }^{22}$, fez uso do conceito de dialeto para designar o modo de falar das personagens caipiras presentes nos contos. Optei pelo uso da expressão falar caipira ao invés de dialeto caipira por considerar o modo de falar dos caboclos, pesquisado por Valdomiro Silveira numa extensão territorial que abarca boa parte do interior de São Paulo, sul de Minas Gerais e um trecho do Rio de Janeiro, uma variedade lingüística regional.

Nos dias de hoje, principalmente nos noticiários da União Européia, onde a questão das variedades lingüísticas é muito séria, não se fala mais em dialeto, segundo o filólogo Bruno Fregni Bassetto ${ }^{23}$. Tudo para os europeus é língua. Isto acontece porque a distinção entre os conceitos de língua e dialeto, na prática, não funciona, pois é muito difícil afirmar com segurança onde termina uma variedade lingüística e começa outra.

O conceito de dialeto não comporta apenas uma forma de interpretação. Cada autor lhe dá um significado próprio e o que gera uma grande confusão. O que podemos realmente observar são variedades lingüísticas regionais no vocabulário e em alguns aspectos fonéticos. Mário Marroquim chega a falar em "Língua do Nordeste", ao tratar de pequenas variedades lingüísticas regionais ${ }^{24}$. Amadeu Amaral usa a expressão dialeto caipira ${ }^{25}$.

Diante da controvérsia acima exposta e considerando que o termo dialeto está mais relacionado com a definição de língua, em um sentido gramatical mais amplo, reafirmo a preferência pela expressão falar caipira (adotando a posição de Ataliba Teixeira de Castilho ${ }^{26}$ )

\footnotetext{
${ }^{22}$ AMARAL, Amadeu. O dialeto caipira. São Paulo: Anhembi, 1955.

${ }^{23}$ As posições do filólogo no campo da dialetologia aparecem em BASSETTO, B. F. As Minorias Lingüísticas da România. Rio de Janeiro: Philologus, 2000, v. VI, p. 99-112, e Situação Atual das Línguas Românicas. Rio de Janeiro: Anais do II Congresso Nacional de Lingüística e Filologia, 1999, v. II, p. 61-67. Trata-se, como se pode observar, de dois artigos publicados em periódicos.

${ }^{24}$ MARROQUIM, Mário. A Língua do Nordeste: Alagoas e Pernambuco. $2^{\mathrm{a}}$ ed. São Paulo: Companhia Editora Nacional, 1945.

${ }^{25}$ AMARAL, Amadeu. Op. cit., p. 42.

${ }^{26}$ A posição de Ataliba Teixeira de Castilho a propósito da terminologia "falar - dialeto" está exposta, em boa medida, nos seguintes textos de sua autoria: Rumos da Dialetologia Portuguesa. Alfa, 18/ 19, 1973. p. 115-153, Variação dialetal e ensino institucionalizado da Língua Portuguesa. Cadernos de Estudos Lingüísticos 1, 1978.
} 
por estar mais próxima do conceito de variedade lingüística regional, entendida enquanto um desvio da norma padrão culta de uma determinada língua. Essa norma padrão é usada por comunidades de falantes, basicamente em ambientes urbanos, que têm acesso a um grau mais elevado de escolaridade. Trata-se, portanto, de comunidades urbanas letradas com um razoável nível educacional.

O conceito de dialeto, por se aproximar mais do conceito de língua, nos parece impróprio para se referir ao modo de falar dos caipiras, que chega a ser mais uma derivação do que propriamente uma língua. $\mathrm{O}$ dialeto se distingue da variedade lingüística regional por apresentar diferenças acentuadas do ponto de vista sintático. É praticamente uma outra língua. A variedade não apresenta muitas diferenças, a não ser no modo peculiar como os falantes a usam.

A variedade regional está relacionada com o falar de um determinado grupo social que vive à margem da educação formal. Isso não significa necessariamente que os falantes de uma certa variedade regional sejam iletrados. Simplesmente são pessoas que vivem em regiões não-urbanas, tais como as zonas rurais. Em alguns casos, os falantes da variedade regional são iletrados, pois não tiveram acesso à escola. O conto "Seo doutor" nos serve como um bom exemplo da diferença entre o mundo letrado, representado pela personagem Valdóro, alter ego de Valdomiro Silveira, que foi à cidade cursar Direito e, portanto, adquirir formação altamente letrada, e o mundo não-letrado, representado pelos caboclos que viviam na fazenda. Valdóro dirigia-se aos caipiras ora com o falar próprio destes, ora com um coloquialismo culto.

Antonio Candido, no programa Expresso Brasil, transmitido pela TV Cultura às 12:30 do dia 13 de maio do corrente ano, ao falar sobre a cultura caipira que pesquisou durante alguns anos e que resultou em seu livro Os parceiros do Rio Bonito, explicou que determinadas palavras que consideramos como sendo arcaísmos nos dias de hoje, tais como "despois" e "pregunta", eram correntes e consideradas cultas no falar urbano ao longo do século xvii.

Atualmente verifica-se uma mistura de falares na cidade grande. Palavras e expressões que eram usadas no ambiente rural invadiram a cidade com o êxodo de muitos caipiras.

p. 18-25 e Variedades conversacionais. Boletim da ABRALIN 5, 1983. p. 40-53. Também se pode encontrar referências à terminologia em CASTILHO, Ataliba T. de et alii, orgs. Gramática do Português Culto Falado no Brasil: Construção do texto falado. Campinas: Editora da UNICAMP, 2006. v. 1. 
Muitas vezes observamos pessoas da cidade dizendo "eta nóis" e "num carece”, típicas do sertão.

Inicialmente, transcrevi os vinte e quatro contos de Mucufos tomando como base o apógrafo de Carmen Lydia de Souza Dias, a versão de que eu dispunha antes da doação dos manuscritos por parte da Família Valdomiro Silveira.

Às informações presentes no apógrafo foram acrescidos os dados colhidos do confronto com os manuscritos e datiloscritos contidos nas pastas Mucufos e Originaes manuscriptos de Papae (preciosíssimos), doadas ao IEB/ USP.

O confronto entre o apógrafo de CLSD e os textos encontrados nas pastas acima referidas, a partir da doação da família do escritor ao IEB/ USP, proporcionou um outro direcionamento ao preparo da edição. Isto porque foram conhecidas informações que não constavam do apógrafo. Estas informações dizem respeito à data, local de escritura, quantas versões foram escritas e que tipo de versões são (se em autógrafo ou em datiloscrito). Descobri que havia duas versões, uma em cada pasta, dos contos "Amaldiçoada", "Quebrante", "Soberbia”, "Soneira brava", "Reis", "Capiango", "Forte teima!" e "Paixão de raiz". Juntamente com as descobertas, pude saber de dois dados que não constam no apógrafo: o periódico ao qual "Capiango" foi enviado (O Paiz) e a data do envio (2 de agosto de 1899). O conhecimento destes dados só foi possível graças ao encontro e à doação ao IEB/ USP das pastas Mucufos e Originaes manuscriptos de Papae (preciosíssimos).

A pasta Originaes manuscriptos de Papae (preciosíssimos) foi organizada por D. Júnia Silveira Mendes Gonçalves, filha do escritor. O título foi escrito em letra cursiva da própria D. Júnia. Para dar início à organização dos documentos, cada conto de cada uma das pastas foi colocado dentro de uma folha completa de papel almaço branco sem pauta, e sobre ela foi grafado o título dele, assim como o da obra à qual ele pertence. Este trabalho ainda está sendo feito no momento e conta com a preciosa ajuda da professora Camila Koshiba, mestre em História pela USP e estudiosa da cultura caipira.

A pasta Mucufos foi organizada por Valdomiro Silveira, que escreveu o título na capa com letra de fôrma.

A transcrição com base no apógrafo de CLSD foi feita tomando-se o cuidado de não alterar os regionalismos e os arcaísmos presentes nos contos, pois estas formas de escrita indicam muitas vezes pronúncias e certos problemas gramaticais de época, concernentes ao campo da fonologia e da ortografia, por exemplo. Pensei realizar a 
atualização ortográfica pela norma vigente, em uma primeira etapa da pesquisa, seguida de uma segunda, na qual pesei melhor as características da ortografia utilizada por Valdomiro Silveira, a qual privilegiava os aspectos fonológicos.

Mantive, portanto, os acentos agudos de formas como "pérca" e "p'r amór de" para marcar a sonoridade. Isto porque estas formas não se ligam a questões de ortografia, mas sim ao campo da fonologia. Como a proposta de Valdomiro Silveira era registrar o falar caipira tal qual se apresentava em sua época, os acentos se justificam em função da pronúncia mais intensa de certas sílabas por parte dos caipiras.

Alterei as formas "p'ra”, "p'r'a” e "p'r'o", tanto no singular quanto no plural, para "pra” (nos dois primeiros casos) e "pro", porque se tratam de arcaísmos de época que foram modificados pelas normas ortográficas ao longo dos anos. Não mudei a forma "p'r", arcaísmo de forma com o sentido de "por", porque aparece muitas vezes ao lado de "amór de", constituindo-se numa locução arcaica típica do falar caipira. Se alterasse toda a locução para "por amor de", haveria uma perda significativa de expressividade e o falar caipira, onde a locução se insere, soaria um tanto quanto artificial e destituído de vivacidade e realismo. Por não alterar o "p'r" que compõe a locução arcaica "p’r amór de", optei também por não alterálo quando aparece fora dessa locução, para manter uma certa padronização na transcrição.

$\mathrm{O}$ uso de alguns ditados populares em alguns contos, tais como "quem fala paga" (em "João Maçarico") e "meu dito, meu feito" (em "Soneira brava"), além de reforçar o trabalho cuidadoso de recolhimento de expressões populares e do registro delas na escrita, num esforço digno de um genuíno folclorista (como também fizeram Mário de Andrade e João Guimarães Rosa, com maestria), revela alguns elementos da mentalidade caipira da época, como a crença de que as palavras proferidas por uma pessoa têm alto preço na vida e de que aquilo que é dito (e previsto), muitas vezes acaba acontecendo na realidade.

A pesquisa constituiu-se basicamente de duas vertentes: o preparo da edição e as notas de rodapé.

O preparo da edição consistiu na transcrição e no estabelecimento dos textos de Mucufos, coletânea de vinte e quatro contos inéditos em livro, adotando a atualização ortográfica pela norma vigente, respeitando, porém, a pontuação original, por se tratar de questão de estilo. A metodologia da edição levou em conta manter os arcaísmos de forma e de sentido, os regionalismos e a estrutura das frases. Para tanto, adotei, como texto base, o apógrafo que foi completado com as versões dos contos publicados no periódico $O$ Estado de 
S. Paulo. Fui até o Arquivo do Estado em setembro de 2006 e consegui os microfilmes dos seguintes contos (publicados em O Estado de S. Paulo): "Somneira braba" (publicado em 19/01/1902), "Forte teima!" (01/02/1902), “Amaldiçoada" (10/02/1902), "Paixão de raiz" (11/12/1902), “Castigo do céu" (30/12/1902), “Grande amor!" (18/01/1903) e "Pazes" (15/10/1904). Aos contos publicados em outros periódicos, tais como Diário da Tarde (SP), Diário Popular (SP), Correio Paulistano (SP), O Repórter (SP), A Bruxa (RJ), A Gazeta de Notícias (RJ) e $O$ Paiz (RJ), não consegui ter acesso.

Desta forma, o caminho para a publicação de Mucufos foi este, tomando por base o apógrafo de CLSD:

1) busca dos manuscritos dos contos no Fundo Valdomiro Silveira;

2) separação das versões;

3) busca dos textos, os quais as notas de rodapé de VS sinalizam como publicados nos periódicos já referidos;

4) confronto das versões presentes nos periódicos com a versão no apógrafo de CLSD;

5) confronto com as versões nos manuscritos VS, no FVS, no IEB/ USP, feita a análise desses manuscritos;

6) estabelecimento do presente texto, considerando correções ao texto do apógrafo e ao dos periódicos, no caso de incompreensão de vocábulos existentes nos manuscritos na documentação doada ao IEB/ USP pela família do escritor. Este se constituiu no segundo confronto com os textos de Valdomiro Silveira;

7) preparação das notas da edição.

Após a colação e o estabelecimento do texto, incrementei as notas de rodapé da pesquisa com dados filológicos e geográficos a respeito de algumas expressões regionalistas presentes nos contos. Assim, pude mapear o uso de certos regionalismos.

Por intermédio do mapeamento, pude compreender o sentido dos regionalismos no mundo caboclo. Isto implica em dizer que acredito haver uma relação direta e dialética entre as palavras usadas pelos caipiras e a natureza ao seu redor. As palavras decifram o mundo natural e o mundo natural ajuda a entender o sentido das palavras.

A pesquisa no Arquivo Valdomiro Silveira do IEB/ USP colocou-me em contato com um acervo riquíssimo da produção literária do escritor. Em se tratando dos contos que 
compõem Mucufos, encontrei nas pastas Mucufos e Originaes manuscrptos de Papae (preciosíssimos) 12 e 13 contos respectivamente. Alguns títulos se repetem, tais como "Maldiçoada", "Somneira braba", "Forte teima!", "Quebrante”, "Soberbia", "Capiango", "Reis" e "Paixão de raiz". Em Originaes maunuscriptos de Papae (preciocíssimos), à exceção de "Maldiçoada", os outros contos correspondem à sua primeira versão. Pude encontrar algumas diferenças entre as versões, implicando até mesmo o desfecho da estória, como no caso de "Maldiçoada", que no apógrafo CLSD possui um final diferente daquele da primeira versão.

Para um bom trabalho de transcrição crítica e análise literária, a análise documentária dos contos é de grande utilidade, na medida em que situa os textos dentro de um certo contexto histórico (com menção a data e local da escritura) e nos fornece, através da menção aos recursos técnicos (tais como o tipo de papel e se o texto foi escrito a lápis ou a tinta) ligados ao ato de escrever, elementos extratextuais que acabam se relacionando intimamente e, porque não afirmar, dialeticamente, com a forma e o conteúdo da produção literária analisada.

Levando-se muito em conta a relação íntima entre os aspectos externos e internos da obra literária, ganha em importância o trabalho em torno de uma edição anotada de Mucufos. Ela proporciona, em primeiro lugar, o resgate da memória de Valdomiro Silveira, escritor esquecido pela crítica atual, através de uma parcela da produção artística do escritor, inédita em volume. Em segundo lugar, por intermédio das notas da edição, dá-se a conhecer os aspectos externos, que contribuem em larga medida para a análise histórico-literária.

\section{Os aspectos lingüísticos em Mucufos}

No que concerne aos aspectos lingüísticos, o contato com as formas arcaicas e regionais do falar caipira abre portas para um mundo que possui linguagem própria, repleta de registros de oralidade que nos remetem a uma cultura singular, com regras de conduta próprias. Afora sua degradação ao longo dos tempos, esta cultura, levada às cidades principalmente pelo êxodo rural, ainda continua viva no falar e no coração de muitos citadinos que descendem ou que sofreram influência dos caipiras. Haja vista as festas juninas das igrejas e escolas, recheadas de iguarias típicas da culinária cabocla. Quanto ao sertão propriamente dito, a cultura de lá também sobrevive, mesmo com a mecanização acentuada da lavoura, com a transformação do espaço rural em função de interesses econômicos 
desenfreados e da violência, provocada em larga escala pela exclusão social a qual os sertanejos são forçados a aceitar, por parte dos grandes latifundiários. E esta situação produz reações muitas vezes nada pacíficas por parte dos "mucufos", ao contrário do que pensam aqueles que querem considerar o caipira um sujeito passivo, cordial e preguiçoso.

É importante salientar o grande experimentalismo lingüístico presente nos contos de Mucufos. Esse experimentalismo é fruto de uma longa convivência com os caipiras nas cidades por onde Valdomiro Silveira passou, principalmente em Casa Branca e Santa Cruz do Rio Pardo, onde exerceu a promotoria pública. Nessas cidades, Valdomiro participou de pescarias, caçadas e festas típicas da cultura sertaneja. Entre os caipiras, ganhou até mesmo um apelido: Valdóro da Soledade. Seu envolvimento com o modo de vida caboclo foi tão intenso que chegou a anotar expressões e palavras ditas pelos caboclos e que, mais tarde, tornaram-se matéria de seus contos. É o que observa Júnia Silveira Gonçalves ao transcrever uma dessas anotações do pai: "'deu um tiro na arve, que 'tava entabuada de pombas' (apinhada, cheia) - João Bento: descendo o rio Pardo, Santa Cruz do Rio Pardo, 9-51895.",27.

Os aspectos do realismo/ naturalismo na obra

Concomitantemente à questão do registro do falar caipira, Valdomiro preocupou-se bastante com o estudo das aves e das plantas que encontrava sertão afora, e não deixou de colocar em seus textos vários nomes de ambos os seres. Este espírito científico justifica-se na medida em que desejava ser o mais fiel possível ao ambiente em que se locomovia, imprimindo em seus textos uma boa dose de realismo. Trata-se de nomes que não conhecemos na cidade, visto que os habitantes se mostram mais preocupados em construir casas e edifícios do que plantar árvores (tais como os andaaçus, as arindiúvas e os catiguás), e atrair diversas espécies de pássaros (tais como os urutaus, os xintãs e os sabiás-unas, somente para ficar em alguns exemplos registrados pelo escritor).

Valdomiro Silveira foi um dos contistas do começo do século xx em cuja produção "a matéria rural é tomada a sério, isto é, assumida nos seus precisos contornos físicos e sociais dentro de uma concepção mimética de prosa" ${ }^{28}$.

\footnotetext{
${ }^{27}$ GONÇALVES, Júnia Silveira. "Notas Biográficas sobre Valdomiro Silveira". In: SILVEIRA, Valdomiro. Mixuangos. ${ }^{\mathrm{a}}$ ed. Rio de Janeiro: Civilização Brasileira; Brasília, INL, 1975. p. XI.

${ }^{28}$ BOSI, Alfredo. História concisa da literatura brasileira. $3^{a}$ ed. São Paulo: Cultrix, 1992. p. 232.
} 
A “concepção mimética de prosa”, referida por Alfredo Bosi, em boa medida traduz a preocupação do escritor em registrar literariamente as palavras e expressões arcaicas e regionais exatamente as como ouvia dos caipiras com quem conversava em suas andanças pelo interior de São Paulo em sua época. Não há na prosa de Valdomiro Silveira uma criação lexical (através do uso de neologismos) em cima da matéria bruta que era a linguagem cabocla ouvida e registrada em papéis. Neste ponto, sua produção difere daquela de outro grande ouvinte e registrador de expressões sertanejas, que é João Guimarães Rosa. Este, a partir do que ouvia e registrava, criou palavras novas utilizando praticamente todo o arsenal de recursos da gramática e da linguagem poética, tais como: deslocamentos de sintaxe, vocabulário inabitual, arcaico ou neológico, aliterações, rimas internas, metáforas, metonímias, entre outros. Para Alfredo Bosi, “Guimarães Rosa só inventou depois de ter feito o inventário dos processos da língua" ${ }^{29}$. Segundo Ana Cristina Cesar:

"É difícil deixar de pensar em Guimarães Rosa quando se lê Valdomiro Silveira. Escritor do interior paulista nascido em 1873, Valdomiro também vai buscar material para seus contos (que estão sendo relançados pela Civilização Brasileira) nas figuras do sertão, nos grupos e tipos locais, e ao mesmo tempo incorporar à sua linguagem regionalismos, aforismos tradicionais e umas primeiras ousadias de estilo com base regionalista" 30 .

No mesmo ensaio, a poeta e crítica literária faz referência a Péricles Eugênio da Silva Ramos, cujo prefácio a Nas serras e nas furnas procura provar com datas e locais de publicação o pioneirismo de Valdomiro Silveira, na publicação, na imprensa, de contos regionalistas. Porém Ana Cristina Cesar não considera o debate em torno do pioneirismo de Valdomiro Silveira o ponto mais importante no regionalismo do escritor. Para ela, a questão mais importante é o sentido mais amplo do aparecimento do regionalismo e não a "origem individual" desta corrente literária. Questiona, assim, a expressão "pura intenção regionalista", usada por Péricles Eugênio da Silva Ramos, ao supor que essa "pura intenção" poderia ser, provavelmente, a de "retratar uma região sem intervenções ideológicas, a fim de "refletir" fielmente a vida do homem do sertão. Ora, nem Valdomiro, nem outros escritores regionalistas, nem tampouco Guimarães Rosa, "refletem" o homem do sertão ou a linguagem dele intervêm nesse reflexo tanto no plano ideológico quanto no plano do trabalho com a

\footnotetext{
${ }^{29}$ BOSI, Alfredo. História concisa da literatura brasileira. Op. cit., p. 486.

${ }^{30}$ CESAR, Ana Cristina. "Quatro posições para ler: Sentado". In: __. Escritos no Rio. Rio de Janeiro: Editora UFRJ/ Brasiliense, 1993. p. 36-37.
} 
linguagem. É nessa intervenção realizada pelo artista que reside o seu interesse literário, e não na fidelidade da "transposição" de uma determinada realidade para o literário"31.

\title{
A concepção de regionalismo de Antonio Candido
}

A concepção de regionalismo de Antonio Candido apresenta-se em boa medida na passagem abaixo:

\begin{abstract}
"A consciência do subdesenvolvimento é posterior à Segunda Guerra Mundial e se manifestou claramente a partir dos anos de 1950. Mas desde o decênio de 1930 tinha havido mudança de orientação, sobretudo na ficção regionalista, que pode ser tomada como termômetro, dadas a sua generalidade e persistência. Ela abandona, então, a amenidade e curiosidade, pressentindo ou percebendo o que havia de mascaramento no encanto pitoresco, ou no cavalheirismo ornamental, com que antes se abordava o homem rústico. Não é falso dizer que, sob este aspecto, o romance adquiriu uma força desmistificadora que precede a tomada de consciência dos economistas e políticos”32.
\end{abstract}

Este trecho reforça a idéia de que, ao longo da década de 1930, “a ficção regionalista foi evoluindo em termos de problematicidade, surgindo obras razoavelmente eficazes na desmistificação da realidade não só do Brasil como de outros países sul-americanos. Apresentou um progresso em relação às tentativas anteriores do regionalismo naturalista que pecava pelo fatalismo. Nessa perspectiva, o homem pobre é visto como refratário ao progresso, em virtude do seu próprio destino individual, ignorando-se o fator genético: a espoliação econômica, fruto do expansionismo capitalista" ${ }^{, 33}$.

De acordo com o contexto sócio-econômico descrito acima, pode-se afirmar que a ficção de Valdomiro Silveira, desde o final do século xix, representou um avanço em termos de consciência dos problemas sociais que envolviam o caipira. Porém essa consciência, a partir daquele momento histórico, não conseguiu, nesse caso, atingir um nível muito elevado, devido a certas idéias positivistas e evolucionistas que vigoravam na sociedade brasileira e que marcaram, de algum modo, o pensamento do autor. Por ter uma visão política liberal e burguesa, Valdomiro atinha-se a um ponto de vista reformista em relação às instituições políticas de seu tempo. De qualquer modo, sua ficção, ao procurar projetar uma visão bem próxima do que ele compreendia como sendo a realidade do mundo caipira, conseguiu ser fiel

\footnotetext{
${ }^{31}$ Op. cit., p. 37.

${ }^{32}$ CANDIDO, Antonio. "Literatura e subdesenvolvimento". In: Paulo: Ática, 1987. p. 142.

${ }^{33}$ DIAS, Carmen Lydia de Souza. Op. cit., p. 39-40. A educação pela noite e outros ensaios. São
} 
ao modo de falar do caboclo, assim como apontou vários problemas sócio-econômicos que envolviam seu objeto de projeção literária e que, mais tarde (no regionalismo ideologicamente mais consciente em relação aos problemas sociais, representado pela ficção de Graciliano Ramos e Guimarães Rosa, principalmente), seriam problematizados com mais profundidade na literatura brasileira.

\section{A contribuição da categoria do realismo, segundo Georg Lukács, nas análises dos contos}

Além do auxílio das idéias de Antonio Candido em relação ao regionalismo, para se compreender os contos de Valdomiro Silveira, não só de Mucufos, mas de todas as suas obras, dentro do contexto mais amplo de seu projeto literário, pode-se valer de alguns conceitos de Georg Lukács que se referem à projeção literária da realidade na ficção ${ }^{34}$. Um deles é a idéia do reflexo (enquanto categoria estética) para se entender literatura e realidade. De acordo com esta categoria, a literatura serve como um espelho que reflete a realidade social do jeito que ela se apresenta para o escritor. Essa idéia de espelhamento não deve se restringir à superfície das coisas. A literatura, nesse sentido, deve criar um reconhecimento profundo por parte do leitor dos problemas sociais e políticos. Neste ponto, chega-se ao eixo que transforma a História segundo Lukács: a consciência de classe. Segundo essa perspectiva, a obra literária serve como instrumento de conscientização de um leitor oprimido por um sistema político que o aliena e o transforma em uma máquina que reproduz mecanicamente tudo aquilo que é obrigada a fazer.

Se partirmos da idéia de que Silveira o é de fato um realista, pensamos, com Lukács, que a totalidade objetiva da realidade exerce um papel marcante na obra literária dele. Lukács acreditava que era possível entender o todo da experiência humana através da projeção de uma situação específica da realidade de um determinado objeto.

Outros conceitos lukacsianos a que se é possível recorrer para entender o conto de Valdomiro Silveira é o de particularidade, o de realismo e a idéia de "função social" da obra de arte dentro de uma estética marxista. Para comentar um pouco esses conceitos, pode-se valer da seguinte passagem de Paixão de raiz: Valdomiro Silveira e o regionalismo:

\footnotetext{
34 LUKÁCS, Georg. A teoria do romance: um ensaio histórico-filosófico sobre as formas da grande épica. Trad. José Marcos Mariani de Macedo. São Paulo: Duas Cidades; Ed. 34, 2000.
} 
“Ainda quanto ao papel do elemento de natureza filosófica chamado "particular", vemos que reaparecerá no plano da aplicação da filosofia à teoria da literatura em Lukács e em outros teóricos marxistas. Atuará com toda a força dinâmica que lhe atribui incessantemente aquele pensador: convertido em pressuposto, o conceito de particularidade como o "específico estético" enformará o conceito de realismo, absolutamente ligado à idéia de "função social" dentro da estética marxista.

O particular, formado de determinações precisas, capacita ao conhecimento, em termos universais. Entretanto, ele se erige tão-somente à custa da síntese das múltiplas experiências concretas do escritor. $\mathrm{Na}$ idéia de concretude, determinante essencial da indispensável concepção do mundo de cada autor, em termos de experiência humana e social, está contida, por sua vez, a idéia de realismo. O termo, que não significa aqui uma determinada maneira de escrever, nem uma rigidez de procedimentos estéticos, nem um determinado período histórico-literário, refere-se antes a uma estrutura que possibilite ou não impeça a expressão realista desses objetos. Ele, por sua vez, deriva de tendências, não de estilos, e provém das exigências existenciais do artista. Qualquer que seja a concepção do mundo, desde que o autor a possua, sua obra resultará numa representação adequada da realidade objetiva, ainda que variem muito os meios de expressão utilizados. Percebe-se, dentro da discussão em torno da rigidez da concepção lukacsiana de realismo, um ponto central: Lukács confia que a conduta literária de fidelidade ao real traz como consequiência inevitável a apreensão e a iluminação das contradições entre realidade objetiva e ideologia de uma dada época. A realidade do processo social só é visível na práxis, no conjunto dos atos e ações do homem. E dizer esta verdade é tarefa do realismo, demolidor dos mitos, dos preconceitos e do obscurantismo que garante a manutenção de uma ordem social injusta.

Com base nesse tema central que encarece uma possível eficácia da obra em termos de atuação social, pode-se pensar a possibilidade de análise dos contos regionais. Se é natural que as grandes obras de arte se constituam automaticamente como indicadoras do desenvolvimento dos processos sociais, também é compreensível que as obras menores, de caráter realista, carreguem, em sua pequenez, importantes elementos de caracterização da realidade de uma época",35.

Da passagem acima transcrita pode-se dizer que os conceitos lukacsianos se relacionam entre si para caracterizar ou construir uma determinada visão de realidade de uma certa época por parte de um escritor. O particular, que pode ser visto como sendo as características próprias de uma determinada região (o sertão paulista, por exemplo) e de um determinado tipo humano que vive nele (o caipira), é esteticamente construído partir da vivência concreta do escritor. No caso de Valdomiro Silveira, ele fez várias andanças pelo sertão paulista, visitou bairros rurais e conheceu de perto o modo de vida do caipira e seu modo próprio de falar. Tudo o que observou, anotou. Fazendo uso de suas anotações, ele compôs suas obras a partir de sua ótica marcada por uma visão liberal, burguesa e reformista,

\footnotetext{
${ }^{35}$ DIAS, Carmen Lydia de Souza. Op. cit., p. 45-46.
} 
onde aparece uma determinada visão da realidade humana e social com base no que observou com seus próprios olhos. Isso contém a idéia de realismo em suas obras, o que corresponde a uma determinada construção estética que possibilita a expressão realista (do ponto de vista do escritor) dos objetos que o autor procura projetar em suas obras. $\mathrm{O}$ realismo acima referido, por sua vez, está intimamente associado com os interesses particulares e existenciais do escritor. Assim, a obra do autor terá como resultado a projeção adequada da realidade objetiva que ele observa a partir de seu ponto de vista existencial.

A realidade objetiva projetada literariamente pelo autor, segundo Lukács, deve buscar e conhecer a ideologia dominante na época em que o ele escreve sua obra. Esse encontro, ainda segundo Lukács, deve revelar ao autor e ao seu público as contradições do processo social, promovendo a demolição dos mitos e preconceitos que sustentam uma ordem social injusta. A partir disso, Lukács elabora o conceito de "função social" da obra de arte que, para ele (e segundo a estética marxista), serviria como um instrumento de conscientização do proletariado em relação à exploração promovida pela ordem capitalista. Segundo esta visão de Lukács, a obra literária tem mais valor na medida em que produz um maior grau de eficácia em termos de ação social. De acordo com essa ótica lukacsiana, Carmen Lydia de Souza Dias propõe a reflexão sobre a possibilidade de analisarmos os contos regionais (de Valdomiro Silveira e de outros escritores regionalistas) independentemente da grandeza das obras literárias, em termos de possuírem elas maiores ou menores indicadores acerca do desenvolvimento dos processos sociais de uma determinada época e do caráter realista das mesmas. O que realmente importa nas obras literárias, sejam elas maiores ou menores, são os elementos de caracterização da realidade (segundo a visão de mundo de cada escritor) de uma determinada época, que estão contidos nelas.

Procurando transportar os conceitos lukacsianos acima descritos para os contos de Valdomiro Silveira, pode-se afirmar que, através da caracterização das personagens, das relações delas com o meio em que vivem, o narrador valdomiriano vai traçando um quadro social bem típico do sertão brasileiro e promove uma denúncia político-econômica da violência que envolve essa sociedade, no seio da família ou fora dela ("Capiango" e "Na rua do Bosque"). 


\section{$\underline{\text { A violência e seu tratamento estético }}$}

A aproximação do escritor culto Valdomiro Silveira do universo caipira, por meio da invenção de um narrador caboclo, denota uma certa consciência (mesmo que não seja profunda) dos problemas sociais que cercam o mundo rural desse mesmo caboclo. Um deles é o desnível entre as visões de mundo acerca do que seja o real por parte de quem vem de um ambiente urbano (o autor do conto) e de quem vem de um ambiente rural (o narrador). A narração feita por um sujeito inserido no ambiente rural, leva-nos a conhecer um meio social paternalista, autoritário e violento, regido por determinadas normas de conduta, um lugar onde a justiça oficial e instituída não chega e não é aplicada.

Em outros contos de Valdomiro Silveira, tais como "Cobra mandada" (em Leréias: histórias contadas por eles mesmos), aparece a violência ligada à questão da posse e uso de terras. Não aprofundarei o tema da violência devido aos limites desta pesquisa. Mas fica aqui o registro da presença deste aspecto na obra valdomiriana, a cargo de uma possível futura análise. Reconheço, também, que os aspectos da violência presentes em alguns contos de Mucufos podem ser bem mais desenvolvidos. Também fica aqui uma abertura para possíveis trabalhos futuros sobre o tema. Outros temas, tais como a relação entre o homem letrado e o iletrado (em "Seo doutor"), a configuração do mal (em "Amaldiçoada"), o mapeamento de um maior número de palavras e expressões regionalistas contidas nos contos de Mucufos, a análise dos "casos" presentes em alguns textos e a visão de Brasil de Valdomiro Silveira, depreendida da leitura dos textos, também podem ser aprofundados em outros trabalhos. Outro tópico a ser bem mais trabalhado é o do distanciamento entre narrador e personagens (se há maior ou menor incongruência entre eles e no que consiste esta incongruência) nos contos de Mucufos e, também, em outras obras de Valdomiro Silveira. Pode-se comparar este distanciamento presente nos textos de Valdomiro com o mesmo recurso existente nos textos de outros escritores regionalistas de seu tempo, tais como Coelho Neto, Simões Lopes Neto e Hugo de Carvalho Ramos, ou até mesmo de escritores de tempos mais recentes, que partiram da matéria regional e depois ampliaram seu foco temático, tais como Graciliano Ramos e Guimarães Rosa. Também se pode aprofundar o estudo do regionalismo (partindo-se, por exemplo, da concepção de Antonio Candido sobre o assunto) em relação à categoria do realismo (tomando por base a concepção de Georg Lukács) nos textos de Valdomiro Silveira.

A violência, acusada em oito contos de Mucufos, ora como tema (em "À hora da prisão", “Ânsia antiga" e "Forte teima!”), ora como motivo principal (“Amaldiçoada", "Bocó- 
de-mola", "Quebrante", "Capiango" e "Na rua do Bosque"), nos remete a uma passagem do livro Paixão de raiz, de Carmen Lydia de Souza Dias, onde a autora, referindo-se a algumas idéias em Homens livres na ordem escravocrata, de Maria Sylvia de Carvalho Franco, afirma:

"Na realidade, como observa Maria Sylvia, o comportamento violento está incorporado ao cotidiano caipira, presentes ou ausentes os "bons motivos" para isto. Eles existem já, determinando tal conduta, na raiz da organização sócio-econômica que, historicamente, veio marginalizando o caboclo pequeno sitiante, o posseiro e "menores", em termos de posse da terra",36.

A violência, aliás, é algo que viceja não só no meio rural, mas na sociedade brasileira como um todo. Sobre este assunto, discorre Marilena Chauí:

"É uma sociedade na qual as diferenças e assimetrias sociais e pessoais são imediatamente transformadas em desigualdades, e estas, em relações de hierarquia, mando e obediência (situação que vai da família ao Estado, atravessa as instituições públicas e privadas, permeia a cultura e as relações interpessoais). Os indivíduos se distribuem imediatamente em superiores e inferiores, ainda que alguém superior numa relação possa tornar-se inferior em outra, dependendo dos códigos de hieraquização que regem as relações sociais e pessoais. Todas as relações tomam a forma da dependência, da tutela, da concessão, da autoridade e do favor, fazendo da violência simbólica a regra da vida social e cultural. Violência tanto maior porque invisível sob o paternalismo e o clientelismo, considerados naturais e, por vezes, exaltados como qualidades positivas do "caráter nacional".

"É uma sociedade na qual as leis sempre foram armas para preservar privilégios e o melhor instrumento para a repressão e a opressão, jamais definindo direitos e deveres. No caso das camadas populares, os direitos são sempre apresentados como concessão e outorga feitas pelo Estado, dependendo da vontade pessoal ou do arbítrio do governante. Situação que é claramente reconhecida pelos trabalhadores quando afirmam que "a justiça só existe para os ricos", e que também faz parte de uma consciência social difusa, tal como se exprime num dito muito conhecido no país: "para os amigos, tudo; para os inimigos, a lei”. Como conseqüência, é uma sociedade na qual as leis sempre foram consideradas inúteis, inócuas, feitas para serem violadas, jamais transformadas ou contestadas. E onde a transgressão popular é violentamente reprimida e punida, enquanto a violação pelos grandes e poderosos sempre permanece impune" ${ }^{37}$.

\footnotetext{
${ }^{36}$ DIAS, Carmen Lydia de Souza. Op. cit., p. 118.

37 CHAUÍ, Marilena. Conformismo e resitência: aspectos da cultura popular no Brasil. $4^{\mathrm{a}}$ ed. São Paulo: Brasiliense, 1989. p. 54-55.
} 
Mais adiante, continua a filósofa:

"As disputas pela posse da terra cultivada ou cultivável são resolvidas pelas armas e pelos assassinatos clandestinos" ${ }^{\prime 3}$.

As passagens acima nos proporcionam compreender em boa medida como funciona a lógica da violência na sociedade brasileira. Transportando-a para o campo, que é o lugar onde se passam as estórias de Valdomiro Silveira, podemos observar o quanto a lei oficial é ineficaz diante do mandonismo dos coronéis. No sertão, são estes que de fato fazem as leis e são, mais do que respeitados pelos caboclos, temidos. Como exemplos de contos que tratam da violência por parte dos coronéis é o já citado "Cobra mandada", de Leréias, onde há uma disputa entre dois deles pela posse e limite de terras, e "Na rua do bosque", de Mucufos, onde um coronel, metido a valente, apela para ela para resguardar a honra de sua família.

A boa dose de realismo nos contos de Valdomiro Silveira, segundo a visão de Lukács, está na capacidade do autor de projetar e denunciar uma determinada relação de poder que culmina com a morte de uma das personagens envolvidas nesta relação. Como exemplo disto, posso citar o conto "Bocó-de-mola", onde um filho com problemas físicos e mentais, revoltado com as surras que recebia do pai, acaba por matá-lo.

Em relação à categoria do realismo utilizada por Lukács, é possível observar não só em Mucufos, mas em outras obras de Valdomiro Silveira, uma grande dose de empenho do escritor para narrar (de acordo com sua visão de mundo) uma certa realidade do sertão brasileiro, inclusive do ponto de vista lingüístico, na transcrição de modo bastante fiel ao falar caipira.. O outro aspecto da realidade do sertão, o da violência, envolvendo as relações sociais de parentesco ou associadas, principalmente, a disputas de homens por mulheres, à honra familiar e à posse e limite de terras, termina provocando a morte de pessoas diretamente envolvidas na questão, a mando de certos coronéis do sertão. E conseqüentemente, desencadeando a vingança.

\section{$\underline{\text { A visão de Brasil por parte de Valdomiro Silveira }}$}

A visão de Brasil por parte de Valdomiro Silveira, à época de sua produção literária, era a de um país onde as relações sociais eram marcadas pelo autoritarismo, que resultava muitas vezes em atos de violência entre parentes próximos, distantes e até mesmo entre

\footnotetext{
${ }^{38}$ Op. cit., p. 56.
} 
pessoas que não tinham nenhum grau de parentesco. No campo, quem detinha o poder eram os coronéis, que faziam suas próprias leis, passando por cima do poder público e mandando matar quem se atrevesse a questionar sua autoridade e ferisse seus interesses políticos e econômicos. No Brasil de hoje, ainda é possível observar as marcas da antiga sociedade paternalista e autoritária, que em muitos lugares ainda teima em se perpetuar pelo uso da violência, apesar de avanços sociais significativos, tais como o movimento feminista, que emancipou a mulher que outrora era um mero objeto nas mãos de seus maridos e patrões. Mas a violência ainda é a marca registrada de nossa sociedade, tanto no campo (onde ainda muitos trabalhadores rurais ainda são mortos) quanto na cidade (onde a exclusão social gerou um complexo sistema de criminalidade, com o surgimento e o ganho de espaço de perigosos traficantes de drogas nas grandes metrópoles brasileiras, muitos deles com o apoio corrupto de importantes setores do poder público que, sem o devido preparo e, também, sem muito empenho e vontade, deixa toda a população sem uma segurança de qualidade $)^{39}$.

No meio de tantos temas e motivos abordados em Mucufos, a violência merece grande destaque, na medida em que, produzida por forças autoritárias em um contexto de brutal concentração de renda e exclusão social, ainda hoje faz parte das relações sociais tanto no campo quanto na cidade. E Valdomiro Silveira, em certos contos de Mucufos, toca na questão da violência, ainda que de um modo ideologicamente pré-consciente (sem se aprofundar nas causas e consequiências da violência) e politicamente não-engajado. E esta realmente não era a proposta do escritor, mais preocupado em lançar luzes sobre os problemas sociais caboclos do que propor soluções a eles.

\section{$\underline{\text { A violência, ainda }}$}

A violência também é tratada na música brasileira, seja ela de raiz (que é a genuína música caipira, baseada nas modas de viola), seja ela da chamada MPB.

Na música caipira podemos pegar o exemplo do cateretê (que em São Paulo e Minas Gerais recebe a denominação de xiba e significa um tipo de "dança rural cantada, popular, provavelmente de origem portuguesa, mas cujo ritmo sofreu alterações por influência negra" $)^{40}$ "Chico Mineiro", gravado em 1963 e cantado pela dupla de irmãos Tonico

\footnotetext{
${ }^{39}$ Sobre a violência como instância que atravessa as relações sociais no Brasil, consultar WISNIK, José Miguel. "O famigerado". In: _. . Scripta/ Literatura. v. 5, n. 10. Belo Horizonte: PUC/ Minas, 2002.

${ }^{40}$ FERREIRA, Aurélio Buarque de Holanda. Novo dicionário Aurélio da Língua Portuguesa. $2^{\mathrm{a}}$ ed. rev. e ampl. Rio de Janeiro: Nova Fronteira, 1986. p. 369 e 1798.
} 
(falecido) e Tinoco. Esta música é de autoria de Tonico e Francisco Ribeiro. A música narra a última viagem de dois amigos íntimos, Chico Mineiro e seu patrão, que compravam e vendiam gado pelos sertões do Brasil afora. Nesta viagem, numa parada para apreciarem uma festa do Divino em Ouro Fino, no sertão de Goiás, "O Chico foi baleado/ Por um homem desconhecido" no meio daquela festa. A partir da tragédia, o amigo patrão deixou de comprar gado e, além de tudo, ficou sabendo, depois de ver o documento de Chico Mineiro, que ele era seu "legítimo irmão". Deixa a pergunta: quem era o desconhecido? Qual a razão desse tiro? Questões de terra ou encomenda de algum coronel?

$\mathrm{Na}$ MPB, observa-se a violência de um modo mais abrangente, extra-oficial e organizada, na canção "Podres poderes", de autoria de Caetano Veloso e gravada em 1984. A certa altura, o compositor baiano questiona: “Ou então cada paisano ou cada capataz/ Com sua burrice fará jorrar sangue demais/ Nos pantanais, nas cidades, caatingas/ E nos gerais?”. Trata-se da violência na cidade grande, exercida por "cada paisano" (o que podemos verificar, hoje em dia, com as milícias, financiadas muitas vezes por gente da alta sociedade, que agem nos morros cariocas, matando e cobrando propina de indefesos moradores de favelas), e no campo, praticada por "cada capataz" (os jagunços anônimos que matam os posseiros a mando dos grandes coronéis do sertão).

Uma canção da MPB que tematiza a violência institucionalizada que marcou um determinado período de nossa História (a época do regime militar a partir do golpe de 1964) e que nos deixou marcas profundas de autoritarismo em nossas relações sociais, é "Cálice", de autoria de Chico Buarque de Holanda e Gilberto Gil, composta em 1973, em pleno governo do general Emílio Garrastazu Médici, onde se perseguia e se torturava muitos opositores do regime militar. Nesta canção, observa-se o quanto o regime censurava e torturava fisicamente quem discordava dele as pessoas que queriam se expressar livremente. $O$ silêncio forçosamente imposto pela ditadura militar faz o eu-lírico da canção desabafar: "De que me serve ser filho da santa/ Melhor seria ser filho da outra/ Outra realidade menos morta/ Tanta mentira, tanta força bruta"). A expressão "força bruta" se refere à tortura física contra os opositores do regime militar.

Outro bom exemplo de canção da MPB que trabalha com o tema da violência é "Roda viva", composta em 1967. Nela, Chico Buarque de Holanda, trata da violência moral, não aquela que chega às vias de fato, isto é, que promove a morte ou a desintegração física de uma pessoa ou grupo social a mando de alguma autoridade instituída ou não, mas a violência 
psicológica, aquela que procura matar os valores morais de quem quer "nadar contra a corrente", sem compactuar com os modismos impostos pela mídia ("A gente vai contra a corrente/ Até não poder resistir/ Na volta do barco é que sente/ O quanto deixou de cumprir"). A violência, portanto, não é só física, mas também moral.

$\mathrm{Na}$ passagem do século xix para o $\mathrm{xx}$, dentro de um contexto de transformações sociais impulsionadas pela abolição da escravidão em 1888, a literatura regionalista começa a retratar o incipiente caipira, aquele sujeito que não era escravo, nem homem livre, pois vivia sob a tutela dos grandes fazendeiros.

Como sabemos, o espírito cientificista que tomou conta da sociedade brasileira daquela época, baseado no Positivismo, no Determinismo e no Evolucionismo, imbuiu Valdomiro Silveira da tarefa de retratar seu principal objeto de projeção literária, o caipira, de modo realista. Enquanto Monteiro Lobato (que depois de algum tempo mudou de opinião a respeito do caipira), com "Idéias de Jeca Tatu", projetava o caboclo de modo bem caricato e se referia a ele como sendo um sujeito indolente, Valdomiro Silveira, a partir de "Os caboclos", procurou retratar o caipira com espírito realista, apesar dos excessos de descrição, sentimentalismo e jocosidade que cometeu em certos contos, chegando em alguns momentos a tocar o terreno do caricatural.

O esforço de uma retratação literária fiel do caipira por parte do escritor começou a chamar a atenção para o problema social da marginalização deste indivíduo, que chegava a viver em regime de semi-escravidão, tutelado pelos grandes proprietários de terras. Isso, ao nosso ver, representou um grande avanço em relação à produção regionalista de seu tempo.

\section{A posição real de Valdomiro Silveira}

No que diz respeito ao conjunto de toda a produção literária de Valdomiro Silveira, cabe-nos afirmar que nem todos os escritores são geniais como Guimarães Rosa, mas pode-se reconhecer o esforço de quem procurou desenvolver uma nova proposta estética e estilística. E foi isso o que Valdomiro Silveira fez. Seu suposto pioneirismo na escritura de textos ambientados no espaço rural, assim como no registro da oralidade caipira, são notáveis e reconhecidos por pessoas da estirpe cultural de um Mário de Andrade, que o considerava um verdadeiro precursor do modernismo (principalmente no aspecto artístico do registro da linguagem oral de um determinado grupo social). 
Longe de ser um escritor medíocre, ao nosso ver, o que fez Valdomiro Silveira, se não foi uma arte maior, no sentido de ir além daquilo que vingava em termos culturais e ideológicos em seu tempo e espaço, como fez Guimarães Rosa, é uma grande arte. Uma grande arte de quem propôs uma nova visão sobre o trabalho literário, a partir de Valdomiro Silveira não mais pensado como sendo o culto purista das palavras eruditas do mundo dos homens letrados. Isso sem contar a nobre iniciativa humanista de dar voz a um "sojeito" marginalizado socialmente: o caipira.

Por tudo isso é que acredito que um resgate como o que me propus fazer, com o preparo da edição anotada de Mucufos, é altamente válido. Esta edição, além do mais, propicia um debate atualíssimo, tanto no ambiente urbano quanto no rural, a respeito das fronteiras entre a cultura erudita e a cultura popular. Presenciamos uma mistura entre o que consideramos erudito e o que julgamos popular. Um autêntico hibridismo cultural, fruto do contato entre elementos da cultura urbana e da cultura popular. Isso se deve, em boa medida, ao êxodo rural, que trouxe para a cidade um grande contingente de pessoas do campo em busca de melhores oportunidades de trabalho, assim como as migrações internas de gente de regiões pobres do Brasil, tal como o Nordeste, para regiões mais ricas, tal qual o Sudeste.

Com o resgate de uma obra inédita em volume como Mucufos, pretendo também contribuir para a manutenção e desenvolvimento do hibridismo cultural, na medida em que, ao analisar os contos da referida obra, observei um certo distanciamento (maior ou menor, dependendo do conto) entre narrador e personagens, o primeiro muitas vezes fazendo uso do coloquialismo culto e as segundas fazendo uso do falar caipira.

É um enorme prazer verificar, com o hibridismo cultural, que uma boa parcela dos valores culturais caboclos permanece viva, tanto no campo como na cidade, mesmo com a desagregação pela qual a cultura caipira passou, desde o início do século xx até os dias de hoje. Um bom exemplo disso é a valorização e a execução pública da música sertaneja (através de algumas duplas como Chitãozinho \& Xororó, Zezé di Camargo \& Luciano, entre outras), ainda que com significativas mudanças nos arranjos em comparação com a original música caipira de raiz, para satisfazer determinados interesses mercadológicos. 


\section{Bibliografia}

A Bíblia Sagrada. Trad. das Línguas Originais por João Ferreira de Almeida. 10ª impr. Deerfield: Editora Vida, 1996.

ALENCAR, José de. Iracema: lenda do Ceará. São Paulo: FTD, 1991. . O gaúcho. Rio de Janeiro: José Olympio, 1951. . O guarani. $11^{\text {a }}$ São Paulo: Ática, 1984. . O sertanejo. Rio de Janeiro: José Olympio, 1951.

AMARAL, Amadeu. O dialeto caipira. São Paulo: Anhembi, 1955.

ANDRADE, Mário de. Macunaíma o herói sem nenhum caráter. Texto revisto por Telê Porto Ancona Lopez. Belo Horizonte: Itatiaia, 1987. . "Pintor contista". In: __ O empalhador de passarinho. Belo Horizonte: Itatiaia, s.d. p. 60.

ARINOS, Afonso. Obra completa. Org. Afrânio Coutinho. Rio de Janeiro: MEC/ INL, 1969.

ASSIS, Machado de. Obra completa. Organizada por Afrânio Coutinho. Rio de Janeiro: Aguilar, 1962. v. 2/3.

BARRETO, Lima. Triste fim de Policarpo Quaresma. São Paulo: Brasiliense, 1978.

BASSETTO, B. F. As Minorias Lingüísticas da România. Rio de Janeiro: Philologus, 2000. v. VI, p. 99-112.

. Situação Atual das Línguas Românicas. Rio de Janeiro: Anais do II Congresso Nacional de Lingüística e Filologia, 1999. v. II, p. 61-67.

BATAILLE, Georges. A Literatura e o Mal. Porto Alegre: L\&PM Editores, 1990.

BAUDELAIRE, Charles. As Flores do Mal. Edição bilíngüe, tradução, introdução e notas de Ivan Junqueira. Rio de Janeiro: Nova Fronteira, 1985.

BECHARA, Evanildo. Moderna gramática portuguesa. 22a ed. São Paulo: Cia. Editora Nacional, 1977.

BENJAMIN, Walter. A modernidade e os modernos. Rio de Janeiro: Tempo Brasileiro, 1975. . Magia e técnica, arte e política: ensaios sobre literatura e história da cultura. Trad. Sérgio Paulo Rouanet. 7ª ed. São Paulo: Brasiliense, 1994. (Obras escolhidas; v. 1).

BOSI, Alfredo. História concisa da literatura brasileira. 3ª ed. São Paulo: Cultrix, 1992. 
. "Introdução: O Pré-Modernismo". In:

A literatura brasileira; o Pré-

Modernismo. São Paulo: Cultrix, 1973. v. 5, p. 11.

CANDIDO, Antonio. "A literatura e a formação do homem". In: . Textos de intervenção.

São Paulo: Duas Cidades; Ed. 34, 2002. p. 77-92. et alii. A personagem de ficção. São Paulo: Perspectiva, 1972. . “Caipiradas". In:__. Recortes. São Paulo: Cia. das Letras, 1993. p. 248251. . Formação da literatura brasileira. $4^{\mathrm{a}}$ ed. São Paulo: Martins, 1975. v. 1/2. . Literatura e sociedade. São Paulo: Nacional, 1965. . "Literatura e subdesenvolvimento". In: A educação pela noite e outros ensaios. São Paulo: Ática, 1987. p. 140-162.

. Noções de análise histórico-literária. São Paulo: Associação Editorial Humanitas, 2005. . Os parceiros do Rio Bonito. $2^{\mathrm{a}}$ ed. São Paulo: Duas Cidades, 1971.

CARVALHO, Flávia Paula. A natureza na literatura brasileira: regionalismo pré-modernista. São Paulo: Hucitec: Terceira Margem, 2005.

CASTILHO, Ataliba T. de et alii, orgs. Gramática do Português Culto Falado no Brasil: Construção do texto falado. Campinas: Editora da UNICAMP, 2006. v. 1. . Rumos da Dialetologia Portuguesa. Alfa, 18/19, 1973. p. 115-153. . Variação dialetal e ensino institucionalizado da Língua Portuguesa. Cadernos de Estudos Lingüísticos 10, 1978. p. 18-25. . Variedades conversacionais. Boletim da ABRALIN 5, 1983. p. 40-53.

CESAR, Ana Cristina. "Quatro posições para ler: Sentado". In: . Escritos no Rio. Rio de Janeiro: Editora UFRJ/ Brasiliense, 1993. p. 36-37.

CHAUÍ, Marilena. Conformismo e resistência: aspectos da cultura popular no Brasil. $4^{\mathrm{a}}$ ed. São Paulo: Brasiliense, 1989.

COELHO NETO. Obra Seleta. Vol. I [e único]. Rio de Janeiro: Editora José Aguilar Ltda., 1958.

CUNHA, Celso \& CINTRA, Luís F. Lindley. 2. ed./ 39. impr. Nova gramática do português contemporâneo. Rio de Janeiro: Nova Fronteira, 1999. . Que é um brasileirismo? Rio de Janeiro: Tempo Brasileiro, 1987. 
CUNHA, Euclides da. Os sertões. 2. ed. Ed. crít. de Walnice Nogueira Galvão. São Paulo: Ática, 2000.

D’ALÉSSIO, Lucrécia. Introdução ao regionalismo de Valdomiro Silveira. Tese de doutoramento apresentada à cadeira de Literatura Brasileira da Faculdade de Filosofia, Ciências e Letras “Sedes Sapientiae” da P.U.C.S.P., São Paulo, 1963.

DIAS, Carmen Lydia de Souza. Paixão de raiz: Valdomiro Silveira e o regionalismo. São Paulo: Ática, 1984.

ECO, Umberto. Obra aberta. Trad. Giovanni Cutolo. 2. ed. São Paulo: Perspectiva, 1971.

ÉLIS, Bernardo. "Valdomiro Silveira". In: GONÇALVES, Júnia Silveira, org. O mundo caboclo de Valdomiro Silveira. Rio de Janeiro: José Olympio/ SCET, CEC, MEC, 1974. p. 14.

FAUSTO, Boris, org. História geral da civilização brasileira. $2^{\mathrm{a}}$ ed. Rio de Janeiro/ São Paulo: Difel, 1978. t. 3, v. 2.

FERREIRA, Aurélio Buarque de Holanda. Novo dicionário Aurélio da Língua Portuguesa. $2^{\mathrm{a}}$ ed. ver. e ampl. Rio de Janeiro: Nova Fronteira, 1986.

FRANCO, Maria Sylvia de Carvalho. Homens livres na ordem escravocrata. São Paulo: Ática, 1974.

FURTADO, Celso. "Regressão econômica e expansão da área de subsistência". In:

Formação econômica do Brasil. 24ª ed. São Paulo: Cia. Editora Nacional, 1991. p. 84-86.

GIACOMOZZI, Gilio et alii. Em busca da real posição de Valdomiro Silveira na língua e literatura brasileira. Universidade de Taubaté, 1980.

GONÇALVES, Júnia Silveira. "Notas Biográficas sobre Valdomiro Silveira”. In: SILVEIRA, Valdomiro. O mundo caboclo de Valdomiro Silveira. Rio de Janeiro: José Olympio; São Paulo: Secretaria de Cultura, Esportes e Turismo; Brasília: Instituto Nacional do Livro, Ministério da Educação e Cultura, 1974. p. VII-XII. . "Notas Biográficas sobre Valdomiro Silveira". In: SILVEIRA, Valdomiro. Mixuangos. $2^{\text {a }}$ ed. Rio de Janeiro: Civilização Brasileira; Brasília, INL, 1975. p. IX-XVI. GUIMARÃES, Ruth. "Vida e obra de Valdomiro Silveira". In: GONÇALVES, Júnia Silveira, org. O mundo caboclo de Valdomiro Silveira. Rio de Janeiro, José Olympio/ SCET, CEC, MEC, 1974. p. 22.

HOLANDA, Chico Buarque de. "Cálice”, no vinil Chico Buarque, gravação Philips, 1978. 
"Roda viva", no vinil Chico Buarque de Hollanda - vol. 3, gravação RGE,

1968.

HOLANDA, Sérgio Buarque de. Raízes do Brasil. Rio de Janeiro: José Olympio, 1956.

JAMESON, Fredric. Marxismo e forma. São Paulo: Hucitec, 1985.

. O inconsciente político. São Paulo: Ática, 1992.

JOLLES, André. “O caso”. In: __. Formas simples. Trad. Álvaro Cabral. São Paulo: Cultrix, 1976. p. 145-166.

KAYSER, Wolfgang. Análise e interpretação da obra literária. $5^{\mathrm{a}}$ ed. portuguesa revista pela $12^{\mathrm{a}}$ alemã por Paulo Quintela. Coimbra: Arménio Amado, 1970. v. 1/2.

LAFETÁ, João Luiz. 1930: a crítica e o Modernismo. São Paulo: Duas Cidades; Ed. 34, 2000.

LIMA, Luiz Costa. Teoria da literatura em suas fontes. $2^{\text {a }}$ ed. rev. e ampl. Rio de Janeiro: Francisco Alves, 1983. v. 1/2.

LIMA, Rossini Tavares de. "Folclore do Brasil na obra de Valdomiro Silveira". In: SILVEIRA, Valdomiro. Leréias: histórias contadas por eles mesmos. $2^{\mathrm{a}}$ ed. Rio de Janeiro, Civilização Brasileira/ INL-MEC, 1975, p. XVII-XXV.

LINS, Álvaro \& FERREIRA, Aurélio Buarque de Holanda. "Nota biográfico-crítica sobre Valdomiro Silveira". In: __ \& _ . Roteiro literário de Portugal e do Brasil. 2. ed. rev. Rio de Janeiro, Civilização Brasileira, 1966. v. 2, p. 352.

LOPES NETO, J. Simões. Contos gauchescos e lendas do Sul. Ed. crítica com introdução, notas e glossário por Aurélio Buarque de Holanda Ferreira. Porto Alegre: Globo, 1961.

LOPEZ, Telê Porto A. "Introdução". In: ANDRADE, Mário de. Macunaíma: o herói sem nenhum caráter. Edição crítica de Telê Porto Ancona Lopez. Rio de Janeiro: Livros Técnicos e Científicos; São Paulo: Secretaria da Cultura, Ciência e Tecnologia, 1978.

LUKÁCS, Georg. A teoria do romance: um ensaio histórico-filosófico sobre as formas da grande épica. Trad. José Marcos Mariani de Macedo. São Paulo: Duas Cidades; Ed. 34, 2000.

Ensaios sobre literatura. Trad. Leandro Konder e outros. Rio de Janeiro: Civilização Brasileira, 1965.

. "La particularidad como categoría estética". In: Estética. Trad. cast. Manuel Sacristán. Barcelona, Grijalbo, 1966. v. 3, p. 233-275. 
. Marxismo e teoria da literatura. Trad. Carlos Nelson Coutinho. Rio de Janeiro: Civilização Brasileira, 1968.

MARROQUIM, Mário. A Língua do Nordeste: Alagoas e Pernambuco. $2^{\mathrm{a}}$ ed. São Paulo: Companhia Editora Nacional, 1945.

MARTINS, Nilce Sant'Anna. Introdução à estilística: a expressividade na língua portuguesa. São Paulo: T. A. Queiroz: Editora da Universidade de São Paulo, 1989.

MIGUEL-PEREIRA, Lúcia. "Valdomiro Silveira". In: __. Prosa de ficção (de 1870 a 1920). $3^{a}$ ed. Rio de Janeiro, José Olympio, 1973. p. 196-199. (Coleção documentos brasileiros, direção de Afonso Arinos de Melo Franco, v. n 63).

MONTEIRO LOBATO, J. B. Obra completa. $2^{\text {a }}$ ed. São Paulo: Brasiliense, 1950. $1^{\text {a }}$ série, Literatura geral; $2^{\mathrm{a}}$ série, Literatura infantil.

NUNES, Cassiano. "Valdomiro Silveira: um sistema de delicadeza". In: SILVEIRA, Valdomiro. Mixuangos. $2^{a}$ ed. Rio de Janeiro, Civilização Brasileira/ INL-MEC, 1975. p. XVII-XXXIX.

QUEIROZ, Maria Isaura Pereira de. Bairros rurais paulistas. São Paulo: Duas Cidades, 1973. . O campesinato brasileiro. 2. ed. Petrópolis: Vozes, 1976.

RAMOS, Graciliano. São Bernardo. Posfácio de João Luiz Lafetá. 34a ed. Rio de Janeiro: Record, 1979.

. Vidas secas. $5^{\text {a }}$ ed. Rio de Janeiro: José Olympio, 1955.

RAMOS, Hugo de Carvalho. Tropas e boiadas. 5. ed. Rio de Janeiro: José Olympio, 1965.

RAMOS, Péricles Eugênio da Silva. "Valdomiro Silveira e as origens do regionalismo sertanejo em nossa ficção". In: SILVEIRA, Valdomiro. Nas serras e nas furnas. Rio de Janeiro: Civilização Brasileira; Brasília, INL, 1975. p. XXXIII.

ROSA, João Guimarães. "Famigerado". In: Primeiras estórias. $14^{\mathrm{a}}$ ed. Rio de Janeiro: Nova Fronteira, 1985. . Grande sertão: veredas. 20ª ed. Rio de Janeiro: Nova Fronteira, 1986.

ROSENBAUM, Yudith. Metamorfoses do Mal: Uma Leitura de Clarice Lispector. São Paulo: Edusp/ Fapesp, 1999.

SILVEIRA, Maria Isabel. Isabel quis Valdomiro. Compilação de Miroel Silveira. São Paulo: Francisco Alves, 1962. v. 7. (Coleção Contrastes e Confrontos).

SILVEIRA, Valdomiro. "Cobra mandada". In:__. Leréias: histórias contadas por eles mesmos. 2. ed. Rio de Janeiro: Civilização Brasileira; Brasília, INL, 1975. p. 8-13. 
. Mixuangos. 2. ed. Rio de Janeiro: Civilização Brasileira; Brasília, INL, 1975. . Nas serras e nas furnas. Rio de Janeiro: Civilização Brasileira; Brasília, INL, 1975. . Os caboclos. $3^{\mathrm{a}}$ ed. Rio de Janeiro: Civilização Brasileira, 1962.

SOUZA, Bernardino José de. Dicionário da terra e da gente do Brasil. $5^{\mathrm{a}}$ ed. Belo Horizonte: Itatiaia, 2004.

SPINA, Segismundo. Introdução à edótica: crítica textual. São Paulo: Cultrix, Ed. da Universidade de São Paulo, 1977.

TAUNAY, Visconde de. Inocência. 28 ed. São Paulo: Ática, 1999. (Série Bom Livro).

TÁVORA, Franklin. O cabeleira. São Paulo: Ática, 1971.

TONICO \& TINOCO. “Chico Mineiro”, no cd Tonico \& Tinoco - vol. 2, gravação Warner, 1995.

VELOSO, Caetano. "Podres poderes”, no cd Velô, gravação Philips, 1989.

WISNIK, José Miguel. "O famigerado”. In: Scriptal Literatura. v. 5, n.10. Belo Horizonte: PUC/Minas, 2002. 


\section{VALDOMIRO SILVEIRA}

\section{MUCUFOS}

Edição anotada de uma coletânea inédita 


\section{ÍNDICE DE MUCUFOS}

P.

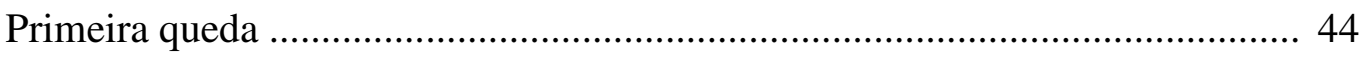

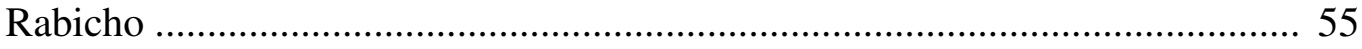

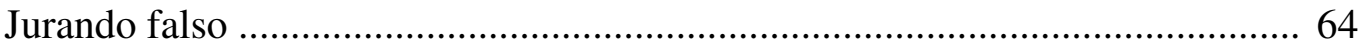

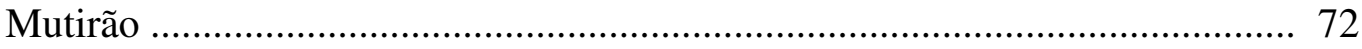

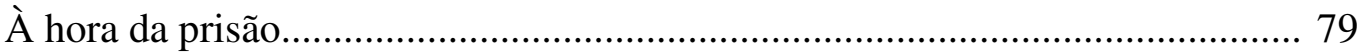

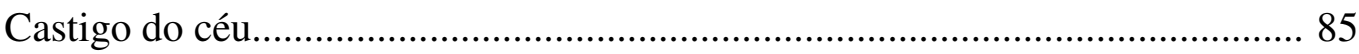

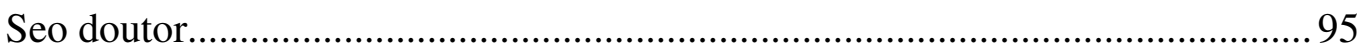

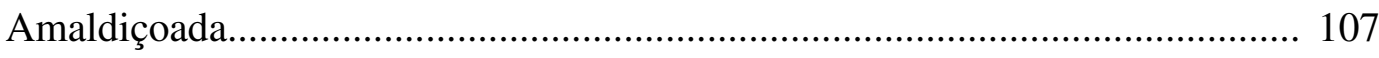

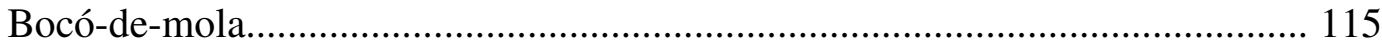

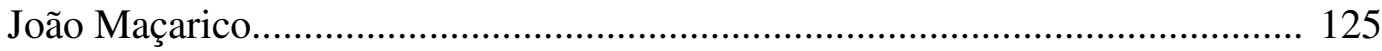

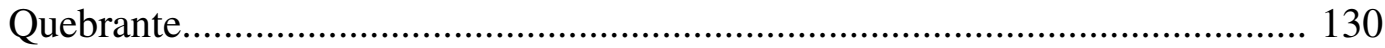

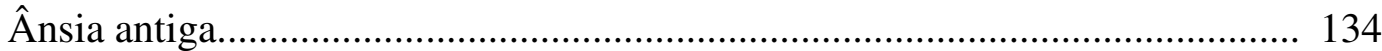

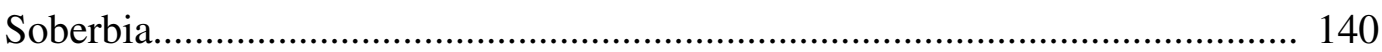

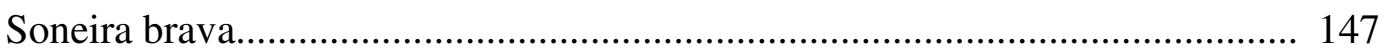

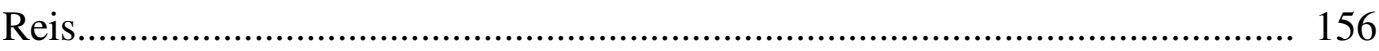

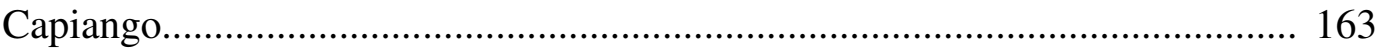

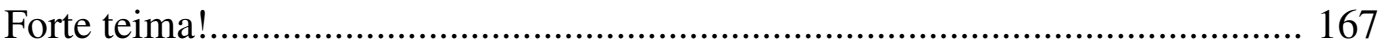

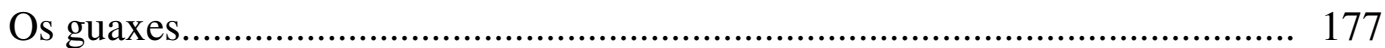

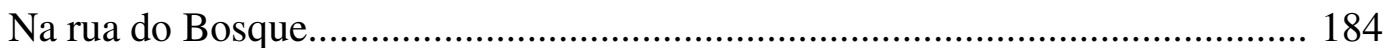

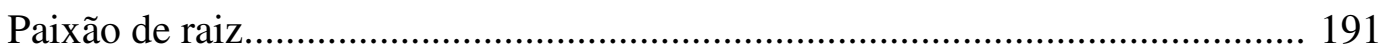

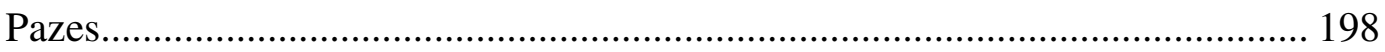

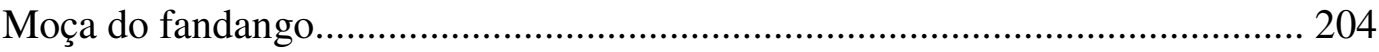

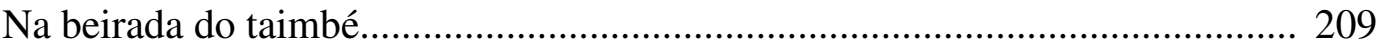

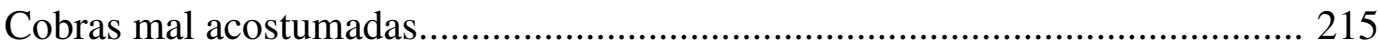

Vocabulário de Valdomiro Silveira no apógrafo de Mucufos............................ 222 


\section{$\underline{\text { Primeira queda }}^{41}$}

As sapucaias do mato virgem, quando um vento mais forte as agita, deixam cair ao relvedo da selva os frutos mais maduros. E tumultuam junto às raízes da árvore, alvoroçadas pelas cumbuquinhas que caem, as cutias gulosas e as pacas desconfiadas.

É nesse tempo que os caçadores preparam as cevas, de estaleiro ou de choça, armam os mundéus enganadores, e do escuro das árvores mais ramalhudas, ao cerrar da tarde, fazem traição ao macuco, arremedando-lhe os pios tristes e intervalados. A caçada é sempre farta: mas é doído que muita vez, ao troar da espingarda, que repercute pelas cavernas e grotas em acentos demorados e trêmulos, algum choro de sauá que se fez órfão atravesse as frondes, vingue a lomba do espigão, desça à várzea, morra espaçada e tremidamente.

Há caboclo ${ }^{42}$ que leva a dona do seu coração e essas festas de mortandade. E por isso quase sempre, ao calor sufocante do meio-dia, voam para o alto das montanhas bandos barulhentos de cantigas de amor, que o vento propaga e enternecidamente faz alongar pelas baixadas.

\footnotetext{
${ }^{41}$ Nota da edição: A versão dos textos dos contos, aqui apresentada com atualização ortográfica, corresponde à versão no apógrafo de Carmen Lydia de Souza Dias, o qual tomou como base o manuscrito de Mucufos, tal como ele se constituía entre 1976-1980, quando a pesquisadora teve acesso ao arquivo do escritor. Conforme a nota deixada por ela, os 24 contos da coletânea planejada por Valdomiro Silveira formavam um volume, possivelmente um datiloscrito. No momento da transcrição, em 1980, contaram com informações, colocadas "junto de cada texto", relativas a datas de redação e publicação. As notas que provinham da generosidade de D. Júnia Silveira Mendes Gonçalves, a filha mais velha do contista, encarregada de cuidar do espólio do pai, foram descartadas quando da transcrição. Bolsista da FAPESP, orientada pela Profa. Telê Ancona Lopez no Programa de Literatura Brasileira da Faculdade de Filosofia, Letras e Ciências Humanas da Universidade de São Paulo, Carmen Lydia defendeu sua tese de doutoramento, Paixão de raiz: o regionalismo de Valdomiro Silveira, em dezembro de 1980, tendo a mesma publicada pela editora Ática em 1984. Com o falecimento de D. Júnia, o arquivo perdeu a organização original, conforme se constata na documentação doada ao Instituto de Estudos Brasileiros em 2006 pela bisneta de Valdomiro, a jornalista Ana Maria Leal Góis de Mello. Deste modo, o volume que deu base ao apógrafo, não mais consta do arquivo e sobre ele não se tem mais possibilidades de explicação, pois Carmen Lydia também faleceu. No Arquivo Valdomiro Silveira, hoje no IEB, as pastas Mucufos e Originaes manuscriptos de Papae (preciosíssimos), conservam, respectivamente, 12 e 13 títulos do livro planejado. Assim sendo, as notas que recuperam datas de redação e de publicação serão aqui conhecidas como: Notas CLSD. Dos textos presentes no apógrafo, 12 estão na pasta dos manuscritos de Mucufos, porém em uma ordenação diferente: "Capiango", "Amaldiçoada", "Soberbia", "Forte teima!", "Paixão de raiz", "Quebrante", "Na rua do Bosque", "Somneira braba", "Bocó de mola", "Moça do fandango", "Reis" e "Pazes". Lá está ainda "A consulta do Lau", conto que não figurava no manuscrito que deu base ao apógrafo. Os manuscritos de VS estão descritos ao final desta edição de Mucufos, na "Análise documentária".

Nota CLSD: "Diário da Tarde. São Paulo, 10 fev., 1894".
} 
De vez em quando o rio que passa mais próximo trapeja mais forte, ao arrufar-se nos velhos troncos meio imergidos na água: estão no banho os caçadores. Não é raro então que tresmalhe do grupo um ou outro deles e se vá refrigerar dos calores dessa hora, ao longe, nos frescos braços da gentil cabocla que não duvidou perder-se nalguma picada cheia de labirintos. $O$ rio ronca às vezes, o beija-flor murmura com as asas ao redor do caeté desabrochado, a parasita de espinho debruça-se do seio da árvore onde fez morada, olha e admira-se: mas nada contam depois...

As histórias dessas fugas e escapadas - alegres, tristes, festivas, trágicas - vão-se fazendo complicadas e transformando em lendas, mais tarde, pelos arraiais. Uma das que os moços

\footnotetext{
${ }^{42}$ Nota da edição: De acordo com SOUZA, Bernardino José de. Dicionário da terra e da gente do Brasil. $5^{\mathrm{a}}$ ed. Belo Horizonte: Itatiaia, 2004, p. 59 e 60, o sentido da palavra caboclo, no contexto do conto, "segundo Teodoro Sampaio, vem do tupi caá-boc - tirado ou procedente do mato. É vocábulo muito correntio no Brasil, hoje, empregado em vários sentidos: ora para apelidar os aborígines, tanto mansos como bravios, donde as variantes caboclos mansos e caboclos bravos; ora, no sentido de descendente dos indígenas mestiçados com a raça branca; ora com a significação de sertanejo, caipira, homem da roça, do mato, de cor morena carregada, semelhante à dos primitivos habitantes do Brasil; ora, até no sentido de pessoa querida, como na frase - meu caboclo. Vale referir que nada mais arbitrário no linguajar brasileiro do que o uso dos nomes que designam os mestiços das três raças que entraram na formação do nosso povo. Nélson de Sena, nas suas Contribuições para a etnologia brasileira, escreve: 'Cabocos, como é a rude pronúncia vulgar, ou caboclos, segundo a prosódia erudita, representam o elemento indígena amansado e que das selvas viera coabitar com a gente civilizada; mas o legítimo caboco é também o mestiço de índio e, no sentido figurado, o tipo do homem valente e bem disposto; além de indicar o gentio que veio bravo do mato e, depois de manso, passa a viver no meio dos brancos'. Capistrano de Abreu, entretanto, escreveu no seu $O$ descobrimento do Brasil (Ed. da Soc. Capist. de Abreu, 1929 , pág. 123) que o caboclo era o filho de índio e africano, também chamado curiboca. Amadeu Amaral registrou cabocro - mestiço de branco e índio. Teschauer registra as formas caboco, cabocro, cabocolo, esta última referida na Informação Geral da Capitania de Pernambuco, publicada nos Anais da Biblioteca Nacional (Vol. 28 - pág. 483), nos seguintes termos: 'Cabocolos são os índios que moram na Costa e falam língua geral' em contraposição aos tapuias que são 'os naturais da terra, que vivem no sertão e não falam uma língua geral, senão cada nação a sua particular.' Ocorrem ainda as formas cabouco, cabôuculo, e as palavras caboclismo, caboclista, caboclada, cabocrada, caboclote, etc., etc".
} 
caipiras $^{43}$ sabem, nas fazendas do norte, é a da Clorinda, morena corada e matadeira, que tanto era mestra de temperar um jembê como uma viola, e estava sozinha para aporfiar com qualquer cantador dos mais afiados, num desafio.

Todo o mundo queria bem à Clorinda, porque ela falava a todo o mundo com o coração nas mãos e bondade na voz. E a voz era muito branda, como a de quem aprende, nos ermos, a não querer ser mais que a sapuva, cuja copa, sacudida pela aragem, nada mais faz que soluçar abafadamente, ou ir além da jurava, que, escondida nalguma touceira de jatiboca, diz por pios fundos e cavos a tristeza ou a alegria de que está possuída.

Ao primeiro vermelhar da madrugada, à hora inexpressiva em que os jacus estremunhados saltam de galho a galho, enchendo as clareiras do arvoredo com a sombra longa e apavorante dos seus vultos escuros e espectrais, a Clorinda fazia caminho para o

\footnotetext{
${ }^{43}$ Nota da edição: Segundo SOUZA, Bernardino José de. Op. cit., p. 68 e 69, caipira é o "nome com que se designa em S. Paulo e noutros Estados o habitante dos campos ou dos sertões. Valdomiro Silveira define-o muito bem: 'o homem ou mulher que não mora na povoação; que não tem instrução ou trato social: que não sabe vestir-se ou apresentar-se em público'. Equivale a aldeão, camponês, campônio, peludo em Portugal. No Brasil, há uma grande variedade de termos para designar o indivíduo que mora no interior, fora dos centros urbanos, mais ou menos equivalentes a caipira, uns generalizados por todo o país, outros restritos a certas regiões. É o caso mais abundante de polionímia que possui a nomenclatura geográfica peculiar ao Brasil. Tais são os seguintes, com a indicação das áreas geográficas onde são de uso mais correntio: de babaquara, muxuango (Campos de Goitacases), caburé (Mato Grosso e Goiás), chapadeiro, bruaqueiro, mandioqueiro, pioca (Minas Gerais), canguçu, caiçara (São Paulo), mandi (sul de S. Paulo e oeste de Minas), queijeiro (Minas e Goiás), tapiocano (Minas e Rio de Janeiro), capiau (Minas e Bahia), capuava (Bahia), casaca (Piauí), corumba (Sergipe e Pernambuco), curau (Sergipe), matuto (Minas, Rio, Bahia, Alagoas, Pernambuco até Rio Grande do Norte), piraquara (margens do Paraíba), roceiro (Rio de Janeiro, Mato Grosso, Pará, Bahia), restingueiro, sertanejo, tabaréu (Bahia, Sergipe, Distrito Federal, hoje, Estado da Guanabara), casacudo (sertão da Bahia), guasca, manojuca, jeca, mambira, (Rio Grande do Sul). Cornélio Pires, que tanto se dedicou ao estudo dos usos e costumes dos nossos caipiras, em seu livro Seleta caipira, define-os dizendo que 'são filhos das nossas brenhas, de nossos campos, de nossas montanhas e dos ubérrimos vales de nossos piscosos, caudalosos, encachoeirados e inumeráveis rios, acostelados de milhares de ribeirões e riachos'. Em seguida, o citado escritor divide-os em quatro classes: o caipira branco, descendente de estrangeiros brancos; o caipira caboclo, direto descendente dos bugres catequizados pelos primeiros povoadores do sertão; o caipira preto, descendente dos africanos já desaparecidos do Brasil; o caipira mulato, oriundo do cruzamento de africanos ou brasileiros pretos com portugueses, e brasileiros brancos, raramente com o caboclo, 'o mais vigoroso, altivo, o mais independente e o mais patriota dos brasileiros'. 'Aparece agora no nosso Estado (S. Paulo) um novo tipo de caipira mulato, robusto e talentoso, destacando-se, após ligeiros estudos, nos grandes centros, tratável e simpático: é o mestiço do italiano com a mulata ou do preto tão estimado por algumas italianas' (Cornélio Pires. Livro, citado. Pág. 27). Quanto à origem etimológica do vocábulo caipira há várias opiniões. Batista Caetano traduz caipira por pele tostada, de cai - queimada e pir - pele; Couto de Magalhães pensa que é uma ligeira alteração de caipira mondador do mato; outros o derivam de caapora, alteração de caai-pora, literalmente o que mora ou habita a mata; outros de curupira, gênio da mitologia americana nacional; Jaques Raimundo, em sua Tese, apresentada à Congregação do Colégio Pedro II, no Rio de Janeiro, diz que vem de caipira, particípio de cai - o envergonhado. Diante disto, vê-se bem que teve razão. Amadeu Amaral, quando escreveu: 'Como todas as palavras de aspecto indígena, real ou aparente, tem o vocábulo caipira fornecido largo pasto à imaginação dos etimologistas'. De caipira derivam os termos muito usuais: caipirada - ato de caipira ou grupo de caipiras, caipirice e caipirismo - ação de caipira, e mais caipiragem, encaipirar-se, encaipiração, encaipirado. Em Portugal, caipira era a alcunha depreciativa dada aos constitucionais durante as lutas civis de 1828-1843, usando-se também no sentido de avarento e sovina na província de Minho, segundo informa Cândido de Figueiredo".
} 
ribeirão que corria ao pé do serrote, longe da casa, lavava o rosto vagarosamente, e internavase nos trilhos e carreadouros. Ia visitar os mundéus e esparrelas, as arapucas e os laço-seforca; abafava, prudente, o estralejar dos gravetos: e era quase de sempre voltar feita um bando de passarinhos esvoaçantes e com uma fieira de nambus e urus mortos, quando não trazia também, a rasto, alguma paca chateada pela pressão do tronco de arindiuva que sobranceava a armadilha.

Vivia assim, despreocupada e livre, entre aves e entre flores. Não saberia explicar o motivo de se debicarem tão afagantemente os pavões, no esgalho dos ingazeiros, e de uivarem de maneira tão lamentosa os lobos, na meia-treva das noites de luar, quando foge o dia, a natureza se recolhe, e começa a apontar a lua, assustadoramente branca, na cumeada dos morros.

É verdade que a mãe, de quando em quando, lhe contava mal esclarecidos fatos: moças muito lindas e muito respeitadas, que se viram ao desamparo, de uma hora para outra, por conversarem tempo esquecido com fragueiros moços em lures apartados, o que aconteceu tão somente porque ouvissem demais a linguagem falsa e melada dos conquistadores. Mais a miúdo se contavam, na fazenda, as façanhas prodigiosas de Cabral, de Vasco da Gama e Colombo, que o patrão tinha escritos num livro grande -, e a Clorinda não caía em porque se havia de levar a mal a conversa de qualquer moça de preceito com qualquer daqueles homens que tinham, a todo o custo, conquistado a terra e o mar...

Indagava entre si o porque de ser pecaminosa tal conversa.

Não atinava com a razão dos avisos maternos. E horas e horas se perdia às vezes, em pensamentos desencontrados, carregadinhos de dúvidas, que se iam desfazendo numa vaga flutuação de devaneios, como, num recanto de céu, nuvens escuras, que prometem aguaceiros, vão pouco a pouco a trocar-se em rendas alvas.

Mal que os pais que lhe principiaram, de acautelados, a vigiar os passos, a Clorinda sentiu-se deveras constrangida. Surgia-lhe algum de repente, na doce quietez dos retiros. Por isso, não raro, assustava-se ouvindo o mourejar do vento nos ramos bem vestidos; estremecia toda, ao escutar a plangência da suindara, em caindo a noite, em qualquer tapera conhecida, porque naquela voz parecia, acreditado o dito do povo, adivinhar infelicidades que haviam de vir. Como uma obsessão, apoderara-se dela a idéia de que por toda a parte, em vários esconderijos, a estavam espreitando: e vivia, temerosa e seu tanto ou quanto amedrontada, na ânsia constante de quem pecou e precisa de fugir. 
Amava, contudo, os pais. Em tornando daquelas carreiras, procurava-os com solicitude, contando-lhes casos engraçados, trazendo novas de uma tararaca que dera um salto de duas ou três braças, de puro aterrorizada, entre um peloteiro e o galho mais caído de certo antonio-alves; de um nambuguaçu que repicava o pio roucamente: e até - coisa espantosa! De um gavião de penacho que se aventurara a arracncar de um mundéu, perto dela, um cateto novo, um leitãozinho, que esperneava ainda, nas vascas da agonia.

Um dia, como disse à mãe que topara um moço caçador chamado Eugênio, para as bandas da grota seca, em pós de um mateiro arrenegado, a mãe, com palavras meio veladas e fortemente persuasivas, aconselhou-lhe que não fosse mais a tais lugares e evitasse encontros perigosos assim. Admirou-se. Afigurava-se-lhe muito natural que os caçadores atravessem os mais cerrados matos e as mais apagadas veredas: quando se lhes some a caça cobiçada, é bem de ver que nada os detêm - valos, moitas de espinho, pedreiras, morros.

Se o Eugênio era caçador, seria de certo como os outros: e tinha ares de tamanha bondade, que não havia arrecear-se dele, senão por muita e dura injustiça. Não mudou de caminho: todos os dias ia visitar duas esperrelas que armara num paraíso, ao pé do ribeirão, morada efetiva dos sabiás-coleiros e unas de melhor estilo daquelas cercanias. Até, no mais íntimo de sua alma, chegava a querer observar se aquele moço teria olhares tão maus e palavras tão feias, quando acaso outra vez se defrontassem, nalgum trilho indeciso, sozinhos, à vista, apenas, de Deus.

Uma vez, afinal, como novamente o Eugênio lhe aparecesse, no abrir de uma porteira assombreada de canjaranas, ficou perplexa entre o cortejá-lo e o sumir-se mais que depressa nalgum densumbroso ramalhete de árvores. O destino deteve-a, que tem muita força $\mathrm{o}$ destino! - e o moço perguntou-lhe do rumo de um caminho perdido. Ora, vendo-a perturbada, perturbou-se também: mas a feiticeira Clorinda cobrou-se logo de espírito e ensinou-lhe todas as estradas de algumas duas léguas em redondo.

Não se movia o caçador, no entanto. A Clorinda, agora, recordava sensatas recomendações e conselhos maternos, que já andavam quase de todo em todo desleixados: não é bom dar trela nunca a jovens caçadores, quando ao perto se não ache algum conhecido: moço e moça não devem caminhar sem outra companhia, nos atalhos extravagantes e nas longas soledades.

No entanto, não se movia. E tendo sido convidada para ver matar uma cutia cevada nas sapucaias maduras, que a força do vento espalhava pelo chão acamado de folhas já 
murchas, foi coisa de admirar que tão depressa aceitasse o convite. E caminhavam juntos: as duas sombras, na areia branca entremeada de pedregulhos, aumentavam de tamanho, agitavam-se, faziam-se monstruosamente grandes, ao lado uma da outra. Penetraram a mata, num ponto em que havia montões de ramos quebrados, ao bulir ondulante das folhas tocadas, e fazendo um rumor precatado, quase nem um.

Já muito longe, à beira de um solapão hiante e profundo, que da aguada subia para a plena mata, pararam. Dormia a mata. Quedaram não poucas horas à espera da cutia. A cutia não vinha. Os vegetais conservavam-se imóveis. A demora não era já pequena. Nada quebrava o silêncio e a soneira das árvores, que se diria estarem tomadas do êxtase de um rico sonho. Os mesmos passarinhos mais irrequietos - patativa do sertão, bico-pimenta, alcaide, picharro - não davam cópia de si. E o Eugênio e a Clorinda, ansiosos, esperavam...

Mas, a súbitas, pesado rumor se fez ouvir ao longe. O Eugênio prestou atenção, concheou a mão direita atrás da orelha, empalideceu: e observou à companheira que uma grossa nuvem de caçunungas vinha chegando. Caçunungas! Caçunungas! - só de pensar naquele enxame de marimbondos bravios, a Clorinda, tapijara de toda a paragem, disposta e valente, começou, entretanto, a tremer. E o enxame aproximava-se: parecia o trovejar das águas de um alto açude que rompeu represas possantes e agora, no meio da calma embasbacada dos arredores, descia vitoriosamente até o ribeirão de onde o tiraram.

Houve uma tal igualdade de pensamentos, no mesmo elo de medo, que se deitaram lado a lado, unindo-se bem ao chão, precavidos contra a nuvem que passaria a uns dois metros acima, negra e agitada e quase a urrar. O que, porém, não entrava no capítulo, foi o pegarem a beijar-se os dois, quando se avizinhavam os caçunungas, enquanto passavam, depois que se afastaram. Não era da caçada! E a Clorinda, bem no fundo da sua alma singela, entrara a pensar que a mãe a enganara, porque o Eugênio, um caçador como os demais, não tinha, entretanto, ditos ou feitos que espantassem, que a deixassem na tristeza, na vergonha ou na desconsolação de uma descortesia recebida.

Os caçunungas, em bando compacto, desapareceram na escureza das brenhas. Ainda rouquejou, muito tempo, o rumor que faziam, perfeita semelhança do temporal que se alonga. Mas o caçador e a caçadora, numa constante igualdade de pensamentos, detiveram-se à beira do solapão, distraídos, esquecidos, comovidos. Só deram tento da vida, só pensaram em tornar para seus pagos quando se viu o primeiro piscar das estrelas no céu. 
Voltaram. Na estrada alva os dois vultos cresciam fantasticamente, agora sombrios e mais anchos. Os purrutuns apavorados levantavam cansados vôos adiante deles. E toda a mata, em seguida, readormecia muito serenamente.

Quando o Eugênio, na sofralda do espigão, teve de se despedir da moça, a moça chorava: prantos de amor que nasceu na incerteza de uma hora turva! E chorou no dia seguinte: mágoa quase doce de quem principia a aprender o sofrimento no que ele tem mais meigo e mavioso. E chorou nos outros dias: ânsia de quem, não sendo passarinho, ama com ternura e afã de pomba-piranga, e desejo de rasgar um violento vôo para onde crê se esconde o companheiro. Depois, saudades.

Mas o tempo tudo apaga. Ela veio a consolar-se: viram-na de novo as capituvas amigas, banharam-lhe outra vez o corpo as águas esquecidiças do ribeirão, que passam e não remontam; apareceu nos catiras, onde, foi coisa não costumada aquilo - por seu amor apareceram crencas e contendas.

Hoje, segundo a unânime afirmação dos moços caipiras, nas fazendas do norte, a Clorinda cai tal e qual as sapucaias do mato virgem... 


\section{$\underline{\text { Análise do conto }}$}

"Primeira queda" é o primeiro texto da obra Mucufos, inédita em livro, contando vinte e quatro contos escritos entre 1894 e 1938. Foi publicado pela primeira vez no Diário da Tarde, de São Paulo, em 10 de fevereiro de 1894.

Não apresenta diálogos entre as personagens. O conto, totalmente narrado em terceira pessoa, é longo e explora especificamente o registro do caso.

O caso ou "causo" (no falar caipira), em "Primeira queda", relata a primeira paixão de uma moça recatada e bem educada dentro da moral católica, Clorinda, por um jovem caçador, Eugênio. A mãe de Clorinda, guardiã dos bons costumes e, porque não dizer, do tabu da virgindade de sua filha, vivia alertando-a para o "perigo" de certas escapadas mato adentro. Mas Clorinda, amante das coisas da natureza, continuava. Um belo dia, numa dessas "fugas", na expressão do narrador, conheceu Eugênio e, contando à mãe o acontecido, esta a aconselhou a não mais ir a lugares onde pudesse estar diante da "tentação de pecar contra a moral católica". Porém, Clorinda reencontrou Eugênio que a convidou para uma caçada de cotia, durante a qual, a passagem de um bando de caçunungas propicia o encontro amoroso, sucedido imediatmente pela separação. O título do conto, "Primeira queda", já anuncia a condenação presente na narrativa, a qual coincide, com uma espécie de condenação que aparece numa certa linha de contos a qual, nos séculos xviii e xix, desenvolveu casos de cunho moral. Sobre eles esses casos, diz André Jolles:

\footnotetext{
“Os Casos que resultavam das controvérsias morais conservaram-se num círculo exíguo, tanto mais que não houve adversário em condições de usar e abusar deles. Creio, entretanto, que exerceram grande influência sobre a literatura em geral. Talvez fosse mais apropriado dizer que a mentalidade que se manifestou no seio da Igreja católica e no domínio restrito da teologia moral influi igualmente na literatura, em seu todo. Com efeito, a literatura dos séculos xviii e xix pesa e mede os motivos de uma ação de acordo com normas internas e externas, às quais deu geralmente o nome de psicologia; esse critério fluido no julgamento dos personagens de uma obra artística como tal parece-me estar muito próximo do critério que vemos aplicado na casuística. Mas tais considerações tampouco têm lugar numa obra dedicada à Morfologia das Formas Simples"44.
}

\footnotetext{
${ }^{44}$ JOLLES, André. “O caso”. In:___. Formas simples. Trad. Álvaro Cabral. São Paulo: Cultrix, 1976. p. 166.
} 
Podemos observar no conto alguns traços característicos do romantismo, tais como expressões carregadas de sentimentalismo. São elas: “com o coração nas mãos”, "bondade na voz" e "a voz era muito branda", como se observa neste trecho:

\footnotetext{
“Todo o mundo queria bem à Clorinda, porque ela falava a todo o mundo com o coração nas mãos e bondade na voz. E a voz era muito branda, como a de quem aprende, nos ermos, a não querer ser mais que a sapuva, cuja copa, sacudida pela aragem, nada mais faz que soluçar abafadamente, ou ir além da juruva, que, escondida nalguma touceira de jatiboca, diz por pios fundos e cavos a tristeza ou a alegria de que está possuída".
}

Outro traço característico do romantismo é a comparação de qualidades humanas com elementos da natureza (ao estilo de José de Alencar, por exemplo, em obras como $O$ Guarani e Iracema), tal como aproximar a voz branda de Clorinda ao soluço abafado na copa de uma sapuva ao ser "sacudida pela aragem" e com os "pios cavos" de uma juruva. Os escritores românticos brasileiros, numa atitude bastante nacionalista, valorizavam muito a fauna e a flora de seu país.

Antonio Candido, dissertando a respeito do regionalismo, afirma que o romântico (representado por escritores como José de Alencar, Franklin Távora e o Visconde de Taunay) apresenta grande consciência e lucidez ao distinguir "a qualidade do homem e da paisagem", enquanto que a "literatura sertaneja" pós-romântica, representada por Afonso Arinos, Simões Lopes Neto, Valdomiro Silveira, Coelho Neto e Monteiro Lobato é "alienada e perniciosa". Em vista disto, o regionalismo dos românticos Alencar, Távora e Taunay é mais "verdadeiro e fecundo" do que a "literatura sertaneja" pós-romântica ${ }^{45}$.

A presença do alto teor sentimental neste conto, assim como na maioria dos contos em todo o conjunto da obra de Valdomiro Silveira, também nos remete ao juízo crítico de Antonio Candido a respeito do autor de Mixuangos. Este crítico diverge de Alfredo Bosi, quem, segundo vislumbra, nos "regionalistas de programa" do final do século xix uma promessa de renovação estética que, de fato, viria. Situa Valdomiro Silveira no seio do confronto entre a literatura regionalista que vigora a partir de 1890 e a literatura acadêmica de então. Ao julgá-lo contaminado pelos vícios daquela época, tais como o excesso de sentimentalismo, de nacionalismo, de descrição de certos elementos da natureza e a recorrente procura do "pitoresco", mostra-o como suspeito de reificar seu objeto de projeção literária, o

45 CANDIDO, Antonio. "Novas experiências". In: Formação da literatura brasileira. $4^{\mathrm{a}}$ ed. São Paulo: Martins, 1975. v. 2, p. 211. 
caipira. Deste modo, prossegue o crítico, o escritor, assim como quase todos os regionalistas de seu tempo, se torna responsável pela "criação de um sentimento subalterno e fácil de condescendência em relação ao próprio país", na medida em que, na obra que produzem, o caboclo é encarado do ponto de vista "pitoresco, sentimental e jocoso", o que produz alterações de idéias, tanto no aspecto social como estético ${ }^{46}$. Para Carmen Lydia de Souza Dias, é importante "relembrar que estes juízos de Antonio Candido não afastam a idéia, várias vezes emitida por ele próprio, da necessidade da etapa regionalista, muito embora discrimine particularmente alguns dos seus produtos "sertanejos", mesmo reconhecendo em alguns deles a habilidade no manejo da matéria regional" (DIAS, Carmen Lydia de Souza. Paixão de raiz: Valdomiro Silveira e o regionalismo. São Paulo: Ática, 1984, p. 26).

O autor dá ao seu narrador uma certa erudição pomposa, principalmente no plano sintático e no morfológico. Esta erudição vem da formação clássica de Valdomiro que leu autores do porte de Machado de Assis, Luís de Camões, Camilo Castelo Branco, Vieira, Eça de Queirós e Bernardim Ribeiro, copiando muitas frases-modelo que, em geral, foram construídas com particular engenho sintático, segundo Carmen Lydia de Souza Dias em Paixão de raiz: Valdomiro Silveira e o regionalismo, São Paulo: Ática, 1984, p. 202 (nota $\mathrm{n}^{\circ} 18$ ).

Podemos observar um pouco da erudição do narrador-autor logo no primeiro parágrafo de "Primeira queda", no qual ele praticamente não usa o falar caipira. Prefere construções do português culto, que mostram uma boa dose de distanciamento entre um narrador culto e o objeto de sua projeção literária, o caipira:

\footnotetext{
"As sapucaias do mato virgem, quando um vento mais forte as agita, deixam cair ao relvedo da selva os frutos mais maduros. E tumultuam junto às raízes da árvore, alvoroçadas pelas cumbuquinhas que caem, as cutias gulosas e as pacas desconfiadas".
}

O tom erudito do conto coexiste com uma profusão de perífrases, apostos e regionalismos, os quais podem ser considerados como interferências no enfoque humano, segundo Carmen Lydia de Souza Dias (op. cit., p. 26). Isso desvia o leitor da atmosfera requerida para o desenrolar da ação:

\footnotetext{
${ }^{46}$ CANDIDO, Antonio. "Literatura e cultura de 1900 a 1945". In: Literatura e sociedade. São Paulo: Nacional, 1965. p. 136.
} 
“Amava, contudo, os pais. Em tornando daquelas carreiras, procurava-os com solicitude, contando-lhes casos engraçados, trazendo novas de uma tararaca que dera um salto de duas ou três braças, de puro aterrorizada, entre um peloteiro e o galho mais caído de certo Antonio-alves; de um nambu-guaçu que repicava o pio roucamente; e até - coisa espantosa! De um gavião de penacho que se aventurara a arrancar um mundéu, perto dela, um cateto novo, um leitãozinho, que esperneava ainda, nas vascas da agonia”.

O tema do conto é a caça e o motivo principal a prostituição; os secundários são os ditos populares, a alimentação e a solidão. $\mathrm{O}$ conto procura reconstituir o trajeto que percorrem certos motivos correntes nos casos contados e repetidos pelos caipiras, até se transformarem em motivos lendários (V. Carmen Lydia de Souza Dias, op. cit., p. 16). Essa reconstituição se constitui em um genuíno processo de formação de uma lenda caipira que, no caso do conto, é o aparecimento de uma mulher, Clorinda, nas "fazendas do norte", caindo "tal e qual as sapucaias do mato virgem", depois de ter morrido pensando demais em seu amor, Eugênio, a quem acompanhara em uma caçada. 


\section{$\underline{\text { Rabicho }}^{47}$}

As guaricangas tremiam, sussurrando soluços, porque um vento bravo passara pelo brejo e tivera o atrevimento de bulir com elas: vendo as palmeirinhas tremer assim e os sacis bater as asas cheias de riscas, fazendo tal e qual como quem está presa de susto ou dor, a gente - se fosse crendeira - diria que a tristeza andava passeando aquela tarde pelo país do rio verdinho.

$\mathrm{Na}$ verdade, isso não podia continuar. A madrugada rasgara-se acompanhada de ventania: o sol apareceu, sem que a ventania abrandasse; e agora, com as primeiras fusquinhas do crepúsculo no ocidente, a ventania ainda se tornara mais irada.

Vem a hora de passar o bando dos patos, a hora em que os piris e as taboas palpitam no cimo d'água, saudando-os. A terra inteira pareceu recolher-se para receber no âmago o derradeiro espasmo do sol: assim que ele imergiu no fundo das montanhas, ela agitou-se por instantes numa convulsão demorada, e cobriram-se de vivo sangue as copas dos angicos, até aí virginalmente brancas.

Mais tempo, menos tempo, saía de um rancho sufocado entre dois montes, a um lado do rio verdinho, o Renato da Mantiqueira, montado num cavalo mouro. Arranjara o animal a capricho, levando-o primeiro, raspando-lhe o pêlo depois; selara-o com um socado de sorocaba, dos bons, adicionando-lhe peitoral e caçambas de prata que tiniam. Teso e cheio de não-me-toques, ganhou a estrada que dizia para a grama; assobiou a música da araúna, ergueu ao ar o chicote de bonito lavor, desceu-o às ancas do mouro, e seguiu com vontade.

Seu coração batia forte, acompanhando quase o viajeiro da cavalgadura: chegou a pensar umas coisas esquisitas, que eram comparações dos estrupidos das patas com o barulho do coração, perguntando a si mesmo o que seria que andava mais ligeiro - o coração ou cavalo?

Encontrou gente como formiga. Aborreceu-se um nada. Queria-se não visto e só, abrindo e fechando porteiras, namorando a estrela do pastor que não tardaria a entrar no circo imenso do firmamento; queria-se invisível entre os andaaçus marginais da estrada real: amaldiçoou, no íntimo, aquelas pessoas que o observavam com tal insistência, que se diria

\footnotetext{
${ }^{47}$ Nota CLSD: "Diário Popular. São Paulo, 13 set., 1894. (Escrito em Casa Branca)".
} 
estarem resolvendo interrogá-lo a cada sombra mais densa de gurrupiazeiro, onde luzia em triunfo a prataria dos bocais do mouro.

Deu-lhe na gana gritar que ia ver a Anica, a dona dos olhos mais perigosos de toda a redondeza, a rapariga que ao andar tanto e tão bem rebolava o corpo, que o corpo dela fazia pensar-se numa colina de geléia deliciosíssima. Ia, pois vê-la: que importava isso aos bocós, agora? Teve desejos de livrar o peito da jeriza que o oprimia. Quis mandar os importunos cavaleiros e viandantes aos quintos dos infernos. Quis dizer muito; mas continuou sem dizer nada, mas continuou a assobiar a música da araúna.

O engraçado foi que no alto de um morrinho, por sinal que um morrinho todo florescido de maravilhas, um nambu mineiro estava piando com delícias. Havia já pedaço, principiara uma série de pios, e não conseguira chegar ao fim, pois um outro lhe volvera pronta resposta, escondido numa touceira de maçambará. O Renato passou e, como recomeçasse a predileta canção, o sonso do nambu tomou vôo contra ele, cuidando-o por certo algum rival que requestava a mais que desejada nambu.

O Renato levantou o chicote, varejou-o, empuxando-o contra o chão. E reparando nele, que se estorcia nas vascas da morte, murmurou:

- Se até os passarinhos já têm ciúmes de mim, que dirá certa gente que se morre de amores pela Anica!

Aquela idéia atravessou-lhe o espírito, como um morcego o silêncio de uma igreja. Sobre ela acumularam-se outras, não menos ruins. Sobre estas, outras piores. De modo que o rapaz, de alegre que estava, se pôs a banzar. Lembrou-lhe um fato, o de lhe haverem contado que o pai da moça jurara matá-lo, se o soubesse rondando junto às janelas do terreiro.

Isso já era demais. Virava de zanga em ameaço. Enfurecesse-se o velho, tinha lá suas razões. Mas ameaços, não os fizesse, que um peitudo da Mantiqueira não conta com desgraça de jeito nenhum!

Quem pagou tudo, foi o mouro. Vergastadas intercadentes lambiam-lhe com raiva as paletas. Murros - até murros! - adormeceram-lhe as fibras de sob as crinas. Pés nervosos, descalços, correram-lhe as virilhas, por feição que o deixaram mais do que triste. Um animal de estimação, como ele, apanhado à semelhança de burro chucro, já se viu só?

A noite, que era de lua, veio com todo o vagar. Suindaras gemiam perdidas numa lonjura incalculável e um beija-flor sem juízo trinava, apesar de vinda a noite, no ramo cimeiro de uma arvoreta. O Renato sentiu-se tomado de súbita melancolia; puxou as rédeas, 
parou, dirigiu ao pássaro a mágoa de que percebia inundados os próprios olhos, e ouviu-o cantar. A estrela do pastor já fulgia no céu e ele pensou entre si:

- Pode que o louquinho do beija-flor se esteja finando de paixão pela estrela!

E depois acrescentou:

- Mas é mesmo um louquinho o tal, que não pode ter certeza de ser correspondido. Eu, que gosto da Anica, sei pelo menos que ela gosta de mim. Gosta muito, mas mesmo muito!

Em seguida, abstraiu-se, com uma penetração estranha de vista para o mistério claro do luar, e murmurou:

- Homem, quem sabe?

Estalaram chicotadas. O mouro disparou num galopão. Por quê? Porque o Renato precisava conhecer o amor que a Anica possuía no coração de moça nova. Apresentara-se uma dúvida: pressa se dava ele em desvendá-la.

Para logo romperam do lago de luar que transbordava pela estrada, ramalhetes de vegetação densa e altaneira. Eram três jatobás que assombreavam a casa da linda Anica, e, achando-se perto deles, o rapaz achou-se perto do peito dela...

Ai! Que julgava já vê-la, num vulto visto à porta da casa! Mas não, não era! Talvez alguma pomba esquecida do ninho, enrufando as penas, pousou ali e contemplava a serenidade do espaço: quem sabe se uma travessa marrequinha, das alvas, estava perlongando aquelas regiões, antes de tornar à quentura do ninho? Não, não era a moça!

Não era, mas então o que seria?

Foi-se aproximando. $\mathrm{O}$ vulto deu de crescer, de crescer. Cresceu de tal modo, que, afinal, o Renato reconheceu nele a Anica.

As madressilvas de uma cerca próxima rescendiam; as laranjeiras vestiam-se de noivas e, noivas perfumosas, enchiam o ar de piras emanações: de vez em vez uma viração mais apressada mergulhava nas ramarias, e formava-se-lhes em torno uma atmosfera de inocência e de sonho.

O Renato achou-se envolvido na pureza dessa atmosfera e acreditou-se levado aos sete céus da felicidade.

A prova é que falou, numa voz que se diria de êxtase:

- Anica, está deveras distraída!

Ela respondeu numa voz que era mais branda que um arrulho:

- Tenho motivos para distração.

- Para alegria? 
- Antes fosse. Para distração que termina em sofrimento.

- Pois, Anica, uma coisa lhe juro: você empregava com acerto os seus pensamentos, se eles ficassem presos numa idéia.

- Qual idéia, Renato?

- A da nossa dita.

- Aí está um impossível!

- Impossível, se você quer que seja impossível.

- Não, eu não quero.

- Então, você tem estima por mim?

- Não sei.

Às vezes o não sei é dito de tal forma que já é uma afirmativa. O Renato alegrou-se, e teve os olhos úmidos de satisfação. E daí sua voz banhou-se de satisfação também, como os olhos, saindo-lhe trêmula:

- Já vê que nós havemos de ser ditosos.

- Não, atalhou Anica: não, porque papai não admite nem que se toque nesse assunto.

- Que me importa?

- Mas você bem sabe que eu sou de menor idade.

Nesse momento, reboou na calma da noite uma apóstrofe terrível:

- Desgraçado! Saia de lá que, senão, corre perigo!

- É a voz de papai, aventurou Anica: fuja! Fuja!

O Renato, porém, quedou-se-lhe à beira. Tomou-lhe uma das mãos, e bradou com toda a energia:

- Quero muito bem a ela. Ela me quer muito bem. Deixe que nós casemos, é o que lhe pedimos.

- Maldito! - a voz continuou: nunca eu lhe entregaria minha filha!

- Nunca?

- Nunca.

O Renato perguntou à Anica:

- O seu amor é grande?

-É.

- Você faz loucuras que eu fizer?

- Faço. 
- Suba à garupa do mouro.

Ela montou. Cingiu-lhe o corpo com os seus braços cor de leite, notou que ele os premia com afeição e creu-se venturosa.

O cavalo partiu num galopão desfeito. Viu-se uma fímbria de nuvem ondulando-lhe sobre a cauda, uma nuvem de cassa ou de cambraia, e um longo chapéu de feltro, de abas largas, a sumir na indecisão do luar. Depois, nada mais do que... Poeira, poeira e mais poeira... 


\section{$\underline{\text { Análise do conto }}$}

No segundo conto, de Mucufos, "Rabicho", escrito em Casa Branca e publicado no Diário Popular, São Paulo, em 13 de setembro de 1894, segundo indicação no apógrafo, encontramos o diálogo das personagens em coloquial culto:

"O Renato levantou o chicote, varejou-o, empuxando-o contra o chão. E reparando nele, que se estorcia nas vascas da morte, murmurou:

- Se até os passarinhos já têm ciúmes de mim, que dirá certa gente que se morre de amores pela Anica!”

No trecho acima podemos observar o uso de palavras eruditas, tais como "varejou-o", "estorcia" e "vascas". Mas o teor culto é refreado logo em seguida, na fala da personagem Renato que faz uso de expressões mais coloquiais, como "já têm ciúmes de mim" e "morre de amores".

Quase não encontramos arcaísmos no conto, a não ser "jeriza” (arcaísmo de forma), vocábulo oriundo de ojeriza, "antipatia a pessoa ou coisa", de acordo com o Novo dicionário Aurélio da Língua Portuguesa ( $2^{\mathrm{a}}$ ed. rev. e ampl. Rio de Janeiro: Nova Fronteira, 1986. p. 1218).

Em termos sintático-morfológicos, pouca coisa no conto prenunciaria o mesmo autor regionalista revelado em outros contos de Mucufos, como "Amaldiçoada", texto onde há uma aproximação maior, em termos lingüísticos, entre o narrador (que conta a estória parte em coloquial culto, parte em falar caipira) e as personagens (que dialogam em falar caipira).

O único traço comum entre "Rabicho" e "Amaldiçoada" está no plano do léxico, com a menção a animais, plantas e utensílios diversos, de teor regional. Vale lembrar que Valdomiro Silveira estudou Botânica e Ornitologia para melhor construir a coerência de sua ficção, quando se tratava de elementos do espaço.

Em relação a "Rabicho", podemos afirmar que foi o primeiro conto verdadeiramente regionalista escrito por Valdomiro, publicado, pela primeira vez, no Diário de S. Paulo, em 1894, conforme anotação no apógrafo. Há uma polêmica em relação à precedência do autor, em relação a Afonso Arinos, na prática da ficção regional. Para Carmen Lydia de Souza Dias, a discussão em torno de quem teria sido o primeiro a publicar uma obra regionalista "não é elemento a ser intrinsicamente valorizado. Constitui, porém, entre outros, mais um traço de coerência na expressão de toda uma postura empenhada: a mesma que transparece na ficção, na crônica e na oratória, e se configura, em 
síntese, como o compromisso frente à realidade brasileira, não obstante limitações no campo da consciência histórica"48.

Para Carmen Lydia, o que realmente deve ser levado em consideração é a intenção dos autores de retratar com bastante veracidade e envolvimento emocional todo um contexto sócio-cultural que cerca o modo de ser e de viver do caipira. A "postura empenhada" referida por ela nos remete às idéias de Georg Lukács ${ }^{49}$ e Antonio Candido ${ }^{50}$ a respeito da função social que uma obra de arte deve ter numa sociedade dividida em classes. Função esta que, para Lukács e Candido, deve ser humanizadora e, ao mesmo tempo, provocar no leitor uma reflexão crítica (visando uma conscientização social) em relação à sociedade em que ele vive. Neste sentido, considerando Valdomiro Silveira, pensa-se com a autora de Paixão de raiz: Valdomiro Silveira e o regionalismo, que a obra de arte deve se empenhar em provocar, em seu trabalho estético, um "nacionalismo de reflexão, passível de se revelar através dos contos", $"$.

Em "Rabicho", à semelhança de "Primeira queda", encontramos alguns traços românticos, tais como o sentimentalismo e a moral ligada a valores religiosos (no caso, os do catolicismo, religião predominante no Brasil daquela época).

O sentimentalismo pode ser observado na seguinte passagem de "Rabicho":

“As madressilvas de uma cerca próxima rescendiam; as laranjeiras vestiam-se de noivas e, noivas perfumosas, enchiam o ar de puras emanações: de vez em vez uma viração mais apressada mergulhava nas ramarias, e formava-se-lhes em torno uma atmosfera de inocência e de sonho.

O Renato achou-se envolvido na pureza dessa atmosfera e acreditou-se levado aos sete céus da felicidade.

A prova é que falou, numa voz que se diria de êxtase:

- Anica, está deveras distraída!”

As expressões "atmosfera de inocência", "de sonho" e "levado aos sete céus da felicidade" traduzem muito bem o clima romântico e sentimental do conto. Também é interessante notar a comunhão proporcionada pela natureza (mais um traço romântico) com o sentimentalismo do

\footnotetext{
${ }^{48}$ DIAS, Carmen Lydia de Souza. Op. cit., p. 53.

49 LUKÁCS, Georg. Ensaios sobre literatura. Trad. Leandro Konder e outros. Rio de Janeiro: Civilização Brasileira, 1965.

${ }^{50}$ CANDIDO, Antonio. "A literatura e a formação do homem”. In: Textos de intervenção. São Paulo: Duas Cidades; Ed. 34, 2002. p. 77-92.

${ }^{51}$ DIAS, Carmen Lydia de Souza. Op. cit., p. 52.
} 
encontro amoroso. As madressilvas e as laranjeiras contribuíam para formar a "atmosfera de inocência e de sonho".

A atmosfera excessivamente sentimental que perpassa todo o conto casa-se muito bem com o título dele. A palavra "Rabicho" é um brasileirismo que significa "amor, paixão" 52 . E é o amor o tema do conto.

Em relação à moral, o diálogo entre Renato e Anica nos mostra, em boa medida, a intransigência na oposição do pai de Anica àquele relacionamento amoroso:

“- Já vê que nós havemos de ser ditosos.

- Não, atalhou Anica: não, porque Papai não admite nem que se toque nesse assunto:

- Que me importa?

- Mas você bem sabe que eu sou de menor idade".

Há também, no âmbito dos impedimentos tão caros ao romantismo, a questão de Anica ser "de menor idade". Esse obstáculo se vê superado num impulso, quando o par recorre à fuga. A moral tratada no conto, no qual aparece como um motivo secundário (empregado na acepção de Wolfgang Kayser) ${ }^{53}$, vai ao encontro do que Jolles assevera ser concernente à casuística, que surgiu no seio da Igreja Católica a partir do final do século xvi. Essa casuística penetrou na forma do caso que, ao tratar do tema do amor desde a época do amor cortesão, imprimiu no caso um determinado tipo de moral. Sobre isso, afirma Jolles:

"Já não se trata da moral com normas absolutas, como nos Mandamentos, nem de uma moral que consubstanciaria o livre impulso moral da fé; trata-se, antes, de uma moral que pesa as diferentes normas, de uma moral na escala móvel da avaliação, de uma moral equilibrista - termo que utilizamos em sentido perfeitamete sério. Parece-me ser clara a oposição entre essa moral e uma escolástica que procurava, tanto quanto possível, apreender as virtudes e os vícios como objetos; e também me parece evidente que tal avaliação tinha finalidades essencialmente humanas, não se limitava a proteger o penitente das concepções pessoais e dos humores do seu confessor; protegia-o também do desespero em face do pecado absoluto, que é o pecado mortal, e facilitava-lhe, portanto, o caminho do céu" ${ }^{\text {" }}$.

O texto, também, apresenta certo tom jocoso, contrastando com o clima tenso provocado pelo aparecimento do pai da moça, quando Renato tratava do futuro de felicidade:

\footnotetext{
${ }^{52}$ FERREIRA, Aurélio Buarque de Holanda. Op. cit., p. 1441.

${ }^{53}$ KAYSER, Wolfgang. Análise e interpretação da obra literária. $5^{\mathrm{a}}$ ed. portuguesa revista pela $12^{\mathrm{a}}$ alemã por Paulo Quintela. Coimbra: Arménio Amado, 1970. v. 1, p. 80.

${ }^{54}$ JOLLES, André. Op. cit., p. 165.
} 
"Nesse momento, reboou na calma da noite uma apóstrofe terrível:

- Desgraçado! Saia de lá que, senão, corre perigo!

- É a voz de Papai, aventurou Anica: fuja! Fuja!”

Chega a ser engraçada a cena transcrita acima, ainda mais observando-a com o olhar do princípio do século xxi, onde os valores morais se encontram muito mais flexíveis e permissivos do que no final do século xix. Pode-se afirmar que é tragicômica, na medida em que apresenta a reação violenta de um pai que procurava salvaguardar os valores morais de sua família ${ }^{55}$. Um deles, pode-se afirmar, é o tabu da virgindade de Anica que, nos dias de hoje e mesmo a moça sendo "de menor idade", soa como algo anacrônico. Daí a cena adquirir o poder de nos provocar o riso, pelo exagero da reação violenta do pai, que chega a ser um tanto quanto caricata.

A propósito da concepçãoda natureza, Flávia Paula Carvalho afirma que o romantismo “inaugurou a visão da natureza enquanto paisagem digna de ser admirada, e a função de quem a descreve é procurar transmitir aos outros sua admiração ou até mesmo seu êxtase" A natureza na literatura brasileira: regionalismo pré-modernista. São Paulo: Hucitec: Terceira Margem, 2005. p. 51.

\footnotetext{
${ }^{55}$ A respeito da violência no âmbito familiar, ver FRANCO, Maria Sylvia de Carvalho. Homens livres na ordem escravocrata. $3^{\text {a }}$ ed. São Paulo: Kairós, 1983. p. 40-47.
} 


\section{$\underline{\text { Jurando falso }}^{56}$}

Dizer o que era a Nanica, nos tempos em que o José das Perovas pegou de amores com ela, é coisa quase impossível: só mesmo se se lhe visse o retrato é que se convenceria a gente da formosura perigosa que a diaba tinha. Chamavam-lhe Nanica, por ser mesmo garnizé: mas apesar de retaca - isto agora é que é verdade! - qualquer moçona das mais sacudidas não lhe causaria inveja de qualidade alguma.

Pois o José das Perovas apaixonou-se perdidamente pela tal: não havia no quarteirão alma cristã que não soubesse do caso; por sinal que uma nhá Tuda, lingüinha levada dos dianhos, contara em segredo a muitas pessoas que o vira pinchar flores de baixo da janela pra riba, na casa em que a dita morava, com o pai quase imbecil por amor dos pifões.

O boato avolumou-se, daí a pouco. Raparigas houve que chegaram a perguntar à Nanica:

- Dizem por aí que você está dando corda ao filho do Manecão: é verdade? É verdade?

- Ora! O que têm vocês com isso? - tornava ela: tratem de sua vida e não se importem com a alheia, é o melhor! Eu nunca lhes perguntei por semelhantes coisas; façam o mesmo: não se intrometam em meus negócios.

Aquelas, contendo a raiva que lhes gritava no peito, nada mais lhe diziam na presença. Mas depois - virgem nossa senhora! - lá iam todos os qualificativos, em procissão, acompanhando o nome da outra: fogueta, namoradeira, sem modos, busca-pé, regateira, xingos deste porte, e de maior, alteavam-se aos ares, perseguindo-lh'o, quando acertavam de falar a respeito dela. A onda cresceu de modo que um dia a Nanica foi sabedora do que à sua conta rosnavam: olhou em redor de si, viu-se meio abandonada da sorte, aceitou de uma vez as galanterias do que havia tanto tempo a requestava - e um belo dia agarrou mundo.

A barulheira que correu no quarteirão, logo depois, nem se pode contar: parecia querer subir direitinho ao céu, de tão irada que vinha! Se não subiu é porque a voz do povo, em vez de ser de Deus, como alguns falam, é voz do diabo: e a voz do diabo não deve de passar deste

\footnotetext{
${ }^{56}$ Nota CLSD: "Correio Paulistano. São Paulo, $1^{\circ}$ set., 1895. (Escrito em Sta. Cruz do Rio Pardo)".
} 
inferno, que é a terra. Volvidos dias, porém, quietou o rumor; só o que se ouvia ainda eram conceitos como este:

- Aquilo é sina, coitada!

E por estarem convencidos de que era sina, deveras, aquilo, ninguém mais mordeu em o nome da pobre: no que andaram muito bem, porque afinal de contas águas passadas não fazem rodar moinho.

Um mortal não precisa de viajar grande coisa para achar a felicidade: às vezes (segundo afirma um entendido!), esta sujeita não está mais longe do que a dois passos da gente, e a gente vai procurá-la onde menos a pode encontrar! O José das Perovas não se afastou muito: arranjou seu rancho à beira do turvinho, aí pros lados do espírito santo, e dedicou-se à Nanica. E a Nanica dedicou-se-lhe que dava gosto vê-los.

De madrugada, ia ele ao trabalho, depois de dizer à companheira frases bonitas e maviosas como as do Armando Erse: ela escutava-o com semblante florido de regozijo, e retribuía-lhe os abraços. Entretanto, quando o vulto do José se sumia entre as duas guarucaias que se elevavam à margem da estrada, na garganta da mata, a moça principiava a suspirar, já de saudades. De tarde, ficava a esperá-lo à porta do rancho: e quando ele surgia, então ela dava de correr-lhe ao encontro, alegre que nem uma aleluia. Está-se vendo que vida melhor só no paraíso!

Mas o tempo dos frios chegou, anunciado desde o começo por umas ventanias bravas que acurvavam o lindo arvoredo dos arredores. Morreram as rosas do jardim do rancho. Os céus vestiram-se de cambraia, e a mata de luto. Daí por diante, dia a dia, caiu geada que foi um despotismo, consoante o falar dos caipiras vizinhos. A Nanica sentia-se intanguida: o próprio fogo das fogueiras como que já não esquentava. E como a pousada se erguia à boca de um vale, entre duas montanhas que pouco distavam uma na outra, o rugir do vento afunilado no vale era mais do que triste, doloroso. Ao aparecer o sol (que no dizer daqueles caipiras é o capote dos pobres), os dois amantes saíam a aquecer-se aos raios dele: no terreiro, ficavam separados, como se entre ambos se entendesse um lençol de água gelada. E as horas sucediam-se monótonas.

Uma vez, meado o dia, e na ausência do José , acercou-se do rancho um guapo moço, que teve para com a Nanica a mais requintada cortesia que se pode imaginar. Começou 
fazendo-lhe um cumprimento rasgado, ao estacar o cavalo pampa; achou-a depois, cativante; perguntou-lhe, depois, se aceitava umas violetas vivas, com o que ela muito se admirou, chegando a inquiri-lo:

- Adonde o senhor mora ainda há flores que não murcharam?

- Há, respondeu-lhe o guapo moço: não são tão bonitas como a senhora, mas enfim não têm nada murcho.

- E adonde é que o senhor mora, ainda que mal lhe pergunte?

- Pergunta bem. Não é longe, mas também não é perto demais.

A Nanica olhava-o meio de relance; percebeu que ele era um rico rapaz, porque num animal que encapotava a todo instante e, sobre encapotar, marchava com a cara virada de uma banda: os seus arreios luziam; suas caçambas eram de prata; seu bucal, outro tanto; o relho, a mesma coisa! Na garupa do pampa morria derradeira dobra de uma capa de veludo.

Com pouco apareceu o pajem, numa esperta mula ferreira, e o patrão meneou a rédea, para se ir ao caminho. Antes, porém, de o fazer, indagou:

- Se não fosse afoiteza minha, eu desejaria saber o seu nome.

Ao que ela respondeu:

- Nenhuma. Sou Mariana, sua criada, por apelido Nanica.

- Criada de Deus, que lhe dará bom pago.

Despediram-se: e foi só o que conversaram, naquela ocasião.

Não tardou, entretanto, que o guapo moço voltasse ao dito rancho, e à mesma hora. E como a nortada gemia de contínuo ao longo do vale, enregelando-o, a Nanica ansiou a deliciosa quentura de uma boa casa em povoada, e que lhe fora oferecida com alta gentileza: um dia, pois, abriu-se.

O José das Perovas por um bocadinho não enlouquece. Doeu-lhe aquilo tal e qual um golpe dos mais doídos. O amor que tinha era tão de raiz, que ali se deixou ficar uma temporada, no mesmo ninho, calculando que a Nanica talvez voltasse ainda. Ela, porém, não voltou nunca mais; o José fez-se ao largo afinal: e ao sair daquele retiro, onde os ventos, 
esbarrando uns nos outros, zuniam lamentosamente, uma porção de lágrimas se lhe foi derivando pelo rosto a fora.

Mas não há quem não saiba que tudo passa na terra. A sua dor, de funda que era, atenuou-se numa como surdina de saudades.

Voltou ao pândego viver de S. Domingos. E nos cateretês, de novo, não havia quem pudesse gabar-se de levar as lampas ao José: para sapatear com graça, ele estava apartado; para rasgar o pinho, como ele ninguém.

Quando, contudo, o bulício diminuía nas varandas das festas, quando os parceiros descansavam, o José das Perovas, a um canto qualquer, encolhia-se que nem um bico-de-latão ao cerrar da noite.

Seguido, acontecia que um dos folgazões o interpelava:

- Que diacho é lá isso, José? Você está a modos de jururu.

- Qual nada! Volvia ele ao outro: estou cansado, isso sim.

- Não está, não é: você o que tem é cócegas no coranchim por amor da Nanica.

- Juro que não é! Juro! Juro!

Assim lhe corria a vida, até o momento de se encostar aos travesseiros. Nesse momento, ao rezar, ele pedia a Deus perdão de haver jurado falso, e rogava-lhe:

- Senhor Deus de misericórdia! Já que esta paixa não me sai de dentro, ao menos fazei que a Nanica volte! Eu já não posso mais comigo, Senhor Deus de misericórdia!

Fosse pelo que fosse, um dia ela voltou!

O José das Perovas por um bocadinho não enlouquece. Arrodeava a ingrata arrependida, meigo nas mãos, na voz e nos olhos. E como a Nanica desse de chorar, de pura comoção, ele enxugava-lhe as lágrimas, carinhosíssimamente. Ficou tão possuído de alegria que chegou a resolver:

- Hoje havemos de dançar um baile às direitas, pois não havemos, meu amor?

- Seja tudo como você quiser - gorgeou ela.

Mandou-se chamar o Romão, sanfoneiro endemoninhado que assistia pertinho, combinou-se tudo, e o baile principiou quando a noite principiou. 
Lá pelas tantas horas, ouviu-se um tropel de cavalos na rua, que veio morrer mesmo à porta do pagode. O José das Perovas apareceu a receber quem quer que era, ao que lhe perguntaram do lado de fora:

- Não está aqui uma moça conhecida por Nanica?

- Está. Para quê? - interrogou o José.

- Porque eu e mais o camarada viemos buscá-la.

- Então entrem, entrem.

Logo que eles entraram, o José das Perovas tomou dum refle que tinha, em cujo manejo era mestre, e ordenou:

- Agora vosmecês hão de mas é dançar conosco.

E não houve outro jeito. O guapo moço, xavi que nem um gambá torrado, teve que fazer pé de alferes a noite inteira, e seu pajem também.

Assim que arraiou o dia, o José das Perovas falou-lhes:

- Podem-se ir agora, vão-se e não se lembrem mais de aprontar outra!

Eles não se lembraram até hoje: e o José e a Nanica vivem felizes e juntinhos, tal e qual um par de vevuías.

Se no meio de uma prosa alguém acerta de recordar o nome deles, há uma pessoa que se não esquece de dizer:

- Vejam só que força não tem o primeiro rabicho! 


\section{Análise do conto}

"Jurando falso" apresenta uma certa erudição por parte do narrador. Nos diálogos podemos encontrar o coloquial culto (refreada um pouco a erudição).

O conto tem como tema a superação, por parte de Perovas de uma traição amorosa. Nos diálogos podemos perceber a presença de vários regionalismos ou brasileirismos, na acepção de Aurélio Buarque de Holanda Ferreira em seu Novo dicionário Aurélio da Língua Portuguesa (ed. cit.).

O termo brasileirismo, empregado por Aurélio Buarque de Holanda, é bem apropriado para designar o que significa um regionalismo, pois, no fundo, este se constitui em um brasileirismo, na medida em que as palavras e expressões típicas de uma certa região fazem parte de um todo que é o território brasileiro. Assim, os dois termos chegam a se confundir em sentido. Contudo não nos cabe aqui, neste breve espaço analítico, entrar em pormenores a respeito da conceituação lingüística e gramatical do que vem a ser um brasileirismo ou um regionalismo. Fica estabelecido nesta análise, porém, que optamos, por razões práticas, pelo termo regionalismo.

Abaixo, como exemplo de emprego de regionalismos no conto, segue um diálogo entre "um dos folgazões" e José das Perovas, diálogo no qual grifamos os dois regionalismos:

“- Que diacho é lá isso, José? Você está a modos de jururu ${ }^{57}$.

- Qual nada! Volvia ele ao outro: estou cansado, isso sim.

- Não está, não é: você o que tem é cócegas no $\underline{\text { coranchim }}^{58}$ por amor da Nanica”.

Pelos exemplos acima, temos uma pequena amostra do que é o registro do falar caipira, que comporta expressões típicas de um mundo com regras bem particulares de conduta. Uma dessas regras é a de não violar os preceitos divinos, sob a pena da punição na terra. Isso causa

\footnotetext{
${ }^{57}$ Segundo FERREIRA, Aurélio Buarque de Holanda. Op. cit., p. 996, jururu, do tupi xearu'ru, que é 'estar tristonho", é um brasileirismo que quer dizer "triste, melancólico".

${ }^{58}$ De acordo com FERREIRA, Aurélio Buarque de Holanda. Op. cit., p. 477, coranchim é um brasileirismo muito corrente no estado de São Paulo e é o mesmo que curanchim (op. cit., p. 511), que por sua vez é o mesmo que uropígio (op. cit., p. 1742), termo da Zoologia que significa "apêndice triangular sobre as últimas vértebras das aves, no qual se implantam as penas da cauda [Sin., pop.: sobrecu, sobre, mitra e (bras.) sambiquira, curanchim, micula.]".
} 
medo a quem quebra qualquer juramento sagrado, como podemos abservar na passagem abaixo:

"Assim lhe corria a vida, até o momento de se encostar aos travesseiros. Nesse momento, ao rezar, ele pedia a Deus perdão de haver jurado falso, e rogava-lhe:

- Senhor Deus de misericórdia! Já que esta paixa não me sai de dentro, ao menos fazei que a Nanica volte! Eu já não posso mais comigo, Senhor Deus de misericórdia!"

José das Perovas, sofrendo a dor de amor pela perda de Nanica, pede a Deus para que Ele a traga de volta, o que acaba acontecendo.

Há no conto, como nos anteriores, fortes marcas românticas nos diálogos e, também, na narração, quase toda construída no falar caipira. Há uma forte aproximação entre o narrador e as personagens, em termos do uso do falar caipira, proporcionando um grau maior de realismo no conto, o que nos leva a pensar nas reflexões de Lukács ${ }^{59}$. Esta aproximação não chega a ser total, pois o narrador usa algumas expressões do coloquialismo culto, tais como: "frases bonitas e maviosas", "semblante florido de regozijo", "retribuía-lhe os abraços", "dava de correr-lhe ao encontro", entre outras.

Seguindo o raciocínio de Georg Lukács, quanto maior for o teor de realismo de uma obra literária, mais ela tende a cumprir a função social de chamar a atenção do leitor para uma determinada situação social (freqüentemente de opressão de um grupo ou sujeito economicamente mais forte perante outro mais fraco), proporcionando a conscientização política deste leitor. Há, portanto, um componente ideológico marcante no pensamento lukacsiano. No conto, o teor de realismo que a aproximação da fala do narrador com a das personagens promove é, ao invés de denunciar uma dada situação de opressão social, chamar a atenção para uma questão de ordem moral e religiosa: o comportamento de Nanica. É assim que o narrador a descreve logo no início do conto:

"Dizer o que era a Nanica, nos tempos em que o José das Perovas pegou de amores com ela, é coisa quase impossível: só mesmo se se lhe visse o retrato é que se convenceria a gente da formosura perigosa que a diaba tinha. Chamavam-lhe Nanica, por ser mesmo garnizé: mas apesar de retaca - isto agora é que é verdade! - qualquer moçona das mais sacudidas não lhe causaria inveja de qualidade alguma”.

\footnotetext{
${ }^{59}$ LUKÁCS, Georg e outros. Realismo, materialismo, utopia. Lisboa: Moraes, 1978.
} 
Alguns excessos românticos e sentimentais presentes no conto reprimem o aprofundamento de questões políticas, sociais e morais (estas, por sinal, são as que mais saltam aos nossos olhos) que estão por trás dos acontecimentos narrados. Um bom exemplo é a passagem abaixo:

"De madrugada, ia ele ao trabalho, depois de dizer à companheira frases bonitas e maviosas como as do Armando Erse: ela escutava-o com semblante florido de regozijo, e retribuía-lhe os abraços. Entretanto, quando o vulto do José se sumia entre as duas guarucaias que se elevavam à margem da estrada, na garganta da mata, a moça principiava a suspirar, já de saudades. De tarde, ficava a esperá-lo à porta do rancho: e quando ele surgia, então ela dava de correr-lhe ao encontro, alegre que nem uma aleluia. Está-se vendo que vida melhor só no paraíso!"

Expressões como "frases bonitas e maviosas", "semblante florido de regozijo", "a moça principiava a suspirar, já de saudades", "alegre que nem uma aleluia" e "vida melhor só no paraíso!", excessivamente sentimentais, ao nosso ver, deturpam e, até mesmo, empobrecem esteticamente, socialmente e ideologicamente o texto. Porém, o esforço de aproximação e adequação (não de todo bem realizado) da fala do narrador com a das personagens caboclas, promovendo um significativo teor de realismo no enredo, é louvável. 


\section{$\underline{\text { Mutirão }}^{60}$}

Tovaca das grandes já cantou na mata-virgem, surucuá do peito amarelo já deu seus garganteados lá para as bandas do morro, e o sol está sai-não-sai. Faz um tempo de encantar. Nhô João da Grota, que é quem mais madruga por estes cafundós, já andou corre-correndo a invernada, para tocar as vacas pro curral, e está de volta, com o nariz vermelho por causa do frio; dendem, sua mulherzinha, pequetita e franzina, mas engraçada que em uma maravilha das mais miúdas, aprontou o chá de congonha e ficou esperando-o.

Assim que ele apontou, dendem botou a bandeja de chá com broinhas de fubá mimoso em riba da mesa; e enquanto o bule ainda está abafado, para ficar bom às direitas, ela vai arranjar um picuá com virado de galinha, porque nhô João da Grota convocou mutirão ${ }^{61}$ para uma derrubada. Ele chegou, entrou, sentou-se junto à mesa, e pegou a tratar de adquirir sustância para serviço até a hora do almoço; e nem bem acabou de bater a última broinha e engolir a derradeira xícara de chá, foi, renteando com a cerca, olhar se as vacas estavam comendo as espigas de milho do costume; depois, voltou, garrou o picuá e a ferramenta, e abalou para o espigão da derrubada.

\footnotetext{
${ }^{60}$ Nota CLSD: "O Repórter. São Paulo, 3 jan., 1896. (Escrito em Sta. Cruz do Rio Pardo)".

${ }^{61}$ Nota da edição: SOUZA, Bernardino José de. Op. cit., p. 226, a respeito de mutirão, diz: "vide Muxirão. 'Toda a redondeza falou no caso e, sobre ele, Joaquim Piaba fez uma versalhada que se repetia em cantigas, nos eitos e mutirões...' (José Sizenando. Alma rústica, p. 10). Com este nome se conhece o mesmo fato em Santa Catarina: mutirão ou muxirão. Descrevendo-o no Município do Rio do Sul em Sta. Catarina, relata o Sr. Pedro Paulo Cunha em o $\mathrm{n}^{\mathrm{o}} 46$ do Serviço de Informação do Dep. de Estatística do Estado: 'O mutirão representa o auxílio gratuito, prestado por várias pessoas ao proprietário de certa coisa. Assim, se um colono precisa construir uma casa ou fazer uma grande roçada, convida os amigos da redondeza, que em geral são 20 ou 30 homens e ali reunidos trabalham todo o dia, fazendo grandes serviços sem despesas financeiras para o proprietário, correndo este apenas com as refeições. À noite é organizada uma festa na casa do colono favorecido, e uma lauta ceia regada a vinho e outras bebidas. Segue-se um baile que se prolonga até altas horas da noite, ao som da gaita de mão e do pandeiro'. A respeito de muxirão (op. cit., p. 226-227), verificamos que é um termo 'registrado por quase todos os vocabularistas brasileiros no sentido de concurso gratuito de muitos trabalhadores para algum serviço, ou como disse Amadeu Amaral - 'reunião de roceiros para auxiliar um vizinho nalgum trabalho agrícola - roçada, plantio, colheita, terminando sempre em festa, com jantar ou ceia, danças e descantes'. Numerosa sinonímia apresenta este termo: assim é que, no Rio Grande do Sul, se diz também pixurum, puxirão, ajutório; em partes de Minas - mutirão e bandeira; na Bahia e em Sergipe - batalhão, ajutório; no sueste da Bahia - boide-cova; em S. Paulo - corte; em Pernambuco - adjunto; na Paraíba - bandeira; no Pará - potirom, puxirum, mutirum; em Goiás - muxirão, mutirão, muxirum. Há dúvidas quanto à etimologia do vocábulo muxirão, sendo provável derivar-se do guarani - potyrom que, segundo Montoia, significa pôr mãos à obra. Teodoro Sampaio deriva-o do tupi - puchirô - o socorro, o auxílio, a ajuda, o que bem concorda com essa junção de esforços dos sertanejos do Brasil. No Amazonas diz-se ajuri - a reunião e ajuricaba - o trabalho confraternizado e o tempo para esse fim. Era prática dos ameríndios, chamada pelos quíchuas - minga (Pe. Gusman) e pelos caboclos do Oiapoque - mahurê".
} 
Agora o sol já mostrou um ar de sua graça; uns fiinhos de luz riscaram as montanhas. A passarinhada gorgeia que é um Deus nos acuda. Os piripixios, revoando dois a dois por cima dos carurus amadurados, não têm mais propósito e pintam a manta; têm sabiás os arvoredos, que a gente chega a perder a conta deles; tirivas grasnam poderosamente; saíras pulam, bicando as frutas. Um tucano dos grandes, num vôo vagaroso e cheio de importância, acaba de passar pelo meio da passarinhada, sentou um galho de juvévé; olhou de roda, e como está fomento, desceu a uma fruteira.

Nhô João da Grota ouvia tudo e nada via; baixava o olhar ao chão e ruminava projetos e mais projetos; a madeira que estava jurada de cair, daria um tanto; a lenha, outro tanto quase; e depois, quando estivesse tudo escampo, havia de plantar uns dez mil pés de café; quando o café pegasse a dar, - então, Jesus! - não haveria mãos a medir. Já tão longe deste mundo, que não percebeu a meia risada que os parceiros do mutirão soltaram, ao vê-lo passando arcado e banzando de tal jeito no sossego do caminho. Afastara-se bastante de casa, fronteava uma capaúva grandalhona, quando ouviu a voz do Maneco Furquim, que isto dizia:

- Nhô João! Ó nhô João! Espere a gente! Já se acha tão rico e soberbo que nem vê os pobrinhos?

Ficou enleado e sem ter coisa que servisse de resposta. Voltou-se para os lados de onde rompera a voz, e qual não foi o seu espanto, ao notar que a companheirada vinha ali, tendo-o por certo visto passar! E ele não a vira! Até gaguejou. Foi-se repondo, entretanto, pouco a pouco, a ponto de caçoar com os caboclos, atirando-lhes pilhérias cheias de afeto. A um chamava araponga, porque o via com a cabeça branca, branca; a segundo, que ladeava este, graúna, por ter pelo contrário o coco preto, preto; a outro, paca das mais guasqueiras, por andar ainda àquela hora, meia do dia, meia da noite. E as gargalhadas espalhavam-se no seio quieto da mata por onde seguiam.

O frio estava tinindo! Cada qual trazia seu ponche, seu chale-manta, sua japona, seu pala; e como de prevenção cada qual trouxera também os pés bem enfiados em sapatos ou tamancos, o rumor que levantavam, andando e gargalhando, parecia o de uma tropa de potros que estivesse a correr e relinchar por uma invernada - sem comparar uma coisa com a outra! O Chiquinho Gázeo, que dava mostras de ser o mais friento de todos, até batia a fila de dentes de cima com a de baixo, semelhando um sujeito amaleitado; o Rufino, magricela por amor de uma asma que nunca o largava, ia dizendo suas frases com a voz meio encoberta pela pieira; os demais nada diziam. 
Apareceu o valo que marcava o princípio das terras de nhô João. Beirando-o desde a cerca de varas, chegava-se a uma aguada que as taiovas escondiam pela metade; era aí que devia de começar a forte lida. Chegados, pois, nhô João pôs à vista de todos uma bojuda garrafa de caninha, daquelas que fazem a gente vidrar os olhos, de tão gostosa; e, um por um, deram sua boquinha no gargalo. Afiaram as foices, só por luxo, porque elas vinham finas de véspera, experimentaram os machados, e o capitão do bando berrou:

- Um! Dois! Três!

À terceira palavra, a foiçaria desceu direito. Aquilo é que era zé-povinho cumba pro serviço! Tudo batia num só compasso, e firme até ali. Podia-se ouvir facilmente, numas cem braças em redor, o pausado resfolegar de todos os peitos; e o matinho baixo, então, mais se baixava, como por encanto, acumulando-se em pequenos feixes que erguiam ao ar a brancura igual das hásteas cortadas. Daí a nada, também, já estava tudo raso. Chegou-se ao matão feio. O garrafão de caninha andou outra vez de déu em déu. Sumiram-se as foices e os machados apareceram. E a forte lida continuou na mesma toada que dantes; com a diferença que agora, numas quinhentas braças em redondo, se poderiam ouvir as crebras machadadas. Alguns passarinhos protestavam, gritando, contra aquela invasão; mas ninguém dava fé, sequer, de tamanha e tão tola arrelia.

A espaços, vibravam dentre o barulho pedidos como este:

- Mané Guarirova, canta uma moda!

- Uma moda bem terna, Mané Guarirova!

- Bem chorosa!

- Bem tremida!

O Mané Guarirova, fazendo-se surdo, prosseguia no trabalho, com afã. Quem o visse tão absorvido na lavra, mostrando-se mourejador como poucos, não seria capaz de adivinhar que ali se achava o cabra mais entusiasmado dos cateretês. Por isso mesmo lhe rogavam que cantasse. Os que rogavam não perderam seu tempo; a voz bonita daquele danado alteou-se regaladamente, com intervalos curtos regulados ao lascar das madeiras. A primeira moda foi assim:

“Tico-tico lari no quilão, 'tá batendo c'o bico no chão, andorinha fazendo verão, 
por isso é que eu sempre digo:

querer bem não é bom, não,

ai!

querer bem não é bom, não!"

- Essa não serve, Guarirova! - lhe disseram, logo que terminou a trova.

- Por quê? - inquiriu ele.

- Porque é moda do norte, e aqui não há ninguém de lá.

- Então boto outra.

E de fato cantou por esta forma:

$$
\begin{aligned}
& \text { "Vai serrar pau de pinho } \\
& \text { e também de canela, } \\
& \text { pra fazer cinco portas, } \\
& \text { vinte e cinco janelas; } \\
& \text { pra matar a saudade, } \\
& \text { que eu não posso mais co'ela: } \\
& \text { puxa a serra, Mariana! } \\
& \text { puxa a serra, Mariana!" }
\end{aligned}
$$

- Essa também é do norte, não serve! Foi o que lhe observaram.

- Pois do norte sou eu - rotorquiu ele; e sirvo muito!

- Olhem só a prosa!

- Pois se vocês bem sabem!

- Está bom. Cante uma modinha.

- Como coisa que sou agora algum sabiá. É cantar e mais cantar! Quem tem boca...

- Vai a Roma.

- ... Não manda soprar, que ainda é melhor e mais importante.

Entrementes o sol fora subindo, subindo; já seus raios caíam direitinho sobre os troncos das perovas, de alto a baixo, o que vale dizer que podia ser meio-dia. A caboclada suava à grande: o próprio guarirova, destemido como raros, já tinha a testa orvalhada e a camisa de meia pingando. Nhô João da Grota convidou tudo para o almoço, o que foi uma idéia esplêndida, pois ninguém mais bateu machado nos arvoredos. Agruparam-se os parceiros à roda dos caldeirões enormes, que 
fumegavam cheirosamente, e era de ver o jeito aforçurado de cada qual. Levantavam-se afirmações deste teor, a todo instante:

- Arre! Que já não posso mais!

- A fome é negra e maligna, nhô João da Grota !

- Estou com o rato no paiol, nhô João!

- Nhô João, quase morro de fraqueza!

Houve tempo e lugar para todas as coisas. Queixas não apareceram; muito pelo contrário, quando nhô João trouxe nova carregação de pinga, da tal que fazia vidrar os olhos vários corações agradecidos não se puderam conter:

- Mas você é um anjo, nhô João!

- Nhô João, você é um demônio tentador!

E outros e outros ditos, ao fim dos quais veio o café com mistura. Biscoitos, brevidades, bolos de arroz, o que de melhor se imagina para sobremesa de almoço, nada faltou naquele. Ao erguerem-se todos, cheios e fartos, não foram poucos os que sentiram bambas as pernas. $\mathrm{O}$ que logo passou, afinal, porque, por amor do serviço, ninguém quis quebrar as munhecas às direitas. $\mathrm{E}$ todos andaram, cantando:

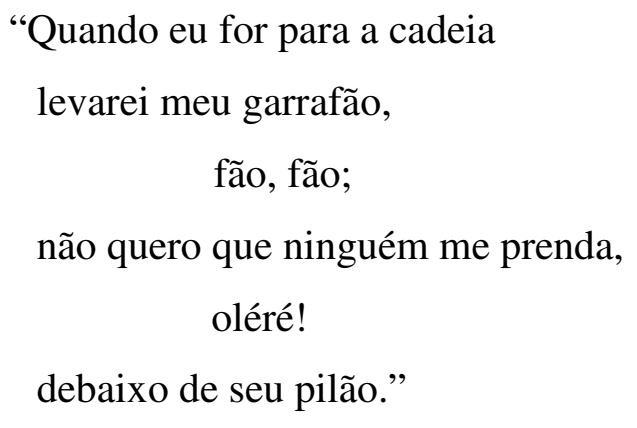

A faina continuou como dantes. Guarucaias, vamirins, tapiás, caneleiras, corações, canjaranas, iam caindo uma a uma todas as árvores do espigão. Apenas uma tira, nada mais, restava para derrubar; e quando foi três horas, se tanto! - o alto do morro surgiu, embranquecido dos troncos que patenteavam lascas recentíssimas. Nada mais! Nada mais! - e a parceirada, juntando a ferramenta, reuniu-se a repousar, entre dois canchins grossos. $\mathrm{O}$ sol tremia no céu, quente e bravo; mas ali no meio das ramarias ainda verdes, havia uma frescura de encantar.

O Maneco Furquim, pegando do garrafão, cantou: 


$$
\begin{aligned}
& \text { "Viva o cravo, viva a rosa, } \\
& \text { viva a flor de maravilha, } \\
& \text { viva o nosso João da Grota } \\
& \text { e toda a sua família!" }
\end{aligned}
$$

A parceirada acompanhou, firme na toada. Depois, como estava tudo feito, cada qual tratou de abalar para seus pagos: o grupo desceu do morro, alegre que nem um bando de araguarís em fruteira, e nhô João da Grota vinha mais alegre do que todos.

Ao chegar à casa, sozinho, que os companheiros se tinham espalhado para diferentes rumos, falou à dendem, que labutava risonha e corada como uma aurora:

- Agora, sim, podemos esperar nossos filhos sem susto; o nosso futuro lá está, naquele espigão.

E aproximando-se dela, ainda mais, falou-lhe ao ouvido:

- Não precisamos agora de estar fugindo das luas! 


\section{$\underline{\text { Análise do conto }}$}

"Mutirão", de 1896, apresenta o coloquial narrativo e o diálogo, ora em falar caipira, ora em coloquial culto.

O narrador faz uso de algumas palavras e expressões correntes no mundo caipira, tais como "cafundós", "garrou", "para as bandas" e "Deus nos acuda".

As expressões do mundo caipira, em contato com a linguagem regional das personagens, proporcionam um discurso (tanto do narrador quanto das personagens) híbrido, mistura da linguagem coloquial culta do narrador, com a linguagem coloquial sertaneja, da qual resulta um discurso mais ou menos homogêneo. De certo modo, esse discurso homogêneo "nivela o discurso do narrador com o da personagem, por meio da amenização de alguns acentos característicos das duas falas: a culta e a rústica", conforme a estudiosa de Valdomiro Silveira ${ }^{62}$.

Podemos observar a mistura das linguagens no primeiro parágrafo de "Mutirão":

“Tovaca das grandes já cantou na mata-virgem, surucuá do peito amarelo já deu seus garganteios lá para as bandas do morro, e o sol está sai-não-sai. Faz um tempo de encantar. Nhô João da Grota , que é quem mais madruga por estes cafundós, já andou corre-correndo a invernada, para tocar as vacas pro curral, e está de volta, com o nariz vermelho por causa do frio; dendém, sua mulherzinha, pequetita e franzina, mas engraçada que nem uma maravilha das mais miúdas, aprontou o chá de congonha e ficou esperando-o".

No trecho acima, as perífrases se constituem em elemento determinante para o rebaixamento do tom erudito da narração, "num esforço de transição harmônica para o dialeto, que desta forma não é realçado" ${ }^{63}$, segundo Carmen Lydia de Souza Dias, que usa a palavra dialeto e não a expressão que hoje vigora: falar caipira.

Em "Mutirão" há palavras formadas através do processo de composição da justaposição. Alguns exemplos são: "mata-virgem", "sai-não-sai" e "corre-correndo". Este processo também foi muito utilizado, anos depois, por Mário de Andrade em Macunaíma e Guimarães Rosa em suas obras. A propósito de Guimarães Rosa, é possível que Valdomiro Silveira o tenha influenciado em boa medida na escritura regional e universal de suas obras.

\footnotetext{
${ }^{62}$ DIAS, Carmen Lydia de Souza. Op. cit., p. 185.

${ }^{63}$ Op. cit., p. 185.
} 
$\underline{\grave{A} \text { hora da prisão }}^{64}$

Sempre foi uma atroada, a mulher do Silvano. Bonita, isso então era até ali, mas até ali também ia a falta de juízo e parava. Nunca se viu coisa semelhante nos arredores! Moravam no capim, e a Brígida - foi o nome que lhe deram à pia do batismo - vivia entre os dentes de meio mundo: não havia quase quem não tivesse qualquer coisa a dizer de mal da mesma. As mulheres tinham-lhe uma jeriza danada, e falavam de raiva ou ciúmes; os homens falavam por falar; e saíam horrores a respeito dela.

Antes de se fechar o trato do casamento, avisaram ao Silvano que não caísse desse cavalo; raparigas formosas não faltam, agora o que não é muito fácil é o encontrarem-se formosas que o mesmo tempo sejam honestas e trabalhadeiras. Ora ninguém ousaria clamar contra a honra da Brígida, que andava guardada às sete chaves dos cuidados da mãe: mas, enfim, que diabo? - uma criatura que, quando vai ao arraial, está só voltando a cara pra trás e reparando em quanto moço vê, não pode ter muito pano na carapuça, e deste modo procedia ela.

O Silvano parece que não deu fé: se désse fé, teria antes pedido a Deus um bom morrer! A uns e outros retorquiu que a Brígida, por morar num fundo de roça, ficava curiosa, em chegando ao povoado, e pegava a atentar em todos os desconhecidos - moços e velhos, bem-compostos e feios. E também ela não lhe jurara amor ainda, e por consequiência podia olhar a quem mais lhe aprouvesse. Teimou, bateu pé, e casou-se.

Não lhe tardaram os desgostos. A mulher, falando com certos sujeitinhos meio pelintras da redondeza, mudava completamente de tom; a voz tornava-se-lhe mais vagarosa, o olhar mais quebrado, o gesto mais cheio de fogo; tinha algumas conversas pouco permitidas à gente séria, uns risos escancarados, um andar bambo e provocador. Aparecendo-lhe um folgazão dos de fama, em casa, aceitava logo convite para cantarem modas, e ali em presença do Silvano ferravam direito na toada; mas afinal aquilo tudo tinha jeito de não ter segundas intenções, porque era tão inocente, e o Silvano ia agüentando.

Saiu um dia para São Pedro do Turvo, e nesse dia voltou, vindo encontrar em casa o Ernesto Carreiro, que corria como antigo namorado da Brígida. A prova que estavam tendo nada mostrava de ruim; porém não gostou de ver o Ernesto em casa, sabendo às claras, que

\footnotetext{
${ }^{64}$ Nota CLSD: "O Repórter. São Paulo, 10 jan., 1896. (Escrito em Sta. Cruz do Rio Pardo)”.
} 
ele durante muito tempo arrodeara a moça, com pouca resolução e coragem de pedí-la em casamento: não gostou, mas nada tugiu, fez cara alegre para o Ernesto e para a Brígida e tudo assim ficou.

Chegara-se ao fim de dezembro. Apesar de umas chuvas que de quando em quando caíam, o Silvano continuou no serviço de cinco alqueires de roça que empreitara: afastava-se do rancho à ruiva do amanhecer e voltava à ruiva do sol posto, porque era um mouro para o trabalho. Um dia, como de novo achasse de prática a mulher e o Ernesto, e logo que este se foi, falou à Brígida, com toda a brandura e amor, que evitasse tais visitas quando ele estivesse fora. Não duvidava de sua querida mulherzinha (e afagava-a), mas enfim ela não desconhecia que o Ernesto a namorara no passado, e havia muita língua má no mundo que seria capaz de inventar baixezas e dizê-las à conta dela.

Aquilo foi um tempo quente! A Brígida fitou nele uns olhos queimantes de fúria; não fosse tirá-la à mãe, se desconfiava dela! Conhecia ao Carreiro desde pequenina, pois era muito mais criança que ele, tinha muita liberdade, mas cada qual sabia do seu lugar. O Silvano, ao vê-la iracunda assim (que ela então se tornava mais tentadora do que nunca), nada mais fez do que beijála, abraçá-la, cobrí-la de festinhas, prometendo-lhe que não lhe tocaria, de futuro, em tais amofinações. Ela ameigou o semblante, chorou seu pouco, e ele também não deixou de sentir os olhos um tanto aguados.

A noite do Natal rompeu linda que dava para encantar. São Pedro é longe, por isso quase ninguém assistiu à missa do galo; mas o Zequinha Floriano fez uma reza, e depois da reza havia de haver um fandango. Houve o fandango - dos que são capazes de deixar um soalho partido! - e o Silvano e a mulher estiveram rentinhos. Nem bem escureceu, já o povo principiou a aparecer; até hoje muitos se recordam da quantidade de violas que se via naquela função ${ }^{65}$, e ficam admirados.

O Ernesto era triste para rasgar o pinho, cuera de verdade! Em se lembrando alguém dalgum divertimento, ouvia logo a recomendação:

- Não vá faltar o Ernesto Carreiro!

E não faltava em pagode nenhum, o dianho, não faltava. Todos o queriam para animar as reuniões; mutirão em que ele não estivesse, perdia metade do valor, e a moçada fugia de tal mutirão, de modo que o serviço perigava. Agrados e carinhos, todos os faziam ao malvado, e

\footnotetext{
${ }^{65}$ Nota da edição: Segundo FERREIRA, Aurélio Buarque de Holanda. Op. cit., p. 819, função é um brasileirismo que significa "festa dançante; baile, dança: 'Fora, ... o camarada assobiava enternecido uma tirana das derradeiras funções.' (Valdomiro Silveira, Os caboclos, p. 70-71.)". Função também pode ser um outro brasileirismo, significando "pândega, divertimento, funçanata. [Var., bras., pop., nesta acepç.: fonção.]". Pelo contexto de "À hora da prisão", consideramos mais adequado o sentido de "festa dançante; baile, dança".
} 
ele ia só serenando no bairro do capim, lisonjeado com tanta contemplação. Foi, pois, à reza do Zequinha Floriano, depois de haver tomado uma cabriúva ${ }^{66}$, para limpar a garganta, e ninguém teve coragem de cantar antes dele; também, que voz macia nosso senhor lhe dera, que voz!

A Brígida, logo que o viu de lenço de setineta no pescoço, flor no chapéu novo, lacinho de fita de nobreza na viola, não sossegou mais. Olhava um minuto ao marido e meia hora ao Ernesto; quando este agarrou a cantar, ela sentiu-se amolentada da cabeça até os pés e pegou a apanhar laranja, até no sapateado; o Silvano, que era seu parceiro no fandango, pediulhe que reparasse na dança e não errasse daquele feitio. E muito embora forcejasse por ter paciência, o coitado estava com uns apertos no coração, que lhe doíam demais; houve um instante, quando estavam dando a volta, em que rogou à mulher, pelo amor de Deus, que não o atormentasse e fugisse de chocar tanto o folgazão. Ela deu no corpo um galeio de enfado, e continuou no mesmo sistema.

O Silvano estava de peito cortado: fazer-lhe a Brígida tamanha ingratidão, à vista do pavaréu, foi coisa que o deixou louco de tristeza e de zanga; apesar de ser um rapaz assentado, e não ter por costume virar, aproximou-se da dona da casa, logo que a primeira moda se acabou, e pediu uma queimada. Bebeu quase um martelo, duma vezada só; daí a pouco rugiam-lhe os ouvidos, as pálpebras tornavam-se-lhe preguiçosas e um enorme desejo de vozear alto como que o engasgava; ao em vez, porém, de fazer alarido e praguejar, sentou-se a um canto da sala, contemplativo, e pôs-se a pitar um cigarro que não tinha fim.

Nessa ocasião, o Bertoldo, também cantador afamado, empunhou a viola e disse:

- Companheirada, vamos tirar outra irara!

Todos se foram juntando, e as de saia eram as mais influídas. A Brígida, convidada pelo Ernesto Carreiro e sem consultar ao marido, ficou à frente do antigo namorado, como uma das primeiras. O Bertoldo gargarejou uma das modas pândegas e chulas que sabia, e o palmeio parece que começou num frenesi de loucura. O Silvano, então, pinchou ao largo o cigarro de macaia que não se acendia, e perfilou o tronco; o olhar queimava-lhe; as mãos tremiam-lhe; a sala como que se esvaziara, ficando apenas, para ele, a mulher e o maldito Carreiro...

\footnotetext{
${ }^{66}$ Nota da edição: Segundo FERREIRA, Aurélio Buarque de Holanda. Op. cit., p. 304, cabriúva, no contexto da frase onde se encontra em "À hora da prisão", é um brasileirismo que significa uma "certa bebida feita com açúcar, gengibre e aguardente".
} 
Depois, quando os viu falar assim de certo jeito, um à orelha do outro, no meio mesmo da dança não pôde conter-se mais: levantou-se que nem uma fera, puxou da cinta a garrucha fulminante, aproximou-se do rival e desfechou-lhe um tiro à queima-roupa. $\mathrm{O}$ tiro varou o queixo do Ernesto Carreiro, que foi caindo ao soalho, numa lagoa vermelha. O Silvano atirou a garrucha para o canto em que estivera, e pôs-se a remirar a Brígida, como se nada tivesse acontecido; e vendo-a branca tal e qual a cal da parede, as lágrimas deram de lhe correr pela cara abaixo, aos pares. Um silêncio terrível se fizera.

O Zequinha Floriano, rompendo da cozinha, intimou-lhe:

- Está preso à ordem do subdelegado!

Cercaram-no quase todos os caboclos, amarraram-no, magoaram-lhe as carnes: e ele, apatetado e lerdo, parecia não compreender o que lhe estavam aprontando. Assim, porém, que o mandaram sair, para ser conduzido à cadeia de S. Pedro, uma dor cruciante como que lhe tomou a garganta inteira. Soluçou que nem um perdido, que nem um louco, e ao ver a mulher, que de longe o espiava, aterrorizada e pálida ainda, gritou-lhe:

- Você perdoa, Brígida, você perdoa? 


\section{$\underline{\text { Análise do conto }}$}

"À hora da prisão" trata do tema da violência que envolve um triângulo amoroso. No final do conto, a personagem Silvano atira e mata Ernesto Carreiro por ciúme de Brígida, mulher de má reputação na comunidade em que vivia.

A violência é tratada em um ambiente de lazer, em uma "função". Podemos observar no conto que a violência do ato de Silvano está fortemente ligada à moral, tanto no que diz respeito à honra que se prende, na situação narrada, ao ciúme e ao ódio, a qual não exclui um certo componente religioso 67 . A expressão "guardada às sete chaves dos cuidados da mãe" carrega uma referência bíblica, e portanto ligada à moral cristã, muito importante na referência a "sete chaves". O número sete é recorrente em várias passagens da Bíblia como no princípio do Gênesis, o primeiro livro de Moisés, do Velho Testamento, que faz alusão à criação do mundo por Deus. O segundo capítulo do Gênesis, versículos um e dois, afirma que Deus terminou de fazer "os céus, a terra e todo o seu exército" 68 no sétimo dia e depois descansou, nesse mesmo dia, de todo o seu trabalho.

As brigas provocadas por ciúme, rivalidade entre homens no trabalho, alcoolismo, exclusão social e ofensa à honra e à moral de uma pessoa, eram constantes à época da escritura do conto. Incluíam também a questão do adultério ${ }^{69}$. Esta questão envolvia a defesa da honra familiar, ligada fortemente à estrutura patriarcal e machista da sociedade rural do final do século xix. A moral naquela sociedade era tão rígida em torno dos valores patriarcalistas que até mesmo a lei se colocava, na maioria das vezes, ao lado de quem cometia um crime defendendo a honra de sua família.

O conto é narrado em terceira pessoa e apresenta poucos diálogos entre as personagens. A narração é feita de modo coloquial culto e os diálogos aparecem ora no falar caipira ("Companheirada, vamos tirar outra irara!”), ora em coloquial culto (“Está preso à ordem do subdelegado!").

\footnotetext{
${ }^{67}$ A respeito do tema da religiosidade no sertão, consultar QUEIROZ, Maria Isaura Pereira de. O campesinato brasileiro. $2^{\mathrm{a}}$ ed. Petrópolis: Vozes, 1976.

${ }^{68}$ A Bíblia Sagrada.. Trad. das Línguas Originais por João Ferreira de Almeida. 10a impr. Deerfield: Editora Vida, 1996. p. 2.

${ }^{69}$ Em "O código do sertão", Maria Sylvia de Carvalho Franco relata um caso de adultério que acaba na morte do "ofendido" por parte do "ofensor" e no julgamento do delito (Homens livres na ordem escravocrata, p. 46).
} 
É interessante notar que a palavra "função" não é empregada com o sentido mais usual, ou seja, com o de utilidade ou serventia. Na estória, "função" designa festa. No contexto histórico-cultural retratado no conto, a "função" supõe um rito, transmitido e repetido, de natureza quase obrigatória:

"Houve o fandango - dos que são capazes de deixar um soalho partido! - e o Silvano e a mulher estiveram rentinhos. Nem bem escureceu, já o povo principiou a aparecer; até hoje muitos se recordam da quantidade de violas que se via naquela função, e ficam admirados”.

"À hora da prisão", por ser um conto quase que totalmente narrado em terceira pessoa e com pouquíssimos diálogos, é relativamente longo e, segundo Carmen Lydia, pode ter sido considerado por Valdomiro Silveira "apenas como repositório do "caso" para futura reelaboração" ${ }^{, 70}$. Isso parece demonstrar, ainda segundo aquela autora, a decorrência de uma fase de trabalho experimental por parte do contista.

O conto apresenta vários arcaísmos, tais como: "atroada", "trabalhadeiras", "aprouvesse", “folgazão", "soalho", "rentinhos", entre outros.

Considerando a violência que, neste conto, se constitui em tema, aproximamo-nos mais uma vez de Maria Sylvia de Carvalho Franco que discorre a respeito das modalidades de violência no ambiente rural $^{71}$. Em função da ocorrência de muitas formas de violência naquele meio, fez-se necessário subdividir o tema segundo o espaço e o momento, solução com a qual concordou Antonio Candido em Os parceiros do rio Bonito ${ }^{72}$.

Ainda a respeito da violência, Carmen Lydia de Souza Dias ${ }^{73}$ considera que é necessário pesquisar sua incidência nas circunstâncias de "vizinhança", "trabalho", "lazer", "parentesco" e "pobreza", seguindo o esquema delineado pela socióloga Maria Isaura Pereira de Queiroz ${ }^{74}$, cujos estudos mostraram a profunda ligação da atitude violenta com o dia-a-dia sertanejo.

Com base no desfecho trágico do conto, podemos vislumbrar, em certa medida, um aspecto da visão de Brasil que Valdomiro Silveira possuía: a de um país, em seu ambiente rural, marcado pelo código da violência, que era produzido por valores morais muito arraigados, oriundos de padrões morais arcaicos.

\footnotetext{
${ }^{70}$ DIAS, Carmen Lydia de Souza. Op. cit., p. 196.

${ }^{71}$ FRANCO, Maria Sylvia de Carvalho. Op. cit., p. 20-47.

${ }^{72}$ CANDIDO, Antonio. Os parceiros do Rio Bonito. $2^{\mathrm{a}}$ ed. São Paulo: Duas Cidades, 1971.

${ }^{73}$ DIAS, Carmen Lydia de Souza. Op. cit., p. 62.

${ }^{74}$ QUEIROZ, Maria Isaura Pereira de. Bairros rurais paulistas. São Paulo: Duas Cidades, 1973.
} 


\section{$\underline{\text { Castigo do céu }}^{75} 36$}

\section{$\underline{\text { Ao Alarico Silveira }}$}

- Mas por que foi que você me ficou querendo tanto bem?

- A falar um pouco de verdade, nem sei: mas cuido que foi porque descobri nos seus olhos a lealdade do seu coração. Você não se lembra que logo logo que tomei conhecimento com você, já contei pra muita gente que 'tava apaixonado?

- Lembro muito, demais: até isso aconteceu numa festa do espírito santo que houve em santa cruz; por sinal que você vinha montado num cavalo oveiro, muito feio, que pegou de corcovos assim que os foguetes começaram a chiar.

- É isso mesmo, tal e qual. Você ia saindo da igreja co'a sua mãe, e vestida de chita de ramos cor de rosa, pois não ia?

Ao lusco-fusco da boca da noite, debaixo dum çoita-cavalo de ramadas enormes, conversavam deste modo, sem tirar nem pôr, o Totico e a Rosinha. A voz dos dois era macia e de segredo quase; tanto, que um casal de chanchãs que cutucava o tronco da árvore, nem deu fé, sequer, de que em baixo havia duas pessoas: e não há quem não saiba que os chanchãs são pássaros muito velhacos e mexeriqueiros.

O Totico, afamado pela sua mão de rédea para acertar, ganhara fama também, na Mandaçaia e redondezas, de bicho carpinteiro da alminha das moças. Ele próprio afirmava, a quem quisesse aturar-lhe as gabolices, que, para mula chucra, basta passar a mão no fio do lombo e montar; que tal mula talvez dê seus saltos, um pulo ou outro, mas logo sossega e pode levar-se pela sombra, que já não conta mais histórias: e que a diferença dûa mula chucra para ûa mulher, não é lá tão grande coisa!

Depois de variadas aventuras, encontrou no caminho de suas reinações a Rosinha, a criatura mais carinhosa que Deus pôs neste mundo, e resolveu enfeitiçá-la. A pobre, que morava lá por aqueles fundos da cachoeirinha da boa vista e não maliciava de ninguém, vendo-o tão cheio de bondade e falando palavras tão doces como as que ele sabia, ficou logo entregue. E as coisas foram-se encaminhando de tal jeito, que um dia, quando ela quis precatar-se contra as tentações daquele demônio, já era tarde. Diz que cada um de nós tem seu anjo da guarda, que ensina a estrada certa da vida e livra dos precipícios: o da Rosinha na

\footnotetext{
${ }^{75}$ Nota CLSD: “O Estado de S. Paulo. São Paulo, 18 jan., 1903. (Escrito em Sta Cruz do Rio Pardo)".

${ }^{36}$ Nota da edição: Manuscrito presente nas pastas Mucufos e Originaes manuscriptos de Papae (preciosíssimos).
} 
certeza cansou por então, e dormiu, deixando-a bem acordada, e o inimigo do inferno, aproveitando-se da ocasião, tomou conta daquela criatura desprevenida. Sem dúvida é assim que todas as outras erram o caminho e se perdem: um descuido, um sozinho qualquer do anjo da guarda...

Notícia má corre que é um despropósito. Em poucos dias o povo da Mandaçaia foi sabedor daqueles amores. Mulheres idosas aconselhavam à Rosinha que tivesse tento consigo, porque o Totico era uma alma perdida: e mal sabiam que esses conselhos já chegavam tarde e a más horas. Ela, então, que tiritava de susto ao pensar no futuro, principiou a ficar melancólica e distraída. No meio da melancolia e da distração em que se abismava, constantemente a viam tremer e agitar-se que nem varas verdes: e, se lhe perguntavam porque tremia assim, respondia que eram nervos. A resposta contentava, e ela ia vivendo: e, nem bem o sol entrava, já seu vulto aparecia, à espera do Totico, no lugar marcado de véspera.

Tantos medos lhe pregaram, que entrou a cismar que o Totico podia desampará-la ao Deus-dará, de uma hora para outra. E como não tinha arte nem uma para dissimular os pensamentos que a possuíam, um dia que o Totico desejou saber a razão de ela estar magoada, logo lhe foi dizendo que se atemorizara por certas prosas que ouvira: e todas lhe repetiu.

O Totico faltou só bater-lhe: ficou irado, com os olhos em ponto de fogo e a boca tremendo: chegou a dizer-lhe que, se não o acreditava, tratasse de se esquecer dele, que ele faria o mesmo e jurava e trejurava que tudo aquilo era mentira. Quem vive namorado não põe muita relutância em crer o que a pessoa predileta diz: a Rosinha, apesar de lhe fazer espécie o semblante enfurecido do rapaz, já estava meio cá, meio lá, para se convencer. O que não conseguiram as palavras, um simples agradinho o conseguiu, porque o Totico pô-se a abraçála, a Rosinha enterneceu-se, e a discussão não foi por diante: por estas e outras é que ele assegurava que a diferença de ûa mula chucra para ûa mulher não é lá tão grande coisa...

Ora mais dia, menos dia, a Rosinha deu de ficar moleirona e mofina. A princípio sentia umas pontadas de banda, que muito a atormentavam; depois perdeu a fome de uma vez, chegava à mesa e nem bulia nos pratos; olheiras cor de violeta cercaram-lhe os olhos; perdeu a coragem para todo e qualquer serviço; doíam-lhe as cadeiras. A mãe, que vivia na inocência, balanceava entre preparar algûa mezinha ou mandar fazer-lhe qualquer benzedura: pensou, pensou bastante, e resolveu chamar para consulta uma curiosa de muito bom renome, a Joaquina das Pedreiras. 
A Joaquina das Pedreiras, tanto que soube da doença, já sentiu a pulga atrás da orelha. Veio, apalpou a Rosinha, deu-lhe palmadas leves no ventre, passou-lhe a mão no pescoço, e declarou, alto e bom som, que aquilo era moléstia de nove meses. A mãe da Rosinha pulou-lhe à goela, chamando-lhe os piores nomes deste mundo: ordinária, desgraçada, caveira do demônio, e outros de maior porte, ao fim dos quais, e sob garras tão frenéticas, a mezinheira começou a soluçar. Abrandou-se o coração da mãe da Rosinha, e a Joaquina das Pedreiras logrou sair, praguejando e com o pescoço a correr sangue. E daí a pouco se verificou que falara verdade...

O Totico fugiu às léguas, mal que soube do acontecido. Bem diziam que ele era uma alma perdida, bem diziam! Ninguém lhe botou mais os olhos em cima: tornou-se num repente sumidiço que nem bicho do mato. Apenas, de vez em quando, aparecia notícia que o tinham visto para os lados do capivara, como capataz de porcada dum tal Maneco de Lellis: até que enfim o silêncio caiu sobre o nome, e quem continuou a ser lembrada e a padecer foi a Rosinha.

E que padecimentos! As mães de família tratavam-na de resto, olhando-a sempre com ares de pouco caso; as antigas companheiras evitavam-na sempre; aonde ela ia como que tudo se desolava na mesma hora; os próprios homens erados a entristeciam, passando-lhe pitos e dizendo indiretas que a pungiam como os espinhos da macaúba ${ }^{37}$ com que a gente esbarra à sombra duma touceira, no emaranhado. Achava tão extraordinário o que lhe sucedia, que nem dava tino das desfeitas e como que ficara meio idiota: após tanto choro e prantear, nada mais lhe restava que pedir a Deus lhe perdoasse e a recebesse na santa glória: e não tinha ânimo de dirigir tais súplicas a aquele de quem se desviara pelo pecado.

Chegou o dia de adoecer. Foi no senhor menino. Meio mundo se preparava para ir à missa do galo, quando ela principiou a sentir as dores. Chorava que era uma lástima, queixava-se da sorte e amaldiçoava o momento em que conhecera o Totico; mas apesar de tudo não o amaldiçoava, a ele que lhe dera tais e tantos sofrimentos, deixando-a sozinha com a mágoa e com o desespero. A mãe, que de perto lhe ouvia os gemidos, tinha os olhos amarados de lágrimas: e dava dó ver aquelas duas sofredoras assim.

\footnotetext{
${ }^{37}$ Nota da edição: Segundo FERREIRA, Aurélio Buarque de Holanda. Op. cit., p. 1058, macaúba, palavra que no tupi é ma'ká ï'ba, 'árvore da macaba', se constitui em um brasileirismo que é o mesmo que coco-de-catarro (op. cit., p. 424) que, de N. a L. do Brasil, quer dizer "espique ornamental, da família das palmáceas (Acrocomia sclerocarpa), de fruto drupáceo, comestível, amarelo-pálido, de aroma agradável, flores monóicas, suavemente aromáticas e amareladas; coco-baboso, coco-de-espinho, coco-macaúba, macajuba, macaibeira, macaúba, macajá, macaíba, mucajá, mocajá, bocaiúva. [Pl.: cocos-de-catarro.]”.
} 
Quando nasceu a criança, um menino miúdo e sadio, a Rosinha desmaiou na loucura da febre; os olhos pareciam-lhe brasas ardentes, e de brasas ardentes se lhe afigurava estarem circuladas as fontes; o secume dos lábios era-lhe insuportável; o ofegar do peito doía-lhe: e como um espectro que a perseguisse, a todo instante, vagava-lhe em torno o Totico, sem dizer nada, com a expressão de semblante de um gira. Várias vezes ela disse, na tormenta do delírio:

- Nhá mãe, nhá mãe, tire o Totico daqui, porque ele 'tá louco.

E a mãe, silenciosamente, rezava, rogando aos poderes do céu que afastassem da infeliz, ao menos agora, aquele satanás que só lhe trazia torturas. Pouco a pouco, porém, serenou o desafortunado espírito da moça: ela dormiu, num sossego semelhante ao da morte, pois mal se lhe escutava a respiração -, e a mãe, aos pés da cama, ficou velando-lhe o sono até as horas mais claras da madrugada.

Ao acordar, sobre tarde, a Rosinha pediu o filho. Contemplou-o largo tempo: e uma enxurrada quente de lágrimas deslisou por suas olheiras abaixo, até cair às faces e à boca da criança, que lhe estranhou o amargor. A Rosinha então falou-lhe, como se a criança pudesse entendê-la:

- Meu choro é muito amargo, filhinho? Veja só quanto aquele home' de coiração de pedra não me tem feito sofrer! Mas tomara que nada lhe aconteça, porque pode que inda sirva de muito pra você, pra você que é tão desprotegido, meu filhinho!

Foi um inferno, a vida que a Rosinha levou, até que o menino engatinhasse. Vigiá-lo a toda hora, quando o serviço caseiro queria cuidados contínuos, quando era preciso contar a criação, aprontar as rações do curral e do chiqueiro, fazer o almoço e a janta, remendar as roupas velhas, são coisas que só não pesam a quem traz o coração lavado e alegre. Fraca se sentia, a coitada, assim que se deitava para conciliar o sono: e esse mesmo era interrompido sempre pelo chorar noturno.

Pesadelos e maus sonhos apenas esperavam que ela cerrasse os olhos, para angustiá-la: e sucediam-se um após do outro, noite fora, como uma singular penitência. De modo que os olhos se lhe afundavam, as faces iam-lhe tomando a cor das velas de cera e a voz se lhe fazia abafada e baça.

Afez-se a madrugar demais. Nem bem a manhã principiava a arraiar, levantava-se; muitas vezes, ao depois de assear a criança, chegava ao pátio, sentava-se a um banco de peroba, e punha-se a contemplar o filho, com uma tristeza que era também enternecimento e apreensão: vendo bater os primeiros raios de sol naquele rosto mimoso, assustava-se, ideando 
que um fio de sangue lhe corria pela epiderme, provindo dalguma grande ferida: erguia-se então de pronto, caminhava para a faina.

Mandava nûa máquina de costura como ninguém; para botar uns pespontos, estava de banda; lidava muito bem na feitura das rendas: e como atravessava quase o dia inteiro junto à máquina, foi um dia remexer moldes antigos para fazer certo vestido. No meio dos panos e papéis havia de tudo: dedais, agulhas de mão de todas as grossuras, linhas de todo número, retalhos de chita, alfinetes. A brilhar e rebrilhar entre aquela trapizonga, apareciam vidrilhos ao lado de carrretéis, contas de pérola espalhadas a parzinho de contas de celulóide. Através da barafunda, movida e removida, tremeu alguma coisa que dava ares de nada valer: uma rosa seca. Pois foi de admirar o estremecimento que a moça teve, ao tocar na triste flor, e ao vê-la murcha assim: era de jurar que a pobre moça imaginava que a pobre rosa, amiga sua, padecia o mesmo desespero que ela!

Rosa que tudo dizia! Uma vez, depois de olhares amorosíssimos trocados de esconso, na igreja, nos pagodes, ao longo das estradas da Mandaçaia, a Rosinha encontrou-se com o Totico por debaixo dum çoita-cavalo, no pasto, e prosearam muito tempo... Foi dessa vez que ela se sentiu entregue e sem defesa, e foi aí que recebeu aquela flor, que passara a suas mãos de uns dedos trêmulos e como febris. Desde então não soubera nunca mais o que é descanso de coração: e sentia-o agora avelhentado e sem esperanças, tal e qual aquela mesma flor, que era impossível revivesse e corasse ainda.

Inclinou-se para a gavetinha onde se amontoavam os guardados; repousou o queixo na mão direita; os pensamentos, cruzando-se-lhe no espírito à semelhança de um bando de passarinhos estonteados, voaram, voaram: e enquanto eles partiam - talvez ficasse saudosa por vê-los partir, talvez medrosa de que voltassem -, de novo o ribeirão das lágrimas correu por aquele rosto meigo, em dois galhos, sobre os leitos escuros das olheiras.

Já transmontara o sol, quando surgiu da abstração em que se embrenhara. Acumulavamse nuvens extravagantes, ao longe, como se houvessem nascido do seio das montanhas e agora crescessem apavorantemente na meiga luz tristonha do crepúsculo. Os urutaus gritavam de pedaço a pedaço, os xintãs davam os derradeiros pios. $\mathrm{O}$ ar estava carregado de um cheiro forte de cambarás-de-lixa. Os sabiás-unas cantavam cantigas apaixonadas.

Rosinha pôs-se em pé, serena que nem um fantasma: e por virem os últimos raios do sol avermelhar a janela a que se recostara, seu rosto ainda inculcou mais sofrimentos, dentre o fogo triunfal que a circundava. 
Mais tempo, menos tempo, ia passando pela estrada o Totico, algum tanto arrependido da feia ação que praticara. Vinha montado num tobiano uçu, bracejador e engraçado como poucos: e como a estrada tinha muito estrepe, o tobiano dava muitas topadas: e como a alma do Totico se achava deveras apreensiva, cada abalo do animal the era um abalo no fundo da alma.

Ao chegar em frente à porteira do pátio, conheceu a Rosinha; conheceu-a, e ficou duro no socado, tal e qual como se tivesse tido um acidente, porque a viu magrinha e pálida a causar pena: e sentiu forte pena, realmente, acompanhada às surdas de um remorso muito agudo, que ele ainda se não confessava, mas que o deixava todo amargurado.

Quis voltar por algum desvio, mas já não pôde, que a mão não teve forças para torcer a rédea: e permaneceu larga temporada a vizinhar com a porteira, tendo os cabelos em pé e o corpo frio. Não lhe vinha uma idéia salvadora. Botaria o tobiano a galope? Faltava-lhe coragem. Abriria a porteira? Não tinha modos de falar à Rosinha, à pobre a quem perdera, e de cuja existência negra tivera notícias lá pelo capivara. Ela, porém, saiu ao pátio: e o poente desmaiava a pouco e pouco, no momento em que deu a mão ao Totico para ajudá-lo a apear. A voz paralisava-se-lhes na garganta; o grito longínquo dos urutaus infundia um pavor indizível à quietez da natureza sonolenta: - e podia-se pensar, olhando-os, que o que sobremodo lhes tolhia a voz e os magoava tanto era o lamento sugestivo dos urutaus.

O Totico, de repente, montou de novo. Impulsava-o um sentimento desconhecido, talvez o medo de si mesmo, da sua consciência pecadora e baixa. Cravou firme as chilenas nas ancas do cavalo.

E enquanto Rosinha lhe perguntava:

- Pois você nem ao menos quer ver o filhinho, desnaturado? - a imagem do pampa sumia na poeira do caminho, clareada do luar nascente. O Totico soluçava; seus soluços, levados pelo vento, confundiam-se com os dos curiangos: e não se sabia bem quais eram os mais doloridos.

Ninguém o esperava em casa, e foi uma festa o verem-no chegar assim de surpresa. Cercaram-no todos os seus, a abraçá-lo; mas, reparando-lhe nas esquisitas feições do rosto, assustaram-se e murcharam como por encanto. Cada qual queria saber a razão de tamanho banzo: e as confidências apareceram na conversa, recatadas e segredosas. Explicava o Totico a cena acontecida, e seu falar parecia nublar-se de um nevoeiro de incertezas: pois dizia, o 
infeliz, que outras mulheres também tinham choramingado um eito, mas afinal todas se consolaram e aí andavam pintando a moringuinha pelo mundo de Deus .

Todos se arrepiaram, recordando-se da Rosinha: que essa, qualquer podia jurá-lo em cima duns evangelhos, não procedera por tal forma.

E, para realçar a constância da roceira da Mandaçaia, não faltou quem narrasse os delírios que ela teve, e as frases que dissera através dos delírios. Foi repetida a história de que ela falara à mãe, uma vez, lhe tirasse de perto o Totico, porque ele estava fora do juízo.

Mal que lhe soaram as últimas palavras da narrativa, o Totico estremeceu como um broto de assa-peixe à ventania; enveredou por um cogitar complicado e cheio de labirintos, do qual só rompeu muito tarde depois, quando os galos já estavam amiudando.

Abriu a porta que dava para a estrada, e olhou a noite de lua.

Viam-se bem as sinuosidades das serras e os recortes fantásticos dos caminhos, por onde, a quando e quando, avoaçavam os purrutuns, numa perseguição lasciva que falhava com a sumidura das companheiras para o outro lado da aguada. $\mathrm{O}$ acertador sentia-se perturbado: se aquilo saísse certo? Se ele ficasse doido, agora?

Aturdia-lhe as fontes e ouvidos em extraordinário fragor; ficaram-lhe as pernas bambas, sem resistência, a badalejar uma contra outra; o coração galopava-lhe desesperado na caixa do peito; o olhar enchia-se-lhe de avassaladora umidade... Tornou-se necessário que o chamassem, para afastar-lhe do espírito aquela obsessão; deitou-se, dormiu um sono entrecortado de pisadeiras e súbitos despertares, ao fim do qual viu-se fatigado como depois de um serão trabalhoso. E a lembrança do delírio da Rosinha voltava-lhe à mente, a todo instante, com uma insistência vivíssima.

Perguntaram-lhe, à hora do almoço, porque não casava duma vez com a Rosinha, que era tão boa, e lhe queria tanto, e lhe fora tão fiel, e por ele topara tanto padecimento na vida? Era o desejo que ele tinha agora, mas faltava-lhe ânimo para mandar um recado àquela desditosa. Ir, bem podia ir sozinho, para ninguém presenciar a choradeira lastimosa que havia de haver: ela por um lado, ele por outro. Mas, pensava, ao mesmo tempo, que seria até capaz de ficar sufocado e não poder dizer coisíssima nem uma, por amor da comoção. E só a idéia do quanto se lhe iria aumentar o remorso, ao pé da Rosinha, atenuava-lhe sobremaneira a força da resolução. Por último, quase que se resolvia a ir em pessoa procurá-la. 
Pensava no meio de se dirigir à malfadada criatura, quando viu em torno de si rodopiar tudo à semelhança de milhares de piões; vergaram-lhe os joelhos; as mãos tactearam-lhe, em desvario, o arredor: e caiu com os olhos em alvo e a boca espumante, num ataque convulsivo.

Escabujava como um possesso, arqueando e distendendo o corpo, tornando a arqueá-lo e distendendo-o logo em seguida; agitavam-se-lhe, num frenesi tremendo, os cantos da boca, donde a par da espuma, rompiam estrias de sangue arrancado, com a fúria nervosa, dos rebordos da língua; os braços, que durante momentos apenas tinham acompanhado ao de leve os movimentos de todo o corpo, barafustavam desesperadamente, dando cotoveladas e punhadas terríveis pelos móveis.

Depois, com gradações de mais em mais espaçadas, foi sossegando; o arquejar acelerado do peito diminuiu, ao passo que o corpo se inteiriçava em decúbito dorsal; as mãos caíram-lhe sobre o ventre, enclavinhadas já sem crispações; os olhos deixaram de tremer, tomando ares de olhos de idiota; quietou a boca: - e um suspiro prolongado deslisou pelos lábios cheios de espuma e de sangue.

De roda dele diziam que aquilo era um ataque de gota, feito os que o pai também tivera em vida, tal e qual: decerto pelo exagero da viagem. As vozes eram cochichadas com resguardo, sucediam-se os gestos e os sinais. E a mãe do Totico, aloucada de pavor, fizera-se branca que nem um bugarim, dizendo que aquilo não passava de castigo do céu. Foi então que apareceu a Rosinha, chamada às carreiras: aproximou-se do Totico, pôs-lhe a mão na testa suarenta, e, como ele fitasse nela um olhar assustado e longo, falou-lhe:

- O que é isso, Totico? Aqui 'tou eu, a Rosinha, que te perdôo e te quero bem como toda a vida!

Ele custou a erguer-se, mas ergueu-se. Pôs-se de joelhos, ali no chão mesmo, em frente à Rosinha, com os membros ainda mordidos de tremuras repentinas, quase calafrios. E enquanto ela se abaixava para abraçá-lo, febricitante e chorosa, o filhinho começou a brincar com os cabelos de ambos, rindo perdidamente. 


\section{$\underline{\text { Análise do conto }}$}

O tema desta narrativa é o amor entre um homem e uma mulher. Caracteriza-se principalmente pela narração em terceira pessoa e poucos diálogos. É experimental no sentido de ser, talvez, um repositório do caso para uma reelaboração futura por parte de Valdomiro. Segundo Carmen Lydia de Souza Dias, "Castigo do céu” é um conto estilisticamente imaturo, embora mostre, no desenrolar dos motivos (tais como doenças, festas religiosas, medicina caseira, namoro, trabalho genérico e trabalho doméstico), a mesma perspicácia e envolvimento com a natureza, demonstrados em "Na tapera de nhô Tido", presente em Os caboclos. O conto é imaturo no sentido de que nele ainda não foram dosados os regionalismos, o falar caipira não foi adequado ao "causo", cujo conteúdo dele necessitava para se totalizar como experiência humano-regional, esteticamente válida. Isto ocorre, segundo Carmen Lydia, "porque o autor não inventou o caso para usar o dialeto"38.

Para o crítico literário Péricles Eugênio da Silva Ramos, Valdomiro Silveira "socorre-se do dialeto" para divulgar o caso, por ele já arquivado na memória e na observação ${ }^{39}$, posição essa compartilhada por Carmen Lydia de Souza Dias.

Em "Castigo do céu" ocorre a mescla de linguagens (que ora aproxima o narrador-autor culto, ora o distancia do objeto de sua representação literária, o caipira): o coloquial culto com o falar caipira. Um bom exemplo disso é a seguinte passagem:

"O Totico, afamado pela sua mão de rédea para acertar, ganhara fama também, na Mandaçaia e redondezas, de bicho carpinteiro da alminha das moças. Ele próprio afirmava, a quem quisesse aturar-lhe as gabolices, que, para mula chucra, basta passar a mão no fio do lombo e montar; que tal mula talvez dê seus saltos, um pulo ou outro, mas logo sossega e pode levar-se pela sombra, que já não conta mais histórias: e que a diferença dûa mula chucra para ûa mulher, não é lá tão grande coisa!"

No trecho acima, podemos observar algumas palavras eruditas, tais como "afamado", "ganhara" e "gabolices", convivendo bem com expressões tipicamente regionalistas e

\footnotetext{
38 Op. cit., p. 195.

39 RAMOS, Péricles Eugênio da Silva. "Valdomiro Silveira e as origens do regionalismo sertanejo em nossa ficção”. In: SILVEIRA, Valdomiro. Nas serras e nas furnas. Rio de Janeiro: Civilização Brasileira; Brasília, INL, 1975. p. XXXIII.
} 
populares, tais como "mão de rédea", "bicho carpinteiro", "mula chucra". Encontramos, também, alguns arcaísmos (principalmente de forma), tais como "dûa", "ûa" e "algûa". 


\section{$\underline{\text { Seo doutor }}{ }^{40}$}

A papai,

de todo o coração.

Quando na fazenda se soube que Valdóro ia aos estudos, não houve quem não fechasse muxoxo e não levantasse ombreira, porque ninguém quis acreditar: um tal dizia que menino assim, que até os catorze anos não tomou tenência e é reinador e mexerendengo, foge das coisas sérias da vida, como o demo da cruz; outro afirmava que já havia visto resoluções semelhantes, as quais em breve tempo se desfizeram, como as borbulhas d'água que a capivara faz no açude, ao escapar de uma perseguição; outro, enfim, malvado a mais não poder ser, afiançou que o filho da patroa não deixaria a santa terra, por andar de velho derriço com a Isa, filha de nhá Marcolina.

Por este teor e forma, foram levando a conversa os diabos dos caboclos. Deu-lhes a notícia o Baltazar, o mais arteiro sujeito que o céu cobre, e criticou-a a seu bel-prazer: e desde que ele puxara a fieira, os demais agarraram direito no diz-que-diz-que. Entrecontaram-se façanhas de arrepiar os cabelos: o andar Valdóro pelos grotões, a campear ninhos de urus, o armar-se de bodoque para martirizar os guaxes no laranjal, o judiar dos poldros e o perseguir os piriás pelos brejos. Tudo lhes veio à retentiva, aumentado por ûa memória que sofria os calores da imaginação: que o menino, em resumo, não era tão ruim peça como eles queriam, lá isso não era, decerto...

O Baltazar, que os encontrara no terreiro da casa da máquina, disse também cobras e lagartos à conta do patrãozinho: e a maledicência, então, por momentos, ocupou quase todas as bocas do grupo. O Marcolino saiu-se com esta:

- Vocês têm reparado nos meus garnizés? São muito lindos, mas mesmo muito... Pois não é que Valdóro às vezes cai na maluquice de vir atirar pelotas no galinheiro e os aniquila sem dó nem piedade? Aquilo é um precipício!

Depois teve a mão o Demétrio:

- Você ainda não sofreu nada. Que diria se lhe acontecesse o que me aconteceu! Não faz tempo grande, eu estava transplantando umas couves na horta, sossegado, sossegado, e

\footnotetext{
${ }^{40}$ Nota CLSD: “A Bruxa. Rio de janeiro, 9 e 16 out., 1896. (Escrito em Sta. Cruz do Rio Pardo)”.
} 
recebo na cabeça uma pancada terrível. Sabe o que tinha sido? Um terrão duro que o bruto me apinchou.

Em seguida fez-se ouvir o Teófilo:

- Isso prova que ele é deveras endemoninhado, não há dúvida, e portanto não terá jeito para a vida das leituras. Mas, se não creio que ele se vá embora, é por diverso motivo: um dia destes - olhem que até foi domingo derradeiro - vi resvalar dois vultos no jardim, que andavam no seguimento de uma rolinha chumbeada. Por fim pegaram a rolinha e muitos beijos lhe correram pelas penas: mas a maior parte dos beijos sobejava do pássaro e ia de um vulto ao companheiro. Não preciso botar mais nada na carta: a Isa e o Valdóro contarão o resto...

- Ora que dois! - admirou-se o Martinho.

- Há cada história! - o Teófilo rosnou, com semblante enigmático.

- Venha daí mais uma! - pediu o Demétrio.

Mas o Teófilo conteve-se: os parceiros bem sabiam que ele não gostava de tesourar a humanidade. Se narrara aquele fato, aliás com serenidade o fizera, porque não via mal no simples passeio que duas crianças dão pelo jardim. E, atenuando o acre da narração, mais ainda, concluiu:

- Rapazinho de entendimento está ali! Vocês hão de ver, se ele for mesmo! Sou muito gente para apostar este meu dedo em como o dando faz carreira. Vocês hão de ver!

Os outros, contudo, continuavam a fechar muxoxos, murchos duma vez, e alevantar ombreiras significativas de funda incredulidade. E nem bem o Teófilo de por findo o seu discurso, já o mundico levou por diante a forte teima:

- Ele, voltar doutor em leis? Capaz! Com estes meus olhos que aterra há de comer, tenho visto tanta coisa feia praticada pelo tal maganão, que não posso receber esta notícia com bastante fé. Pois então, um tipo que é amigo de atacar as chilenas aí nesses infelizes cabritos, passar o pialo nos novilhos, prender os alcaides com varas de visgo e os jaós com urupucas, terá coragem de queimar as pestanas em riba dos livros? Capaz!...

$\mathrm{Na}$ verdade, não havia quem assim não pensasse. Houve, porém, no meio daqueles caboclos, alguns que se quedaram à escuta, sem nada aventurar que aumentasse os rigores da crítica. Esses, se porventura fossem novidadeiros, dariam à trela no sentido de contar que o rapazinho chegara ao ponto, numa passada noite, de ir cantar trovas de amor inflamado sob a 
janela da Isa: e a galante menina, apesar da alta hora, havia assomado à janela e deixando cair sobre a cabeça do cantor um punhado de pétalas de flores...

Duvidaram sem razão, supondo impossível a partida. Pois o dia que se marcara para a mesma alvoreceu enfim, vindo encontrar prontos os preparativos da viagem. Valdóro, logo que lhe entreluziu a manhã pelo teto de palhinha, acordou e soltou da cama, num movimento resoluto; e, enquanto banhava o rosto, às pressas, a Felipa monologava na cozinha, arrumando o café. Pombos arrulhavam no telhado, passeando por certo à roda das pombas, e as asas, que se lhes estendiam todas em sinal de cortesia, começavam de rugir com insistência entre os oitões e as telhas.

Da banda de fora do terreiro, o Pedrinho da Faxina gritou:

- Seo Valdóro, alevante-se, que as juntas já estão nas cangas e tudo se acha preparado: a da guia pintou a manta, mas concordou comigo, e aqui está de olhos virados pro chão.

- Sempre essa junta da guia foi teimosa e contadeira de história, - disse Valdóro, e mudou logo de tom - : ó, Pedrinho, você quererá tanto bem aos meus carneiros como eu lhes quero e tomará conta deles como se fosse eu mesmo?

- Sossegue que assim será!

Valdóro saiu. Ao pôr o pé na taboa de junto à porta, a taboa deu de si em toda a extensão, e gemeu como um escoroçadouro ou como uma pessoa atormentada de dores ocultas: e o menino, que por sinal nem vinha pensando em coisas magoadas, perguntou entre si se aquilo não seria na realidade uma lástima pela sua negra sorte. Pulou os degraus da escadinha, chegou ao terreiro, tomou uma das varas e começou a tanger os carneiros dasanimados. O sol já estava de fora. Contemplando-o, de olhos tristes e semblante brusco, Valdóro como já sentia no coração as primeiras lançadas da saudade: o que lhe amargurava era um sentir nunca sentido, uma apertura esquisita que mal se podia explicar; parecia que uma corda lhe arrochava metade do coração, ficando a outra metade vazia e com friura de geada.

A neblina da manhã não se afastava ainda de sobre os morros: apenas, de longe a longe, quenturas de sol a mordiam, dourando-a; e a estrada, que o arrebol abria naquele flanco, era estreita e pequenina. Valdóro, atentando nas brumas, falou, como se fosse num solilóquio: 
- As minhas aspirações também são assim, alvas, mas indecisas... Tempo chegará em que o sol as ilumine esplendidamente: as brumas ir-se-ão dissolvendo, e acima delas aparecerá o céu, encantado de azul.

O Pedrinho encarou nele, perdendo a cocha: viu-se em branco, sem dúvida, ao escutar dizeres como os do Valdóro, que se inventaram para cabeças de entendimento, e não para a de um rude candieiro de carro, cuja lavra principiava ao amiudar dos galos e terminava ao empoleirar das galinhas. Pelo menos, ia o pobre candieiro maturando desta sorte, amesquinhando-se dentro de si mesmo, fazendo-se pequenino em razão do nhonhô patrãozinho já se ir fazendo grandes: amigos deste volume poucos se encontram, por certo, neste mundo, em que cada qual, ao crescer quer que os demais se lhe desmereçam e atrofiem à sombra...

O carro, entretanto, movia-se com vagar pela estrada que o sereno da noite molhara: com vagar, que conduzia uma alma desafortunada, e almas, que tal modo se vêm, parecem até arroubar-se na própria amargura e demoram-se a contemplar o quadro negro que os pensamentos lhe estão a traçar lá dentro. A intercadências, uma ramada úmida vascolejava-se ao toque os fueiros: e os dois piás, que iam sentados na mesa, recebiam nas faces o orvalho frio, - tão absortos que nem se furtavam às vergastadas de todo minuto. $\mathrm{E}$ as rodas, dando de encontro aos barrancos, soltavam gemidos fracos.

As despedidas (aquilo não passava de uma viagemzinha de despedida) começaram pelo Demétrio, que assistia mesmo ao fim do pomar. Embora fosse tão cedinho, já ele estava á porta da palhoça, arredando um cavalo pedrez. Ia botar a carona, quando Valdóro o chamou:

- Ó seu Demétrio?

- Bom dia, patrãozinho; que ventos o trazem? - perguntou ele.

- Venho receber as suas ordens: lá me vou.

- Resolve-se então duma vez?

- Duma vez.

- E não acho que pode não se acostumar?

- Não acho. Pelo contrário.

- Pois eu desejo que nhonhô seja muito feliz.

- Deus lhe pague. E se nalguma ocasião o ofendi, desculpe, que me arrependo.

- Ah! Isso nunca! Vosmecê é que há de prender alguma falta.

- Adeus, Demétrio. 
- Adeus, seu Valdóro. Volte logo, ouviu? Mas nem tomou uma canequinha de café com a gente...

- Obrigado, obrigado: não tenho tempo. Adeus!

- Bons ventos o levem e melhores o tragam!

Quem é que seria capaz de calcular que Demétrio ia ficar de olhos aguados, que é? Pois ele, que tinha tantas queixas contra o rapazinho, sentia assim a partida? Sentia, sentia, porque uma coisa é falar e outra é pensar: e mau grado a trampolinagem do Valdóro, o Demétrio tinha-o em alta estima, vendo-o crescer ali na fazenda, alegre e sem luxo com os pobres. Fora ele até que ensinara ao menino a moda do marimbondinho a uma porção de castigas e tiranas: chegara a esse ponto de paciência.

Um por um, todos os agregados tiveram a visita. Os carneiros, ao chegarem junto às portas, já respiravam a custo e com afrontação. Mas era preciso que ninguém lhe esquecesse, e Valdóro procurava todos. Quem mais dissera mal, mais se entristecia com a retirada: e causava dó ver como ficavam murchos os crilinhas e as pequenas caboclas do tempo de esconde-esconde e do que-pau-é-este. O Teófilo, o Mundico, o Baltazar, o Martinho e os outros roceiros auguravam-lhe venturas no colégio, como diziam. O Lico da Benvinda (um dos que haviam ficado quietos, quando os demais batiam caixa no nome do Valdóro), assim que o viu, veio logo limpando as lágrimas: e abraçou-o tanto, com tanta amizade, com tanta tristeza, que o corpo do amigo pegou a doer.

A derradeira pessoa visitada foi Isa. Mas para essa não se tornou necessário que os carneiros parassem à porta da casa. Enquanto, só, o Pedrinho dirigia o carro, Valdóro foi esperá-la à beira do ribeirão, no mesmo lugar em que outrora havia armado um mundéu. $\mathrm{O}$ sol já estava de queimar. As borboletas e lavandeiras sentavam perto da água, movendo as asas com uma vagareza que era cheia de preguiça. E o folhudo ingá da margem, debruçando a ramaria por sobre o tronco, tinha ao fundo do leito uma imagem quase misteriosa, de tão sombria. Mal que viu o vulto do namorado, a Isa disparou a chorar: o se Valdóro não começasse a beijá-la, jurando-lhe mil coisas, não era difícil que a afligida criatura chorasse choro de sangue. Isso mesmo ela falava, no entretempo das carícias: e com forte convicção, que o companheiro deu de olhá-la a fito, afim de ver se daqueles amados olhos poderiam brotar mágoas vermelhas. Despediram-se enfim! Ele saiu de sopetão, suando frio e com um nó na garganta, que lh'a apertava tenazmente: e ela, desvairada pelo pesar, nada mais pôde 
fazer que cair meio sem sentidos junto à raiz do ingazeiro. Os capixingüis e cambarás-de-lixa permaneciam imóveis, como se a imensa dor da pobre os tivesse comovido.

À hora em que a comitiva saiu, numerosa e barulhenta, a mãe de Valdóro encostou-se à janela da varanda: ficou a olhar a poeira que a cavalgada levantava ao ar, quando já não podia ver filho muito querido; através do sofrer que a pungia, brilhava a esperança no futuro, e ela como que se via mais refrigerada, ao antever a volta daquele estremecido caboclinho feito doutor. O pai de Valdóro acompanhava a espaços os cantos da boca. Mas os sentimentos dos pais são coisas que não se descrevem...

Dobraram-se seis anos.

Alvoreceu um dia, como todos os dias alvorecem, vermelho para as bandas do nascente, cor de ouro para as bandas do ocaso, o qual dia já encontrou meio mundo acordado na fazenda. Havia um reboliço em cada canto a azáfama pela casa inteira. A mãe de Valdóro, diligente e risonha, andava dando ordens na cozinha, na varanda, na sala: não saísse puxapuxa a bandeja de pés-de-moleque, tivessem bom ponto os queimados, e não queimasse o espera-marido! O Benedito, cuja carapinha como que se avermelhava às lavaredas do forno, acabava de compor um pernil de porco e um peru recheado: com ar vitorioso olhava a feitura, e com tal entusiasmo, que os frangos, patos, perdizes e a paca dantes aviados não lhe mereciam sequer um reparo mais. A Marcelina, pressurosa como nunca, varrera tudo e tal qual como quem varre uma igreja: podiam-se ver, por gosto, os cachorros do teto, as vigotas e os próprios espigões, porque o asseio era tão completo que estavam com jeito de novos.

À hora do almoço, ninguém chegou à mesa: ninguém tinha fome, pois a idéia fixa de todos era a volta do doutorzinho. A caboclada havia resolvido perder um dia de serviço e rodeava o povo da casa, pedindo o que fazer, oferecendo adjutório; um baldeava água; outro arranjava palmas de cedro e ramas de bananeira, para se enfeitarem as dependências da morada; outra catava flores de caeté, de lírios, de espirradeira e de ipês; outro tentava uns arcos de triunfo carregados de fitas, que tremiam ao vento, e os arcos eram muito frágeis, por serem de cana do reino; outro, afinal, mais engraçado ou mais afetuoso que os restantes, espalhava pelo pátio e por um longo trecho da estrada, folhas de manga e de jasmins do cabo. 
Foi a essa hora que o pai do moço tornou do povoado. A primeira coisa que fez foi mandar ensilhar um cavalo baio-açafranado, que era bom demais: podia-se estar montado naquele baio com um copo d'água na mão, que a água nem bulia; passista legítimo, como aquele, decerto nunca se viu numas dez léguas em roda; então para levantar as mãos num terreno lançante, como ele, só ele mesmo - pois um cavalo braceiro assim até parecia impossível, tanto que o cavaleiro precisava ser toco, porque se fosse nervoso, ao tomar com as patas do animal nos estribos, caía pela certa; tinha o corpo cheio, estava um torresminho, luzidio que nem enganatico. No açafranado é que Valdóro havia de vir, e com pouco saiu o camarada que tinha de acompanhá-lo.

A Felipa do galinheiro escolhia os frangos maiores para molho-pardo e recheio, não obstante os que o Benedito aprontou: porque à última hora se viu que para o povaréu que aparecia eram necessárias, pelo menos, umas vinte cabeças. A ajudar a Felipa, rompeu um peva bulhento, pintando a saracura: aquilo pulava no pescoço ou na canela dos frangos, e fugissem! Naquele instante uns pares de parirus vieram beber no córguinho que passava ao fim do galinheiro - e a Felipa gritou para dentro da casa que até dava ares de ser de propósito, virem ali as pombinhas que Valdóro tanto apreciava, depois de se terem sumido por muitos dias e talvez meses! Não houve quem não concordasse com a Felipa.

Cantigas encantadoras se ouviam, cantadas por um terno de lavadeiras que ensaboavam e batiam roupa nas vizinhanças; houve um momento em que uma delas, a de peito mais limpo e de voz tão entoada que a gente cuidava estar escutando o som de uma flauta, disse uma quadra de amores que acabava trovando com seu doutor. E as outras lavadeiras então se riram; uma das três procurou saber:

- Pois você, Isa, ainda não se esqueceu do Valdóro? Não pense mais nele: fazendo das prateleiras de riba não a de ser pra nós, caipiras do mato. Largue mão disso!

- Mas o que hei de fazer - a Isa contraveio: - se o amor que tenho por ele a modos que cresce cada vez mais com a ausência? Eu quero esquecer-me: eu quero, mas não posso!

- Pode, é só querer. Você não sabe a distância que existe entre ele e você, agora que ele volta moço e formado: é um abismo, criatura!

A Isa deu de suspirar: pois não tinha certeza, mas como que adivinhava a impossibilidade de se amarem um rapagão dos trinques e uma rapariga sertaneja, que não sabia cumprimentar nem receber uma visita, e falava as palavras todas trocadas! São voltas que dá o mundo, são voltas que o mundo dá - é muita verdade o que diz esta trova! - ela 
cismava assim, - quando, no cume do morro da fazenda, se levantou a poeira, que havia de anunciar a chegada da comitiva.

Houve uma barafunda. A notícia correu à semelhança de um vento do sul, rápida e rumorosa. O povo aglomerou-se no terreiro, no pátio, às janelas e às portas: queriam todos ver com vinha o doutorzinho. E logo que ele apeou, junto à escadinha do casarão velho, e a mãe veio abraçá-lo, chorando de alegria, e o pai, muitas exclamações se ergueram de muitas partes:

- Olhai como ele está mudado!

- Como está magro, o pobre!

- Nos estudos a gente fica pálida: vejam só o rosto dele!

- Era tão risonho e vem tão sério, já se viu?

- E como vem cresçudo!

A Isa foi a última pessoa a dizer-lhe adeus. Quando ela lhe apareceu, vergonhosa, corada, e tremendo, Valdóro perguntou-lhe:

- Então, sou para você algum desconhecido, Isa? Dantes não era!

Ela aproximou-se, estendeu-lhe a mão direita, vexada demais, e nada pôde dizer. E parecia que um céu de felicidades se abrira de novo à coitada, só por ouvir do Valdóro uma frase amiga como os do passado. Afastou-se para um canto do pátio em que todos permaneciam ainda, e pegou a fuxicar as barras dum lenço; as fontes ruidavam-lhe tanto, e os ouvidos, que tinha medo de cair com uma vertigem. Chegou um momento em que, lembrando-se das admoestações das companheiras de havia pouco, pediu a Deus que, tal acontecesse, antes a fizesse cair ali mesmo e não alevantasse mais...

Para desmanchar o constrangimento que se apoderara de quase todos, só mesmo uma léria do Martinho. E foi realmente o Martinho quem acabou co meia tristeza que ensombrava o semblante daquele povo, clamando para o fundo da sua casa, que era perto:

- Repontem esses perus e marrequinhas pro galinheiro, porque o Valdóro já está na terra, e senão, temos gronga! 


\section{$\underline{\text { Análise do conto }}$}

"Seo doutor", dedicado ao pai de Valdomiro Silveira, é um conto relativamente longo que mescla narração em terceira pessoa com diálogos. A narração é desenvolvida em tom coloquial culto e os diálogos ora em coloquial culto, ora no falar caipira.

Nesse conto (que também pode ser considerado "uma quase crônica autobiográfica"), podemos notar uma boa mostra da busca de identificação do narrador-autor com o objeto principal de sua ficção, fórmula esta almejada, mas difícil, segundo Carmen Lydia, de Valdomiro obter com precisão, mesmo ele tendo firmado, desde sua juventude, o compromisso de conhecer e conservar a fala regional e a poesia sertaneja, trazendo-a para a literatura culta ${ }^{40}$. Um bom exemplo dessa busca é:

"Quando na fazenda se soube que Valdóro ia aos estudos, não houve quem não fechasse muxoxo e não levantasse ombreira, porque ninguém quis acreditar: um tal dizia que menino assim, que até os catorze anos não tomou tenência e é reinador e mexerendengo, foge das coisas sérias da vida, como o demo da cruz;"

$\mathrm{Na}$ passagem acima podemos observar algumas expressões regionalistas, como "fechasse muxoxo", "levantasse ombreira", "tomou tenência", "reinador", "mexerendengo" e "demo". Estas expressões convivem com a frase (erudita) "quando na fazenda se soube que Valdóro ia aos estudos". Mais uma vez podemos constatar a mistura de linguagens no discurso do narrador-autor.

Em relação ao enredo do conto, verifica-se que o narrador é um alter ego do autor que explicita traços autobiográficos, desde o nome do protagonista, Valdoro, na verdade o apelido de Valdomiro Silveira. Segundo sua filha Júnia Silveira Gonçalves, Valdomiro passou a ser conhecido como Valdóro da Soledade pelos caipiras de Santa Cruz do Rio Pardo, cidade para onde foi nomeado promotor público após formar-se em Ciências Jurídicas e Sociais em 1895. Nessa época Santa Cruz era um sertão. Lá, ele levou muito a sério seu trabalho, escreveu bastante, anotou com cuidado o "peregrino falar" das testemunhas, estudou Ornitologia e Botânica, freqüentou festas típicas sertanejas (os "assustados", as "funções" e os "pagodes") e saiu para caçar e pescar com os caipiras, "mais para ter o gosto de ouvir e aprender".

\footnotetext{
${ }^{40}$ DIAS, Carmen Lydia de Souza. Op. cit., p. 194.
} 
Valdomiro se tornou um "tropeiro sertanejo"41 o que nos mostra o grau de apego e respeito dele pelos caipiras.

Outro ponto importante na prosa deste regionalista diz respeito ao uso da expressão "seo doutor", como forma de tratamento por parte de pessoas simples e humildes ao se dirigirem a pessoas letradas, portadoras de diplomas socialmente bem valorizados, como os de médico e advogado. No que concerne a este conto, "seo doutor" é o tratamento endereçado pelos caipiras ao promotor público Valdomiro Silveira, conhecido por eles como Valdóro da Soledade.

A relação entre o homem letrado e o não-letrado é um motivo importante no conto. Por sinal, ela se constitui em motivo principal, na medida em que explicita as diferenças, e até mesmo semelhanças de cultura entre aquele que vai até a cidade "aos estudos" e os que vivem na fazenda.

O letrado, Valdóro, um dos herdeiros da fazenda, convive naturalmente com os caipiras, participando de festas, de caçadas e pescarias. Pode-se afirmar que possuía uma verdadeira alma sertaneja. Até mesmo sua fala se confundia com a dos caboclos, como podemos observar no diálogo entre ele e o caboclo Pedrinho:

"Da banda de fora do terreiro, o Pedrinho da Faxina gritou:

- Seo Valdóro, alevante-se, que as juntas já estão nas cangas e tudo se acha preparado: a da guia pintou a manta, mas concordou comigo, e aqui está de olhos virados pro chão.

- Sempre essa junta da guia foi teimosa e contadeira de história, - disse Valdóro, e mudou logo de tom -: ó, Pedrinho, você quererá tanto bem aos meus carneiros como eu lhes quero e tomará conta deles como se fosse eu mesmo?

- Sossegue que assim será!”

Podemos verificar a aproximação da linguagem do letrado em relação à do não-letrado através das palavras "contadeira" e "ó". O falar caipira está incorporado em Valdóro. Não de todo, pois guarda expressões do coloquialismo culto, tais como "você quererá tanto bem aos meus carneiros" e "eu lhes quero". Há, portanto, do ponto de vista formal da convivência narrador/personagens, um certo distanciamento entre ele, Valdóro e as personagens nãocultas.

\footnotetext{
${ }^{41}$ GONÇALVES, Júnia Silveira. "Notas Biográficas sobre Valdomiro Silveira”. In: SILVEIRA, Valdomiro. Mixuangos. $2^{\mathrm{a}}$ ed. Rio de Janeiro: Civilização Brasileira; Brasília, INL, 1975. p. XII.
} 
A respeito de "Seo doutor", observa Carmen Lydia de Souza Dias:

"No conto, ou quase crônica autobiográfica, "Seo doutor", de Mucufos, nota-se boa mostra dessa busca de identificação. É um texto de caráter memorial em que fica revelado o modo pelo qual o escritor assimilou, desde a infância, o espaço e a mentalidade do homem regional e o teor afetivo dessa aproximação. Esse texto leva simultaneamente a aquilatar o distanciamento que, a partir de certa fase da vida, se estabelece obrigatoriamente entre a sua própria forma de pensar o universo rural e a dos caboclos, surgindo então uma perspectiva adulta sobre o assunto. O caipira começa a ser ao mesmo tempo objeto de estudo e portador de recordações caras, estreitamente ligadas à intimidade psicológica do escritor”.

A identificação entre narrador, personagem culta e personagens caboclas não se dá por completo, na medida em que há uma mistura das falas culta e caipira, tanto no narrador quanto na personagem letrada, Valdóro.

A mistura das falas por parte do narrador, que podemos chamar de discurso híbrido, pode ser observada na seguinte passagem:

"Por este teor e forma, foram levando a conversa os diabos dos caboclos. Deu-lhes a notícia o Baltazar, o mais arteiro sujeito que o céu cobre, e criticou-a a seu bel-prazer: e desde que ele puxara a fieira, os demais agarraram direito no diz-que-diz-que. Entrecontaram-se façanhas de arrepiar os cabelos: o andar Valdóro pelos grotões, a campear ninhos de urus, o armar-se de bodoque para martirizar os guaxes no laranjal, o judiar dos poldros e o perseguir os piriás pelos brejos".

No trecho acima, pode-se observar a convivência de expressões da fala culta, tais como "Deu-lhes a notícia" e "criticou-a a seu bel-prazer", com expressões do falar caipira, tais como "os diabos dos caboclos" e "agarraram direito no diz-que-diz-que".

Depois de Valdóro ir "aos estudos", ele volta para a fazenda com o mesmo espírito com o qual saíra: o espírito caipira. Isto pode ser verificado na passagem abaixo, quando, depois de seis anos na cidade cursando Direito, Valdóro volta para reencontrar seu pessoal caboclo, assim como a amada Isa, que ficara a esperar quase sem nenhuma esperança de receber o amor do "doutorzinho":

“A Isa foi a última pessoa a dizer-lhe adeus. Quando ela lhe pareceu, vergonhosa, corada, e tremendo, Valdóro perguntou-lhe:

- Então, sou para você algum desconhecido, Isa? Dantes não era!

Ela aproximou-se, estendeu-lhe a mão direita, vexada demais, e nada pôde dizer. E parecia que um céu de felicidades se abrira de novo à coitada, só por ouvir do Valdóro uma frase amiga como as do passado". 
Valdóro, ao contrário do que diziam, não criara um "abismo" entre ele e Isa só porque voltara "moço e formado". Ele conservara, apesar de ter adquirido um saber erudito, sua alma caipira. Deste modo, ele resgata sua identidade caipira na alma, porém fica a dever um pouco do ponto de vista formal, na medida em que não consegue adequar de modo satisfatório seu discurso, que permanece híbrido até o final da estória.

O hibridismo do discurso, tanto do narador quanto da personagem Valdóro, assim como a caracterização engraçada e muito sentimental das personagens caipiras por parte do narrador, nos revela uma visão em boa parte deformada da realidade rural, que acaba sendo mostrada do ponto de vista pitoresco e caricatural. As peculiaridades estéticas das personagens acabam, em certa medida, se diluindo no exagero de seus atos e expressões. Podemos observar um pouco disto na passagem abaixo, que mostra a grande expectativa de Isa diante da volta de Valdóro:

\footnotetext{
"A Isa deu de suspirar: pois não tinha certeza, mas como que adivinhava a impossibilidade de se amarem um rapagão dos trinques e uma rapariga sertaneja, que não sabia cumprimentar nem receber uma visita, e falava as palavras todas trocadas! São voltas que dá o mundo, são voltas que o mundo dá - é muita verdade o que diz esta trova! - ela cismava assim, - quando, no cume do morro da fazenda, se levantou a poeira, que havia de anunciar a chegada da comitiva".
}

O sentimentalismo excessivo é revelado pela expressão "deu de suspirar". O efeito cômico nos é dado pela expressão "a impossibilidade de se amarem um rapagão dos trinques e uma rapariga sertaneja”. 


\section{$\underline{\text { Amaldiçoada }}^{42}$}

Fazia muito tempo que a noite caíra, uma noite de assustar, escura e cortada de relâmpagos; a ventania gritava pelo meio das laranjeiras, espalhando as flores que tinham rebentado aqueles dias mesmo; o rio, que de costume é sossegado ao fundo do quintal do Furtuoso, buzinava de fúria, levantando montes de água que vinham quebrar-se no porto c'um grandioso rumor: e escutava-se, através de barulhada toda, como se fossem gemidos e queixas, os mios duma coruja das grandes que andava desguaritada lá no alto do espigão que vem verter pro rio perto da ponte.

Sá Chiquinha estava esperando o Tito, encostada à janela do lado direito: cerrara as folhas da janela, ficara quieta duma vez, segurando a suspiração, de puro medo. Agora, ouvindo a matinada da coruja e reparando na escureza dos ares, teve uns repentes de tramelar a janela, e deitar-se, e morrer: parecia-lhe adivinhar um infortúnio, em tanta coisa triste que via. O Tito queria-lhe bem, decerto queria -, porque, pra um homem jurar contra sua alma, como ele jurava, só tendo muita fiança no juramento: mas o futuro aparecia-lhe do mesmo feitio que aquela noite denegrida.

- Como é que há de ser nhô pai? Pensava: e umas par de lágrimas garravam a correrlhe pelo rosto abaixo. Na verdade, o Nico de Souza, pai de sá Chiquinha, não desejava nem ver a sombra do Tito, nem ouvir falar-lhe no nome: ganhara-lhe ódio à toa, p'r amór de uns

\footnotetext{
${ }^{42}$ Nota CLSD: "O Estado de S. Paulo. São Paulo, 10 fev., 1902. (Escrito em Sta. Cruz do Rio Pardo, em 1897)". Nota da edição: "Amaldiçoada" suscita algumas questões em torno de sua publicação em periódico. O conto apareceu em $O$ Estado de S. Paulo a 10 de fevereiro de 1902 com o título "Maldiçoada", o mesmo de sua segunda versão, sem local e data de escritura, presente na pasta Mucufos. Porém, a primeira versão traz o título "Amaldiçoada", na pasta Originaes manuscriptos de papae (preciosíssimos), com a data de 26 de fevereiro de 1897 e sem indicação do local da escritura.

Na pasta Mucufos, o manuscrito é uma primeira versão e compõe-se de: autógrafo a tinta preta; 1 folha de papel almaço solta, pautada, papel branco escurecido pelo tempo $(32,5 \times 21,7 \mathrm{~cm})$, trazendo assinatura a tinta preta, título do texto, obra em que seria publicado e ano da escritura: "Valdomiro Silveira"/ "Maldiçoada"/ "Os caboclos"/ "1897", seguido de autógrafo a tinta preta com rasuras idem; 3 folhas de papel almaço, pautadas, papel branco escurecido pelo tempo $(32 \times 21,5 \mathrm{~cm})$, folhas sem numeração, escrita ocupando o anverso e o verso das folhas, assinatura no final: "Valdomiro Silveira". Em nota VS, a tinta preta, data de escritura no final: "26/2/1897".

Versão com desfecho diferente ao do apógrafo CLSD. O texto não saiu em Os caboclos como havia planejado inicialmente o escritor, que teria modificado o título da primeira para a segunda versão em função de sua proposta literária de registrar o falar caipira tal como ele se apresentava em seu tempo, o que se verifica desde o título "Maldiçoada" (ao invés de "Amaldiçoada"), de acordo com a forma oral e fora da norma culta, evidentemente.

Chamou-nos a atenção o fato de $O$ Estado de $S$. Paulo ter publicado o texto com o título da segunda versão, pois os textos que eram ali veiculados, tanto os eminentemente jornalísticos quanto os demais, pautavam-se exclusivamente pela norma culta. O jornal teria, de fato, respeitado o projeto estético e lingüístico do escritor.
} 
ditérios de gentinha de pouco mais ou menos, dessa gentinha que murmura dos outros sem mais que nem pra que. Desconfiado, isso o Nico de Souza vivia desde a festa de seo Batista, porque bem pôs atenção nos olhos doces que sá Chiquinha fazia pro Tito e o Tito fazia pra sá Chiquinha.

A moça fechava-não-fechava a janela, quando lhe bateu nos ouvidos o som de um pio de tico-tico: remancheou um bocadinho, como se estivesse resolvendo um bandão de coisas num momento só, inzonou co'a mão direita em riba do coração que funcionava louco de tudo, e depois, devagarzinho, pouco a pouco, afastou de junto do ombro a folha esquerda: seu vestido era branco e sem peso, vestido de nem um resguardo, quase que só de calor, e o vento aspro que veio de fora por um triz não a pinchou pra um canto do quarto.

Pregou os olhos no rumo da esquina, ali onde pára o poste de um lampião velho, divulgou um vulto encapotado que caminhava pra ela, viu-o vir chegando, chegando, até rentear c'a parede da casa, tendo pulado um tirãozinho de cerca baixa que havia na linha da frente: e daí, notando aquele vulto, já não sentiu mais o coração funcionar veloz e violento: pelo contrário, o coração foi-lhe adormecendo de tal jeito, que logo desmaiou que nem um passarinho, assim que vê frechar-se sobre ele um gavião desses quiris-quiris, c'as unhas prontas e as asas espontadas e o bico aberto numa proporção.

Sá Chiquinha caía-não-caía, quando o Tito lhe falou umas palavras de animação e de muita amizade: ora o que havia de ser, que tanto a amedrontava? A chegada de seu bem, ora o que havia de ser. Ele pegava-lhe na mão direita, a mão que ainda lhe permanecia em cima de seu peito, e ia dizendo certas prosas muito boas, muito mansinhas; no fim das contas, feito carinhos e mimos, ela recobrou a voz e respondeu-lhe no mesmo tom, em segredo, cochichado, um dilúvio de bonitezas. E já nem sabiam mais que a trovoada se formava ao longe e a tempestade havia de se despenhar por força: namorado, olhando os relâmpagos, mas porém perto da namorada, a mó’ que está vendo fogo de estúcia.

De repente um redomoinho rompeu pela rua, abalando as guainxumas e os fedegosos, rufando nas telhas, querendo quebrar as vidraças e arrombar as portas: o mio da coruja das grandes, comprido como nunca, morreu c'a primeira abalroada do redomoinho, ao fundo do covancão macota das terras do Ziquiel: e sá Chiquinha, tapando os olhos, tonta de assombro e de terror, ia ter uma vertige, se o Tito não a amparasse, dando-lhe um empuxão forte no corpo. A chuvarada desencadeou-se, ver um rio que desce pela cachoeira, grossa e atroadora; 
os relâmpagos riscavam toda a hora o céu, do nascente ao poente, cor de enxofre e sumindo como por encanto.

A água das enxurradas soluçava de raiva, rasgando-se tal e qual farrapos de renda, nas pedras e nos tijolos esparramados pela rua; o grito rouca dos trovões, correndo nas costas das montanhas, acabava pela claridade dos coriscos, e a claridade dos coriscos acabava pelo grito rouco dos trovões: e às vezes os coriscos, mostrando ares de zanga, davam pulos no meio das nuvens, amarelos e ligeiros, semelhando um terno de caninanas. Ao depois o firmamento voltava a ser feio que nem uma barra de chumbo sem fim.

De sopetão, num abrir e fechar d'olhos, a porta do quarto de sá Chiquinha escancarouse: a luz buliçosa duma candeia apareceu, tremendo ainda mais p'r amór de o vento; e apareceu a cabeça do Nico de Souza, branca, meia na sombra, adonde os olhos brilhavam como os dum gato escorraçado, nhá cesara, passando a mão pelos óculos, desatinada de espanto, mostrava as feições do rosto por cima do ombro do marido: e enquanto sumia o zunido fino da arage da chuva no covancão macota da outra banda do rio, e o rumor da tempestade assossegava seu pouco, também no quarto de sá Chiquinha se fez um silêncio de quarto de defunto.

O Nico de Souza botou a candeia num mancebo, a par co'a porta; fechou os olhos e tornou a abri-los, olhou e tornou a olhar, como se lhe parecesse impossível acontecer o que etava acontecendo; encostou-se ao portal, bambo e sem corage, segurou a mão de nhá Cesara e desatou a chorar; nhá cesara passou-lhe os braços em roda do pescoço e pranteou com feitio de lhe ter morrido alguém.

Sá Chiquinha perdera o sentido, e o Tito, assim que os velhos principiaram suas lástimas, pulou p'r a janela, com água até os joelhos, e foi ficar sondando arretirado, junto do poste do lampião. Tinha passado o mau tempo, a ventania sucumbira, apareceu a minguante num pedaço denegrido do céu. A água das enxurradas, rodando mais de vagar, com mais preguiça, murmurava baixico umas vozes de candonga. E a coruja das grandes, que se calara um tanto de espaço, miava agora outra vez, esquisito e soturno.

Foi então que Nico de Souza pôde desafogar-se:

- Saia de tudo, filha maldita! Acompanhe esse desgracionado que lhe roubou o seu coração! Nunca mais cruze os umbrais da porta desta casa! Saia d'ûa vez, filha maldiçoada!

Sá Chiquinha, como acordando dum sono de muitas horas, por efeito de um pesadelo, saltou pro meio do quarto e pôs as mãos em forma de cruz: 
- Não me toque, nhô pai: não me toque, porque eu não devo crime nem um!

E o Nico, sem dó e sem piadade, respondeu-lhe estas palavras:

- Saia, desgraçada, saia desta família que nunca viu ûa mancha como a que 'tá vendo!

Nada puderam seus peditórios, nada conseguiram seus rogos; por derradeiro, quando viu que não podia mais esperar cabida naquela casa, foi beijar a mão da mãe. Nhá Cesara retraiu-se, pranteando. Sá Chiquinha chegou ao oratório, adonde morava uma Nossa Senhora Aparecida de olhos cheios de bondade e capa azul trançada no corpo inteiro, ajoelhou-se, co'a garganta numa sufocação, tirou do oratório um ramo de palma benta e um arrelique de baetinha preta, e pegou a mexer a boca, rezando desanimadamente.

O Nico bradou-lhe espótico:

- Vá-se embora, juruveva da rua! Que ûa mulher como você nem pode e nem deve rezar! Vá-se embora, maldiçoada!

Sá Chiquinha saiu. Esperava-a na esquina o Tito, que a chamou por assobio; mas antes de se encontrar com ele, sá Chiquinha, que ar da noite a mó' que animara de soco, rugiu uma espécie de rugido horroroso que nem de fera, e disse:

- Maldiçoada é que eu não saio! Misericórdia!

Disparou no rumo do Rio Pardo, que lá em baixo, espumando e roncando, amostrava estar pelas turinas: e foi por causa de tamanha espumarada e roncaria que não se pôde ouvir o baque de sá Chiquinha naquele poção fundo do beco. A coruja das grandes remontara, miava agora no chato do espigão, com seus mios mais compridos, cada vez mais esquisito e soturno; e o pobre do Ziquiel, que há muito tempo está fora do juízo, veio a tão feias horas visitar a 
tapera $^{43}$ em que morou, e dava cada gargalhada tão alta, que subia até o chato do espigão e descia até a última corredeira da segunda volta do rio.

Nem bem amanheceu, já saiu gente em procura do corpo: aprontaram uma gamela c'uma vela dentro, acenderam a vela, e aquilo foi descendo feito uma pantasma pelo rio afora. Quando deu meio dia na cadeia, pouco antes, pouco depois, a gamela girou duas vezes perto dum canal que desemboca num mansão de quatro braças, pra cá um pouco do engenho, e parou direitinho na vizinhança duns guapés. A canoa da procura chegou, os homes bateram varejão pelos guapés, cutucaram as raízes, e depois, campeando bem por debaixo da gamela, encontraram sá Chiquinha, que assim que surgiu à flor d'água assombrou a todos, por estar tão desfigurada.

A canoa voltou, rio acima. Quando chegou ao porto do Nico e puseram a moça numa rede pra conduzirem pra casa de morada, era só grito e choro que se ouvia por toda a parte, de mulheres e crianças, gente que até não tinha nada c'o acontecido.

Tem daqui, tem dali, mais isto, mais aquilo, diziam mil coisas a respeito da finada; e o que maiormente havia de doer à pobrezinha (se quando se morre ainda se escura o que os mortais proferem), era dizerem que a morte não passava duma complicação. E rematavam por esta maneira:

- Não podia apanhar chuva, apanhou; tomou umidade, o sangue subiu-lhe à cabeça, a coitada por isso ficou demente...

O sol já estava a umas três braças pra mergulhar naquela morraria sem fim, quando saiu o enterro. A tarde era uma tarde triste, sem canto de passarinho, sem voz de ninguém p'r as ruas, sem vento que tremesse as árvores. Só uma tapena voava muito sereno em riba da

\footnotetext{
${ }^{43}$ Nota da edição: Segundo SOUZA, Bernardino José de. Op. cit., p. 309, tapera é um "conhecido termo de uso geral no Brasil e até nas repúblicas platinas, de procedência túpica: tab - aldeia e era - que foi, extinta, donde a tradução literal - aldeia extinta, povoação de outrora (Teodoro Sampaio). Assim costumavam denominar os ameríndios do Brasil e terras convizinhas do Sul as aldeias que a tribo abandonava, já quando vencida nas lutas com as confinantes, já em busca de melhor pescado, caça mais abundante, vida mais segura ou mais fácil. Desde o século xvi, entrou no linguajar dos conquistadores, dos negros e dos mestiços, a corrutela tapera para designar não só a aldeia, a maloca abandonada, mas também uma casa, choça, rancho, qualquer habitação do campo arruinada, abandonada, de regra em lugar ermo e soturno. Por extensão, ao depois, começou-se a chamar tapera ao estabelecimento que era completamente abandonado e em ruínas, no dizer de Beaurepaire-Rohan. Em nossas viagens pelos sertões da Bahia já ouvimos chamar tapera a uma vila ou arraial em grande e visível decadência. Precisamente, pois, o exato sentido de tapera é o de casa, no campo, arruinada e abandonada. Bela imagem do como se forma uma tapera dá-nos Darci Azambuja, à pág. 166 do seu No Galpão: 'A propriedade tocou a um parente longe, que arrendou o campo e não se importa com a casa. Hoje, quem passa na estrada, vê que ela se vai arruinando aos poucos, fechada, sem abrigar mais ninguém. O banco de pau despareceu, a latada de medressilva caiu, caíram as cercas de sarrafo, no telhado há um grande rombo. As chuvas e os ventos derrubaram o teto, primeiro, depois uma parede, e as portas, as janelas... E lentamente a casa ir-se-á tornando tapera, - que é uma saudade perdida no campo'. Não é menos eloqüente a seguinte estrofe de D. Aquino Correa, eminente prelado de Cuiabá, tirado do seu poemeto A Tapera, que lemos na Revista do Instituto Histórico de Mato Grosso".
} 
vila, fazendo vagarosamente suas curvas duma banda pra outra, co'a cauda ora aberta e ora fechada.

Um caminhante que tinha sabido da morte e olhava o enterro que ia passando, falou pra um dos que vinham mais atrás:

- No meu tempo, uma gente que se matava não tinha lugar no çumitério, ficava pra fora do sagrado.

Mas ninguém disse nada, o que tinha recebido a fala mal apenas teve como resposta um gesto de amargura e de sofrimento. E sobre a grande tristeza da tarde se foi cerrando o grande desespero da noite. 


\section{$\underline{\text { Análise do conto }}$}

Em "Amaldiçoada", assim como em "Rabicho", podemos encontrar, no plano do léxico, várias menções a animais e plantas, de teor regional. Alguns exemplos são: "quiris-quiris", "guainxumas", "fedegosos" e "caninanas".

Para Carmen Lydia de Souza Dias, “Amaldiçoada" é um dos melhores contos não publicados em livro de Valdomiro Silveira, pois não apresenta excesso de regionalismos, apostos, perífrases e palavras eruditas, como nos demais, além de não ser longo em demasia, como alguns outros ${ }^{44}$.

"Amaldiçoada" pode ser considerada uma narrativa dramática, na medida em que a personagem sá Chiquinha, depois de ser amaldiçoada pelo pai que a surpreendera no quarto de sua casa com namorado, suicida-se no Rio Pardo que, naquele momento, estava "espumando e roncando".

O conto é narrado parte no falar caipira e parte em coloquial culto (não mais somente em coloquial culto como em outros contos) e o diálogo entre as personagens ocorre em falar caipira. Isso pode ser observado na seguinte passagem:

\footnotetext{
"Sá Chiquinha, como acordando dum sono de muitas horas, por efeito de um pesadelo, saltou pro meio do quarto e pôs as mãos em forma de cruz:

- Não me toque, nhô pai: não me toque, porque eu não devo crime nenhum!

E o Nico, sem dó e sem piadade, respondeu-lhe estas palavras:

- Saia, desgraçada, saia desta família que nunca viu ûa mancha como a que 'tá vendo!'

Nada puderam seus peditórios, nada conseguiram seus rogos: por derradeiro, quando viu que não podia mais esperar cabida naquela casa, foi beijar a mão da mãe. Nhá Cesara retraiu-se, pranteando. Sá Chiquinha chegou ao oratório, adonde morava uma Nossa Senhora Aparecida de olhos cheios de bondade e capa azul trançada no corpo inteiro, ajoelhou-se, co'a garganta numa sufocação, tirou do oratório um ramo de palma benta e um arrelique de baetinha preta, e pegou a mexer a boca, rezando desanimadamente".
}

Ao narrador, no trecho acima, incorporou em seu discurso alguns termos de teor regional, tais como "cabida" e "adonde". Em contrapartida, faz uso de algumas palavras da norma culta, tais como "peditórios” e "rogos”. Dá para notar, através dos arcaísmos e regionalismos

\footnotetext{
${ }^{44}$ DIAS, Carmen Lydia de Souza. Op. cit., p. 196-197.
} 
presentes em todo o conto, que o narrador-autor penetra um pouco mais no universo lingüístico do caipira para tentar se aproximar ainda mais de seu objeto de representação.

Um dos motivos principais de "Amaldiçoada" é a violência no seio familiar, que vem à reboque do tema: o machismo associado ao autoritarismo patriarcal. A ordem do pai, carregada de uma grande dose de moralismo associado a valores religiosos bem arraigados (no caso os do catolicismo, pois era a religião predominante na sociedade rural da época), abala de tal modo a heroína levando-a ao suicídio. A religião, aliás, é outro motivo principal no conto, na medida em que alguns símbolos do catolicismo, tais como o "oratório", "um ramo de palma benta" e "um arrelique de baetinha preta", são mencionados.

A agressão séria, no conto, aparece associada à quebra de uma regra moral tacitamente incorporada à família patriarcal católica, isto é, o tabu da virgindade. Violar esta regra significa um pecado muito grave. Daí a ira e a violência, ainda que verbal, do pai de sá Chiquinha. Era ele quem dominava a família e a filha devia se sujeitar a ele.

A configuração do mal, que aparece no texto como um outro motivo principal, está intimamente associada à idéia de pecado. Ao violar as regras morais da família, sá Chiquinha causa um mal terrível ao seu lar, provoca a ira do pai e é expulsa, "maldiçoada"; deve ser afastada do convívio familiar. E ela própria se convence disso, punindo-se com a morte.

A reunião da comunidade, em "Amaldiçoada" se constitui em um motivo secundário, na medida em que é ocasional e totalmente imprevista, resultante de uma ocorrência inusitada na rotina sertaneja. No conto, o povo se reúne para presenciar a cena triste do resgate do corpo de sá Chiquinha, no Rio Pardo. É o que relata o narrador:

\footnotetext{
"Nem bem amanheceu, já saiu gente em procura do corpo: aprontaram uma gamela c'uma vela dentro, acenderam a vela, e aquilo foi descendo feito uma pantasma pelo rio afora".
}

\section{Continuando:}

“A canoa voltou, rio acima. Quando chegou ao porto do Nico e puseram a moça numa rede pra conduzirem pra casa de morada, era só grito e choro que se ouvia por toda a parte, de mulheres e crianças, gente que até não tinha nada c'o acontecido". 


\section{$\underline{\text { Bocó-de-mola }}^{45} 46$}

Bem se diz que casamento com parentage dá sempre mau resultado.pois ali estava aquele casal tão unido - o Joaquim Chico e nhá Loriana, primos entre si -, que teve a infelicidade de ver no meio dos outros um filho tapera duma vez, a quem deram o nome de Teófilo. O ribeirão grande inteiro tinha dó dos coitados, por vista disso: o que não proibiu certa gentinha de pouco mais ou menos botar no triste de songa-monga o apelido de Bocó-demola.

Ora, aquilo pegou como bichas, e só com esse apelido é que o conheciam nas redondezas. Os catatauzinhos de longe gritavam, quando o viam: - ó Bocó-de-mola! - e o rapaz irava que nem um tigre, chegava a enchouriçar o pescoço e rugir umas ameaças de abalar céus e terra: os catatauzinhos fugiam numa disparada, se aquele vulto estrangolado dava de correr pro lado deles; e se percebiam que a coisa estava com jeito de amargar, abrandavam a voz e diziam, entreparando:

- Ó Teórfo! Pra que tamanha zanga?

Ele sustava a carreira, também com aqueles olhos enormes granados nos provocadores, e vendo que eles não tinham no semblante expressão de caçoada, voltava. Mas não lhe bulissem mais, em seguida, que então perdia as estribeiras e voava em riba dos tais, cego e fungando de raiva: e derrubava cada paulada de criar bicho, a ponto de ser necessário, às vezes, que Joaquim ou nhá Loriana acudisse ao que gemia uns pescoções, caía e levantavase, recolhia, e ficava a um canto da casa, mudo como um peixe: sabe Deus que craminholas se remexiam naquela cabeça!

O Joaquim Chico, assim que o menino agarrou os doze anos, reinou, reinou, para descobrir um meio de acabar com tanto disparate. Afinal, a paciência dum homem não é de mesma largura e fundura que o rio pardo, e um dia se esgota: e era preciso dar um paradeiro a semelhantes desatinos! Onde é que já se viu agora um manguarão de doze anos correr encambulhado com os outros, vestido de camisola e mais vadio que bicho-preguiça? Foi

\footnotetext{
${ }^{45}$ Nota CLSD: “Gazeta de Notícias. Rio de Janeiro, 1,2 e 3 jun., 1897. (Escrito em Sta. Cruz do Rio Pardo)”.

46 Nota da edição: Datiloscrito original, fita preta, rasuras a lápis preto e a tinta preta, 10 folhas, papel branco escurecido pelo tempo $(27,5 \times 20,5 \mathrm{~cm})$, numeradas: 2-10, juntadas com 2 grampos, escrita ocupando o anverso das 10 folhas, s.a., s.l. e s.d. O apógrafo de CLSD indica publicação no periódico Gazeta de Notícias, do Rio de Janeiro, em 1, 2 e 3 de junho, 1897, e a escritura do conto em Santa Cruz do Rio Pardo.
} 
castigo do céu, decerto, mas pra tudo se dá remédio, menos pra morte -, e o Joaquim, depois de muito excogitar, descobriu que o remédio ali era a perova e o tala: havia da endireitar o filho a poder de couro e pancadaria velha.

Se bem pensou, melhor fez. Toda manhã, logo que o sol apontava, ia cutucar o Teófilo com uma guaçatonga fina, clamada que aquilo não era hora de tamanho bezerro estar no lugar quente, e se apinchasse do catre e fosse trabalhar, que quem não trabalha tem o que comer.

O Teófilo esbugalhava mais brutos olhos, cujo branco parecia tocada de azul, e pulava meio caído, quase sempre: engolia às carreiras uma tigela de café com leite misturado com farinha de milho, e seguia pra um rocio que o pai andava fabricando, dali a umas trezentas braças: e se seguia, era porque o pai lá o ia repontando.

Os outros, louvado Deus, davam conta do eito, porque tinham bom natural e medo da guasca: mas o diabo do samonga a modo que cada vez emperrava mais, cada vez ficava mais perrengue e mamparreiro. O tala e o pau cantavam-lhe em riba: qual! - aquilo era mesmo castigo que viera do céu ao Joaquim Chico e à nhá Loriana, porque do contrário já teria havido alguma arrumação! - e o rapaz beirava o quinze anos sem que, que melhorasse, ao mesmo um pouco do juízo, nem tivesse propensão pro serviço. Houve noites áfias que eles gastaram só em falar no filho e fazer cada lamúria capaz de esmoer o coração da gente que os ouvisse: e nhá Loriana aconselhava sempre ao marido não batesse tanto no desgraçadinho do menino, que afinal não tinha culpa de ser assim.

O Joaquim concordava, arrependia-se, prometia não cometer mais tão grande malvadeza; ao romper do dia tratava de acordar então o Teófilo, porém com toda a brandura, dava-lhe um cuietê cheio de leite com farinha de moinho (de munho chamada), e entregavalhe a ferramenta: ele pegava-se, que a tudo uma pessoa se acostuma neste mundo! - troteava pro rocio, tropicando aqui, tropicando acolá, caindo mais longe, até que o Joaquim ficava pelas turinas e já o fazia apresar-se a pontapés e cachações; - e no eito era um nunca mais acabar! Os outros, bendita fosse a providência! - continuavam destorcidos como dantes.

Malhou em ferro frio o Joaquim, porque lucrou tanto como coisa nenhuma: o entendimento do Bocó-de-mola parecia piorar cada vez mais; ultimamente se fizera no costume de resmungar pelos cantos, abrindo um bocão terrível, donde os dentes rompiam chatos escuros como os de um animal erado: e ninguém podia compreender aqueles resmungos e o que significava aquele abrir de boca com tamanha ferocidade. Tão feio se 
tornava ele, em tais ocasiões, que a própria irmandade pegava chão, quando o outro principiava com semelhante esquisitice.

Aí então é que o cacete trabalhava ás deveras. O cacete e uns três metros de fumo dobrado e trançado, pois chegou pra todos a convicção que o diabo entrara no corpo do sarambé. Morava na ilha grande uma benzedeira por nome a macaca: essa foi chamada, olhou o sintoma da cara, correu cruzes pelo peito do endemoninhado, de cima pra baixo, de baixo pra cima e nada conseguiu. O tio Procópio, um negro escangalha que assistia na mumbuca e tinha fama de meio feiticeiro, passou a mão em quanta veinha havia no Teófilo, e ficou tudo na mesma, no ora veja.

O Joaquim começou a desesperar. E não era pra menos: um pai de oito famílias, que precisava fazer hoje o que vestir e comer e beber amanhã, atrapalhado com um imbecil em casa, que além de imbecil vivia com o rabudo dentro de si, é brinquedo? A coitada da nhá Loriana, essa ajoelhava a nossa senhora da conceição, rezava, chorava, chorava mais, rezava mais, puxava terço, fazia promessa, que era até da gente sentir um nó na garganta e uma quentura nos olhos!

Tentaram todo remédio que lhe aconselharam, toda raiz importante, chás de arruda de erva-cidreira, infusões de palma benta, beberagens de noz-vômica e de losna: pregavam-lhe ao pescoço uma penca de rosários e cruzinhas, mãos de coral, orações encobertas, um dilúvio de miuçalhas! Mandaram-lhe que lavasse de joelhos uma temporada comprida, persignandose de minuto em minuto, olhando a cruz de nosso senhor morto: e pediam misericórdia por ele, que não sabia pedir - mas tudo dava em três vezes nada, nada é.

Nhá Loriana fez companhia ao marido: ficou tão cheia de esperanças como um sapuvuçu bem seco está cheio de folhas... E então era só um chorar aqui e outro chorar mais além, numa demasia que chegava a ser uma lástima.

Apareceu na vila, por esse tempo, um doutor de quem diziam maravilhas: que tinha posto são de tudo um caboclo tantã há muitos anos, o Zeca Piramboia, o qual endoideceu p'r amór da fugida da mulher; que curou os ataques bravos dum menino já deste porte, o Antoninho, filho do Chico Trombeta, que residia em S. Pedro; que tirou o mau olhado duma criança muito bonita, lá pros lados do criciumal: e uma infinidade de milagres mais.

Foi um próprio buscar o doutor, um dia que rapaz amanheceu mais esquentado e com os olhos vermelhos. O doutor veio, examinou-o, perguntou se no meio dos tios ou dos avós não tinha havido nenhuma gente que sofresse de gota-coral ou de convulsões fortes; se ele era 
assim desde pequeno: e por último pediu que o fizessem caminhar um bocado, pra ver se não trocava ou não bambeava as pernas.

Depois o doutor tirou uma carteira do bolso, tirou um quarto de papel, tirou um lápis e escreveu uma receita com uns nomes arrevesados, uns brometos de potássio e outras drogas desconhecidas; ensinou que era preciso todo o cuidado com o doente; que o doente devia passear, distrair-se, dormir bem, ter alimentação direita e muita vigia em riba dele; porque a doença não deixava de ser perigosa e nalgum momento podia vir um acesso furioso.

O doutor foi-se embora, gabado como um santo, por mostrar ser tão bom curandeiro, que até indagava da vida dos outros, dos pais e dos avós dos outros una moda que ninguém usara ainda por todo este matão desgrenhado. E a esperança, voltou cheia de fortidão, alegrando a casa inteira: porque eles, a dizer verdade, queriam bem demais ao Teófilo.

Trato mais bom que o que lhe deram, daí por diante, só no palácio dum rei mouro. Nem bem ele pulava da cama, já lhe traziam chocolates de agrião, ou gemadas de leite, ou caldos de mocotós de vaca; no almoço arrumavam-lhe um prato que era una montanha; no jantar uma sopeira que era um a lagoa, e uma travessa mais empinada que a serra do Jacarézinho, e cada pires de doce mais doce que mandaçaia; de noite, uma terrina de leite, uma dúzia de bolinhos de polvilho, ou um bolão de fubá, ou sonhos de farinha de trigo. Só vendo!

A princípio, notaram no semblante do rapaz uns toques de sangue, umas cores boas que vinham vindo. Mas não demoraram muito as boas cores: apareceram e desapareceram logo. O rapaz afinou e vez de engordar, ficou feito um varapau, de magro; apontaram-lhe por debaixo dos olhos uns riscos azulados, assim a modos de florzinha de criciúma ${ }^{47}$ já quase murcha; os olhos, esses então tomaram um tom sem propósito de olhos de filho de Deus. Já daí o desespero cresceu novamente no ânimo do pai e no ânimo da mãe: e como cresceu! rijo e depressa que era mesmo pra matar se não fosse a ajuda do céu!

Nesse meio tempo o compadre Joaquim João teimou com eles que doença daquele sintoma se cura mas é a varadas de fumo: porque se a coisa é de mamparra, a esfrega esperta o sujeito; se a coisa é produto de artes do demônio, o demônio não resiste às pancadas do fumo.

\footnotetext{
${ }^{47}$ Nota da edição: Segundo SOUZA, Bernardino José de. Op. cit., p. 123, a criciúma, que cresce em grande quantidade no criciumal, “(...), segundo Lima Figueiredo, em seu livro Oeste Paranaense, é uma gramínea também conhecida pelo nome de taquarinha ou taquarembó, a qual lasca de tal maneira que constitui afiadíssima faca, produzindo perigosos talhos".
} 
Este compadre Joaquim João tinha sido sempre muito amigo da casa: e não é que de certo ele estava com a razão toda de seu lado? Assim pensou o Joaquim Chico, já acompanhado por nhá Loriana. Pra encurtar conversas: o doutor o que fez? Contou gronga à toa, umas prosas bonitas que não deram resultados! E de prosas não se vive neste vale de lágrimas.

Foi o Joaquim João falar e o Joaquim Chico ouvir como quem ouve um pedaço de livro santo: no dia seguinte puxou o filho a trambolhões, assim que o dia clareou, pôs-lhe a ferramenta na mão e calcou-lhe pra experiência uma dúzia de varadas. Não, que era necessário levar a tarefa de fio a pavio, e nunca mais com panos quentes. Se fosse uma macacoa passageira, vá lá que se descuidasse, mas com um estado sério não se brinca: às vezes uma defluxão dá pra acabar com a vida dum pobre, quando mais um sofrimento assim, que fazia o rapaz definhar de dia pra dia! O negócio não ia direito, nem um pouco!

E o Teófilo cada vez mais rebelde: não corria como de primeiro, agora; pelo contrário, ia indo pela estrada devagarinho, feito uma formiga, apesar do pai não descontinuar com aquela música.

Todos se assombravam, vendo tamanho sossego no meio de tamanha surra: uns tinham muita dó do infeliz, que um cristão, agüentando toda aquela judiaria, sem boca pra soltar um soluço, é porque tem muita força de vontade; outros ruminavam que tudo não passava de mangação do tal chifrudo que estava escondido lá dentro e tomara conta do corpo com tão grande poder, que o corpo nem não sentiu mais nada do mundo.

Histórias! Pois, a falar verdade, o Teófilo andava quieto a mais não poder; mas quem lhe reparasse no rosto, quando o pai vinha atropelá-lo, veria o rosto mudar de cor duma hora pra a outra e uma placa de chumbo prega-se em cada face, com um jeito que até lhe dava ares de bicho selvage. Tanto, que uma vez nhá Loriana, que se achava perto dele, no já falado rocio, e na ocasião em que o Joaquim Chico ia bater nele, largou um pulo que nem o duma lebre, de ligeiro, só de terror daquela feição desfigurada.

Vida sem assento, assim, não podia durar muito tempo, e já durava demais. Um dia, cruz, credo! Pra aqui e mais pra ali! - o diabo a mó' que não teve mais pachorra e entendeu de botar as manguinhas de fora.

O admirável é que a barra da madrugada rompeu bonita como um vestido que sea Gertrudes do Ribeirão tem, cor de rosa duma vez. Um centinho manso cochichava com os galhos e com os ramos e os galhos e os ramos pareciam rir, abaixando-se, erguendo-se, 
encontrando-se uns com os outros. Um dilúvio de urus cantava pelo mato fora. Madrugada que nem essa não é própria pra desastres e esta foi.

O Joaquim Chico de certo acordou com elas suspendidas: rolou da cama tal e qual um embrulho, vestiu-se às carreiras, pegou a vara de fumo e um rabo-de-tatu desta proporção -, e correu pra cama do Teófilo, enfiando-lhe a ponta duma azagaia no braço direito, até que ele deu acordo de si, assustado e tremendo. E o Joaquim Chico buzinou de raiva, porque Teófilo deu de coçar o corpo, que tinha mais fim nem acabamento: por último o rapaz saiu, quase maio arrastado, com os olhos papudos do sono e o corpo mole-mole ainda.

O café não tardou, que nhá Loriana percebeu loguinho os azeites do marido: e mal o café rodou pela garganta abaixo do Joaquim Chico, o Joaquim Chico segurou a enxada e os instrumentos da pancadaria, e fez caminho, tangendo o filho. Os restantes seguiam mais de longe, conversando em voz abafada; e um deles, o caçula, toda hora estremecia, falando baixo: - faça florescer as pedras! - porque era a morte que estava toda hora passando por ele. Chegaram a pôr sentido em tanto estremecimento do Joaquinzinho; mas o cultivo mostrou a cara no rasgão da mata-virge e ninguém mais pensou naquilo. Com certeza era friage.

Até a umas cinco braças de sol o serviço correu sem atrapalhação, bem cerrado como sempre. Era uma quebra de milho que precisava ser feita quando antes, porque os queixadas andavam saindo na roça, e quando saem numa roça vai tudo raso. Tinham já derrubado uns oito carros, e o Teófilo ajudava, quando o Joaquim Chico mandou destampar o almoço, que a fome dissera umas novidades lá no estômago dele. Procuraram uma aguada anexa à plantação, estenderam uma toalha à beira mesmo, e cada um puxou sua colher pra fazer pela vida.

A fome do Teófilo - ê! fome! - parceira fome canina! Aquilo foi só abrirem a toalha e já ele cair com as mãos abertas em cima da marmita, com uma violência que nem se pode dizer. Um pobre de estrada, bem miserável e sequinho, que tivesse passado três dias em jejum, pela certa não havia de fazer tão má figura como aquela! E o Joaquim Chico irou, mordeu os beiços de tanta fúria, passou os dedos abertos pelos cabelos, largou uns gritos danados:

- Por que é que você está com tamanha esganação, ô diabo?

E trunfou-lhe a vara de fumo às direitas, descanjicou as costas do desgraçado assim como quem malha feijão.

Pois foi nesse momento que a paciência do Teófilo não pôde mais aturar. Um pote em baixo da bica, meio em falso, fica de pé até certa proporção, mas quando se enche de todo, cai 
por força: a paciência do Teófilo rodou por este feito. Ele garrou um cacete de guaiuvira que servia de bastão pro Joaquinzinho, frenteou com o pai, e descarregou-lhe o pau a risco de vida. A rapaziada, presenciando uma coisa tão impossível, ganhou rumo do mato-grosso: e ninguém pôde valer ao Joaquim Chico em tal inficionado pedaço.

As bordoadas caíam a torto e a direito, pela testa, pelas orelhas, pelo nariz, pela boca, pelos ombros, pelos braços, com um vigor que nem tinha mostra de ser de gente da terra: e o Joaquim Chico uivava de dor, caído no chão e torcendo-se, ensangüentado a toalha e a agüinha com tanto desperdício de sangue, que chegou um instante em que só se via correr mesmo sangue em lugar de água.

Quando ele desfaleceu, então, o Teófilo, com os olhos escancarados e os dentes unidos, botou-lhe um joelho no peito e enfiou os três dedos maiores de cada mão numa brecha do alto da cabeça; puxou, que puxou, com quanto tutano tinha; vendo que não arranjava nada, pegou uma lasca de lenha, para servir de cunha, e rebateu-a com a guaiuvira; depois tirou-a, botou de novo as mãos na brecha, sacou dos dois lados, e a cabeça partiu-se de meio a meio: escorreu um chorinho vermelho, de entre os miolos, e o Teófilo agachou-se ainda, chupou-o, pra logo em seguida gargarejá-lo fora; meneou o corpo pro corgo e sentou-se junto da sangueira, falando com um porte de voz que semelhava rugido sobre rugido:

- Agora 'ocê não me judia mais! Agora 'ocê não me judia mais! Agora 'ocê não me judia mais! 


\section{Análise do conto}

"Bocó-de-mola" faz parte do grupo dos contos estilisticamente imaturos, tais como "Castigo do céu", "Soneira brava", "Reis" e "Forte teima!". É um daqueles contos onde o dialeto não foi adequado ao caso, que precisa dele para se constituir como experiência humana e regional esteticamente válida.

Trata-se de um conto quase que totalmente narrado em coloquial culto e apresenta pouquíssimos diálogos. É um daqueles contos experimentais onde Valdomiro provavelmente o tenha usado como repositório do "caso" para posterior feitura.

"Bocó-de-mola" pertence ao grupo dos contos onde mais aparecem arcaísmos. Fazem parte desse grupo, também, os seguintes contos: "Mutirão", “À hora da prisão”, “João Maçarico”, "Quebrante”, “Ânsia antiga", "Soberbia", "Soneira brava”, "Reis", "Forte teima!”, "Os guaxes", "Na rua do Bosque" e "Paixão de raiz".

Entre os arcaísmos, destacam-se: "parentage", "home", "judiaria" e "selvage". Há, também, algumas locuções arcaicas, tais como "a mó que" (significando "a modo que”) e "p’r amór da" (significando "por amor da").

Outro aspecto relevante em "Bocó-de-mola" é que o texto se constitui em um bom exemplo de rusticidade familiar. Aqui cabem algumas observações feitas por Carmen Lydia de Souza Dias:

“Assim, a personagem Joaquim Chico, pai do Teófilo, pensava que "havia de endireitar o filho a poder de couro e pancadaria velha", portanto, "o tala e o pau cantavam-lhe em riba". Este longo e cruento conto em estilo quase todo dialetal, já a nível do discurso narrativo, constitui verdadeiro repositório de elementos concernentes ao estudo da rusticidade cabocla em seu sentido amplo. Ele próprio nos introduz ao enfoque de outros temas decorrentes, já que, entre motivos passíveis de auxiliarem na reconstrução do panorama cultural, apresenta também o da superstição e do curandeirismo, secundados pela medicina caseira e pelas orações católicas. Evoca a fase da civilização caipira em que, não obstante o seu gradual distanciamento da natureza, em virtude da aceleração do ritmo de trabalho e dependência maior dos centros urbanos, o caipira ainda estaria mais ou menos integrado a um grande sistema que é, ao mesmo tempo, natural, social e sobrenatural. Fase em que existe, embora já ameaçada pela urbanização, aquela ligação estreita entre as representações religiosas com a existência prática, material, fusão indiscutida da prece com a simpatia, do gesto mental com o materialmente simbólico" ${ }^{, 48}$.

\footnotetext{
${ }^{48}$ DIAS, Carmen Lydia de Souza. Op. cit., p. 144.
} 
$\mathrm{Na}$ rusticidade inclui-se como um dos motivos principais ${ }^{49}$ de "Bocó-de-mola", a violência no âmbito familiar, na sociedade rural do final do século XIX estudada aliás por Maria Sylvia de Carvalho Franco:

“Mesmo nas relações que são apontadas como o protótipo do modelo comunitário - as relações de família - obseva-se a violência incorporada, com alguma regularidade, às formas de ajustamento. Também nesta área de relações sociais, a luta não resulta de motivos ou de circunstâncias que, por sua excepcional relevância, quebrem o consenso harmonioso e levem à oposição. Agressões sérias aparecem associadas à rotina doméstica" ${ }^{, 50}$.

Porém a incidência de crimes envolvendo pais e filhos era menos freqüente entre cunhados, sogros e genros, por exemplo. Também entre pessoas com graus de parentesco mais distantes, como tios, sobrinhos e primos, não ocorriam muitas mortes, conforme examinou a ensaísta.

$\mathrm{Na}$ época da escrita do conto, a sociedade brasileira se sustentava sobre uma forte estrutura patriarcal, isto é, o pai era a figura mais importante no seio familiar. Como conseqüência desta estrutura, havia um marcante sistema de dominação onde a esposa e os filhos se sujeitavam à autoridade do marido. Assim afirma Maria Sylvia de Carvalho Franco:

\begin{abstract}
"A continuidade e o funcionamento regular das associações estabelecidas com esses alicerces foram garantidos por um princípio de dominação, expresso pela sujeição dos jovens aos mais velhos e pela observância de convenções que regulamentavam a conduta. De modo coerente com essas normas, em sua estrutura estavam claramente definidas as posições, os papéis e as linhas de autoridade, hierarquizadas as distâncias sociais e formalizadas as relações de seus membros. A integração de um grupo desse tipo depende pouco de sentimentos de identidade afetivamente alicerçados. Com maior nitidez vê-se o fundamento tradicional da fidelidade entre seus membros, conjugado a um poderoso vínculo definido pela situação de interesses. Ambos garantiram, articulados, a preservação e o equilíbrio do grupo familiar, a despeito das insatisfações geradas numa instituição em que os problemas pessoais foram de todo irrelevantes" ${ }^{\prime 51}$.
\end{abstract}

\footnotetext{
${ }^{49}$ De acordo com DIAS, Carmen Lydia de Souza. Paixão de raiz: Valdomiro Silveira e o regionalismo. São Paulo: Ática, 1984. nota No2, p. 76, comentando KAYSER, Wolfgang. Análise e interpretação da obra literária. Trad. Paulo Quintela. Coimbra: Armênio Amado, 1970. v. 1, p. 80, motivos "são situações humanas típicas e significativas, geradoras da tensão que move as personagens à ação".

${ }^{50}$ FRANCO, Maria Sylvia de Carvalho. Op. cit., p. 40.

${ }^{51}$ Op. cit., p. 42.
} 
A citação acima explica, em boa medida, o quanto o filho devia se sujeitar ao pai e, também, o quanto o primeiro devia servir como mão-de-obra no auxílio dos interesses econômicos do segundo. No caso do conto, a força de trabalho do filho ultrapassava o interesse puro e simples de domínio e exploração. Havia uma necessidade premente de sobrevivência, pois a família era grande e era preciso que Teófilo ajudasse seu pai no trabalho para o sustento do grupo. Porém a ânsia pela ajuda do filho era tamanha que o pai não respeitava e passava por cima dos problemas físicos de Teófilo. Joaquim Chico passava por cima de qualquer sentimento de carinho e de compaixão que pudesse experimentar por Teófilo.

O final trágico do conto mostra a força dos traumas armazenados no inconsciente humano, os quais podem emergir. 


\section{$\underline{\text { João Maçarico }}^{52} 53$}

Já se viu só? Pois o João Maçarico, um homem de respeito, que vivia no ermo, mourejando como lhe permitiam as forças dos cinqüenta anos, foi dar então em velho gaiteiro? Este mundo anda de pernas pro ar, não tem dúvida! Quem havia de dizer que um filho de Deus ajuizado como ele, que nunca apreciou as folias do arraial, nem as do mato, virou pândego e saído feito um moço de pouca idade? Se não foi feitiçaria que lhe fizeram, sem dúvida não passava de tramóia do coisa-ruim.

Magro e seco desde menino, meio arcado até, com um senhor nariz que parecia um peixe campineiro, fino e espontado, mereceu o apelido do monjolinho, um pássaro tísico por natureza e de andar duvidoso como o de João mesmo. E esse ditado dum cearense, que teve com ele uma rusga onça, mas contudo só bate-boca, ficou-lhe agarrado nas costas e nunca mais largou. Também, de certo prazo pra diante, o dono do nome a mó’ que não se importava mais que lhe chamasse por tal jeito. Quando gritavam de longe: ó João Maçarico? - ele voltava logo a cara escorrupichada, atendendo. Afinal um conhecimento assim não é que faz dor na gente!

Nunca teve pensão de casa, quando se achou de ponto: olhava as moças do tempo com certa maneira de desprezo, desdenhando, não porque fosse um grande sujeito, rico ou muito bonito, mas porque não encontrava nem uma da sua simpatia; acrescentava que isto de se amarrar um a uma por toda a vida é acontecimento que nasce de gostos iguais. Embora houvesse um tal Nico da Venda, que lhe queria empurrar a filha, uma morena escanelada de olhos espertos de mais, e a viúva de um Chico Mogango que punha em riba dele vista cobiçosa de tudo, não ganhou rumo, não tinha embocadura, e ladeou que nem um lambari no açude, nem bem se vai pôr a mão n’água.

O Nico da Venda, morador por ali assim onde hoje é a água espraiada, quando trazia o seu pra capela, aos domingos e dias santificados, aconselhava-o sempre:

- Olhe, nhô João: um homem que quer ter sossego e paz na vida, só casado: 'tá livre de apanhar uma chumbada, em autos alheios, ou de fazer uma mal-feita numa casa de

\footnotetext{
${ }^{52}$ Nota CLSD: “O Estado de S. Paulo. São Paulo, $1^{\circ}$ fev., 1902. (Escrito em Casa Branca, em 1902)”.

53 Nota da edição: O manuscrito possui versões nas pastas Mucufos e Originaes manuscriptos de Papae (preciosíssimos).
} 
qualquer picanha à toa. Despois, chegando a velhice, fica-se adoentado, sem força e quase sempre sem corage, e é uma boa mulher que serve de alívio e consolo, conversando com a gente, arranjando uma mezinha, um caldo, um pires de arroz-doce.

Mas o danado foi sempre cabeçudo: respondia pro outro que isso era muita verdade, muito certo, e no entretanto que, pra se dar semelhante passo, é preciso ter bons haveres, algum peculiozinho guardado pras horas de percisão, que vêm mesmo, mais cedo ou mais tarde. Embirrinchou, pode-se dizer, estaqueou naquela resolução, e não campeou noiva, apesar que, segundo o que afiançava por aqui um fulano Tucunduva, mulher é mais barato que égua - porque não hai cabocla que não case e poucos hai que tenham posses pra comprar uma catirina. E não houve na praça de São Pedro, nem nas cercanias, caboclo que conseguisse amolecer aquele coração de pedra.

Ora quem fala paga. O João Maçarico tinha-se gabado que não havia de tomar banhos de igreja, a mó' que pissuía reza encoberta para essa tenção, agora chegou-lhe a vez: viajando pelo cinza abaixo, em canoa, caçando as antas e os veados do sertão fundo, contou-lhe um bugre velho, um caiuá manso, que o poder da mocidade voltava com uma estúcia muito simple. E ensinou-lhe que tanto ou não tendo os cinqüenta anos justos, ele João Maçarico visse uma pataca de ovos (tempo em que os ovos custavam três por vintém!), batesse todos numa gamela, até levantar escumarada, depois chegasse de assento pra só sentir a bafage, e nada mais: com esta estúcia, dizia o caiuá, o homem mais cansado agüentava três viajadas por noite.

O João Maçarico comeu, que comeu carne de anta, de macaco e de onça, que afirmam serem todas de alta sustância: principalmente moqueava os bugios e os monos, e lambia os beiços, c'o petisco: demorou quarenta dias na expedição, matando jacutinga pros barreiros, que era uma barbaridade; (agora jacutinga é mesmo um pássaro bisonho, abobado, que se mata por brincadeira nesses caçadões da mataria); voltou remoçado, com sangue na guelra, viveza nas meninas dos olhos e firmeza nas juntas: e logo que se viu no retiro, a par c'o ribeirão da Canjarana, pertico de São Pedro, tratou de aprontar a receita do bugre do cinza.

Aquilo foi uma coisa em demasiado! O freguês ficou mais sacudido que um rapaz de espora curta, valente que até dava medo, comendo que nem tinha altura, trabalhando com uns talentos de espantar, uma maravilha! Todos os vizinhos reparavam na mudança, e paravam de boca aberta: um homem que andava percurando o chão pra se enterrar, de tanta fraqueza e desânimo, avivado e forte assim! 
Pois pra encurtar razões, entende-se c'os pais da Salustiana, uma china de espavento, e, preparados os papéis e feitos os pregões, casou-se um belo dia. A Salustiana era uma moça avariada, conforme rosnavam cartas línguas malinas da redondeza, e os pais alegraram-se por de mais, quando se descartaram dela: aquele marido pra filha caíra-lhes do céu! Depois, um cristão que não tinha boca pra ofender seu semelhante, com um gênio manso de verdade; era edadoso, isso era - mas o estrago que a noite tinha penderia por igual o lado duma balança, se fossem e peso as duas qualidades.

A princípio, muito que bem! Tudo ocorreu em santa paz, a gosto e prazimento de todos, até as Salustiana, que se espantava de ver um velho teso naquela proporção: parecia um mico, mal comparando. Mas o que é bom logo acaba, o João Maçarico desmereceu outra vez, perdendo as carnes e o brilho das meninas, cobrindo-se de pés-de-galinha mais fundos pelo rosto, uma tristura!

Trabalhava no ofício, não pôde mais suster-se pé em frente ao banco da carpintage, escolheu outra profissão, que foi a de lenhador. E daí em seguida varava quase que os dias inteiros na capoeirada, ou na mata-virge, aprontando os feixarrões de crindiúva ${ }^{54}$, ou de caiúia, ou de ceboleiro, ou de embira-de-sapo ${ }^{55}$ que levava de encomenda pras fazedeiras de sabão, por serem esses paus muito bons pra cinza de barrela; os manojos macotas de tapiá, de guapeva, de guamirim, de pindaíva ${ }^{56}$, pros fugões; as braçadas de varas de canjarana, ou toradas de coração-de-negro, de taiúva, de canelão, pras cercas: e ia ganhando a vida por essa forma.

\footnotetext{
${ }^{54}$ Nota da edição: Segundo FERREIRA, Aurélio Buarque de Holanda. Op. cit., p. 499 e 1427, crindiúva, do tupi karãd'üwa é um brasileirismo que significa o mesmo que quatindiba, que é uma alteração de corindiba, e é nas regiões leste e sul do Brasil uma "designação comum a plantas arbustivas e espinescentes, da família das ulmáceas, de flores apétalas, alvo-esverdeadas, dispostas em fascículosaxilares, cujos frutos são drupas pilosas e ásperas, e que fornecem madeira alva, fibrosa e flexível, com variado emprego na indústria; corindiúba, crindiúva".

${ }^{55}$ Nota da edição: Também segundo FERREIRA, Aurélio Buarque de Holanda. Op. cit., p. 631, o termo embira, do tupi ếbira, é um brasileirismo que se constitui em uma "designação comum a várias espécies arbustivas da família das timeleáceas e do gênero Daphnopsis, de flores inconspícuas, e que se caracterizam por produzir boa fibra na entrecasca. Ocorrem nas matas úmidas". Embira-de-sapo (que não consta em Ferreira, 1986) é, certamente, uma espécie de embira.

${ }^{56}$ Nota da edição: O vocabulário, ao final de Mucufos, informa que pindaíva é a mesma coisa que pindaíba. A respeito de pindaíba, diz SOUZA, Bernardino José de. Op. cit., p. 251: "no interessante volume de Hermano Ribeiro da Silva - Garimpos de Mato Grosso - encontramos duas vezes este vocabulário com significação regional: às págs. 115 e 260, respectivamente: 'Nas campinas, nos cerrados, ou nas esparsas nesgas de mato pindaíbas, que compõem a flora do planalto... (...) Instala-se o acampamento à vista de farfalhante buritizal que orla uma pindaíba (oásis de mato) existente nas cercanias do alto do despenhadeiro'. Neste sentido equivale provavelmente a capão".
} 
A Salustiana, de primeiro, não desgarrou, foi fiel pro seu marido, foi de todo o cuidado: mas uma china como a Salustiana, ché! Não pode deixar de não se esquecer das suas obrigações, dês que não tem amor ou não tem medo ao seu companheiro. E um dia... Nem foi um dia, foram logo uns par de dias duma vereda só, marcou lugar de encontro pro Zeca do Pica-pau, e enlouqueceu de tudo.

O Zeca do Pica-pau, passada a soneira do repente, largou dela; e a Salustiana arrecebeu o Manequinho, o Valentim, o Zé Ricardo, um dilúvio deles, um por um. Caiu, que foi um desespero! E o pobre coitado do João Maçarico estava só serenando na labuta se sol a sol, pra sustentar a malvada da sirigaita.

O rumor da senvergonheira foi bater até aos ouvidos de seo vigário. Seo vigário, um padre muito direito, não gostava que as ovelhas do seu rebanho (assim falava nas práticas do domingo) se perdessem que nem a Salustiana. Por isso, querendo sugigar o mal e prevenir o futuro, e encontrando-se uma vez com o João Maçarico, que vinha embodocado por debaixo dum mundão de coivaras, mandou que ele apinchasse pro chão a pausaria, e quis puxar com ele uma prosa por estas palavras:

- Ah! João Maçarico, como é então que você pode trabalhar agüentando tamanhas galharadas?

- Trabalho, seo padre, - respopndeu-lhe o outro: trabalho, e bem satisfeito da vida, com favor de Deus!

Seo vigário, que não calculava que um cristão não sabe de certos acontecimentos da casa, que certos acontecimentos correm sempre em segredo, saiu resmungando:

- Pois se é do seu gosto, arrume-se: o que é de gosto regala a vida.

E desapareceu na volta da rua que leva pra igreja, com as orelhas quentes e brabo, que ia tinindo! 


\section{$\underline{\text { Análise do conto }}$}

"João Maçarico" pertence ao grupo de contos em que existem muitos arcaísmos, entre os quais estão: "home”, "sojeito", "percisão" e "cobiçosa”. É quase todo narrado no falar caipira e apresenta poucos diálogos. Prende-se à fase experimental do autor, na qual ele associa o falar caipira ao caso, na esfera da ficção.

O conto possui um enredo simples e coloca de forma sintética a questão da quebra da moral vigente, por parte de um comportamento inusitado de um casal que despreza os ditames da moral católica. Além disso, focaliza o trabalho e as profissões. 


\section{$\underline{\text { Quebrante }}^{57} 58$}

Que vontade a Maria Peneireira não tinha de ter um filho! Vivia rezando pra São Bento não fazia conta dela, a mó’ que. Promessa e mais promessa, jejuns em louvor de quanto santo conhecia, resguardo e rejume louco, dava tudo em água de barrela, dizendo, verdade era que dentro de três anos nada tinha arranjarava. Andava caindo no desânimo, duma vez, quando, em razão duns barulhos caseiros, largou do Nastácio e foi campear a querência antiga, a casa dos pais.

Foi pouquinho, o tempo que passou na querência antiga. Pissuía um coração mole, enrabichou-se de repente por um tropeiro que navegava dos três ranchos pra cá e de cá pros três ranchos, por nome de Juquinha Hortênsio. Bateu as asas, um belo dia, e arranjaram o ninho ali pro Chico Marques, mais pra ali, mais pra além, por aí assim. Ê lá vida boa, a que eles gozaram! Só Deus c'os anjos poderão saborear uma vida semelhante!

As orações da Maria Peneireira na certeza tiveram mais favor, dês que ela pegou de amores c'o Juquinha Hortênsio: na certeza, porque, revirados poucos meses, ela pricinpiou a sentir enjôos de estômago, entojo por quanta coisa havia, tonturas e outros sinais de esperança; revirados mais uns dias, mais uns poucos de meses, deu de engordar à vista de todos; correram trinta dias por um mês, mais um, mais outro, e São Bento afinal teve compaixão da Maria, mandando-lhe um filho bonitinho que era ûa maravilha.

Aconteceu o que havia de acontecer: a criança foi levada à igreja, batizada por Bento, mas não chorou quando o padre lhe botou sal na boca. A mãe, que estava junto, sentiu um baque no coração, porque é ruim quando a que vai pra pia não estranha o amargo do sal. Mas o sacramento chegou ao fim, ela segurou o filhinho, beijou-o, beijou-o um dilúvio de vezes, e troteou pra casa, que não era tão nas vizinhanças, pois uma légua e um quarto não se vencem c'a ponta dos beiços. O menino, enrolado numa roupa muito linda e enfeitada de fitas de quase todas as cores, nem mexia, parecia ir dormindo.

Quando frontearam a venda que tem pro lado esquerdo, na encruzilhada, a irmã da Maria Peneireira, que estava ali se pouso, chamou-a, e desejou ver o nenê. A Maria bem quis

\footnotetext{
${ }^{57}$ Nota CLSD: "O Paiz. Rio de Janeiro, 27 ago., 1897. (Escrito em Sta.Cruz do Rio Pardo, em 1897)".

58 Nota da edição: O conto possui versões nas pastas Mucufos e Originaes manuscriptos de Papae (preciosíssimos).
} 
dizer: qual, Valência, é melhor deixar o coitado dormir seu sono sossegado -, mas não teve ânimo, e entregou-o dormindo à Valência. A outra desembrulhou o chale que o encobria, reparou firme no rosto mimoso, fez uma cara alegre e risonha, e disse:

- Ah! Que belezinha, Maria, que belezinha! Eu, se tivesse um capanga assim, até me contemplava a mais feliz de todas as mulheres! E tem um dormido tão mando! Ah! Que graça, que encanto!

Ora, quando a Maria Peneireira entrou em casa e foi pôr o pequetito na cama, o pequetito ficou co'a cabeça descaída pra um lado, amolengada e sem jeito. Ela cuidou que fosse o sono, arranjou o travesseirinho, amaciou a colcha, deitou-o: mas a cabeça pendeu pra uma banda, que nem um trapo meio pesado, os olhos entortaram-se, a boca franziou-se dum modo esquisito. E aí a pobre da mãe, desatinada, clamou a céus e terra que o Bento 'tava nas últimas, morre-não-morre, e que aquilo não passava de quebrante.

Por volta da meia-noite, mais ou menos, a criança fechou pra sempre os olhos, passando desta vida pra outra feito um cuitelinho. A Maria, a princípio, não sabia que pensamento havia de escolher, dentre tantos que lhe alvoroçavam o espírito aloucado de dor: mas quando, mas quando, tendo posto mais atenção no vulto do filho morto, viu ainda aquela triste cabeça como que desconjuntada, começou a chorar e saluçar alto, perdidamente.

Os galos já estavam violando, a noite era de lua. Ela conservara-se de pé junto da cama, tremendo como um ramo de folhas noviças, que o vento sacode, cada vez que os gemidos a queriam estrangular. Aí então afastou-se de soco, c'os cabelos arrepiados e um fogo temeroso nos olhos, gritando:

- Foi aquela desgraçada da Valência que botou quebrante no meu filho! Foi aquela bica à toa, aquela juruveva, aquela potranca danada! Mas há de me pagar, há de me pagar tamanha desventura que me dá.

Tomou o filho morto nas mãos, saiu pela estrada, sozinha, corre-que-corre. Ninguém pôde ter mão dela, a violência era de mais. Seguiram-na de longe. Assim que se aproximava da venda da encruzilhada, já ia aos brados chamando pela irmã:

- Ó Valência! Valência!

A Valência, acordada assim fora de horas, atemorizou-se, escondeu-se bem nas cobertas. Mas logo que reconheceu a voz da irmã, voz cortada de lágrimas, saltou da cama, pichou um chale na cabeça, rompeu na porta. 
A lua ia empalidecendo, queria enfiar a cabeça no seio da montanha mais alta que se via duas léguas em roda. E a Valência, vendo o jeito desmantelado da irmã, cujos peitos se levantavam e baixavam a todo instante como se fossem dois polmões que estivessem latejando, chegou pra perto dela. O Juquinha Hortênsio e as mais pessoas que tinham acompanhado ainda vinham a umas cem braças.

Neste artigo a Maria Peneireira, pondo com muito cuidado o filhinho em riba dum pranchão rente da casa, atirou-se à Valência, agarrando-a pelo pescoço, apertando-lh'o, c'umas unhas que pareciam tão afiadas como as do canguçu. E rugia, que rugia:

- Você deitou quebrante no meu filho, ordinária! Você botou quebrante no meu filho, lagacha!

A Valência debateu-se, sufocada, tremeu, estremeceu, endireitou-se toda, ficou depois toda convulsa, depois rija que era ver um defunto.

E assim que o Juquinha Hortênsio puxou a Maria, contendo-a pela força bruta, ela fez menção de ajoelhar-se, rogando:

- Pelo amor de Deus, deixe que eu mate aquela malfadada!

Arrastaram-na para longe. E de longe ela gritava ainda, até desaparecer na baixada do caminho:

- Ah! Piguancha sem sangue, você botou quebrante no meu filho! 


\section{Análise do conto}

"Quebrante", assim como "Amaldiçoada" e "Pazes", é um bom exemplo de texto onde a convivência narrador/ personagem foi satisfatoriamente resolvida, em termos de adequação do discurso. Ambas as falas (do narrador e das personagens) se aproximam bastante, pois são praticamente elaboradas no falar caipira, marcado pelos regionalismos e arcaísmos. Um bom exemplo são os trechos abaixo:

\footnotetext{
"Que vontade a Maria Peneireira não tinha de ter um filho! Vivia rezando pra São Bento, a bem dizer dia e noite, e São Bento não fazia conta dela, a mó’ que. Promessa e mais promessa, jejuns em louvor de quanto santo conhecia, resguardo e rejume ouço, dava tudo em água de barrela, dizendo mal. Fosse por culpa dela, ou do Nastácio, com quem morava, verdade era que dentro de três anos nada tinha arranjado. Andava caindo no desânimo, duma vez, quando, em rezão duns barulhos caseiros, largou do Nastácio e foi campear a querência antiga, a casa dos pais."
}

(...)

"Neste artigo a Maria Peneireira, pondo com muito cuidado o filhinho em riba dum pranchão rente da casa, atirou-se à Valência, agarrando-a pelo pescoço, apertando-lh'o, c'umas unhas que pareciam tão afiadas como as do canguçu. E rugia, que rugia:

- Você deitou quebrante no meu filho, ordinária! Você botou quebrante no meu filho, lagacha!

O narrador, na passagem acima, usa expressões típicas do coloquialismo sertanejo, tais como "Neste artigo", "pondo com muito cuidado o filhinho em riba dum pranchão" e "rugia, que rugia". Isto confere uma maior naturalidade e realismo à narrativa. 
O Neco da Prata botou a viola na peitaria e cantou a primeira moda da função. Povo ficou de boca aberta, em roda dele, admirado. A parceirama estava que nem mexia, com gosto de escuitar a voz desse peito limpo assim. E como não tinha a mais pequena arage nessa hora, e a animalada não fazia rumor de qualidade alguma, a pelenga ia morrer nas beirinhas do ribeirão, enternecida de tudo:

‘Todo’ os passos cantam bem
não cantam como a sabiá.

Chó! chó! passarinho, chó! chó! sabiá:

que eu canto

pra não chorar."

Só isso, mais nada, mas porém toado dûa maneira que só mesmo o Neco seria capaz de arranjar. O pinho, então, quando era pra acabar o verso, a mó’ que gemia que nem um cristão amaguado. As mulheres escorrupichadas pelos cantos da sala, na escada, na cozinha, tinham fechado a boca por milagre, falando mal e descortesmente: e punham cada olhos no folgazão que a gente não sabe como não o espatifavam! A candeia de azeite, pendurada num mancebo pra uma banda, perto da porta do terreiro, alumiava pouco, já dava uma luz murcha e tremida, sinal que estava desdeixada: o tempo não chegava pra se ouvir e aprender a moda nova daquele cantador tão cuera.

Assim que o Neco rasgou duma vez o pinho arrematando a cantoria, houve um reboliço, um terramote na casa. Aí que lembraram da vida, que cuidaram na festa, nas lamparinas, na ceia. O dono da casa, um home de muitos anos, pombo devera, seo Romualdo, saiu do catira e foi lidar c'os trens de comer: e quem reparasse nele havia de ver que dois pingos d'água lhe paravam um numa ponta, outro noutra do bigode. Coisa que de vez em

\footnotetext{
${ }^{59}$ Nota CLSD: "O Paiz. Rio de Janeiro, 8 maio, 1898. (Escrito em Sta. Cruz do Rio Pardo, em 1897)".

60 Nota da edição: O conto possui versões nas pastas Mucufos e Originaes manuscriptos de Papae (preciosíssimos).
} 
quando sucede: uma pessoa edadosa recordar-se do que passou, por ouvir um toquinho qualquer, e chorar de saudade.

Seo Romualdo tinha feito uma reza, promessa antiga a santa cruz, e depois da reza deu essa festa: toda a rapaziada da figueira e do dourado se reunira, os velhos também apareceram, e a gente ficou empinhocada no terreiro, perto da cruz. Capelão, foi o Zé Domingue, que tem um tino onça pra estas cerimônias e conhece rezas como ninguém. Logo que acabou a devoção, disperaram um dilúvio de salvas de garrucha. Nesse instante, nem mais e nem menos, levantou-se lá no cocuruto daquele morro a cara da lua, uma lua cor de sangue, muito esquisita, que depois foi ficando cor de rosa e afinal embarqueceu, que foi uma boniteza.

Êta! Caipirada do matão! Vocês são mesmo de virar e romper pra um divertimento! Seo Romualdo, que se pela por uma pândega dessas, ria-se a toda hora, alegre por ver os convidados alegres, entusiasmado c'a disposição dos mais. Subiu uns três palmos arriba do chão, c'a moda do Neco da Prata, porque de uns par de meses pra cá não se conheceu lindeza tamanha, nos pagodes da fazenda e dos arredores. E pegou a remorder a toada, indo e vindo de um lado pra outro, na cozinha, atabulando a ceia, caceteando a companheira, nhá Tereza, que não sabia o que fazer, de tão azoretada.

Enquanto se arranjavam os perparos da mesa, o Neco da Prata, que não quis mais ficar na roda p'r amór de a laranjada que estava arrebentando, encostou-se no cocão dum carro que se via pegado c'a porta, puxou sua faquinha da cinta, alisou uma palha, trouxe um coto de fumo da 'gibeira, picou, que picou, e deu por pronto um cigarro. Ia tirar fogo da binga, já apertava a pedra nos dados da mão esquerda, em cima da estopa, e o fuzil na direita, quando sentiu um vulto mesmo rente consigo, parecido uma visão. A primeira coisa que fez foi estremecer um bocado; mas, da vereda que estremecia, pressentiu um chamado cochichado, depois dum aceno ligeiro c'um lenço. Caminhou na linha do aceno e topou peito a peito c'a Maria do Viriato.

Aquele corpo da Maria, tão cubiçado, de tanto tempo, foi ver o calor de uma fogueira, pro Neco, deixou-o bambo, bambo. Ela então ia-lhe explicando que agora estava às ordes dele, afinal chegara o dia que ele desejava com tamanhas paixões e que ela esperava com toda a vontade, mas porém com tamanho medo! Porque o Neco bem sabia (continuava a morena) que o Viriato era um tigre, de zangado: por qualquer miuçalha de nada armava um barulhão temeroso, quanto mais se percebesse a enleada! O Neco, aí, pôs-lhe as mãos nos 
ombros e pegou a contemplar os olhos tão pretos que foram a perdição e o desespero da sua vida, esses meses pra trás: e como a lua ajudasse, passada pelos vãos de uma arve-de-lagarto debaixo da qual proseavam, ele podia reparar que os beiços dela tremiam que nem os de quem está com febre assezoada.

Proseavam longe da casa umas dez braças, pra uma banda do paiol, e só mesmo quem fosse muito desconfiado ou muito especula era capaz de calcular que os dois se reuniram tão vizinho c'a festa. O Neco percurava assossegar a amante, mas qual! A Maria era só aquela tremedeira! Por último, vendo que ela estava assustada e medrosa de mais, ele pregou-lhe um pito acochado:

- Ah! Nhá Maria! Então é assim que vancê me quer bem? Pois se me estima de verdade, escusa de 'tar que nem uma varinha de taquari, bule-bulinho p'r amór de o vento. Quem tem amor, não deve pensar no perigo. Vancê nunca ouviu dizer que, quanto mais perigoso, mais gostoso? Olhe, nhá Maria: não se atemorize à toa. Lembre-se do verso que fala: um home nasceu pra outro, a sorte Deus é quem dá. Nhô Viriato...

Neste repente houve um reboliço macota na sala do fandango. A moça, nem bem lhe bateu nos ouvidos semelhante guaiú ${ }^{61}$, correu pra dentro, esquipado e violento como uma veadinha. O Neco teve tempo só de recambiar o corpo e sumir numa touceira anexa à arve junto de que se achava: e saiu um pelote de gente pro terreiro, fazendo uma gritaria que não tinha mais jeito.

Era uma briga séria. O Viriato, que já andava político, de dias, c’um tal Serrador, passou beirando co'ele e puxou pigarro da goela. O Serrador não gostou da leréia, disse-lhe uma liberdade, o Viriato rebateu-lhe com outra, e a coisada principiou braba de tudo. Num momento tiveram que romper pra fora, porque a caboclada enrolou-se co'eles num pacote, e abriu.

No terreiro, a fúria aumentou que foi uma disparidade! O Serrador, que era senhor dûas mãos deste porte e duma destreza perigosa, deu logo de dançar e corcovear perto do

\footnotetext{
${ }^{61}$ Nota da edição: Segundo SOUZA, Bernardino José de. Op. cit., p. 302, sujo é uma "designação regional mineira, dada a certa formação florística: é a vegetação que sobrevém, de pronto, à derrubada de uma floresta primária ou secundária. (Contribuição ao Estudo da Flora Brasileira por Honório Monteiro Filho; Boletim do Ministério da Agricultura, julho-setembro - 1934)".
} 
outro, feito um tamanduá-bandeira no sujo ${ }^{62}$. E o Viriato, que já se via ocasionado duma vez, corria em riba dele, virava, que virava, c'um refe na mão direita, mas em pura perda de tempo, que o Serrador era mesmo ventana, ver uma cobra.

Mas porém houve uma hora tirana: o Viriato, com certa manha e tramóia, foi levando o Serrador até junto do carro, que estava entestado c'a parede da casa, encurralou-o a conta inteira... E ia passar-lhe o refe, sem apelo nem agravo, pois o Serrador tinha só destreza e no mais era um perrengue, magricela e franzino, quando o Neco da Prata pulou no meio da história, falando acelerado:

- Ora já se viu que desmancho sem propósito! Vocês vêm pra festa de seo Romualdo e armam um banzé deste feitio? Quem quer rixa escora o parceiro na estrada, não é na casa dos mais, principalmente se está de favor, como agora. Larguem mão disso, é melhor!

O Viriato buzinou, que foi uma tristeza. Disse as do cabo pro Neco, arreliou-se em demasiado. E o Neco, assim que não pôde mais, assim que viu que nem um companheiro lhe assistia, apaziguando o brigador, não teve remédio senão recuar dois passos pra trás, segurar um fueiro do carro e descê-lo com vontade nas munhecas do Viriato: uma das pauladas acertou-lhe no chato da cabeça, e o Viriato caiu redondo no chão, feito um macuco, apesar que inda revolvia o refe pro ar.

Tudo ficou ali num silêncio que dava altura de se ouvir ûa mosca. Mal apena o ofendido gemia um pouco; pra mais longe, sim, os animais disparavam, relinchando, espaventados. Foi preciso que o próprio Neco falasse:

- Home, vocês não serviram pra apartar as dúvidas, sirvam ao menos pra me prender, que eu 'tou na alçada da justiça, reconheço.

E os moleirões dos fandanguistas, corridos, envergonhados, chegaram pra perto dele, passaram-lhe uma corda nos braços, amarraram-no, imediato, no tronco da mesma árve-delagarto à sombra da qual ele tinha conversado, fazia poucas horas, c'a Maria, a sua tão querida, tão desejada Maria, que agora o olhava da porta, co'a suspiração tomada, quase louca.

Trataram de levar o preso no sofragante. Ele perpassou pela Maria, deu-lhe adeus:

\footnotetext{
${ }^{62}$ Nota da edição: Segundo SOUZA, Bernardino José de. Op. cit., p. 302, sujo é uma "designação regional mineira, dada a certa formação florística: é a vegetação que sobrevém, de pronto, à derrubada de uma floresta primária ou secundária. (Contribuição ao Estudo da Flora Brasileira por Honório Monteiro Filho; Boletim do Ministério da Agricultura, julho-setembro - 1934)".
} 
- Adeus , nhá Maria, vancê me desculpe, sim?

A Maria sentiu um nó na garganta, não pôde arresponder-lhe.

Ele falou mais baixico, assim meio resmungado:

- Nhá Maria, pode-me esperar, que eu faço logo a minha livração e volto. O caboclo morre, não tem como não morra. E eu escolhi uma casião muito boa, vancê bem viu...

Depois, quando a comitiva garrou chão, ele foi cantando, cantando, até desaparecer na dobra do morro. Dobraram o morro, e a Maria ainda escuitou, muito tempo, o finzinho da moda:

\author{
"que eu canto \\ pra não chorar."
}




\section{Análise do conto}

"Ânsia antiga" está no grupo dos contos que apresentam bastantes arcaísmos. Não se constitui em um texto longo; apresenta poucos diálogos e trata do tema da violência. Em uma certa "função", acontece uma "briga séria" de Viriato com Serrador e acaba envolvendo outros caboclos. No final, um deles, Neco, se interpõe entre os dois brigões, mas na ânsia de conter Viriato, dá-lhe uma paulada na cabeça, matando-o. O conto termina com a prisão de Neco; aliás é ele mesmo que se entrega aos "fandanguistas", sendo levado à delegacia. No caminho, ele canta trecho de uma moda para sua amada Maria (a mulher de Viriato), dando outro viés à narrativa e surpreendendo o leitor.

Alguns dos arcaísmos presentes no conto são: "escuitar", "arage”, "passos" (com o sentido de pássaros), "amaguado", "terramote" e "cubiçado". 
Assim que apareceu no povoado a Chiquinha Araçá, vinda lá desses recantos do sertão do Panema, e que foi assistir nûa meiágua estrangolada ali beirando o rio, sinh'Ana do Ozébio não se conteve, de tanta ira, e saiu dizendo pra quanto vizinho havia que aquilo era uma pouca vergonha, uma coisa sem pé nem cabeça, um desperpósito. Onde é que já se viu agora ûa sojeita da vida vir morar no meio das famílias, bem concha c'o seu galheiro, como se tudo fosse muito direito? Aquilo não podia continuar!

Sinh'Ana, desde pequetita, segundo todo o povo falava, fora uma soberbona de marca maior. Filha dum pai que tinha de seu fazendas e mais fazendas, culturas, criações em demasiado, não percurava as pobres, na escola, e só fazia companhia c'as das mesmas posses que ela; filha dûa mãe bonita e de bem que nem uma santa: falando mal, não era capaz de se avir c'as meninas que não tinham pais conhecidos à vista da santa igreja. De sorte que andava quase sozinha, repimpada nos seus vestidos cheios de folhos e rendas, alegre dos seus babadouros largos, de cambraia, e dos pentes de tartaruga que fincava nos cabelos.

Depois, em casando, a mó' que ficou mais pior ainda, assim diziam nos arredores: então só se agradava das mulheres que tinham marido legítimo e eram ricaças ou remediadas; as outras, essas vivessem lá como a Deus fosse servido. Agora o que é verdade é que ninguém nunca não teve corage de romper duma vez c'a sinh'Ana: parece que a riqueza dos outros entope a boca dos pobres, e nem uma neta de Eva não disse em tempo algum liberdades a tão malvada criatura. Sinh'Ana mandava seis meses no bairro, principalmente na gente de saia.

Ora a Chiquinha Araçá, morena bem sossegada, afinal, que teve por sina cair como tantas outras, a princípio não botava atenção em nada, nem em ninguém dos arredores; mais tarde reparou que aquela dona, cada vez que a via, fechava carranca, saía da porta ou da janela, batendo-a com fúria, e, se estava na rua, virava-lhe as costas no mesmo instante; pensou de si consigo que decerto já as línguas enredeiras tinham aprontado alguma, e deu tempo ao tempo. Contou o causo ao galheiro, um tal Zé Benedito, e o galheiro arrespondeu-

\footnotetext{
${ }^{63}$ Nota CLSD: "O Paiz. Rio de Janeiro, 8 maio, 1898. (Escrito em Sta. Cruz do Rio Pardo, em 1897)".

64 Nota da edição: O conto possui versões nas pastas Mucufos e Originaes manuscriptos de Papae (preciosíssimos).
} 
lhe que não se importasse, porque, quando fossem pôr o feijão no fogo, não haviam de o pedir à dita dona. E ficou tudo nisto.

Paulista desempenado era o Zé Benedito, ê lá paulista! Por seu respeito um dilúvio de raparigas andavam de coração sangrando, aí nesse mundo louco donde eles vieram; uns tempos ele foi o susto das casas sérias, transtornando o sossego de muita rolinha solteira, e causando o desespero de muitos casais; viveu mexe-mexendo pelas capelas, anos e anos, e aprendeu uma pelintrage que bulia c'o sentido das tais, fazendo-as enlouquecer de tudo: arrodeava uma delas, arrastava a asa, chegava... E logo sumia pros braços de outra, voluve que nem uma borboleta. Mas garrou rabicho de couro cru pela Chiquinha Araçá, viúva novica que morava de favor duns tios, conduziu co'ela pro Salto, num batelão, e veio pra esta terrinha do Andrade: e daí pra cá o Zé Benedito ficou outro, bem se via.

Pegou logo c'a santa vida daquelas furnas lá de longe. Como violeiro, Jesus! - era cumba; cantava cada verso tão bonito, pra encarrear as modas, que até o povo que escutava era só pedir, pedir pra ele cantar mais um, mais um; quando rompia daquela garganta ûa pelenga das que ele usava, bem toada, bem afinada como ele sabia, as pedras eram capazes de arrebentar, principalmente pelo amanhecer. Assim falavam todos os fandangueiros daquelas furnas: e em santa cruz a mesma fama cresceu depressa, aumentou, pra dizer mal, que nem as pragas em pasto praguejado.

Mandou o Delfino do Ribeirão fazer-lhe uma viola de pinho; e se bem mandou, melhor o Delfino fez: cada hora que o Zé Benedito rasgava o pinho, dum jeito novo que ninguém não tinha visto ainda, um meio arrepio passava p'lo corpo de quem estava perto. Depois, pra pontear uma dança qualquer, pra tocar uma quadrilha ou a valsa-viana, andava sozinho. Gente principiou a descer da serra pra ver o violeiro descanhotado que fazia o que queria do instrumento.

A Chiquinha, então, sentia-se alegre deveras, por ver que o tafulo ganhava rumo na praça: porque a melhor maneira de se começar direito um negócio é agradar bem primeiro o freguês: e quando ele quisesse meter cara nessas invernadas, comprar seus bois magros pra engorda e venda mais tarde, barganhar seus caracus gigantes c'uns par desses chinas do córte, havia de encontrar simpatia por toda a parte. (Chiquinha Araçá, você tinha proporção de uma pura mulher: foi uma desgraça você desgarrar assim sem mais nem menos! Agora...)

Só o que não dava certo era o semblante sempre fechado da sinh'Ana do Ozébio. Um dia que se encontraram por acaso no cochicholo dûa mulher chamada a Mineira, pertico 
mesmo do rio, sinh'Ana afastou-se pra dentro do quarto da dona, fazendo o sinal da cruz; outra vez que a Chiquinha topou co' ela no porto em que lavava roupa, a sinh'Ana escondeu o rosto num lenço de cabeça, e saiu ventando por ali fora; ultimamente, na reza dum tal Bonifácio, lá d'outra banda, a sinh'Ana deu adeus pra todos que se achavam na sala, e, passando pela Chiquinha, virou o frontispício e não lhe estendeu amão.

Valeu isso botar-se a pobre da moça pra casa, já no meio da noite denegrida, atirar-se a um catre e prantear que nem uma demente. Fazia exclamação que Deus devia tê-la matado no instante em que aconteceu pra ela tamanha infelicidade, que as outras viviam na satisfação de todos e que ela, a bem dizer, andava escorraçada. E como Zé Benedito entrasse nesta intendência e pusesse atenção naquelas lástimas, respondeu-lhe por estas palavras:

- Ora, Chiquinha, isso não paga a pena! Pois p'r amór de a sinh’ Ana do Ozébio você toma tamanha tristeza? Olhe que ela nem merece essas lamúrias! Você vai conhecer que relé de gente 'tá ali: espere pela pancada. No frigir dos ovos é que se vê a manteiga que sobra.

A Chiquinha araçá achou-se mais consolada. Foi-se repondo, pouco a pouco, e ficou tudo nisto.

Não há nada mais certo: quem fala, paga. Outros proseiam que pela boca morre o peixe. O que é mesmo verdade é que ninguém deve dizer: desta água não beberei.

O Ozébio, que tinha umas terras na fazenda de São Domingos, a tal que verte pro rio Pardo, compra antiga que fez dum fulano Esaú, arrasara mato, nessas eras pra trás, fizera cada derrubada e tanto, plantara cada roça de encher os olhos. Nunca lhe faltara milho num paiol de cinqüenta carros, por derradeiro foi preciso até fazer um puxado no dito paiol, pra dar cabida a mais uns trinta; arroz, era um despotismo; feijão, ché! Ninguém colhia a quarta parte do que ele colhia; abobras; pepinos, maxixes, jacutupé, tudo se via com abondância naquela casa: e a pinga de vinte graus que fabricava, sempre firme e de boa fama, varava ano e mais ano, a mó' que sem acabar nunca. Fartura semelhante, é coisa por demais!

Mas a resto veio a medição da fazenda. Os homes que requereram a divisa reviraram quanto cartório havia por aí fora, por Lançóis, Itapetininga, Santa Bárbara e Botucatu, e os papéis da gente conhecida pelo nome de Esaú ficaram não valendo nada. Houve réiva, quase saiu pancadas e morte, e quem ficou devera na derrama foi o pobre do Ozébio, sem um palmo de chão de seu. Nem bem soube que o negócio estava desse feitio, tão mal parado, o Ozébio 
esfregou as mãos na cabeça, c'um desespero de mantecato, e disse que ou havia de passar uma chumbada no Baltazar e no Chico Gracía que chamaram a divisa da fazenda, ou morria sem apelo nem agravo.

Não aconteceu tão depressa, mas aconteceu o que ele porferiu. O Ozébio o que sim fez foi desmerecer de repente; ficou logo nas espinhas, de magro, e banzativo e soronga que dava que pensar. Saiu dia, voltou dia, até que chegou o último daquele filho de Deus; contam que morreu de mal de engasgo, mas qual! Foi tristura, desânimo, falta de confiança nos braços e na cachola. Na madrugada em que esticou os cambitos, o miserave inda resmungava, por jeito que todo povo que o arrodeava escuitou: que assim ficava melhor, sumir-se duma vez deste mundo, pra não agüentar mais o peso de tamanha desgraceira.

Sinh'Ana, pra dizer que pranteou em demasiado, isso não: choramingou seu pouco, enxugou suas lágrimas pra um canto, fez por consolar-se, que enfim o que está feito já não está por fazer. E na missa do sétimo dia levou um senhor vestido de seda cheio de histórias, e um crepe na cabeça que mais parecia esses veuzinhos de luxo das moças. É pra mecês verem o quanto vale a firmeza de certas mulheres!

Quando chegou o tempo de aliviar o luto, já a sinh'Ana estava aliviada de tudo, no coração: deu de usar uns vestidos maneiros, brancos e só c'uns respingos pretos, umas saias escuras e uns casaquinhos cor de pomba de casa, pegou a ficar numa ponta que até era de pôr a gente admirada. Povo garrou logo a dizer que a sinh'Ana estava atirando o anzol pra algum frango novo, senão não havia de andar assim nos trinques, entusiasmada, sem nem um restico de tristeza nos olhos e na fisiolomia.

Voz do povo é voz de Deus. A sinh'Ana refiava um Jerominho lá do dourado, paranista cheio de cheio de não-me-toques, enjoado numa combersa e namorador por devoção antiga. Ele, então, quanto mais corda ela dava, mais corda ele puxava. Vinha todo domingo passear aqui na vila, montado num macho ruço que era um mundo: e se ele Jerominho era contador de histórias duma vez, o macho não ficava atrás, tinha um passo esquipado dos dianhos, e alevantava as mãos no lançante a desmunhecar-se.

Primeiro foi namoro direito, com todo o juízo: pro paranista era só aquela soneira, e pra sinh'Ana a mesma coisa. Mas o inimigo intreverou-se no meio, tentou a sinh'Ana, até que ela não teve como não acreditar nas patacuadas que o Jerominho lhe contava, e fez-lhe uns adiantados por conta do casamento, que havia de vir logo que ele preparasse os dicumentos percisos. Foi uma regalia! Ele gozava que gozava, ela gozava, que gozava - e o mundo 
principiou a treler c'o negócio, que se via atrasado. Umas pessoas chegaram a dizer pra sinh'Ana:

- Olhe, criatura: casamento demorado é desmanchado.

A sinh'Ana a mó' que nem vivia na terra, nem deu fé.

Passaram-se uns par de meses. Um dia, sem mais aquelas, o Jerominho abriu o pala, cortou chão; sumiu, ver uma onça espaventada, pra esses fundos de sertão de Mato Grosso, ninguém lhe pôs mais a vista em riba.

A sinh'Ana chorou, que foi uma lástima. Depois consolou-se, tal e qual como quando o Ozébio morreu. Ora, se o que está feito não está por fazer! E ficou tudo nisto.

No dia em que a sinh'Ana estava c'as dores, fazendo uma gritaria angustiada (porque afinal o presente que o Jerominho lhe deixou foi uma esperança, nada mais), nesse dia a Chiquinha Araçá, vestindo-se c'o vestido mais ventena que pissuía, entrou-lhe pela porta a dentro, sem mais nem menos, foi até o quarto onde ela gemia, que causava piedade, e faloulhe por este jeito:

- Sinh'Ana, agora que nós semos iguais de verdade, se mecê não tem mais soberbia, eu posso vir assistir-lhe, com todo o gosto. Mecê sabe que a gente vive na terra é pra ajudar seu semelhante.

A sinh'Ana não disse sim nem não: já estava c'a dormideira, mal ouviu aquela voz que parecia vir de muito longe, apagada e mansinha, e, quando voltou em si, foi pra pedir à outra ûa mão naquela hora apertada. A Chiquinha encostou-se-lhe às costas, segurando-a por debaixo dos braços, depois de a ter feito sentar numa quarta, e deu de contar-lhe histórias engraçadas, pilhérias de fazer rir, um passatempo e um consolo. Uma hora que lhe estava repetindo a passage que aconteceu c'o Teodorinho, quando foi camarada do padre Aranha, num ajutório tirano pra certo carreiro que 'tava c'o carro atolado na Água Espraiada, a sinh'Ana riu que foi uma coisa de espantar, no meio mesmo das dores, e a criança nasceu como por encanto, botando a boca no mundo.

A Chiquinha continuou a fazer-lhe animação:

- Pois assim é que 'tá direito e que 'tá bom. Onde é que já se viu uma dona como mecê, forte e sacudida, querendo entregar agora a rapadura c'a palha e tudo? Isso inté nem tinha cabimento! 
Mas a sinh' Ana descaíra pra uma banda, meio desmaiada, c'os olhos afundando e um suspiro saindo de lá bem de longe, puxado de vargazinho e fracamente: foi perciso mandar aquentar-lhe uma pinga, e a Chiquinha, depois de bebida a pinga, ainda caçoou c'a doente:

- Ué, sinh'Ana, é agora que amarela então a sola do pé? Largue mão disso, crie corage: repare nesse boizão do seu filho e veja que ele já 'tá com fome! Repare só!

Pouco a pouco, assim como quem vem cansado, duma viagem cangotuda, a sinh'Ana foi abrindo os olhos, ficando outra vez co'as cores, e quase que chegou a rir. Mas o outro não nascia, a Chiquinha tomou-a outra vez pelos braços, mandou que ela fizesse força e rezasse três vezes a oração de Santa Margarida, que é a última pra esta necessidade:

- Santa Margarida... Santa Margarida... Santa Margarida...

A sinh'Ana mal chegou a rezar a terceira vez. Estava livre. Olhou em roda de si, não viu mais ninguém que não fosse a Chiquinha Araçá, teve uma saudade do tempo em que vivia cercada de flor do povo, uma gana louca do Jerominho, e principiou a chorar baixico e sem falar nada.

A Chiquinha, depois que arranjou a cama, os travesseiros, e pôs a criança em riba dûa almofadinha, perguntou serena e sossegada:

- Antão, sinh'Ana, a gente se ajeita bem é mesmo c'os pobres e c'as mulheres que vevem na tafularia, não é?

E foi-se embora. Quando já tinha desaparecido, quando o som dos passos já morrera na volta duma esquina, a sinh'Ana, pegando o filho e abraçando-o, falou consigo mesmo, tal qual quem fala com alguém:

- Mas porém não sou da sua relé, saracutinga! Ao menos inda tenho esta criança, coisa que você nunca teve e nunca mais há de ter na terra, mulherzinha rebelde! 


\section{Análise do conto}

"Soberbia" é um conto que recompõe alguns aspectos da realidade sócio-econômica rural do final do século xix. Esses aspectos "ligam-se à natureza da relação homem do campo/trabalho/disponibilidade de terras", segundo Carmen Lydia de Souza Dias ${ }^{65}$.

Aborda a educação decalcada no preconceito de classe em uma mulher da alta sociedade rural (Sinh'Ana do Ozébio), que fora criada separada das meninas mais pobres.

Os aspectos da realidade sócio-econômica rural do final do século xix, referidos anteriormente, referem-se à natureza da relação homem do campo com o trabalho e à questão da posse e da disponibilidade de terras. Através da caracterização de Sinh'Ana do Ozébio, o narrador-autor revela alguns motivos importantes que constituem a luta de classes no ambiente rural. Um deles é a discriminação do mais pobre por parte do mais rico. Essa discriminação aparece por meio do viés religioso, que marca fundamente moral da sociedade rural do fim do século xix. Podemos observar a discriminação na passagem abaixo:

“(...); filha dûa mãe bonita e de bem que nem uma santa, falando mal, não era capaz de se avir c'as meninas que não tinham pais conhecidos à vista da santa igreja”.

Um outro motivo revelador da luta de classes é o isolamento. Por não ser capaz "de se avir" com as meninas cujos pais não tinham nenhuma ligação com a igreja católica, Sinh'Ana optou por ficar apartada da comunidade rural mais pobre:

"De sorte que andava quase sozinha, repimpada nos seus vestidos cheios de folhos e rendas, alegre dos seus babadouros largos, de cambraia, e dos pentes de tartaruga que fincava nos cabelos”.

"Soberbia" está entre os 13 contos recheados de arcaísmos, como: "nûa", "meiágua", "estrangolada", "desperpósito" e "sojeita".

\footnotetext{
${ }^{65}$ DIAS, Carmen Lydia de Souza. Paixão de raiz: Valdomiro Silveira e o regionalismo. São Paulo: Ática, 1984. p. 40 .
} 


\section{$\underline{\text { Soneira brava }}^{66} 67$}

A Lidubina abriu um chale no ombro, pegou o chapéu de sol, um que é cor de rosa e tem rendas nas pontas, e saiu. Ventava por demais, porque vinha chegando mesmo o tempo dos frios. A Lidubina, toda receosa e vergonhosa, ora punha o chapéu de sol por diante, ora segurava co'as duas mãos os lados da saia: nesses momentos o chale dava de cair, e ela não sabia ao certo se havia de atender ao chale ou à saia.

Era hora de jantar de cedo. Adonde então se atirava tão linda criatura? Adonde! Pois adonde podia ser? Lá pros lados das pedras, por ter notícia que seu galheiro, o Nicolau das Brotas, andava fazendo pé de alferes a uma tal abobrinha, rapariga de compridas histórias que estava na ponta, por ser nova e conhecer feitiçarias, segundo metade do povo afiançava. A Lidubina era moça do Nicolau, toda a gente não desconhecia: como então o Nicolau tinha corage de fazer uma beleza assim de chá de canela?

Levava pressa, ia quase correndo. A umas par de mulheres que encontrava na rua e lhe davam adeus, só respondia à saudação e pedia pelo amor de Deus que não a estrovassem, que não a estrovassem. As mulheres ficavam c'a pedra no sapato, pois bicho pra ter curiosiadade como mulher até não há na terra -, e principiavam a reparar no rumo que a Lidubina tomava. E de pouco em pouco foi-se engrossando o terno das tais, até o ponto de serem umas quinze, que também ganhavam a direção das pedras.

A viage era curta, a Lidubina chegou logo. Fez chão na linha da mandingueira. A chamada Abobrinha morava no alto, na última casa, onde esteve, não faz muito tempo, a Cesara. Era dia de domingo, e o povo estava duro pelo caminho. A Lidubina não punha atenção no povo, nem olhava pra trás: ia só c'os olhos acesos naquela casa amaldiçoada. Foi chegar, meu dito, meu feito! - e ver já o Nicolau sentado num tamborete a par c’a tiriba, numa prosa cerrada.

A Lidubina apareceu à porta, salvou a todos, com toda a cortesia, porque ela é mesmo ûa morena de sola e vira pra essas coisas, e pediu um particular ao Nicolau. O Nicolau não tinha altura, de tão passado; não achou resposta pra dar à companheira: só sim saiu pra

\footnotetext{
${ }^{66}$ Nota CLSD: “O Estado de S. Paulo. São Paulo, 19 jan., 1902. (Escrito em Sta. Cruz do Rio Pardo, em 1897)”.

67 Nota da edição: O conto possui versões nas pastas Mucufos e Originaes manuscriptos de Papae (preciosíssimos).
} 
um lado, conversou lá suas conversas c'a Lidubina, e voltou pra campear o chapéu na varanda. Trouxe o chapéu, despidiu-se dos mais, e garrou estrada junto c'a Lidubina. A Abobrinha nem piou.

Quando chegaram ao rancho, a Lidubina falou estas poucas palavras ao Nicolau:

- Nicolau, você teve muita moda pra me seduzir e me deixar neste estado; agora esquece de mim p'r amór de as outras... Apesar de tudo eu não me queixo: se eu tivesse cabeça, não tinha largado meus parentes por seu respeito. E agora, que vejo que você não soube reconhecer o que eu fiz, vou-me embora, mas porém não quero sair escondida e fugida como saí da casa da minha gente.

Como o chale se lhe via mesmo no ombro, afastou-se, depois de encostar à parede da frente o chapéu de sol, que era um presente do Nicolau. Afastou-se, afastou-se, desapareceu na volta da rua.

O Nicolau das brotas murchou de repente: ficou, mal comparando, que nem boi alongado no ermo, assim que o sol vai entrando.

É de rezão falarem que a gente só sabe o bem que possui, depois que o perde: o Nicolau não gostou nem um pouco daquele abandono. Espairecia a princípio, rindo e folgando co'a Abobrinha, que era uma formiga saracutinga, de tão alegre e buliçosa; divertia-se, aos domingos e dias santos, em ir a um pavoeiro na mata do Bernardino, escuitando a berraria dos pavões e espichando-lhes fumaça, a todo o risco; trabalhador como sempre foi, de dia andava esquecido no serviço de oficina de carpinteiro, e estava tudo direito: mas assim que a barra do dia começava a sumir no encontro do céu co'a cabeça dos espigões, o pobre vinha sentar-se à porta da casa, matutando nas suas tristuras, encarangado como se sofresse grande frio.

Já se ia arrependendo das asneiras que tinha feito p'r amór de a Abobrinha: um homem que tem sua companhia e sente sangue aqui, não se enleva sem mais aquela c'uma ventena do facho. Mas bem se diz que se eu soubesse sempre anda atrás: agora, que a Lidubina cansara de aturar semelhante traidoria e o deixara duma vez, pegou às voltas c'o remorso. Remorso fora do tempo, vindo tarde e a más horas, que só lhe servia pra aumentar mais a dor da separação.

Largou a abobrinha de cabo a rasto: arre! Que pra fazer figura triste não é que um filho de Deus vem ao mundo! Largou-a, fechou-se consigo mesmo, não campeou mais 
conversa nem treta com pessoa alguma, senão pra receber ou entregar qualquer serviço, agarrou-se c'o Jesus Menino e c'a Virge Maria, dos quais era muito devoto, rogando-lhes, de quanto jeito havia, fizessem que a Lidubina voltasse. Mal e mal, sempre escrevia coisinha: rabiscou umas orações esquisitas, que aprendera com seu Galdino, por esta maneira: - Senhor Jesus Menino, determinai que aquela ingrata volte pra minha companhia! Santa Virge Maria, intercedei junto de Deus por mim! - este peditório era feito três vezes em seguida, c'as mesmas palavras. Outro papel trazia a promessa de dar duas velas pro altar do Senhor Menino e uma reza da Virge, se lhe saísse o desejo realizado.

Transformou-se, o Nicolau das brotas: de muita graxa que tinha, ficou chupado das bochechas e do cangote, desmereceu dum modo que nem que tivesse estado doente. Chegou a ponto, uma vez, de passar certa mulher por perto dele e dizer: - seu Nicolau, não foi à toa que eu lhe falei que não mexesse tanto pra aquelas bibocas da Guamixama, que há lugares ali bem maleiteiros. O resulttado mecê 'tá vendo! - ele ameaçou um sorriso, como resposta, mas o sorriso saiu amarelo e desconsolado. E a tal dona deu de contar a quanta gente havia que, se o Nicolau não bebesse raiz de tomba ou de maricá e não comesse uns dois quilos de sulfato, rodava pela água abaixo.

O freguês principiou a rondar as vizinhanças da Lidubina, dia e noite: disfarçava como quem estivesse a procurar um morador da rua, um morador que sumira por tal forma que nunca mais podia ser encontrado. Ora, nesse pedaço de tempo o Zeca Lorindo, moço de peito e presença, enfeitiçou-se pela cabocla. O Zeca Lorindo é um sujeito que não tem medo de tomar um compromisso, por maior que seja, porque sabe que se desenleia com facilidade. Tirar a Lidubina era uma coisa, a bem dizer, impossível, porque ela não havia de querer outra vez cair no mesmo laço; atirou o anzol, mas a isca voltou sem nenhum belisco; botou contas à vida, remexeu na cabeça, pôs o dedo no queixo, um dia, pensou, pensou - e assentou de casar. Falassem, dissessem dele o diabo, nada lhe importariam as prosas do mundo, pois não vivia almoçando e jantando na mesa dos mais. Afinal... E aquilo ficou mesmo, lá na cachola do manata, firme que nem rocha de pedra.

Se bonito cuidou, mais bonito contou. A vila inteira foi logo senhora da notícia que Zeca Lorindo ia mandar seo promotor notar uma carta pedindo casamento pra Lidubina. Uns intentavam trelar co'a nova, cortar na casaca do outro murmurando: e na horinha barganhavam de tenção, só de se lembrarem que o tal, sabendo dos cortes, não cochilaria pra se desobrigar. Paga a pena ser moço de respeito assim! Até essas velhas gaiteiras, que só 
vivem de casa em casa bulindo c'os segredos alheios, não tinham ânimo de se ocuparem do nome dele!

Assim que chegou aos ouvidos dos pais da lidunbina aquele rumor, foi um festão pros pobres dos velhos: achavam que o Zeca Lorindo estava nas condições de fazer uma linda vida co'a rapariga, arranjaram seus planos, trataram de ajuntar umas economias pro divertimento, puseram-se em dia c'os serviços atrasados, afim de os serviços renderem algum pouco, e esperaram a carta. A carta não tardou: receberam-na um dia de sábado, ali pela boca da noite, levada pelo pai do dito moço, escrita c'ûa mão de pena boa que dava gosto. Só a Lidubina mesmo era quem lia por cima, de todos da familiage: foi ela, pois, quem leu as letras. No fim os velhos falaram que ali a pessoa mais interessada acabara de ver o pedido; por isso que respondesse bocalmente. A Lidubina foi até a varanda, apegou-se um instante co'a Senhora Aparecida, e veio c'o sim na ponta dos beiços.

Houve um barulhão na vila. A mó' que sempre que ûa moça vai casar todas as outras têm um defeito pra pôr na noiva: assim aconteceu, inda mais com quem! - c'uma coitada que tinha telhado de vidro! O guaiú foi bater nas orelhas do Nicolau das Brotas; não havia remédio como não batesse; ele ficou pras pontas dos dedos e, se se sentia amagoado, mais amagoado se sentiu daí por diante, quase sem juízo, a falar verdade. E uma vez se queixava de a antiga companheira o largar e se amarrar c'um estranho, houve um destrocido que se saiu com esta:

- O que, Nicolau? Você pensava antão que a Lidubina é brejo pra porco fuçar?

Esteve em ares de enlouquecer, o Nicolau. Não enlouqueceu, de certo, porque um cristão meio avariado não tem realmente grandes esp'ritos pra perder c'os baques que a sorte lhe dá. Apenas, que depois do aludido casamento, garrou a viver uma vida diferente do resto dos homens: não queria mais saber de gente de saia, derretia-se meses e meses pelas matas e pelas furnas, rebuscando plantas e raízes de medicina - cipó-sumo, sussuauá, sessenta-feridas, cipó-caboclo, perogaia, japecangas - e virou um curador de primeira qualidade, os caçadores muitas vezes topavam na ribanceira do rio c'um vulto arcado pro chão, segurando uma faca e algum talo de erva ou algum ramo de trepadeira; aravam pra fazer que ele provasse o virado da pândega ou molhasse a garganta co'aquela agüinha que gato não bebe: tempo escusado, 
porque o Nicolau só se enchia de coqueiros e mel que ele mesmo derrubava ou furava, tudo mexido e comido no guatapé, e nada mais punha na boca.

Recomendava a banha da capivara pra curar essas roncuras de constipado meio estuporado; o óleo do cacho da anta pro reumatismo; a gordura do cuatí pra fazer crescer o cabelo e curar as mataduras dos animais; a enxúndia do jacu pra botar nos ouvidos, como remédio pra surdez; a carne do pica-pau chanchã pros mudos mamparem e recuperarem a voz ou aprenderem a falar; o moquém de bugio ou de mono, como fortalecente, por serem de muita sustância; os xarques da onça pintada ou saçuarana, pra esses caroços que dão no pescoço da gente, escrófulas: e um chuveiro de graxas e banhas e óleos e carnes do sertão pra diversos incômodos.

Ganhou fama. Vinha povo de longe, atraído pelo nome do Nicolau, buscar umas garrafadas que ele aprontava e eram danadas pras boubas; um vinho macota de bom pra desinchar as pernas de quem andava com hidropisia; um xarope que era um porrete pra acabar co'a catarreira dessa doença que tem aparecido, a influência: e, fosse porque mais vale a fé que o pau da barca ou porque as drogas fossem virtuosas, todos se diziam sastifeitos co'elas. Despois, o Nicolau não especulava co'as curas e c'os remédios: isso inda mais servia pra aumentar o merecimento do curador.

Um dia de sábado, remexendo o Nicolau uma capoeirinha rala que tem ali perto da Maria Alves, em procura de uma tal planta chamada traquá, que dizem ser truco-fecha pros hernes, ouviu gritarem-lhe o nome umas par de vezes, com teima e com ânsia.

Virou-se no rumo do chamado, abaixou-se um pouco rente c'o chão, pras folhas das arvinhas não lhe estrovarem os ouvidos, e percebeu que a voz rompia da estrada-mestra da fazenda, mais ou menos por ali assim pelo café novo do Batista Severo. Saiu da capoeira, c'um dilúvio de ramos debaixo do braço direito e a faca na mão esquerda, apareceu na estrada. Nem bem botou a cara no limpo, já um cavaleiro correu de longe os garfos nas paletas da mula saina, em que estava montado, e aproximou-se à toda.

- Seu Nicolau, foi logo falando o supradito cavaleiro: venha ra vila acudir ûa mulher que 'tá pra uma dependura, se Deus abaixo de Deus vancê não lhe der alguma volta!

- Mas quem é? - perguntou o Nicolau.

- Home, eu não sei: venho de favor, não indaguei de nada. 
- Mas adonde mora a doente?

- Ela assiste ali na virada da Vila Velha pra Vila Nova.

O Nicolau matutou um instante. Não se recordava de ninguém nas condições de se ver doente morre-não-morre, pra aqueles lados, duma hora pra outra. E o recadeiro foi-lhe pedindo, já no sufragante, lhe montasse à garupa da mula, que era um raio, e daí a coisinha estariam chegando.

O curandeiro fez um maço da ramalhada, que entafulhou num saco de picuá: amarraram-no ao rabicho da mula, o curandeiro largou um pulo, sentou na garupa, e a saina descanhotou-se numa retirada de mil demônios, ligeira que nem tinha altura.

Daquele lugar até a vila tinha quindau, não há dúvida, mas a pressa encurtou a distância: não gastaram mais que uma hora pequena pra chegar. Logo na porta da casa o Nicolau teve um estremeção, porque encontrou um homem que lhe era muito conhecido, mas muito mesmo: o Zeca Lorindo, sem mais um ponto, sem mais uma linha. E pegou a pensar e a estudar lá consigo:

- Ora quer ver que a Lidubina é que 'tá nas últimas, ora quer ver?

Aquela idéia fazia-lhe uma dor endemoninhada: a cabo de tantos dias, de tantos meses, de tantos anos, vir topar c'a dona do seu coração no fundo duma cama, vai-não-vai! Isso era um desespero! Mas no mesmo momento dava de cuidar outras coisas: qual! Havia de ser alguma conhecida, alguma parenta do Zeca Lorindo. A Lidubina, essa inda há pouco tempo ele tinha sabido que estava residindo pros lados do Piraju, onde o Zeca abrira um cultivado, na fazenda do Douradão.

Também, graças a Deus, ninguém o conheceu na casa. Foi entrando, a pedido do próprio Zeca Lorindo, pela morada a dentro, até o quarto onde se achava a doente, quase já com pérca de fala, segundo logo lhe contaram. O quarto era pequetito, mal apenas tinha cabimento pra um catre novo, onde a Lidubina (era ela, era a Lidubina!) padecia em demasiado há quase um mês. Ele vizinhou c'o dito catre, olhou pra moça, que a mó' que estava meia fraca do juízo, de tamanho febrão que andava tendo, e ficou distraído uma temporada, c'os olhos pregados naquele sembrante, sumido e cheio de tristeza.

Tristeza, então, foi a do Nicolau das Brotas nessa horinha! Mas não disse coisa alguma: segurou a mão da outra, estendeu-a numa das suas, pra ver o sangue que a moça inda tinha no corpo, como despois explicou, apalpou-lhe o pulso, que estava longe como aquela 
serra da fartura, foi o que despois disse: e abriu-lhe a boca de vagarzinho, pra ver a língua, que estava seca e branca que nem o pedregulho do palmital, contou também despois.

E falou bem compassado, pra ninguém não perceber o sofrimento que ele sofria:

- Acho que esta dona 'tá c'uma febre das fortes e c'um pleuriz daqueles mais apertados. O que é que ela tem bebido?

A dona tinha bebido muita coisa: um pozinho claro que seu Maneco Alvim perparou, pra misturar no café; um remédio de vidro que seu capitão Baltazar tinha mandado; umas pílulas que seu capitão Negrão aprontara: e, por derradeiro, quando entrou em ficar cada vez mais ruim, um vinho muito escuro e muito amargo que seu doutor Chiquinho receitou na véspera. E ficou sempre daquele jeito!

A tarde vinha caindo, serena e quieta, ver o sono duma criancinha de berço. $\mathrm{O}$ Nicolau encostou-se à janela do quarto, que fazia esguelha pra mata do Pio, nas terras de São Domingos, e pôs-se a olhar um montão de nuvens cor de ouro vivo que foi formando castelo em riba das árvores. Largava de olhar pra aquelas nuvens doiradas, olhava pro sol vermelho que ia afundando na lonjura dos morros: e de repente viu que lhe aparecia (não foi nada mais que uma visão) a Lidubina entre as nuvens e o sol no espaço livre, linda como os amores, vestida de branco, de chinelinhas cor de rosa, c'uma flor avermelhada no cabelo e os olhos mostrando amor.

Se ela estivesse morrendo? Aproximou-se do catre: a suspiração chegava de longe em longe, o sembrante parecia sumir cada vez mais, o nariz ficava cada vez mais fino e os olhos cada vez mais amagoados. Foi aí que ele mandou buscar o picuá, pediu que todos se retirassem, porque ninguém não podia ver o remédio que a moça tinha de beber, ele mesmo juntou uma folharada, botou numa chocolateira aquela folharada toda, e fez um chá que foi dando pra doente, de instantinho a instantinho.

Por volta das oito da noite a Lidubina puxou uma suspiração bem do fundo do peito, com todo o sossego, pendeu a cabeça pra um travesseiro menor e mais baixo, e principiou a dormir descansada que nem uma pomba rola. O Zeca Lorindo, de tresnoitado que andava, e de alegre que se viu, logo teve jeito de conciliar o sono perdido: e o Nicolau ficou fazendo quarto pra Lidubina, sozinho de tudo, lembrando coisas de rir e coisas de chorar, na viração do passado... 
A primeira notícia que o Zeca Lorindo teve, na meia sombra do sono ainda ao romper da manhã, foi o próprio chamador do Nicolau das Brotas quem lhe deu:

- A sua dona sarou duma vez, patrão.

Ele não teve mão em si, correu como um louco pro quarto:

- Morreu?

- Não, seu Zeca, foi roubada.

- Como é que foi roubada, seu maldiçoado do inferno?

- Foi bem: aquele Nicolau já me contaram que é o Nicolau das Brotas: vancê não pôs reparo no home? Foi a soneira braba que voltou, despois de tanto tempo: na certeza inté levou nhá Lidubina carregada.

Um itapicuru passou por cima da casa, fazendo um barulhão desapoderado. O Zeca Lorindo trouxe pra porta do quintal a espingarda troxada alcançadeira, e disse ûa ameaça:

- Canta, filho do diabo! Canta, que eu te mato e mato por igual aquele desordeiro!

Mas o Nicolau das Brotas aprendeu, na sua vida de monge, o que faz viver e o que faz morrer, decorou rezas tiranas, tivera caborge e corage: nunca mais o Zeca Lorindo lhe pôs a vista em riba, porque ele foi pro Guaíra, mais a Lidubina, e só Deus sabe onde é que eles fizeram a arranchação perigosa, na terra da bugraria. Agora, quando se fala naqueles dois sertanistas e se toca no nome do Zeca Lorindo, não falta quem não diga:

- Quem planta na capoeira é como quem lambe osso. Capoeira é sempre capoeira, não paga o trabalho que dá... 


\section{Análise do conto}

"Soneira brava" é um dos cinco contos (juntamente com "Castigo do céu", "Bocó-demola", "Reis" e "Forte teima!") aos quais Carmen Lydia de Souza Dias chama de "estilisticamente imaturos", pelo fato do autor não ter conseguido resolver de forma satisfatória a convivência entre narrador e personagens, quanto à adequação do discurso do primeiro em relação ao dos segundos. ${ }^{68}$ Porém, na narração da fuga da personagem Lidubina, o autor-narrador demonstra uma grande acuidade perceptiva e envolvimento com a natureza. Um bom exemplo está no trecho em que se observa o quanto um fenômeno natural (o pôr-dosol) influencia o estado de espírito da personagem:

“(...); trabalhador como sempre foi, de dia andava esquecido no serviço da oficina de carpinteiro, e estava tudo direito: mas assim que a barra do dia começava a sumir no encontro do céu co'a cabeça dos espigões, o pobre vinha sentar-se à porta da casa, matutando nas suas tristuras, encarangado como se sofresse grande frio".

O fim de um dia e o início da noite metaforicamente podem representar uma mudança interior em Nicolau. O dia sugere a alegria de viver, e a noite, a tristeza. Com a escuridão, as "tristuras" emergem com grande intensidade.

Um traço estético do realismo/ naturalismo presente no conto é o envolvimento do caipira Nicolau com a flora e a fauna, não no sentido de exaltar a beleza de ambas, mas sim tomá-las como objeto de estudo científico, ainda que rústico, para curar certos problemas de saúde. Isto é observado na seguinte passagem:

"Recomendava a banha da capivara pra curar essas roncuras de constipado meio estuporado; o óleo do cacho da anta pro reumatismo; a gordura do cuatí pra fazer crescer o cabelo e curar as mataduras dos animais; (...)".

No conto abundam arcaísmos. Alguns deles são: "adonde", "estrovassem”, "escuitando", "berraria", "tristuras", "traidoria", entre outros.

\footnotetext{
${ }^{68}$ DIAS, Carmen Lydia de Souza. Paixão de raiz: Valdomiro Silveira e o regionalismo. São Paulo: Ática, 1984. p. 195.
} 


\section{$\underline{\text { Reis }}^{69} 70$}

O melhor presépio que se fez, esse ano, em Lorena, foi com certeza o da casa do João do Santo, um home que não era rico mas arremediado, e tinha uma filha de mão boa de mais pra um serviço fino assim, chamada Ginerosa. Já de longe, reparando no jeito em que estavam postas as flores, armada a arve de bacupari, cheinha de frutas doiradas, e arranjados os três reis e o Senhor Menino (que por sinal era gordo e corado, muito alegre) e nossa senhora e S. José e a jumentinha e o burrico, todos diziam:

- Qual! Pra estes perparos não há mesmo outra que nem a Ginerosa!

Ela então andava numa dobadoura, vai pra aqui, vai pra ali, atendendo às visitas, recebendo os presentes, dando as lembranças que cada um queria do natal, e rindo, rindo, que era só aquela alegria!

Quando foi sendo meia-noite, o João do Santo repontou o povo todo pra missa do galo: algum piá que estava meio morrinhento de sono, saía um tanto atropelado, que ele assobiava no ouvido do tal, e não havia como o piá não levantasse; a nhá Rita, mulher do dito João do Santo, redonda de graxa, a coitada, via-se num tipiti, pra caminhar a par de tamanha gentarada, e (com perdão da palavra!) ia bufando que nem um redomão que acabou de tomar um galope decidido. A Ginerosa, com sua saia de balão entusiasmada, estava de matar.

Assistiram à missa, que acabou ali por volta de uma hora da madrugada, porque seo padre vigário, um velhinho já cata-cego e rouco, mal podia enxergar as letras do livro santo e falava numa voz baixica mesmo. E já iam indo de volta pra casa na virada de uma esquina...

... quando rebentou de uma outra o bando dos cantadores de reis, pedindo esmolas pra última festa do nascimento de Nosso Senhor. E que bando destorcido! Não contando o povaréu do acompanhamento, que estava duro deste feitio, lá se via bem à frente, todo concho c'a sua viola marchetada, em cuja cravelheira tremia uma fita vermelha comprida, o Antoninho Cabo Verde, pisando em lã e em ovos, e o Chico Pintassilvo, c’o machetinho na mão, olhando por cima de tudo, serenando de contente.

\footnotetext{
${ }^{69}$ Nota CLSD: "Escrito em Casa Branca, em janeiro de 1898". O conto possui versões nas pastas Mucufos e Originaes manuscriptos de Papae (preciosíssimos).

70 Nota da edição: O conto possui versões nas pastas Mucufos e Originaes manuscriptos de Papae (preciosíssimos).
} 
Senão quando o machetinho picou e a viola foi só rasgando, ao passo que aquele mundão de caboclada cantava num coro alto:

\author{
"Ó de casa nobre gente, \\ escutai e ouvireis: \\ lá da parte do oriente \\ são chegados os três reis."
}

E verso e mais verso, um em riba de outro, numa cantoria tão bonita que, depois que o barulho tinha acabado, muito tempo, a gente inda cuidava estar c'os ouvidos encantados de tão linda toada!

Assim que o bando fronteou a casa do João do Santo, o Chico Pintassilvo, que vivia numa paixa desapoderada pela Ginerosa, percurou aproximar-se dela e, com todo o respeito, a bem dizer até um pouco enleado da língua, pediu-lhe qualquer cousa pra festa de reis. A Ginerosa, Cristo Deus - ficou atada dos pés e das mãos, naquele instante: mas sossegou, mal e malzinho, foi pra dentro, voltou pra fora, trouxe uma moeda de ouro, das de meia dobra ainda, e disse-lhe estas palavras:

- Olhe, nhô Chico: a única coisa que eu pissuo de meu é esta moedinha, que vai dada de coração.

Ele agardeceu, afastou-se cada vez mais atrapalhado, deu adeus, foi-se embora.

E o bando dos cantadores ia pintando o caneco pelas ruas, fazendo um rumor desesperado. Começava a arruivar-se um ladinho do céu, que depois ficou vermelho, e depois amarelo, p'r amór de o sol. A rapaziada, que estava tonta de sono, sumiu como por acaso: a Lorena caiu logo num sossego, num sono também que, mal comparando, parecia de ares de çumitério.

O peditório ia desde o Natal até os Reis, todo dia. Formou-se aquele ano um terno que então sabia folgar direiro, com cada peito limpo que não tinha corage de negar uma dávida qualquer. Mas não podiam receber dinheiro em nota, porque, segundo a voz geral nunca houve notas lá por Belém; outra: quem não tinha de seu um vintém, um quarenta, um 
cobre paraguaia, entregava frangos, leitoas, frutas, bobages que servissem pra se venderem no dia último das festas.

Amanheceu o legítimo dia dos Reis. Povo estava assim no largo da igreja. Nem bem foi ouvida a missa, já todos se esparramaram por ali fora, pra verem o bando uçu de cantadores. Seo padre vigário, o pobre! - assim que passou entre eles, arcado por via da idade, murcho do rosto, fraco dos olhos, não teve mão em si que não deixasse duas lágrimas correrrem-lhe pelo rosto abaixo. Decerto seo vigário, no tempo de moço, também foi do chifre furado com argolinha na ponta, decerto gostava bem de suas patuscadas e folias: agora, acarcanhado e preso por aquele vestido preto, o único remédio que lhe sobejava era mesmo chorar, o pobre!

O machetinho gritou só no fundo do largo, e daí a um baque a viola repinicou buliçosa e sirigaita, acompanhando, e a moçada reuniu-se perto do Antonio Cabo Verde e do Chico Pintassilvo. E lá foi o povão, cantando.

Tinha umas moças que apareciam, de vez em vez, e pediam festas por este modo, enjoadas de mais:

$$
\begin{aligned}
& \text { "Moço formoso e cortês, } \\
& \text { eu quero o meu Reis." }
\end{aligned}
$$

Quando o sol estava querendo morrer lá pra umas serras grandes que pareciam espetar o céu, de tão finas na ponta, a moçada foi pras casas onde tinha presépios, porque era a hora de leilões de tudo quanto havia. Vendia-se tudo: as folhages, as flores, as frutas, os animais: só a Santa Família, os Reis, a jumentinha e o burrico não se vendiam, ficavam pro presépio do ano que vinha. Apareciam uns ovos da ascenção, enfeitados de fitas, e o leiloeiro gritava, a mó’ que esbaforido até:

- Afronta faço que mais não acho! Um ovo da ascenção, ovo que não apodrece, que dá felicidade, que traz fortuna! Dou-lhe uma, dou-lhe duas! E lá vai o ovo da ascenção por vinte mil réis!

E ia às vezes por mais, cada ovo! Também, quem arrematava um daqueles, guardava-o bem, com todo o carinho, porque é certo que faz ventura e tem o cheiro perfeito do benjoim com que a pecadora banhou os pés de nosso senhor, quando ele já era home e ela era morena muito fermosa, conforme dizem aqueles livros que têm a vida de Nosso Senhor. 
Chegou a hora da casa do João do Santo; pra lá se dirigiu a rapaziada, que levava um cesto macota de dinheiro e quanta criação e coisa de mesa se pode imaginar. Foi o presépio arrematado, pedaço por pedaço: e a Ginerosa, que já se acostumara com ele e beijava toda hora o Menino Deus (porque contam que quem tem fé c'o Menino Deus consegue tudo quanto quer) viu ir saindo tudo: os carneiros, a graminha da manjadoura, os jasmins de um lado, os cajus de outro, e os anjinhos pendurados das folhas de caeté com flor que ali faziam figura, tão engraçados com suas asas de cor!

Por derradeiro, assim que tudo se entregou aos lançadores, no leilão, o capataz do bando que era o Antonio Cabo Verde, foi mandar fazer a ceia co'aquela dinheirama, e aprontar quanto pato e marreco e veado e paca tinham ganhado.

O Chico Pintassilvo, esse não quis saber de mais nada: folgar por folgar, antes ali perto da Ginerosa, seu tanto escondido, confessando tudo que sentia por ela, tal e qual um que está aos pés do padre, em segredo. E a Ginerosa, que lhe percebeu o jogo, logo-logo achou talho de conversar com ele, junto da arvinha de bacupari que inda balançava a um canto. Quanta coisa não conversaram, quanta! E foi depois de muitas horas, quando já estava roncando na sala dum vizinho o realejo do baile pra depois da ceia, que o Chico, assim c'a voz quase presa, receoso, contou pra Ginerosa:

- Ginerosa, amanhã, se vancê me der licença e Deus me ajudar, eu vou falar pra seu pai no casamento.

- Fale, nhô Chico - ela respondeu: fale, e fique na certeza que a melhor festa que vancê me podia dar é esta mesmo.

Depois, assim que não se via mais viv'alma na sala do João do Santo, além do Chico, e o baile inda não tinha principiado, a Ginerosa foi pro quarto, puxou o Menino Deus da caixa dos vestidos, abraçou-o, uniu-o bem aos peitos, e pegou a murmurar como se fosse às orelhinhas dele:

- Bem se diz, meu abençoado Menino Deus, que quem se apega com vós consegue o que deseja. Bem se diz!

E como já a tinham chamado umas par de vezes, saiu do quarto cantando.

O realejo roncava na casa do vizinho. Daí a pouco principiaram a dançar o baile, c’um estrépito danado. E o Chico Pintassilvo, distraído na sala do João do Santo, fazia que estava olhando as flores doiradas do bacupari, mas o que estava o que estava era olhando a porta da varanda pra não peder nem um pouco de tempo de contemplar a Ginerosa. 
Ela apareceu, daí a bocado, e tanto que entraram no baile (isso é que foi a gana das moças e dos moços!) deram logo nas vistas, de tão jeitosos que iam. Seo padre vigário, que se sentara um momento ali na sala, por comprazer aos donos da casa, foi logo pra perto deles: e com a mão aberta, explicando não se sabe o que, aos dois, parecia estar já abençoando-os... 


\section{Análise do conto}

"Reis", assim como "Soneira brava", é um conto "estilisticamente imaturo"71 pelas razões expostas anteriormente.

"Reis", segundo Carmen Lydia de Souza Dias, revela "uma vontade enorme do autor, de contar as "folias". O narrador faz um constante uso do tempo pretérito imperfeito para descrever os ricos detalhes das "folias". Juntamente com o pretérito imperfeito, observamos o uso do pretérito perfeito para "reinstaurar uma atmosfera narrativa apta a acolher/exaltar o caso de amor da personagem Ginerosa com o Chico Pintassilvo".

A mistura dos acima referidos tempos verbais proporciona algumas "descrições narradas" das comemorações de Natal. E isso é feito em fala caipira, muitas vezes bem desenvolvida lingüisticamente, e que marca toda a trama do conto. Esta é paralisada a todo instante "pela ênfase colocada na parte descritiva dos folguedos: peditório, evoluções, leilão, baile:

“.. quando rebentou de uma outra o bando dos cantadores de reis, pedindo esmolas pra última festa do nascimento de nosso senhor. E que bando destorcido! Não contando o povaréu do acompanhamento, que estava duro deste feitio, lá se via bem à frente, todo concho c'a sua viola marchetada, em cuja cravelheira tremia uma fita vermelha comprida, o Antoninho Cabo Verde, pisando em lã e em ovos, e o Chico Pintassilvo, c'o machetinho na mão, olhando por cima de tudo, serenando de contente."

Carmen Lydia de Souza Dias chama a atenção para um outro trecho do conto onde supostamente o narrador tenta convencer o leitor do intenso amor e do iminente casamento entre Chico e Ginerosa, através da presença e das palavras de um padre que estava na casa onde acontecia um certo baile:

"Seo padre vigário, que se sentara um momento ali na sala, por comprazer aos donos da casa, foi algo pra perto deles; e com a mão aberta, explicando não se sabe o que, aos dois, parecia já abençoando-os...”.

Carmen Lydia de Souza Dias também observa, no trecho acima, que a utilização dos gerúndios "explicando" e "abençoando-os" confere um forte teor descritivo ao trecho, além da

\footnotetext{
${ }^{71}$ DIAS, Carmen Lydia de Souza. Paixão de raiz: Valdomiro Silveira e o regionalismo. São Paulo: Ática, 1984. p. 195.; nas citações seguintes, respectivamente, p. 195, 197-198.
} 
"presença descuidosa de alguém que, enlevado, "narra" uma gravura para a qual se volta e para a qual faz questão de solicitar a atenção visual do leitor".

Esse alguém pode ser interpretado como sendo o narrador que, envolvido pelo clima festivo e alegre do baile, nos apresenta uma cena que se tornou um lugar-comum do espírito romântico: a bênção concedida por um padre a um casal de noivos no momento de seu casamento.

Alguns dos arcaísmos que abundam no conto são: "home", "arremediado", "arve", “doiradas", "perparos", “gentarada", entre outros. 


\section{$\underline{\text { Capiango }}^{72} 73$}

Nhá Tereza apareceu indignada, com os olhos a afuzilarem vivíssimas cintilas de fúria, em casa de seo Virgínio, delegado de polícia que estava de jurisdução. Foi entrar à porta, e desfiar logo um rosário de queixas, a qual mais entremeada de vocativos injuriosos e praguentos: que de há muito lhe andavam rondando o casinholo, gente que ela não conhecia, nem atinava com quem fosse, tal lhe faziam de pura malvadez, porque ela, a bem dizer, nada tinha que tentasse aos outros - era uma pobre coitada sem eira, nem beira, nem ramo de figueira, como lá diz o outro.

A cada objurgação mais forte, dirigida ao gatuno ou gatunos ignorados, oscilava-lhe maciamente no pescoço, dir-se-ia congestionado de ira, um formidável papo de corda que bojava logo ao de sobre o cabeção da camisa, forcejando por patentear-se à luz meridiana. As mãos, essas já não paravam mais, iam e vinham em paralelas da direita para a esquerda, paralelas que ora minguavam, chegando quase à distância de um gêmeo, ora se faziam largas, tomando a extensão do corpo gordanchudo da oradora.

Seo Virgínio, que, por ser o dia de festa e ele capitão da guarda nacional, vestia o uniforme respectivo, no qual estava, pode-se dizer letralmente sufocado, e não sabia o que fazer do rico boné, seo Virgínio já se via desanimado ao rumor de tamanho falario, chegando a pedir a nhá Tereza dissesse de uma vez ao que vinha, o que lhe haviam furtado, quem fora o autor da tramóia, e tudo o mais que é mister nestes autos. Nhá Tereza engrolou novos xingos, agora mais puxados à sustância, acabando por dizer que lhe haviam passado os quatro soldados e um sargento em meia dúzia de frangos, um patureba, um casal de pombos camboteiros, cinco ovos de perua, de um jacá no meio do galinheiro.

Impava deveras, nhá Tereza, quando concluía a lista, mais de zanga que de cansaço pois de pequena se afizera a esgoelar por qualquer dá-cá-aquela-palha, e bastas camarinhas de suor lhe escorriam da testa, juntando-se a outros que previamente haviam brotado das faces, as quais, todas reunidas e quiçá refrescadas por uma senhora ventania que passava, fluíam na direitura do queixo, como a buscarem o rumo do papo, que, de certo, iriam refrigerar. E seo Virgínio, que tirara por instantes o boné e o pusera em cima da mesa de perova, depois de o

\footnotetext{
${ }_{72}^{72}$ Nota CLSD: "Escrito em Casa Branca, em maio de 1898".

${ }^{73}$ Nota da edição: O conto possui versões nas pastas Mucufos e Originaes manuscriptos de Papae (preciosíssimos).
} 
haver passeado de norte a sul, de uma fonte a outra, da coroa da cabeça ao toutiço, olhava para a querelante com uns olhos de todo em todo abertos, ou pela exigüidade do delito, ou do temor que sentia de ouvir em segunda edição, mais incorreta e pavorosamente aumentada, a narrativa do caso, inclusive os doestos e os baldões. Chamou então a ordenança e mandou buscar a força, recomendando a nhá Tereza retirasse para casa, onde não devia bulir em nada, para não estorvar a vistoria da justiça. (Falou assim.)

Nhá Tereza saiu de feito, gungunando ainda no fundo da garganta, como se o silêncio fosse alguma coisa que lhe fizesse espantoso mal: e assim que se achou na cancha e atirou para a cama o chale que a apoquentava, de pesado e quente, abriu-se em frases consoladas diante da filha, a Quiterinha, mostrando-se assaz confiante na boa diligência do seo capitão Virgínio, um homem de ponderação, que sabia receber os precisados de auxílio da autoridade. A Quiterinha escutava-a de olhos baixos: e em verdade se diga que as palavras da mãe lhe entravam por um ouvido e saíam por outro.

Ninguém será capaz de saber porque é que a tal Quiterinha dava tão grande sorte nesta Casa Branca cheia de moças bonitas, quando não era lá essas coisas de formosura e tinha as feições meio caídas para o queixo, sob o qual se viam duas papadas vermelhas de uma gordura entretida a fartas refeições de feijão guando, angu de fubá grosso e carne de vaca mal assada. Ninguém será capaz, a não ser que lhe tenha reparado, em tempo oportuno, em as ancas roliças e bamboleantes e no gracioso andar, que mais as faziam tremer com arte e segurança. Dava sorte, a Quiterinha, cobiçavam-na uns tantos cata-fechos, que gandaiavam dias áfios rebuscando jeito de lhe falarem, mas o que é certo é que ela não deixava de ser bem esperta e continha-os à lonjura, insaciados e sempre desejosos. Destes se diz isto: e outro tanto não se podia dizer do Chico Marceneiro...

Nhá Tereza compôs a casa por dentro, mandou à filha que se aprontasse, não na fossem ver esses homens desarranjada assim, puxou uma mesinha de costura para o meio da varanda, onde pudessem fazer as escritas precisas, e ficou à espera.

Não esperou muito tempo. Daí a nada chegava seo Virgínio, cada vez mais sumido nas suas roupas afogantes, ladeado de um meirinho e seguido de seis praças. Depois de pedida a necessária vênia, com o máximo respeito, dirigiram-se todos ao quintal onde se dera o furto, durante a noite, segundo a exposição da queixosa, que ainda agora se desentranhava no reconto do caso, já outra vez tomada de furor mal contido. 
Examinado o quintal, verificou-se que havia passadas recentes, de pés grandes, desde a cerca pauapicada até uns canteiros de grama que morriam debaixo da janela da Quiterinha; naquela direção, realmente, viam-se pegadas humanas, imprimidas no chão, ao que parecia pelo tamanho, por gente macha. No galinheiro, porém, nada se observava extraordinário, fazendo-se exceção de um jacá de galinha botadeira atirado abaixo, naquele flagrante, por um galo brigador que se aterrorizara à chegada do delegado, do meirinho, e dos guardas. Reparava-se, mais, que um cateto manso, que se aquentava ao sol, também não ficou satisfeito com aquela invasão, e foi-se deitar mais longe, rente de umas taiobas, à beira da fonte.

Seo Virgínio, com quanto zelo deve ter uma autoridade, devassou todos os recantos, e nada encontrou anormal, fazendo ver a nhá Tereza que, se não se notassem aqueles sinais de pés até os canteiros de grama, poderia jurar-se que no quintal não entrara ninguém, muito menos no galinheiro. E nhá Tereza tornou-lhe:

- Qual, seo capitão! Isto é capiango que sabe fazer as coisas bem feitas, que conhece muito a minha casa, na certeza.

Como quer, porém, que ela fosse olhar um cesto velho, ao canto do galinheiro, qual não foi o seu espanto ao achar ali os ovos de perua que cuidava terem sido tirados! E por ser justamente à hora do sol ficar mais bravo, a que as criações iam beber, emboladas, à fonte, nhá Tereza descobriu, com alta admiração, a meia dúzia de frangos transviados, e o patureba, e o casal de pombos camboteiros. Pediu desculpas a seo Virgínio, muito avexada, dobrando as pontas do lenço entre as duas mãos convulsas.

Seo Virgínio, entretanto, que atentara na Quiterinha, vira-lhe os olhos afundados nas órbitas, as feições meio pálidas e chupadas de noites mal dormidas, e, principalmente, a turvação dos modos, respondeu a nhá Tereza, saindo, entre risonho e sentencioso:

- Ora, nhá Tereza, afinal o que lhe furtaram, o que lhe poderiam ter furtado, não hai justiça na terra que lhe o possa dar outra vez! 


\section{$\underline{\text { Análise do conto }}$}

"Capiango", cujo título nitidamente regionalista marca o falar caipira, é quase todo narrado em terceira pessoa e com poucos diálogos. Possui como temas a sexualidade feminina e a transgressão da moral vigente. Pode-se dizer que "Capiango" é um conto da fase experimental de Valdomiro Silveira, no sentido de ser mais um repositório do caso para futura reelaboração. Ou melhor, mais que um caso, tem-se uma anedota, na qual o narrador-autor faz uso do suspense e de uma boa dose de erudição gramatical (do ponto de vista sintático e morfológico), mostrando assim um certo distanciamento em relação ao falar caipira que, no conto, não é bem desenvolvido. Podemos observar a erudição do narrador logo no início do conto:

"Nhá Tereza apareceu indignada, com os olhos a afuzilarem vivíssimas cintilas de fúria, em casa de seo Virgínio, delegado de polícia que estava de jurisdução".

Podemos observar, no segundo trecho em diálogo do conto, a presença do coloquialismo culto, onde a erudição é refreada e a fala caipira praticamente não aparece com nitidez:

“- Ora, nhá Tereza, afinal o que lhe furtaram, o que lhe poderiam ter furtado, não hai justiça na terra que lhe o possa dar outra vez!"

“Capiango" não apresenta abundância de arcaísmos como outros contos. 


\section{$\underline{\text { Forte teima! }}^{7475}$}

Por falta de aviso não foi. Toda a gente da ilha grande aprofiava em dizer ao Zé Tucura que não arrodeasse a casa da Oncinha: a Oncinha é uma cabrocha bonita, não há dúvida, mas o bonito às vezes serve só de longe. Ele bem sabia que sô Moraes, moço de opinião, gastava co'a cabrocha e não havia de querer sociadade assim sem mais nem menos. E o Zé Tucura encabeçou naquilo: porque sim, porque era seu desejo, porque havia de fazer a acontecer, nem que o céu viesse abaixo, quanto mais sendo a questã c'um filho de Deus como ele mesmo! Em certas coisas o falado é bom, mas o feito ainda é melhor!

Sô Moraes até que não era tocado a valentão: vivia de seus ganchos, pra um lado e pro outro, comprando café no sítio de nhô Tino pra vender na casa do Gervásio, barganhando um tordilho por um baio, recebendo dinheiro aqui pra mandar pra São Paulo, enfim fazendo seus arranjos caladinho e sem mexer co’a vida dos mais. Por andar pelos vinte e cinco anos e ser sacudido que nem um marruás, percisava ter uma companheira que fosse também mocetona e sadia, e tirou a Delminda dos pais, segundo se diz, de concórdia co' eles: como a Delminda nesse tempo tinha um senhor gênio muito zangado, ele batizou-a por Oncinha, e Oncinha ficou sendo o nome dela. Ora vai-se ver sô Moraes, um sujeito bem pacato, às voltas c'um demônio que não tem miolo na torre.

O Zé Tucura, outrora, teve seus caprichos pela Delminda, lá isso teve, que não há quem não saiba. Ela mesma, pra dizer agora verdade inteira e sem mistura, não deixou de não gostar um pouco dele. Negócio passageiro, nuve' que logo passou, porque o Zé Tucura deu mostra de ser um grandecíssimo preguiçoso, num ajutório que houve no rocio do pai dela, um grandecíssimo preguiçoso que, além de tudo, não tinha pulso, pegava o guatambu ${ }^{76}$ e $\operatorname{logo} o$ largava, esbaforido e desfeito em suor. Pois qual é a moça de juízo que há de morrer de amores por um marica amolentado assim? Não tinha arrumação nenhuma co'ele, fosse bater a outra porta: isto não foi dito bocalmente, mas foi dado a entender e foi entendido.

\footnotetext{
${ }^{74}$ Nota CLSD: "O Estado de S. Paulo, $1^{\circ}$ fev. 1902. (Escrito em Sta. Cruz do Rio Pardo, em 1897 e terminado em Casa Branca, em 1902)".

${ }^{75}$ Nota da edição: O conto possui versões nas pastas Mucufos e Originaes manuscriptos de Papae (preciosíssimos).

${ }^{76}$ Nota da edição: Segundo FERREIRA, Aurélio Buarque de Holanda. Op. cit., p. 875, trata-se de um brasileirismo corrente nos estados de Minas Gerais, São Paulo e Goiás que, na linguagem popular, significa enxada. Em São Paulo, em certos lugares e nos meios populares, também pode significar cabo de enxada.
} 
Agora, passados dois anos, o mato seco reverdeceu e, por sim ou por não, entendeu o Zé Tucura que havia de entrar na casa alheia pelo coração da moça. Pensou lá consigo que aquilo era só chegar e bater, porque já estivera lá dentro uns tempos: mas não se lembrou que coração de mulher é feito uma estalage', que acolhe a muita gente, co'a diferença, porém, que aquele viandante que uma vez saiu não pode mais ter pousada, volte quando voltar. Assim se deu, tal e qual: a Oncinha ensinou-lhe o andar da rua. P'r amór de ela proceder desse jeito, ele queixou-se todo amagoado:

- Ah! Delminda, você bem se vê que merece o apelido que tem, depois que 'tá nessa vida de fadista!

- Decerto - pregou-lhe ela: o nome deve de ser como traste, não parecendo c'o dono, é furtado. E olhe que eu sou de poucas prosas!

- 'tá bom, tá bom: não lhe amassarei mais as gramas de sua porta.

- Pois é 'bséquio que me faz.

Ele ficou fera. Já se viu como uma piguancha à toa queria fazer pouco num rapaz peitudo e couro-n’água como ele? Já se viu o desaforo? E levou uma temporada a xingá-la, afirmando que ela era uma infeliz sem entranhas, que arrecebia uma antiga amizade do mesmo modo que se arrecebesse uma visita do demônio. Tudo isso em pura perda, porque a Oncinha estava longe, não lhe querendo dar mais palha, e a sala de chão escura que nem tinta. Por fim lá se foi ele, resmungando de raiva; e não reconhecia dentro de si, nem por nada, que se sentia possuído mais de tristeza que de raiva. Quase todos são assim!

Então que teima era essa do Zé Tucura, de continuar na ronda, todo santo dia, da casa da moça? Pois não tinha sido tocado? E ainda que não tivesse sido tocado, pois não reparava que a outra vivia em boa paz c'o dono e a gente não pode sem mais aquelas bulir c'o guardado alheio? O sonso queria mas era lenha, com toda a certeza, ainda mais depois que tantas pessoas de peso lhe deram o voto de não passar a miúdo por essa cercania. Queria lenha ou coisa mais pior -, andavam rosnando uns tais que sempre falam acima do superlativo e não admitem que se possa pôr de banda um conselho que eles dão.

Um dia que se encontraram vizinhando co'a capela, sô Moraes pediu-lhe:

- Seo Zé Tucura, o senhor todas as manhãs e todas as tardes passa e repassa pela minha porta, não sei pra que: lá pra aqueles lados não hai morador nenhum que não seja eu mais a companheira, que não temos arranjo algum c'o senhor. Por isso eu lhe peço de favor não faça tantas vezes a medição da minha rua. 
- Ora dá-se! - enriminou-se o Zé Tucura: eu hei de ir lá quantas vezes quiser: a rua é pública, ninguém manda nela e, que me conste, mecê não tem escritura desse quarteirão.

- Não tenho escritura do quarteirão, seo Zé Tucura, mas tenho um rabo-de-tatu no cabido da sala, uma troxada atrás da janela e uma faca sempre fiel na cintura.

- Pois, sô Moraes, então os direitos que mecê tem andam igualando c'os meus, que são esses, pintadinhos.

- O senhor esteja aprevenido. Eu já cumpri minha obrigação: quem me avisa, meu amigo é.

E foi só isto. Sô Moraes é de poucas prosas, que nem a Oncinha: até murmuram que ela tem o costume proveniente duns desaguisados caseiros co'ele, no fim dos quais ela vê que o home' faz muito e fala pouco. Neste mundo o bom exemplo vale tudo!

Vieram dias, vieram meses, um em riba do outro. Sô Moraes, descansado no assunto, notava que a observação dera bom resultado, pois o Zé Tucura tinha criado parte de bicho arisco. A rua dormia seu sono de sossego, e o bairro acompanhava a rua, dês que o Zé Tucura acabara co'as indróminas e roncos de valentia e promessas de escangalhar céus e terra. Não, que isto de valentias afinal não adianta nada: parceiro que incha o papo e arregala os olhos e faz grande esparrame, nunca presta; os bons são os tais que entendem que silêncio é ouro e apenas tossem meio baixo, puxando um certo pigarro da goela, quando chega a ocasião do perigo.

A história não transpirou. Pra quê? Sô Moraes não percisava matraquear o acontecido, porque, sendo um manata de fiança, não dá trela das proezas que faz. Agora o povo é que viu dente de coelho na enleada: pois se de primeiro o Zé Tucura volta e meia transitava por aquele retiro, o que significava ter abandonado seus passeios tão prediletos que já nem notícia mandava de si? A roda parou decerto p'r amór de algum estrovo...

Cada qual indagava: ora porque seria, porque não seria? E houve um filho de Deus que achou explicação pro caso: sem dúvida aparecera qualquer pisquim na janela do Zé Tucura -, que esta gente da ilha grande é mesmo danada pra um pisquim, e trova sempre! Tiradas as contas, o rapaz com certeza leu as letras e não se sentiu com disposição de afrontar tantos empecilhos. A coisa amargou e ele intentou que era mais acertado não teimar co'a caixa de marimbondos. Dada esta explicação, todos acharam conforme e, vistos os autos, concordaram em que o diabo do namorado de água turva não passava também de um contador de maxambetas. 
Enquanto o Zé Tucura pensou que em roda de seus passos tinha caído uma noite de silêncio e ninguém via suas intenções, tudo lhe correu a gosto e prazimento. Mas no dia em que lhe contaram que o diz-que de toda ilha grande era desta maneira, Jesus! - o caboclo quase perdeu o juízo, e se é que ainda lhe restava juízo pra perder. Descabelou-se de fúria, pulou feito um tigre acuado, amarelou que nem mamão maduro, tremeu os beiços, pintou o sete. A páginas tantas caçou uma garrucha e cantou, alto e bom som, que ali dentro ia ûa mãe e dez filhos e que onde fosse a mãe haviam de ir os filhos por força.

Podia ser três horas da tarde. Bateu o chapéu na testa, pôs a arma bem à vista, e frechou na direção da casa de sô Moraes. Um casal de sivis-sivis que voava sobre o patrimônio começou a piar uns pios tão finos e tão agudos que davam ares de ser uma caçoada ao Zé Tucura. Ele nem pôs reparo nos sivis, nem em nada, porque estava baio de raiva: o sangue, correndo-lhe nas veias do pescoço com muita violência, tapava-lhe os ouvidos; e atrapalhando os olhos, que num repente ficaram vermelhos, na certeza não lhe permitia ver coisa alguma.

Quando ele se aproximou da casa, sô Moraes tinha acabado de quebrantar um burro pêlo-de-rato e ainda trazia na mão direita o relho, que era terminado por uma argola de metal grande assim. Sô Moraes desamarrava o lenço da cabeça, em pé na soleira da porta, e sofismou que uma visita a semelhantes horas, depois de tamanha ausência, era novidade e novidade grossa: encostou-se, pois, ao portal e esperou-o.

Não percisou muita demora pra adivinhar que o home' vinha c'uma veneta onça: bastava olhar aqueles passos de anta mordida da cachorrada, pra se descobrir que dali sairia forte rebordosa. Sô Moraes nem piscou e pela certa nem sentiu bater a pacuera: pôs a mão do relho atrás das costas, a outra na algibeira esquerda da calça, e 'panhou um feitio como de distraído.

O Zé Tucura já chegou bufando:

- Saia pra fora, caboclo sem raça, você que diz que é todo avalentoado, que quero dar-lhe uma lição! Pra você ficar sabendo que c'um sujeito de sangue nos olhos não se brinca! Saia pra fora!

Sô Moraes ficou parado, como quem não entendia aquelas prosas. E o Zé Tucura mais se arreliou, por ver o grande sossego:

- Eu logo vi que você havia de enjeitar a briga: fácil é o dizer, mas difícil é o fazer. Você então cuida que me há de subir na alma e que eu hei de murchar sem dizer esta boca é 
minha? Cuida que me há de correr as esporas desd'os sovacos até as virilhas, pelo corpo inteiro, tomar conta de mim duma vez, e que eu hei de consentir? 'tá enganado 'tá muito enganado!

Sô Moraes pregou-lhe uns olhares cheios de fogo, mas no mesmo instante abrandou, e nada disse. E o Zé Tucura clamou, cada vez mais estomagado:

- Essa tiriva que 'tá aí dentro que veja que mora c'um desgraçado que engole as maiores ofensas, mudo como um peixe! Ela que veja de que ralé é o miserave' dono da casa! Sujeito que ronca que nem bugio, mas foge que nem lebre, quando vê as grandes ocasiões!

Nos olhos de sô Moraes relampeou uma faísca terrível: mas continuou quieto, a olhar aquele maluco que se esgoelava. E o Zé Tucura trepou ao mais alto da ira:

- Enjeita a briga, então, filho duma pulga?

Sô Moraes perdeu a paciência: avançou, num salto, pra beira do Zé Tucura e, antes que ele tivesse lado de puxar a garrucha, riscou-lhe a argola do relho bem na coroa da cabeça: o Zé Tucura 'frouxou, falseou o corpo e caiu pra trás; no mesmo instante sô Moraes tomoulhe a arma e cantou o relho em cima daquele corpo estendido. Foi um chuveiro de guascadas, cada qual mais de sustância e deixando cada lanho e cada vergão que era uma tristeza! Pra baixo, mesmo perto, havia uma furna - e o som das guascadas ia formando uma ecoaria que se alastrava pelo fundão fora. Uns beneditos que estavam pinicando a perova macota do fim da rua, percuraram a linha do mato, amedrontados e falando muito.

Neste artigo a Oncinha, que estivera na porta e ficara quieta de tudo até então, gritou pra sô Moraes:

- Olhe que chega! O home' já 'tá castigado! Com mais um pouco ele é capaz de cochilar no capim!

Sô Moraes afastou-se, reparou na cara do Zé Tucura, que estava cheinha de melado da cabeça, e teve meia dó. Reparou mais atento, e viu que as meninas dos olhos do Zé Tucura tinham a proporção de duas piúnas, de tão arregaladas que ficaram; viu que nas barbas do Zé Tucura havia uma camaçada de poeira muito grande; ouviu uma sororoca um tanto engasgada, que saía por aquela garganta assim como que à força, apertando-se e espremendose, e chamou a Oncinha:

- Venha depressa, venha depressa, que o rapaz 'tá pra uma dependura: Nossa Senhora nos valha! 
A Oncinha correu ligeiro que nem uma visão, c'uma toalha de algodãozinho e uma bacia pequena, pra fazer uma lavage' nas feridas e botar-lhes um tiquinho de bálsimo e de rubim; 'garraram a cuidar do ofendido com tal carinho, que se pensava estarem ali dois irmãos tratando dum irmão; por fim, depois de postos os primeiros remédios e panos, sô Moraes pegou no referido pela cintura, amparando o corpo c'ûa mão no alto das costas, e levou-o pra casa; deitaram-no em uma esteira de piri, onde logo depois ele deu de melhorar, respirando mais livre e entre-fechando os olhos: e o barulho na casa era uma coisa que até quase que nem se percebia, tanto dos passos como das vozes em porte de segredo.

Morrer, graças a Deus o Zé Tucura não morria, estava-se vendo: mas tinha de se agüentar no balanço com tamanha brecha uma porção de dias. Os donos da casa, então, era lavage e mais lavage: ora com bálsimo, ora com rubim, ora com arnica, iam curando o outro c'um amor de admirar; despois dos curativos davam-lhe um de comer muito bem feito e gostoso: canjas de perdiz ou de nambu dos grandes, engrossados de farinha de milho com caldo de carne fresca, mingaus de mainzena e araruta, gemadas de café, e até mandaram buscar a uma botica de santa cruz uma comida nova que tem um nome esquisito, a mó' que sagu.

A sangueira perdida foi de mais, o Zé Tucura não podia sarar assim com dois arrancos: paciência e bom rejume fizeram que o cabo de duas semanas pudesse já andar seu pouco, meio encostado às paredes, até a porta da rua ou da cozinha, onde parava algumas horas, pensa-pensando na vida: viu-se desfigurado e mole que nem esses bonequinhos de engonço que vêm lá de fora, c'os olhos no fundo e uma tremedeira nas curvas.

Antes de inteirar um mês, deu-se por livre do perigo e com alma pra tratar da vida; assim mesmo inda sô Moraes aconselhou que era melhor que ele descansasse mais um bocado, não quisesse enricar da noite pro dia, trabalhasse de vagar, porque também de vagar se vai ao longe - e rematava oferecendo-lhe o minguado dinheiro que havia na casa, mas que seria dado de muito bom coração. O Zé Tucura não aceitou tantos oferecimentos, e saiu desenleado dos gestos e esperto como dante: e no dia que saiu (decerto pra festejar a sua alegria), foi a uma função entusiasmada no sítio dum tal Nicolau.

A notícia que tinha corrido era que o Zé Tucura, quando repassava um macho todo cheio de histórias, caíra p'r amór de um boleio (ora quem é que não cai, quando um burro boleia?), e por mal de pecados tomara no chatão da cabeça uns três coices: e como o caso tinha acontecido na presença de sô Moraes, sô Moraes recolheu-o e enfermou-o daquele 
feitio. Bem se vê que as coisas foram perparadas como se perpara uma cama pra um sono de regalo: sô Moraes não queria saber de prosa c'a justiça, e o Zé Tucura não havia de gostar que soubessem do quanto tinha apanhado...

Foi botar o pé na porta da casa do tal Nicolau, e ouvir um verso que o folgazão lhe atirou:

\author{
"Este verso é pra você, \\ meu querido Zé Tucura, \\ que escapou, sem mais aquela, \\ de tamanha arranhadura."
}

A moda que estavam cantando era ûa moda velha: a da Mariquinha que fugiu c'um português do sapé, que tem uma toada bonita, de fazer tristeza no coração mais arrivinido. Quando os parceiros do fandango pediram pro cantador: - mais um verso! -, o cantador saiuse logo com este:

\footnotetext{
“Zé Tucura se aprecata, pensando no sô Moraes e diz, triste e banzativo, que à praça ele não vai mais."
}

Pouca gente podia entender aquela empulhação, porque só mesmo o folgazão, fulano Bento, foi quem viu a historiada, sem contar nada a ninguém: agora, como sempre se teve por um cabra seco nos arreios, bulia c'o Zé Tucura, pra fazer graça. O Zé Tucura, se quisesse ser ajuizado, havia de ficar quieto, como quem não dá pela coisa. Mas não: irou-se, que não teve mais altura, pôs nomes feios no dito Bento, fez um banzé danado. E fulano Bento, no fim da moda, quando acabou de morrer o som da viola e o sapateado, ficou de ombro a ombro co'ele, e afiançou-lhe, alto e forte, que não aceitava uma briga barata assim.

Entrou povo no meio, apartou a dúvida, e a festa continuou. Mas porém o Zé Tucura repetia a cada instante:

- Co'este nhô Bento eu nada tenho: aquele prosa do sô Moraes é que há de me pagar! 
Pinga veio, pinga saiu, pinga voltou. A rapaziada estumava o Zé Tucura, efeito de estarem bebidos; o Zé Tucura ia-se esquentando de mais a mais: e ali por volta das quatro da madrugada, ao clarear, um terno deles montou a cavalo, covidando o Zé Tucura:

- Vamo ver, Zé Tucura, vamo ver se você é home'!

O Zé Tucura amontou também, dizendo:

- O ver é nada!

E o bando de malucos rompeu pela estrada-mestra a fora, gritando, cantando, fazendo mesmo a bulha de quem está na água. Chegaram à capela quando o sol apontava.

Ora nem que as coisas estivessem preparadas de má tenção: essa hora já sô Moraes estava de pé, junto duma guarapereva pra uma banda da casa, passando o pente na crina do seu macho de estima a assobiando sozinho e destraído. Quando sentiu aquele terno de gente que vinha quase galopeando, largou do puxar os carrapichos do burro, e olhou: inhorou muito de ver o Zé Tucura tão cedo, naquele lugar onde já não vinha há tanto tempo, mas fez como quem não tinha visto nada.

Os tais chegaram também perto do çoita-cavalo e esbarraram os animais, salvando: ele respondeu e ficou depois quieto duma vez, sem atentar em ninguém. Foi aí que o mais avariado do terno lhe falou:

- Sô Moraes, o Zé Tucura 'tá aqui pra liquidar uma conta velha com vassuncê.

- Pois eu 'tou aí, vancês 'tão vendo, às ordens de quem quiser.

Sô Moraes, neste artigo, retirou-se um pedacinho, e trouxe um embrulho debaixo do braço, mas sem explicar coisa nem uma. O Zé Tucura - verdade, verdade! - não estva lá tão disposto como tinha dito, porque decerto se lembrou de um tempo velho, um tempo que passou co’aquele sô Moraes, sabe Deus de que maneira! Mas era perciso ficar co'a cara limpa, lá isso era: chegou-se, pois, um pouco mais pra perto da árvore, puxou uma bica de dois canos e fogo central, e resmungou levantando-a:

- Agora é que é o nosso ajuste, bamo’ ver quem deve mais!

Não teve tempo de botar a garrucha no peito de sô Moraes, porque ele pulou violento que nem uma paca do mato pro carreador, e segurou-o pelo mais folgado do colete, c'um talento de força e destreza que o Zé Tucura conhecia muito bem: desamarrou mais que depressa o embrulho, abriu uma saia de mulher e desceu-a dos ombros do outro, sem trabalho nem um, até a cintura, onde puxou direito o cadarço do cós, fazendo um arrocho forte; levou depois o Zé Tucura pro largo, falando baixo e manso como quem está sonhando sonho bom: 
- Você agora vai desse jeito mas é pro cafezinho.

- Pra cadeia é que eu não vou, seo coisa-ruim.

Mas foi, e foi dali mesmo. Sô Moraes encostou-o ao cafezinho por uma embira dobrada, sem que ele pudesse dizer nada que lhe valesse, porque o povo acordado era ainda pouco, pelo arraial. Os companheiros, em vez de terem dó do coitado, pegaram a rir de longe: e uns par de beneditos, acauso com certeza! - passaram pelo ar, num vôo de muitas curvas e falando volta e meia.

Quando o inspetor do quarteirão, que era o Salvadorzinho, apareceu no largo e foi soltar o Zé Tucura, diz que o Zé Tucura estava chorando feito uma criança: explicou ele que era de fúria, mas afinal ninguém não acerditou. Saiu dali tal e qual o boi quando sai do picador, enveredou pela estrada do panema, e diz que se atirou pro rio, de desesperado da vida: mas ninguém não acreditou, porque veio logo notícia que ele andava lá por Nioac ${ }^{77}$, junto c'os Dinizes, fazendo uma boa vida, por sinal.

Pois assim mesmo ainda mandou fazer uma carta pra Oncinha, daquela distância! A carta era, a bem dizer, uma choraria sem proporção. A Oncinha recebeu-a por volta das dez horas, quando batia umas roupas, na fonte, e quem teve ordem de a ler foi o próprio sô Moraes. A moça estava cantando, na toada da cirandinha, um verso velho de catira:

\section{"Como veve quem não veve junto com quem quer viver!"}

Acabou de ouvir ler a carta, fez uma ombreira, levantou uma peça de roupa pro ar, e acabou de cantar o verso:

\footnotetext{
“" tá que nem o peixe em terra saluçando pra morrer."
}

\footnotetext{
${ }^{77}$ Nota da edição: Segundo FERREIRA, Aurélio Buarque de Holanda. Op. cit., p. 1194, Nioaque é uma cidade que fica no estado de Mato Grosso do Sul e o indivíduo que é natural de lá é conhecido como nioaquense.
} 


\section{Análise do conto}

"Forte teima!" É um representante dos cinco contos "estilisticamente imaturos" sentido dos regionalismos nele não serem bem dosados e o falar caipira não se adequar ao caso narrado, segundo a estudiosa de Valdomiro Silveira. Os outros quatro contos "estilisticamente imaturos" são: "Castigo do céu”, "Bocó-de-mola", "Soneira brava" e "Reis".

O tema do conto é a violência, materializada na forma de uma briga entre duas personagens masculinas, Zé Tucura e sô Moraes, tendo como pivô, a mulher desejada, Oncinha.

Podemos afirmar que o discurso do narrador é mesclado: traz elementos tanto do português erudito quanto do falar caboclo. Um exemplo ilustrativo disso é o trecho abaixo:

"Sô Moraes até que não era tocado a valentão: vivia de seus ganchos, pra um lado e pra outro, comprando café no sítio de nhô Tino pra vender na casa do Gervásio, barganhando um tordilho por um baio, recebendo dinheiro aqui pra mandar pra são paulo, enfim fazendo seus arranjos caladinho e sem mexer co'a vida dos mais".

No trecho acima, encontramos algumas expressões bem regionais, tais como "tocado a valentão" e "sem mexer co'a vida dos mais". Convivendo com elas, algumas palavras eruditas como "barganhando" e "arranjos". Essa mistura de expressões e vocábulos denota experimentalismo lingüístico por parte do narrador-autor. Além disso, a criação musical, na cultura popular se faz ver.

No conto aparecem muitos arcaísmos. Alguns deles são: "aprofiava", "arrodeasse", "sociadade", "percisava", "nuve", "amolentado", entre outros.

\footnotetext{
${ }^{78}$ DIAS, Carmen Lydia de Souza. Op. cit., p. 195.
} 


\section{Os guaxes ${ }^{79} 80$}

Naquele tempo o laranjal da Serrinha não estava no ermo, como agora, que não vale uma pitada de rapé: tinha bem boa casa de morada pra uma banda, perto d'água, criação grande, e dali a pedaço, longe umas cem braças da casa, a gente via a roça de cinco alqueires, onde os milhos já embonecravam, prometendo uma colheita e tanto. O ano era de fartura, lá isso era, em todas as coisas, até nos próprios arvoredos do mato.

Foi situante no lugar um tal Chico Marzulão, sojeito estimado e bem visto dos vizinhos, casado c'ûa mulher das melhores deste sertão, não desfazendo nas outras. Mas o merecimento de mais porte que seu Chico tinha, pra dizer uma certeza certa, era ser pai da moça mais chibante que se tem conhecido até hoje por aqui em roda. Nhá Lina se chamava aquele anjo, segundo o esquisito apelido que lhe botou o Reimundo, que lhe queria tanto como a sombra quer ao sol: porque, afinal, onde é que já se viu heresia assim, dar nome de morador de céu pra uma criatura do mundo dos pecadores?

O Reimundo, que sempre foi um ventana pra vida, trabalhador que nem alimal (com perdão da palavra), ficou embeiçado por ela, desde que a viu uma tarde, passando por ali e pedindo por acauso uma xicra de café: ela, nhá Lina, trouxe o café em pessoa, enquanto a mãe o hospedava, proseando co'ele, e o Reimundo sentiu-se logo quente das orelhas, e de olhos turvos como quem firma a vista em qualquer luz muito forte. Ela era destrocida, não se avexava a dois arrancos: veio lá de fora, onde as mulheres são desembaraçadas como quê, e também entrava direito na conversa, até rindo, quando chegava a casião.

Daí por diante, já se sabe, o Reimundo 'garrou por ela um rabicho em demasiado: ê! rabicho! Cortava na subida e na descida, e dava só aquelas ânsias! Percurou saber quem era a moça, o pai e a mãe da moça: colheu logo que o pai foi sempre dos que não admitem que ninguém lhe pisasse no ponche; e a mãe, de respeito a conta inteira. Morava lá pros fundos da Pedra Branca, e pegou a tecer pela Serrinha, fazendo como quem vinha pra vila, voltando quaji em seguida, feito um andante de costume.

A princípio nhá Lina pouca atenção pôs no rapaz: mourejando todo o santo dia, ela não tinha um pequeno tempo de seu pra bispar as pessoas que mexiam pela estrada; despois,

\footnotetext{
${ }^{79}$ Nota CLSD: “O Estado de S.Paulo. São Paulo, 15 de abr., 1902. (Escrito por Casa Branca)".

${ }^{80}$ Nota da edição: O conto possui versões nas pastas Mucufos e Originaes manuscriptos de Papae (preciocíssimos).
} 
por ele às vezes parar muitas horas nas proximidades da casa, c'uma espingarda troxada a tiracol, observou que tal parada devera de ser coisa: e, reparando que o tal senhor dão era bem parecido, pensou o que pensam as da mesma idade que ela, até agora, e foi ficando triste, como reza a história, até reconhecer consigo mesma que se ia tornando dele de tudo. Sea Maria Rita, ûa mulher de muito tino, que sabe da vida de meio mundo pra esses centros de sítios todos, diz que é mesmo deste feitio que o diabo tenta os outros; ela, que diz, é porque tem expriência, e a expriência é a mestra da vida: remate que põe sempre em suas prosas, e é verdade.

O Reimundo achou lado de visitar a familiage de seu Chico Marzulão, com desculpa de ofrecer ûas marrãs e uns capadetes gordos: chegou à porta, preguntou pelo velho, arengaram muitas horas, pechincharam de mais, e por fim tramaram uma berganha, soltando o Reimundo dois capadetes por um poldro castanho redomão, que era uma pintura, de estampa linda, cola e crina compostas, tábua do pescoço e ancas bem feitas, escanelado, ardoroso que nem o demo. No sábado que veio, trouxe os porcos, tomou um café, mais um isto, mais um aquilo, e foi-se embora no romper da lua, levando o cavalo adestro, e sentindo o rumor louco do coração dentro do peito.

Passados meses, negócio vai, negócio vem, deu um vomitório pra mãe da namorada, afim de ver se saía ou não o casamento: a velha remancheou, gaguejou, fez mesuras, fez rodeios, e ele contemplou-se despachado. Tem daqui, tem dali, achou de talho a nhá Lina, um dia, e falou-lhe de vereda se queria ser a companheira dele: a nhá Lina arrespondeu que sim, que queria, - era só pedir pro pai.

E agora.

Topou no outro dia com o Chico perto do monjolo, trançou as pernas em riba do selim, que a égua sabina em que estava montado era um cachorro, de mansa, e conduziu o intento da conbersação até fazer o pedido. Seu Chico pode-se dizer que enfiou. Não: enfiar, não enfiou, mas embatucou, que é quaji, tanto faz dá na cabeça, como na cabeça dá.

Vira, mexe, vira, mexe, acabou seu Chico por explicar que decerto não cabia a proposta, não havia arrumação, porque a moça era de santo, por uma promessa que ele Marzulão e a dona fizeram, duma intendência que ela, menina ainda, se achou às portas da morte, por via dum sarampo arrenegado.

E quem é de santo, não hai quem não saiba, tem sempre desastre na vida, e morre por desastre. 
O Reimundo, nem bem seo Chico lhe deu adeus, chegou os garfos à catirina, e saiu ventando pela estrada a fora, c'uma zunideira nos ouvidos e um peso na cabeça, que até mostravam jeito de doença. Arrebentou na vila, quando menos esperava, navegou que nem um mantecato pelas ruas, sem apear em parte alguma, e fez chão pelo escurecer, aborrido, já sem altura.

Mas daí a uns par de dias, pilhando outra vez a nhá Lina de talho, foi-lhe fazendo suas queixas e exclamações: e a nhá Lina, que pissuía um coração mole e vivia pendurado dos olhos dele, jurou, no fim de contas, que havia de ter toda a firmeza; e pediu-lhe que a esperasse, com firmeza por igual, porque a gente deve de acreditar piamente no ditado: não hai bem que sempre ature, nem mal que nunca se acabe.

Sea Maria Rita não é à toa que dá a entender que os namorados, quando chegam a este ponto, vão descendo, descendo, de tentação em tentação, até ficaram c'um pé na terra e outro no inferno. Mas qual, seo Maria! Inferno é aqui mesmo na terra: pois vassuncê quer maior pena e mais grande sofrimento que estar um pobre coitado c'a boca n'água e morrendo à sede, ver uma canoa?

O partido conservador estava de cima, e o seo Chico Marzulão era um chimango peitudo. Os liberais cá do mato arreceberam cartas lá de baixo contando por notícia que mais mês menos mês, o imperador ia chamá-los pro poder: de maneiras que as eleições desse tempo iam ser brabas.

Assim que elas foram vesprando, o afamado Chico Dia mandou avisar aos daqui que havia de trazer um ajutório que servisse direito; Marzulão, que era colega do Chico Dia, meio irmão de criação dele, até, ficou entusiasmado, que gaguejava e chorava quando vnha de jeito falar-se na subida dos seus. E chegou muitas vezes a bufar, inchando o papo que nem um arurá assanhado.

- Deixe correr o aço, que esses saquaremas hão de ver de que pau é a canoa, quando eu tiver voz ativa e for sobdelegado aqui no distrito! Esses danados cuidam que batuque é reza, imaginam que marimbau é gaita. Eles hão de encontrar forma pro pé!

Veio o falado dia. Regulando seis da manhã, ou pouco mais, a gente do Chico Dia passou pelo alto das três ilhas. Cada qual dos caboclos trazia bandeirinha branca nûa mão e bacamarte na outra, e garrucha dum lado da cintura, e faca do outro lado, - e caminhavam alegres, numa pagodeira. O Chico Dia, amontado num saino de oito pés, ia na frente do povo: 
e se porventura o saino queria descair na balança, relava-lhe no sofragante as chilenas pras paletas que era um regalo.

Seo Chico Marzulão, já de conchavo antigo, perparara a matula de noite, porque era vindouro na terra e não tinha casa pra assistir no povoado. Ao clarear, arreou seu macho, esperto que era um raio, e foi-se encontrar co'a caboclada do Chico Dia na volta do caminho. No instante em que rompeu juntico deles, como por um milagre, todo o povaréu gritou que parecia uma demência:

- Aí, companheiro sacudido! C'uma parceirada em que tenha muitos desse calibre é que os cascudos verão bóia! Viva o Marzulão! Fogo no Marzulão!

E umas par de garruchas afloresceram de pólvora queimada, arriba das cabeças de todos. Aquilo eram salvas ao seo Chico e aviso à liberalada da vila: ouvidos os tiros, passada a primeira impressão, houve um reboliço pras ruas, que não acabava mais, e só asserenou quando apareceu no alto, pra lá da igreja, aquele mundão de gente.

Êta! Eleições brabas! Até hoje são faladas!

Ora por essa casião as laranjas estavam que era uma calda, muito maduras e muito doces. E no laranjal da Serrinha, pegado c’o quintal de seo Chico Marzulão, juntava uma guaxaria que nem se podia contar. Mal e malzinho que apontava o sol, já se ouviam pela capoeirama a fora os pios chupados e o rumor das asas de semelhantes pass'os.

O Reimundo, logo que viu seo Chico passar o morro que ia acabar na estrada real, veio devagar, encarapitado em sua sabina, c'o coração bate-que-bate, pedir pra nhá Supriana, mulher do dito cujo, licença pra espichar fogo nos guaxes, que na certeza andavam gordos e magníficos pra um arroz com tranqueira. Nhá Supriana, foi ele pedir, foi dar a licença: e o freguês torou de rumo pro laranjal, que era aí adiante, pra baixo, na virada do morrinho lançante que verte pro córgo.

Daí a pouco os tiros principiaram, um em cima do outro, que não paravam mais: a mó' que a troxada só descansava enquanto ele puxava os aviamentos da mucuta e enchia os dois canos. Nhá Supriana, ouvindo tamanho barulhão, assustada a mais não poder, poribiu dois crioulinhos, que brincavam no terreiro, de irem pra aquela direção: e encafuou-se no quarto, serzindo ûas meias de algodão, sossegada já, por pensar que nhá Lina andava pra cozinha, lidando co'as panelas, e não corria risco nem um.

Nhá Supriana, em seu trabalho, dava de cantar a vida inteira. Naquele dia como nos outros, enquanto a agulha ia e vinha dum pedaço de algodão pra outro, saíam da boca da dona 
aquelas modinhas cheias de saudade, aquelas modinhas que aprendeu quando era frangota ainda, cobiçada de um bandão de moços e amante já de seu Chico Marzulão, que ao mesmo tempo gostava dela, que era um desespero. A agulha ia e vinha, o pensamento de nhá Supriana também ia e vinha: às vezes o pensamento andava mais depressa, outras vezes era a agulha, e a tarde estava caindo, sem barulho, vagarenta.

Houve uma hora, apesar de tudo, em que nhá Supriana se lembrou do mundo.

Prestou atenção pro rumo da cozinha, não sentiu nhá Lina lidar mais; pegou a escutar na linha do laranjal, não percebeu mais tiro nem um. Levantou-se, chegou à cozinha: nada de nhá Lina; campeou p'r a casa inteira, nada. E ficou de repente tomada dum susto: que estes caçadores, Nossa Senhora da Penha, chegam a pôr chumbo numa caça mesmo em frente dos outros.

Mas assim que apareceu na janela do quintal: que gritou por nhá Lina, que nhá Lina arrespondeu e veio quaji correndo; assim que viu, pra um recanto do rocio, passar o Reimundo meio arcado, com feitio de escondimento, no instantinho em que um coitelo riscava chita c'as asas abertas no meio da varanda: nhá Supriana achou-se mais assustada, à toa, a bem dizer, mas tremendo tal e qual um passarinho meio chamuscado.

Não disse nada pra nhá Lina, entrou pra dentro do quarto, e fez um choro largo e muito delorido, em silêncio, como quem purga pecado. No meio do choro, entretanto, lembrava-se do que fora no tempo de solteira, do juízo que tivera, e o pensamento do passado ia e vinha, como poucas horas antes, que nem a agulha de um pedaço de algodão pro outro pedaço. Chorou, que foi uma loucura: e assim que seo Chico voltou, já sobre a noite, encantado c'as eleições, nhá Supriana lhe falou perto da orelha, c'os beiços frios e os olhos queimando:

- Olhe, seu Chico, o primeiro desastre já foi, agora espere pro outro!

E contou-lhe o que assucedera.

Quem tinha razão era sea Maria Rita: quando os namorados chegaram a certo ponto...

Pois não aconteceu o segundo desastre. Seu padre vigário botou a bênção de casamento nos dois, num dia despois da missa, apesar que moça de santo deve de ser de santo toda a vida. Quando a comitiva dobrou a aguinhadas pedras, já perto da casa, no fundo do laranjal, e um casal de guaxes passou pelo ar, gritando, que não tinha mais jeito, o Reimundo falou pra nhá Lina, em segredo:

- Aquilo é que é pass'o bom, nhá Lina! 
Ela ficou sem dizer nada. Ficou, mas em compensação, pôs-se vermelha como um juá manso, na roçada, assim que o guatambu, sem dó, foi descobrir as ervas mais altas e também o descobriu.

Coisas que a gente vê neste guanhã de mundo! 


\section{Análise do conto}

"Os guaxes" é um conto com pouquíssimos diálogos. Os regionalismos não estão bem dosados e o falar caipira não se mostrou adequado. Pode ser considerado apenas como repositório do caso para futura reelaboração. É um conto experimental onde ocorre uma mistura acentuada entre coloquialismo culto e coloquialismo sertanejo. Um bom exemplo dessa mistura é a passagem abaixo:

"Naquele tempo o laranjal da Serrinha não estava no ermo, como agora, que não vale uma pitada de rapé: tinha bem boa casa de morada pra uma banda, perto d'água, criação grande, e dali a pedaço, longe umas cem braças da casa, a gente via a roça de cinco alqueires, onde os milhos já embonecravam, prometendo uma colheita e tanto. $\mathrm{O}$ ano era de fartura, lá isso era, em todas as coisas, até nos próprios arvoredos do mato."

Como exemplos de coloquialismo culto no trecho acima, podemos citar as seguintes expressões: "não estava no ermo" e "a gente via a roça de cinco alqueires". Exemplos de coloquialismo sertanejo: "não vale uma pitada de rapé" e "boa casa de morada pra uma banda".

O tema do conto é a marca do preconceito e a rigidez dos preceitos morais que cercam a mulher, no mundo caipira. 


\section{Na rua do Bosque ${ }^{81}$}

Já se chamou do pito aceso aquela rua, e não foi à toa! Nunca se viu recanto de cidade onde houvesse gente mais levada das carepas, que ali. Aos domingos e dias santos, nem bem o folgazão do sol dava de iluminar a barra do céu, já por lá se reunia um povão de caboclos, que nem formiga, virando para um lado e para outro, dizendo lérias às tiribas que não faltavam naqueles cochicholos empinhocados, pintando a saracura. De tudo se via então: namoros descabelados com umas certas mocinhas que já estavam entre a igreja verdadeira e a igreja verde; cumprimentos rasgados de uns tais a umas tais, que todas se requebravam, no corpo e nos olhos, e até, para que se representasse também o trágico, muitas vezes a boca esguia de uma facada golfava sangue aos borbotões pela areia, ou desabrochava de uma garrucha, que dantes ninguém tinha visto, a flor amarela e fumacenta de um tiro.

Navegava pelo bairro, sempre roncando valentia e pisando no ponche dos mais, um fulano Bernardes, que era homem de más entranhas, a julgar-se pelo que fazia, pelo que prometia e, principalmente, pela fulva expressão de ódio que lhe reviam os olhos, onde quer que os fitasse: fulva se lhe tornava ela, ainda mais, porque os seus cabelos louros, anelados em voltas longas, desciam-lhe até a meio da testa, emaranhados e revoltos. A voz era-lhe quase um rugido, tanto se avezara a falar por monossílabos aquele demônio desguaritado, ao que então se dizia, de uma biboca qualquer do Rio Pardo, em que não havia com quem armar uma briga que valesse a pena do esforço.

Ganharam-lhe medo os freqüentadores da rua. Quando o viam de longe, tratavam de evitá-lo com cuidado, com maoir cuidado ainda em razão dos melindres que mostrava, pois era corrente que uma vez, como um mineiro lhe fugisse, entrando de sopetão em casa da moça que assistia perto do espraiado, ele tirou-o à força lá de dentro, sacudindo-o umas tantas vezes em plena rua e ensinando-lhe que um homem não deve temer-se de outro homem. Se se armava algum cateretê, e o Bernardes surgia na função, ninguém queria servir-lhe de parceiro, e fazia-se preciso que ele mesmo Bernardes saísse a campear um no meio da rapaziada.

Rosnavam que tinha feito ûa morte cá para os lados de canoas, além da divisa, e mudara de vida de repente, passando de homem de tramas a boiadeiro, deixando crescer a

\footnotetext{
${ }^{81}$ Nota CLSD: “O Estado de S. Paulo. São Paulo, 1º set., 1902”.
} 
barba, pintando o cabelo de ruivo, quase de fogo, e espontando os dentes a lima. Boca do povo!

Mas ninguém não sabia que o Bernardes se chamava Chico Romão, não tinha mulher nem famílias e era situante no Jaguari, perto do Cercadinho. Plantava sua cana, seu arroz, seu milho, e ia vendê-los ao Guaçu, com um trabalho demasiado, principalmente quando subiu o preço da pinga e o açúcar estava por empenho. Tinha tido uma soneira louca pela tal Maria Nenê, a que depois deu em droga: e como não acharam bom o casamento, em casa, foi-se ficando solteiro, pensando bem que é melhor a um triste arrastar sua vida sozinho pelo mundo, que juntar-lhe a pobre coitada dûa moça que tem todo o direito de achar quem lhe queira deveras, como ele Chico Romão quisera à Maria Nenê.

Vivia então com a mãe e a Venturosa, única irmã, linda que nem três dias de sol e mais alegre que um periquito. Afez-se àquele viver sossegado, de animal que faz sua tarefa todos os dias, do romper da madrugada ao cerrar da noite, e recolhe ao pouso, amolentado e bambo. E haviam-se-lhe fechado as aspirações, uma por uma, no âmbito estreito da lavoura, que desejava ver sempre areada e próspera, tal qual um bando de araguaris que emigra, num grasnar esperançado, para muito ao longe, e volta mais tarde, entretanto, a habitar outra vez a mata natal, donde já não anseia mais por sair porque viu lá fora o perigo, sentiu as privações, as fomes, as sedes, as invernias e o terror.

Ora, uma vez, como viajasse para Santa Cruz, a tratar um carro de bois com um conhecido antigo e se demorasse uns três dias na viagem, achoou gente de menos, na volta: e quem faltou foi a Venturosa. A mãe, com os peitos apertados pela raiva e pela dor, contou-lhe que aquilo fôra coisa-feita, ao depois que o Sarapião escrevia pelo bairro, porque desde então a moça não tivera mais sossego, acabando por fugir com ele. O Sarapião era um diabo. Deus que nos perdoe! Viera desses mundos de terras que não se conhecem, e lidava nos empreitos. Diziam que era casado, mas que largara a mulher sem mais nem menos, como quem larga um gato ou um jaguariva numa casa desamparada. Boca do povo!

Nem um barulho, nem um ameaço: o Chico Romão escutou a conversa com o coração em tropel desordenado, mas o rosto não se lhe demudou, nem a alma perdeu a compostura. Perguntou, à mãe e aos vizinhos, por onde seguira o Sarapião e a Venturosa. Ninguém podia responder ao certo, porque a fugição foi de noite, mas o rasto dos cavalos era na estrada do Cocais, caminho de Casa Branca. 
No dia seguinte o Chico Romão ensilhou o melhor cavalo que tinha, um chita veloz feito um raio, e abriu-se. Virações p'r amór da lavoura, segundo todos disseram. E ficou por isso.

Da capela para diante não teve mais notícia alguma da irmã e do outro. Em uma vendinha à beira da estrada, antes das mais casas da povoação, soube que o Sarapião (aquele jogador de vermelhinha, foi como lhe falaram) tinha passado por ali a cavalo, dias antes, trazendo engarupada ûa moça bonita e tanto, descascadinha e de olhos espertos, alegre e viva que parecia um feitiço. Não deu fé maior daquilo: fez que não se incomodava com semelhante dito, deu a entender que a nova não lhe importava. Saiu da vendinha, andou corre-correndo as últimas casas das saídas do povoado: nada mais.

Resolveu ficar de espera no bairro do Senhor Menino, andar o mais que pudesse, até um dia topar os dois fugitivos, e falava sempre consigo mesmo:

- Deixe estar, que aquele canhambora desavergonhado há de me pagar bem doído!

Chegou esse dia: transpunha a porta da igreja do Rosário, quando viu grande ajuntamento de povo nas cercanias da cadeia, em roda de dois homens que traziam, aos ombros e pendente ao comprido de um varal, um morto qualquer.

Acostumado aos solilóquios o Chico Romão pegou a perguntar de si para si:

- Que diabo de sinagoga será aquela, atromentando um defunto fresco? E esse pobre coitado que vem no catiguá, que nem uma paca, que será, quem não será?

Foi-se aproximando do grupo a ver quem era o matado (com certeza haviam feito algum crime), e a primeira fisionomia que lhe bateu na vista foi a do próprio Sarapião, um dos carregadores do corpo, que ia meio penso, de cansado, e suando em bica.

Começou o Chico Romão a tremer, a tremer, e por um triz não o agarrou logo ali, cheio de fúria, como um demente. Mas teve mão em si, esperou que todo o reboliço esmorecesse, o auto fosse lavrado, e mais tarde, assim que o Sarapião deu de ir embora, o foi acompanhando de longe, com toda a cautela, fingindo um passeio à toa.

O Sarapião caminhou pouco: enveredou para a esquina do urias, passou a casa do capitão Vicente, afundou-se na rua da Estalage. Quando chegou a uma casa pequenina, de janela de rótula, e bateu, quem lhe apareceu foi a Venturosa, já no meio desfeita a cabo de tão poucos dias, com os olhos empapuçados de choro e os cabelos despenteados. O Chico Romão bem que sentiu piedade, bem que teve ímpetos de voar à irmã, arrancá-la de tão triste morada: 
mas lembrou-se da traição que lhe fizeram, conteve-se. Também o Sarapião não esquentou lugar na casa, rompeu logo.

Caminhava agora para o lado do cemitério, o Chico Romão seguia-o de longe; endireitou no rumo da igrejinha da Boa Morte, o Chico Romão lá ia feito uma sombra; fez direção para a rua do Bosque, o Chico Romão não torceu nem uma linha. Entrou numa casa, fechou a porta: e o silêncio da rua, quebrado a essa hora apenas pelo áspero ranger daquela porta preguiçosa, reatou-se de novo, como uma grande tristeza de desamparo e de ruína. $\mathrm{O}$ Chico Romão olhou demoradamente para aquela casa quieta, querendo adivinhar o que passava dentro, e depois, a afastar-se, murmurava escumando de raiva:

- Antão é aí que você mora, roubador de moça? Eu hei de lhe mostrar como é que o urutu se vinga de quem um dia pisou na cacunda dele. Espere só!

O Sarapião não teve que esperar muito tempo.

Era num dia primeiro do ano. A caipirada repontara dos sítios, desde pela manhãzinha, e a cidade estava dura. Havia uma congada como nunca, de creoulos entusiasmados e cantadores loucos de bons. Assim que rompeu a alvorada, já se ouviu a cantoria que vinha descendo da estação, arrastada e lângüida:

"Senhor rei, bamos embora,

ai!

Senhor rei, vamos embora!"

Cada congo era um brinco. Aparecia um, vestido de cetim e todo cheio de fitas, que puxava a dança; quando proferia as últimas palavras do verso e agitava desabaladamente o adufe $^{82}$, viam-se-lhe encher os olhos de água e a boca tremer convulsa, de pura comoção. Outro, que todos contavam ter fugido de uma fazenda do norte e era o melhor pulador do bando, não dava uma volta sem olhar para todos os lados, com os olhos sempre possuídos do susto selvagem. E um se notava entre os mais corpulentos e reforçado, que cantava com soberana soberbia, passando a todo instante a mão enorme sobre as plumas que lhe arfavam festivamente na cabeça. O rei congo era um velho: ficava já quase imóvel entre os companheiros, pensativo e cansado, talvez a cismar que em breve a coroa teria de passar a

\footnotetext{
${ }^{82}$ Nota da edição: Segundo FERREIRA, Aurélio Buarque de Holanda. Op. cit., p. 50, adufe também pode ser considerado um brasileirismo com o sentido de um "antigo pandeiro quadrado, de madeira, com dois tampos de pergaminho, que encerram fieiras de soalhas".
} 
outro, a um outro que ali estava, de olhar muito audaz a romper de um rosto esguio, e que, como é costume entre os príncipes herdeiros, em todos os reinos, já mostrava sua ambição e sua valentia nas mais pequenas conversas.

Quando a congada chegou à rua do Bosque, não houve mais passagem para uma criança que fosse: a grama das beiradas das casas ficou amassadinha? A bica por onde vinha a água da chácara do capitão Vicente sumiu no meio do povo. A mulher do Sarapião, que era uma paranista bonitona, estava à porta da casa e olhava a congada, junto do marido e dos filhos: e todos tão entretidos, que ninguém viu a hora em que o Bernardes chegou a cavalo, sabe Deus como! - em frente àquele povo. Logo que reconheceram, ficou a cangada quieta, como por um milagre, e foi só o negralhão soberbo quem se afrontou a dizer:

- Bamo’ co’isso, que aqui não aconteceu nada!

Mas o Bernardes não tinha que ver com aquele prosa. Olhou-o, sacudiu os ombros. Aproximou-se da porta do Sarapião, mirou-o e remirou-o bem, perguntou-lhe sufocado:

- Você me conhece, Sarapião? Não conhece, eu bem 'tou vendo! Pois olhe: eu sou o Chico Romão, aquele do Cercadinho, o irmão da Venturosa, que você tirou da casa da mãe e ponhou nûa meiágua, lá pra esses fundos. Conhece agora?

O Sarapião não respondia. E o Bernardes tomou-o pelo peito, falando rouco:

- Quem deve paga, Sarapião. Você paga hoje a conta velha. Como você não presta, eu 'tou sentindo, é a sua mulher que fecha as contas.

Aferrou a mulher do Sarapião pelos braços, com uma força sobre-humana. Nada valeram gritos e queixas, de nada serviu a defesa frouxa daqueles braços que se enfraqueciam pelo terror. Não houve quem punisse por ela, nem quem dissesse coisa com coisa.

O Bernardes correu as esporas no chita, saiu pausado e rindo-se. Quando se alongava, quando torcia a esquina que vai ao largo da boa morte, ouviu uma palavra dolorida e raiventa:

- Ai! A minha mulher é tão de bem, meu Deus de misericórdia!

Entreparou, voltou-se:

- A minha irmã também era boa, desgracionado! 


\title{
Análise do conto
}

"Na rua do Bosque" tematiza as manifestações do folclore e da cultura popular (no caso, uma cantoria e um congado) e o poder ligado à política que, no sertão, se traduz em coronelismo. O enredo trata da fuga de Venturosa, com seu amado, Sarapião, e a perseguição aos fugitivos por parte do irmão da moça, o Bernardes, ocorrida durante os festejos do Ano Novo.

"Era num dia primeiro do ano. A caipirada repontara dos sítios, desde pela manhãzinha, e a cidade estava dura. Havia uma congada como nunca, de creoulos entusiasmados e cantadores loucos de bons".

O coronelismo tinha na figura de Bernardes (que mais adiante ficamos sabendo que se chamava Chico Romão) sua máxima expressão:

\begin{abstract}
"Navegava pelo bairro, sempre roncando valentia e pisando no ponche dos mais, um fulano Bernardes, que era homem de más entranhas, a julgar-se pelo que fazia, pelo que prometia e, principalmente pela fulva expressão de ódio que the reviam os olhos, onde quer que os fitasse: fulva se the tornava ela, ainda mais, porque os seus cabelos louros, anelados em voltas longas, desciam-lhe até a meio da testa, emaranhados e revoltos".
\end{abstract}

O conto apresenta uma combinação de linguagens: a coloquial culta com a coloquial sertaneja. Essa combinação tem como resultado "um discurso mais ou menos homogêneo",83 que coloca no mesmo nível o discurso do narrador com o das personagens, através da suavização de alguns aspectos linguísticos característicos das falas culta e rústica. É o que podemos observar no discurso do narrador, abaixo transcrito:

"Já se chamou do pito aceso aquela rua, e não foi à toa! Nunca se viu recanto de cidade onde houvesse gente mais levada das carepas, que ali. Aos domingos e dias santos, nem bem o folgazão do sol dava de iluminar a barra do céu, já por lá se reunia um povão de caboclos, que nem formiga,virando para um lado e para outro, dizendo lérias às tiribas que não faltavam naqueles cochicholos empinhocados, pintando a saracura".

${ }^{83}$ DIAS, Carmen Lydia de Souza. Op. cit., p. 185. 
Podemos notar a homogeneidade das linguagens culta e rústica através do uso de construções sintáticas ligadas ao campo do erudito ("nem bem o folgazão do sol dava de iluminar a barra do céu" e "para que se representasse também o trágico") e expressões regionalistas ("levada das carepas", "dizendo lérias às tiribas" e "pintando a saracura”).

Quanto aos arcaísmos, o conto apresenta vários, tais como: "cochicholos", "desguaritado", "situante", "amolentado", "demudou" e "fugição". 


\section{$\underline{\text { Paixão de raiz }}^{8485}$}

- Aquilo é que era mulher (dizia o Agostinho, do Mandaguari): nem bem o dia clareava, já lá ia pro terreiro tratar das galinhas e do resto da criação. Dormia comigo na cama, e amanhecia c'os porcos no chiqueiro! Muitas vezes, quando eu acordava, e o sol ainda se via a uma altura pequena, já o café 'tava pronto, a casa varrida e o feijão no fogo. Aquilo é que era mulher!

Foi realmente grande perda, a morte de nhá Gertrude: quem a conheceu, há de até hoje repetir que era de dar tristeza um acontecimento assim. Apesar de terem já passado uns três anos, o pessoal do Mandaguari ainda a pranteava. Nhá Gertrude deixou umas quatro dúzias de comadres esparramadas pelo mundo: umas que a procuravam meio às escondidas, pra lhe pedirem que batizasse o pobre dum anjinho que não tinha pai; outras, que mandavam os filhos já viçosos à casa dela dizer que a queriam por madrinha: outras, afinal, que propunham no meio duma conversa, como se visse por acaso de talho:

- E não é que nhá Gertrude bem podia levar o meu caçula pra pia?

Ora se levava, isso nem havia dúvida! Pois porque é que não havia então de levar? Uma coisa tão fácil que nem mudar uma palha! E as mães das crianças ficavam muito satisfeitas, muito alegres: esta nhá Gertrude era deveras uma alma de santa! No seu coração batia decerto um pouquinho do coração de Nossa Senhora!

E pra dar esmolas? Parece que trabalhava só pro gosto de no domingo repartir as economias com os pobres que viajavam pelo sítio. Até aí por volta das duas da tarde, quem chegasse ia servido dalgum dinheiro, tão certo como três e dois serem cinco. Depois, o cobre ficava vasqueiro e por fim sumia, que ela também não era uma ricaça. Mas nunca foi capaz de cantar pra um pedinte: - Vá-se com Deus , agora não se tem! - Nunca! Dava-lhe então de comer, dava-lhe qualquer peça de roupa, dava-lhe quitandas, dava-lhe caninha. Ninguém saía descontente.

Boca abençoada era a da nhá Gertrude. Não falava da vida alheia, quando a murmuração era coisa bem correntia até, nos costumes da vizinhança! Se estavam tosando

\footnotetext{
${ }^{84}$ Nota CLSD: "Escrito em Casa Branca em 1902".

${ }^{85}$ Nota da edição: O manuscrito possui versões nas pastas Mucufos e Originaes manuscriptos de Papae (preciosíssimos).
} 
uma pessoa ausente, ela barganhava de conversa tão logo, que os maldizentes estuporavam de vexame. Morder na honra das famílias foi malvadez que nunca ninguém conseguiu perto dela, porque, se principiava o nhe-nhe-nhe, no mesmo instante ela recordava: - Olhe, seu fulano, que vancê tem mulher e tem filhas! Ninguém 'tá livre dûa mal-falada! - E o tal sujeito ficava na embatucação.

Pois bem: morreu... Está morta: o que se há de fazer? Quem pode tudo assim determinou: resta que a gente se conforme com as vontades de quem pode tudo, principalmente porque não há outro caminho a seguir. Pra que tamanhas lamentações, agora? Diz que o chorar alivia, e é certo, mas o queixar-se e o lamuriar é que não adianta nada. Que rumor então era esse que o Agostinho andava levantando, volta e meia, com dizer que aquilo é que era mulher? Glória a Deus nas alturas, e paz aos homens e às mulheres que estão na terra e debaixo da terra! Por estas falas, mais ou menos, é que o Rodrigo aplacava as choradeiras do Agostinho, todo santo dia.

E o Agostinho não arredava pé daquele triste costume. Se lhe contavam que a porca de um tal tinha parido tantos leitões, que eram muito bonitos, ele recordava que nhá Gertrude, pra cuidar duma barrigada de leitões, estava sozinha; se lhe noticiavam que a peste de gogo deu na galinha carijó da filha mais moça, ele suspirava, dizendo, ato contínuo, que em vida de sua defunta mulher nunca tinha acontecido isso no galinheiro do sítio, onde os cochos de pausanto viviam então sempre cheinhos d'água; se via passar a égua lobuna, lembrava-se na mesma hora de nhá Gertrude (não haja trocas de sentido!), porque nhá Gertrude, quando montava na supradita égua, estava satisfeita que nem uma santa no altar, ainda que semelhança seja meia hereje. A égua saía numa guinilha miúda e muito engraçada e nhá Gertrude ia só cambeando o corpo em riba dela! Ai! Tempo, tempo que não havia de voltar mais!

Não lhe dissessem que dona Sicrana era boa, que dona Beltrana era decidida, porque no mesmo repente ele contestava:

- Qual história! Qual nada! Como nhá Gertrude nunca há de vir outra a este vale de lágrimas!

E pra provar que este vale de lágrimas é realmente de lágrimas, um punhado delas corria devagar e devagarzinho por aquelas rugas compridas, que se tinham formado em continuação das olheiras; passava a cacunda da mão direita pra enxugar a água amarga, e 
fincava o olhar em qualquer ponto da casa, como se estivesse querendo ver uma coisa que ninguém via, com ânsia ecom desespero.

Mas apareceu-lhe um casamento. E quem não havia de ser a noiva? - a filha mais cresçuda do próprio Rodrigo, uma chibantona e tanto, que dava sota e basto nas funções daquele pedaço de mundo. O Rodrigo, quando lhe praticou em tal assunto, foi logo explicando as coisas tim-tim por tim-tim, dando o nome aos bois, como dizia:

- Você, seo Agostinho, já não é criança, isso é verdade. Com certeza já anda nos corenta e cinco, pra mais, que não pra menos. Mas isto não osta: a Malvina também já não 'tá mais nos cueiros, é coisinha mais nova que a Antonia, e a Antonia, por ser simple, como você sabe, não se pôde arranjar até agora, com vinte e oito que já tem. Pra você viver sozinho neste canto, 'tá aí o que não dá certo: um home, seja como for, percisa sempre duma companheira, e companheira de virar e romper. Se você entender que a Malvina lhe serve, eu não contrario o casamento.

Fez-se tudo em pouco tempo: o Agostinho foi-se acostumando a olhar pra noiva com bons olhos, reparando-lhe nos modos desempenados e na prosa larga, e muito mais em certo luxinho que a moça fazia nas sobrancelhas, quando parecia duvidar do que se lhe afirmava. Era uma tentação! Depois, arrumadeira da vida: sabia moquear um peixe como ninguém, serzir com todo o cuidado a meia mais puída, cortar e costurar, dar o melhor ponto a um arroz, plantar e quebrar um milho com destreza, e até (ninguém nunca o tinha visto, mas era coisa afirmada de certeza pelo Agostinho) fazia rendas entusiasmadas, como essas que os turcos vendem com faixas de papel vermelho.

Moveu-se o bairro em peso, pra assistir ao casamento. Foram chamadas umas moças dos Campos, as mais cumbas que havia no sertão pra dança da quadrilha, que não se sabia por estes mambembes; veio o sanfonista melhor que morava na vila, pra tocar a música da tal dança; apareceu a rapaziada mais afiada pro fandango, e cada violeiro levado do sarro; não faltou a negraria que esquenta os sambas por perto da Ilha Grande, e o maior tocador de caixa dos arredores, o João Velho: e até, pra ficar tudo completo, mexeram da Onça uns homens que inventaram agora um folguedo diferente, muito vagaroso e esquisito, a dança do corvo.

Lugar houvesse pra tanto povo! As moças dos campos de par a par c'uns rapazinhos engravatados que também surgiram como por maravilha, encheram os olhos da gente da casa e do bairro: dançaram depois umas rodadas, coisa de admirar! Um cantador do Capivara, que pegava no pinho com maneiras muito macias, encarreou nada menos que uma dúzia de modas 
desconhecidas; cantou algumas pelengas sentado, fez o que quis da viola e da caipirada, passarandagens difíceis, cada sorte de assustar: ponteava que era um encanto, e chegou a apresentar certos toques que nunca se tinham ouvido, com batido de papilotes na caixa do instrumento e voz ensurdecida de cordas.

Não faltou nada bom na festança. O Rodrigo, que era um sujeito de melúria, jeitoso como ele só, teve artes de justar um doutor na vila, pra fazer um discurso: e veio o doutor, e fez um discurso bem arranjado, gabando o mais que podia o noivo e a noiva, falando em felicidades e flores, palavras muito bonitas e que caíram muito direito naquela ocasião. $\mathrm{O}$ coreto que se cantou depois do discurso, esse então nem se fale! - foi de arripiar os cabelos: o Agostinho, que é um homem de coração maneiro, como ele mesmo sempre conta, ficou até c'os olhos cheios d'água.

A noiva estava numa puba em demasia: tinha vestido cor de rosa (diz que as noivas agora não precisam mais trazer vestido branco), uma capela grande de flores de laranjeira, tanto das que vêm da loja como das apanhadas no pomar, uns brincos de ouro e lequinho de penas também cor de rosa mais claro, sapatos de cetim, cheios de histórias... Uma boniteza!

O Agostinho, pra dizer que estava muito senhor dom, não estava: mas encomendou roupas novas, botou-se todo na estica, de barba aparada e cabelo repartido no meio, c'um par de botinas que alumiava, e, no peito da camisa, dois botões de brilhantes tão grandes, que pareciam aquelas últimas estrelas que se apagam quando o dia vem rompendo.

Chegou a hora dos noivos se acomodarem. Mas muito tempo, ainda muito tempo, enquanto não clareou, o sapateado do fandango e o rufo louco da caixa bateu sem parar e em cheio nas covancas e arrastou-se bem longe pelo embromado escuro das capoeiras.

O Agostinho não esperou, na casa do sogro, que passassem os três dias de hospedagem. Mandou logo cedo arrear a tropa. A neblina era grande, mas viu-se, daí a um pouco, o primeiro raio de sol, como uma fina lança de fogo, atravessar a cerração: e ouvia-se ainda a moda última do João Velho, na roda do samba, quando se levantou na estrada o rumor da ferragem dos animais em marcha.

Ia a Malvina montada num baio açafranado, um cavalinho marchador e faceiro, manso como um cachorro e engraçado no pisar como não se achava outro na comitiva.

A par c'o Agostinho caminhava um fulano Lope, seu compadre e amigo desde moço, que lhe falava bem da Malvina e ao mesmo tempo lembrava as boas qualidades da defunta Gertrude: 
- Coiração delicado 'tava ali, não hai dúvida mas contanto que sá Malvina também é ûa moça às direitas. Já se vê que você que você tirou duas vezes a sorte grande!

Depois, como dobrassem o espigão e o pendente da outra banda fosse mais forte, agarrou o baio da Malvina uma andadura esquipada, muito bonita e doce, que fazia dançar dum belo jeito o roupão da cavaleira. O Lope virou de conversa:

- Agora, falando um pouco de verdade, o Rodrigo não fez cainhage nem ridiqueza c'a filha: aprontou-lhe uma rica festa, vestiu-a feito uma rainha, e ainda por cima de tudo lhe dá de presente um cavalo daquele feitio! Bom cavalo, compadre, repare bem: é tocar-lhe um pouco na rédea, pega num picado lindo que dá gosto; é afrouxar a mão outro pouco e descansar-lhe o corpo em riba, sai-se desvirilhando numa balancinha que parece uma rede. Não dá trabalho nem um, tem todo o preceito!

Mas o Agostinho ficara ainda em nhá Gertrude. E foi c'uma voz carregada de tristeza que ele respondeu ao outro:

- Qual! Como a Gertrude não hai! Aquilo é que era mulher! 


\section{$\underline{\text { Análise do conto }}$}

"Paixão de raiz" é um dos treze contos considerados por Carmen Lydia de Souza Dias como híbridos, por apresentarem uma combinação discursiva mais ou menos homogênea entre uma linguagem coloquial culta e uma coloquial sertaneja. Os outros contos híbridos são: "Mutirão", “À hora da prisão", "Bocó-de-mola”, "João Maçarico”, "Quebrante”, “Ânsia antiga", "Soberbia", "Soneira brava", "Reis", "Forte teima!", "Os guaxes" e "Na rua do Bosque".

Podemos observar a combinação discursiva entre o coloquialismo culto e o coloquialismo sertanejo na passagem abaixo:

"Foi realmente grande perda, a morte de nhá Gertrude: quem a conheceu, há de até hoje repetir que era de dar tristeza um acontecimento assim. Apesar de terem já passado uns três anos, o pessoal do Mandaguari ainda a pranteava. Nhá Gertrude deixou umas quatro dúzias de comadres esparramadas pelo mundo: umas que a procuravam meio às escondidas, pra lhe pedirem que batizasse o pobre dum anjinho que não tinha pai; outras, que mandavam os filhos já viçosos à casa dela dizer que a queriam por madrinha; outras, afinal, que propunham no meio duma conversa, como se viesse por acaso de talho:

- E não é que nhá Gertrude bem podia levar o meu caçula pra pia?”.

O conto tem como temas a morte e o trabalho doméstico. Como motivo principal, o casamento de Agostinho (que não esquecia de sua falecida mulher, nhá Gertrude) com Malvina. O trabalho doméstico é tematizado por intermédio de nhá Gertrude:

“- Aquilo é que era mulher (dizia o Agostinho, do Mandaguari): nem bem o dia clareava, já lá ia pro terreiro tratar das galinhas e do resto da criação. Dormia comigo na cama, e amanhecia c'os porcos no chiqueiro! Muitas vezes, quando eu acordava, e o sol ainda se via a uma altura pequena, já o café 'tava pronto, a casa varrida e o feijão no fogo. Aquilo é que era mulher!".

O título "Paixão de raiz" nos é particularmente muito curioso e interessante. A expressão, metaforicamente muito significativa, nos remete a um sentimento passional tão forte que imaginamos que quem o sente não consegue dele se desvencilhar, pois "criou raiz" na alma do apaixonado que, no conto, é Agostinho. Sua grande paixão pela falecida mulher parecia eterna. Até mesmo depois de se casar com outra mulher. 
"Paixão de raiz" apresenta muitos arcaísmos. Como exemplo podemos citar os seguintes: “correntia”, "vancê", “cresçuda”, “corenta”, "simple”, "percisa”, “arripiar”, "coiração”, entre outros. 


\section{$\underline{\text { Pazes }}^{86}$}

O vento estava de feição: posto fogo à roça, queimou de alto a baixo, sem falhas nem saltos. Ao meio-dia já tudo era cinza, mais escura ou mais clara, menos em uma antiga reboleira de dedais, em que os troncos, ainda não consumidos pelas chamas, tinham largas bocas amarelas, por onde uma fumaça fina e azul passava, dirigindo-se para a brancura do céu. Já se vinham aproximando os primeiros caranchos e gaviões-pombeiros: e um bem-te-vi dos grandes, que não calculara bem a distância e a força do calor, andou muito tempo cai-nãocai, a voar às tontas, entre um rolo e outro de fumaça.

O Chico Maria acabava também de cobrir o rancho, a palmas de guaricanga. Armara a tucuruva ${ }^{87}$ a um canto, e junto dela acamara lascas e rachões de ceboleiro cuvitinga, lenha pobre, de decoada, a melhor que pôde aparecer por então. Trouxera do córrego uma purunga cheia de água e umas folhas de taioba e puzera-as ao lado da quarta de carás do mato que a mulher tinha avelado, com todo o carinho, para a entrada no ermo.

Mas, decididamente, não se achava satisfeito com a vida, aquele dia. Faziam-lhe mal as faiscações do sol no raso da queimada, aborrecia-o por demais o grazinar das tirivas e dos tuins errantes, dava-lhe tédio o mesmo arrulhar da pombinha-piranga que de cedo se ocultara na folharada de um sobragi vizinho.

Foi triste e amargoso assim que ele viu chegar a mulher e a filha, cada qual mais carregada de trouxas de roupa e de lenços cheios de miuçalha caseira. Acusou-as de muita demora, de o terem deixado até semelhante hora sem uma cuia de café ou uma pinga com

\footnotetext{
${ }^{86}$ Nota CLSD: "O Estado de S. Paulo. São Paulo, 15 out. 1904".

${ }^{87}$ Segundo SOUZA, Bernardino José de. Dicionário da Terra e da Gente do Brasil. $5^{\text {a }}$ ed. Belo Horizonte: Itatiaia, 2004, p. 325-326, tucuruva é um "termo usado em S. Paulo pelos caipiras para designa os cupins (vide esta palavra), quando são abandonados pelas formigas que os constroem. Vimo-lo empregado neste sentido no trabalho de Marciano dos Santos - A Dança de São Gonçalo, publicado na Revista do rquivo Municipal de S. Paulo, vol. XXXIII (março de 1937). Eis o passo referido: 'Aguardam a manhã do di da função para cozrem a carne nos originais fogões que improvIsam com as moradas das térmitas, formigas brancas que há em abundância pelos campos sem cultivo. Enquanto as formigas habitam essa caas que medem até metro e meio de altura, os caipiras as nomeiam de cupins, e quando elas os abandonam, de tucuruvas. Essa habitação com o tempo torna-se duríssima e o cultivador que queria destruí-la só o consegue depois de penoso trabalho. E é com esses sólidos tucuruvas que o caipira prepara o fogão destinado a cozinhar os alimentos para a ceia da função (cerimônia religiosa) de São Gonçalo'. Carlos Teschaeur em seu Novo Dicionário Nacional registra tacuruva pedras que sustentam a panela, trempe, tacurus - usado em S. Paulo - pedras que sevem de trempe ou suporte de panelas em cozinha improvIsada - e tacuruba - S. Paulo - trempe formada de três pedras soltas - aférese de itacuruba - pedaço de pedra - tupi-guarani”.
} 
gengibre, como nos se ele fosse cachorro sem dono. Queixou-se de ardume nos olhos, de dor de cabeça, de moleza nas curvas:

- E enquanto eu 'tava feito um mouro, de tanto trabalhar (disse, afinal, enxugando a testa com o dedo grande da mão esquerda, em forma de garra), enquanto isso o carretão 'tava em casa, mexe-mexendo, sem não se resolver a sair nem a ficar, e esta menina fogueta na certeza andava atrás dos poldros e das potrancas, dos garrotes e das novilhas, pintando a moringuinha!

Nhá Zefa respondeu que não, defendendo-se frouxamente. A canseira da longa caminhada tornara-a sofrida e mansa. Empregou mais calor em falar bem da Mecia, que para o tempo do milho verde ia entrar nos sete anos, e não tinha obrigação de ter tanto juízo e ser tão boa lente como ele Chico Maria ou o doutor juiz de órfãos.

Vendo-se em tão boa companhia nas palavras de nhá Zefa, o patrão do rancho ficou menos azedo, por um instante. Porque de fato, em questões de leitura, tinha sua prosa e sua cisma, carregava um entusiasmo velho. Tanto assim, que gargarejava horas e horas, no meio da caipirada do bairro, pedaços de Carlos Magno e os testamentos da bicharia, explicando textos escuros, colhendo, muito justamente, milheiros de ahs! Admirativos, e fazendo vir, ao lume dos rostos pasmados, visagens de susto ou rugas de viva alegria e riso.

Lembrou-se, porém, que estava com fome. E tudo foi uma dobadoura, de repente: nhá Zefa, que fazia fogo, a Mecia, que rasgava as folhas da taioba, e o Trelém, paqueiro caduco, empurrado a pontapés para todas as bandas. Sob a tucuruva, com pouco, desabrocharam ricas brasas: e um caratinga, logo depois, foi deitado a assar no borralho azul claro.

Tudo parecia ir numa vagareza insuportável. Apesar de que a água fervia, de há muito, com resmungos abafados pela tampa da chaleira, o Chico Maria reclamou:

- C'um foguinho maneiro ansim, o café não sai hoje. Encoste mais um pouco de lenha na mariquinha, bamo’ ver se a água chia!

Assado o caratinga, não se encontrava o caxerenguengue, para fazer a repartição. E como a raiz estava muito quente, houve forte arrelia.

- Também na minha morada tudo suverte sempre, nunca vi! Só eu é que não sumo, isso mesmo não sei por que!

Nhá Zefa não fez mais que mover os ombros. Como dando a entender que aquele um andava a desaparecer volta e meia, sem dizer água vai, por dias e dias, por noites e noites, às 
vezes por semanas. E a pobre da pinhã catuzada que ficasse em casa, sozinha com a filha pequena, numa labuta louca!

A janta estava pronta. Afora os torresmos, que amarelavam num testo de panela, e a farinha de milho, que resplandecia, de alva, numa casca de tatu preparada, tudo o mais ficara nas próprias caçarolas e no caldeirão. O Chico Maria pegou na colher de pau, serviu-se do marumbé. Mas fez uma careta:

- Êta! Feijão paã, meu Deus do céu! Adonde é que você 'tava, nhá Zefa, quando temperou isto?

- O feijão 'tá brabo? (retrucou a mulher, meio azaranzada). Pois não coma! Bote no prato o arroz, enquanto 'tá quente: esse arroz é cana-roxa e 'tá feito bem solto.

Entretanto, provado o arroz, o Chico Maria ainda ficou mais zangado:

- Qual solto, nem meio solto! O que ele 'tá é olhando pra cara da gente, sem sal e sem gordura. Vai ver agora, que a carne que você escolheu também é muxiba pura, vai ver só!

Não chegou a experimentar se a carne era só muxiba. O Trelém rosnara de repente e pulara para o mato, aos gritos, em requinte de rasto picado: acuava agora ao longe, bem firme. A Mecia como que fantasiou:

- Vancê quer ver, pai, que o Trelém 'tá fuçando alguma onça?

Ora, onça! Bem mostrava, a Mecia, que só depois do milho verde é que havia de passar para os oito anos! Uma onça em tais arredores! Mas, pouco a pouco, foi ficando banzativo, à medida que a acuação aumentava:

- Olhe, nhá Zefa, como aquela acuação 'tá tapada! E se for mesmo um bichinho daqueles da pinta miúda?

Tomou, às pressas, a cuia de café:

- Arre, Nossa Senhora! Que um café, comprido ansim, inté dá intojo!

Pegou na Laporte de dois canos, a rajadinha quebra, escorvou-a e esfogueteou-a, à medida que estumava o cachorrinho:

- Aí, Trelém! Aí vai! Aí vai!

E foi, realmente, a correr como um doido que o Chico Maria afundou no mato. Não tardou muito que a espingarda trovejasse, rijo e seco, e um baque se fizesse ouvir, de corpo despenhado bem do alto de alguma árvore. Logo depois, a voz do patrão do rancho:

- Acuda, nhá Zefa, que o gato apeou! 
Quando nhá Zefa e a Mecia chegaram, já a pintada tinha tido os últimos arrancos. O Trelém mordia-a pelas orelhas e pelos quartos, irritadíssimo, enquanto o Chico Maria se lhe assentava sobre o lombo, vitorioso, com o rosto alegre que nem festa de Natal, e começava a abrir-lhe os olhos e a desafiá-la com muita ironia:

- Faísca esses olhos, gatinho! Bamo’ ver! Alumeia essas brasas, afia essas unhas, perpara esse pulo!

- Apélo! Como é que você tem corage' de matar quem devêra ser a sua mulher, porque era tão irosa como você mesmo?

O Chico Maria, contudo, pensava de modo diverso:

- Eu, iroso? Você 'tá enganada! Eu inté que tenho muito bom coiração, a cara só é que é enfezada, às vezes! Agora, vista a roupa desta salmilhadinha, pra se saber quem é que fica de jeito pior! Quem vê cara, não vê coiração: este bicho é tão patife, que um cachorro que já nem regula, abasta pra ele!

E a Mecia, alisando o pêlo macio da pintada, raciocinou docemente:

- O pai 'tava gabirova duma vez, não 'tava? Pois se você fez que ele ficasse tão munarca, tão importante, tão cheio de si, é porque você é mesmo boa! Agora o que é verdade é que quem morre fica sempre do pior partido!

Uma laçada de cipó-caboclo serviu de corda: a onça foi arrastada até o rancho. Como o grupo, entretanto, passassse por umas caneleiras, uma juruti, que por ali andava às frutas, voou do chão a um ramo, bateu a cauda nas folhas, e começou a espichar e encolher insistentemente o pescoço, dando mostras de duvidar daquele sossego e daquelas pazes... 


\section{$\underline{\text { Análise do conto }}$}

"Pazes", juntamente com "Amaldiçoada" e "Quebrante", é um conto "onde a convivência narrador/ personagem foi satisfatoriamente resolvida, em termos de adequação do discurso, e, portanto, de perspectiva sobre a realidade" 88 . O narrador se aproxima bem mais do mundo caboclo e sua fala, na maior parte do tempo, e adquire as mesmas características lingüísticas da fala das personagens. Ele usa expressões típicas do universo caipira. Podemos verificar isso no trecho abaixo:

"Foi triste e amargoso assim que ele viu chegar a mulher e a filha, cada qual mais carregada de trouxas de roupa e de lenços cheios de miuçalha caseira. Acusou-as de muita demora, de o terem deixado até semelhante hora sem uma cuia de café ou uma pinga com gengibre, como se ele fosse cachorro sem dono".

O uso de algumas construções sintáticas de cunho regionalista revelam a aproximação com o mundo caipira, tais como "foi triste e amargoso assim" e "como se ele fosse cachorro sem dono". É interessante o uso da palavra "amargoso" por parte do narrador. Trata-se de um vocábulo muito usado pelos caboclos para designar aquilo que consideram amargo, com o sentido de triste. Esse uso nos mostra o quanto o narrador se coloca no mesmo nível cultural e lingüístico do objeto de sua representação literária, isto é, o caipira.

Carmen Lydia, apesar de enfatizar a satisfatória resolução da convivência entre narrador e personagens, aponta um problema do ponto de vista da economia da narrativa: em algumas passagens o conto apresenta muitas descrições, o que "lhe exaurem a vitalidade estilística" 89 .

Um significativo exemplo de descritivismo por parte do narrador pode ser observado na passagem que se segue:

"Vendo-se em tão boa companhia nas palavras de nhá Zefa, o patrão do rancho ficou menos azedo, por um instante. Porque de fato, em questões de leitura, tinha sua prosa e sua cisma, carregava um entusiasmo velho. Tanto assim, que gargarejava horas e horas, no meio da caipirada do bairro, pedaços de Carlos Magno e os testamentos da bicharia, explicando textos escuros, colhendo, muito justamente, milheiros de

\footnotetext{
${ }^{88}$ DIAS, Carmen Lydia de Souza. Op. cit., p. 195.

${ }^{89}$ Op. cit., p. 195.
} 
ahs! Admirativos, e fazendo vir, ao lume dos rostos pasmados, visagens de susto ou rugas de viva alegria e riso".

$\mathrm{Na}$ passagem acima, o narrador se preocupou bastante em mostrar detalhes do quanto o "patrão do rancho" gostava e sabia contar as histórias que lia para as pessoas ao seu redor, assim como as reações que provocava no público ouvinte. Em termos de economia da narrativa, o narrador poderia ter suprimido as reações da "caipirada", por exemplo.

"Pazes" tem como um de seus motivos principais a alimentação. Os outros são a ignorância, o machismo/ patriarcalismo e o trabalho doméstico. Em relação à alimentação, o conto faz referência a alguns produtos que os caboclos consomem bastante no seu dia-a-dia: torresmo, farinha de milho, marumbé (uma espécie de feijão) e arroz cana-roxa.

O título "pazes" diz respeito ao estado de coisas em que o rancho onde as personagens moravam ficou depois que uma delas, o Chico Maria, matara uma onça pintada que andava próxima do lugar onde vivia. Depois da morte da onça, tudo ficou em paz no rancho:

\footnotetext{
"Uma laçada de cipó-caboclo serviu de corda: a onça foi arrastada até o rancho. Como o grupo, entretanto, passasse por umas caneleiras, uma juruti, que por ali andava às frutas, voou do chão a um ramo, bateu a cauda nas folhas, e começou a espichar e encolher insistentemente o pescoço, dando mostras de duvidar daquele sossego e daquelas pazes...".
} 


\section{Moça do fandango ${ }^{90}$}

Na bocaina do campo, já perto da mata, é que o Armando foi alcançado pela Rosinha. Voltou-se, admirado, e sentiu logo um baque no coração, vendo-a toda demudada de feições, com os olhos a chamejarem e um grande rubor de fúria nas lindas faces cor de rosa.

Não foi preciso dizer-lhe nada. Ela tentou compor os cabelos da testa, que o vento desvairava, como a fúria lhe desvairava a expressão do olhar, e falou-lhe apressada, entre hesitações de gagueira nervosa e repentinos chuviscos de lágrimas:

- Adonde é que você vai p'r este caminho? Nem percisa arresponder, que a reposta eu bem vejo naquela volta, pra arriba dos araticuns! Você assentou, duma vez, de me fazer de chá de canela p'r amór de uma bugra à toa? Já 'tá cansado de mim, quer-me apinchar pra uma banda?

O Armando entrou a sossegá-la:

- Mas, Rosinha, que maluquice antão é essa? Pois a estrada não é pública? Antão eu não posso trocar um carreiro, só porque sea Fulana ou sea Beltrana assiste naquele chão? Vou pra cidade, vou com pressa, não tenho tempo de 'tar escolhendo estrada.

- E garra logo a estrada mais comprida? É ansim que você 'tá com pressa? Pois olhe: não tenha tanta; quem vai devagar é que chega mais cedo.

- Rosinha, eu tenho sido um poço de paciência, não posso mais. Você me traz num langará dos dianhos a troco desta ciumeira desatinada! Agora pega a falar nûa moça que eu nem sei se é gorda ou se é magra, se é bonita ou se é feia. E eu hei de aturar de boca fechada um desespero de vida ansim? Nem que eu não tivesse um pingo de vergonha...

- É, você tem rezão, tem sempre rezão. A coitada de mim que fique encantoada em casa, chorando por seu respeito, passando amarguras velhas, enquanto o meu senhor dão vai viver umas horas arregaladas c'a chavantinha chimbeva!

Houve, no rosto do Armando, uma grande movimentação de impaciência. Como um arapaçu, que andava a trepar ligeiramente pelo tronco rugoso de uma sucupira, garganteasse, de alegre, ao saltar para o entrecruzamento dos galhos, onde ferviam cupins em arranjos de casa, o Armando olhou-o, como se nunca houvesse visto semelhante pássaro. Pacificou-se:

\footnotetext{
${ }^{90}$ Nota CLSD: “O Estado de S. Paulo. São Paulo, 16 set. 1905”.
} 
- Isso não é verdade, meu bem. Você não aprova que eu tenha feito pó na porta da Gabriela. Isso é pura canelage!

A Rosinha passou a manga direita nos olhos alagados de pranto:

- Mas já me tenham dito que você gosta da trigueira, e você pra mim não tem mesmo muito créito, porque olha pra uma e pra outra, volta e meia, como quem quer a china e a descascada, a guarapuava e a Nanica, e redondinha e a espigada...

- E eu é que tenho obrigação de agüentar o que você me quiser dizer, desaforos de todo o porte, xingamentos e malcriações, como se eu fizesse algum crime contra você? Donde foi que você me veio, sea Rosinha: foi do céu ou foi do inferno?

- Foi do inferno... Isso foi!

Ela sentou-se num solais do caminho. Os cajueiros e as pitangas em flor, ficando-lhe sobranceiros, cobriam-na de uma brancura de sonho. E foi quase recostada entre as hastes frágeis, que a Rosinha, toda arquejante e cheia de arrepios pelo corpo formoso e pequenino, começou a soluçar.

O Armando, agora, contemplava-a. Tinha-lhe pena. Se lhe pudesse ter amor! Quando foi embrandecendo a tempestade de choro, ele chegou a preparar-lhe, como quem prepara uma cama leve e cheirosa, frases de carícia e de mimo. Mas a Rosinha ergueu o rosto.

- Eu era ruim, não era, Armando? Eu 'tava na desgraceira? Mas antão não fiquei boa? Se eu já fui diabo e agora sou santo, você não devera de me dizer uma palavra tão doída, que me corta ansim o meu coiração! Eu não era mesmo boa, mas tive amor por você, salveime dos meus pecados, caindo nos seus braços e querendo ser tudo que é direito no mundo, só porque lhe quero bem!

Ainda lhe vinham soluços. Venceu-os, porém:

- Você não tem medo de Deus, Armando? Não acha que é falta de piadade largar à toa ûa mulher que se arrependeu de seus passados como quem se arrepende da morte? Olhe, Armando: não vá p'r esse caminho, de caridade, que isso me faz um desespero no fundo da minh'alma!

- Ora isso vou: pois eu hei de agora trocer meu rumo por causa de uma libuzia sem pé nem cabeça? Vou.

- Vá, pois vá! Você bem sabe o que faz... 
Ele pôs-se a caminho, a toda a pressa. Não tornou para vê-la. Não quis ouvi-la mais. O cheiro vivo das gabirobas atordoava-o, fazia-lhe uma quase vertigem o zumbir desordenado das mamangavas e dos inchus errantes.

( -... Vá, que você nunca mais não me há de fazer outra, marvado!)

E um monótono grasnar de caracarás, perseguidos pela passarinhada miúda, pouco a pouco o afastava de toda a lembrança destas coisas, para desejos novos, para alegrias novas, para esperanças novas.

Quando chegou, entretanto, ao fim da grande reta onde a estrada se partia, voltou-se. A Rosinha sumira-se. Ao longe, bem ao longe, em toda a extensão percorrida, para trás donde a deixara, ninguém. Nem a poeira, que anuncia ou trai uma vinda ou uma retirada, pairava no $\operatorname{ar} .$.

Torou então a moita de capoeiras. Apenas um leve rasto acusava a passagem da moça. Seguindo-o, internou-se algumas braças na frescura da mata. Viu-a logo de longe, ajoelhada. Chegou-se-lhe diante: viu que pedia de um laço de cipó-cambira trançado à pressa, e toda se arroxeava no começo do estrangulamento. Cortou-o de repente: e o corpo, entregue a si mesmo, caiu entre as folhas tenras de uma samambaínha nova.

O Armando, a agitá-la, a sacudi-la revocando-a à vida, murmurava ansiado:

- Ah! Senhor Deus do céu! Que ûa mulher ansim é um perigo! Inda quando a gente quer bem...

Lá se foi ela, um dia, muito triste, a cavalo e com dois camaradas e com animais adestros, muito bem tratada, e cheia de esperança porque ia esperá-lo em outra terra, onde não morasse a Gabriela, nem outra igual que lhe fizesse sombra e lh'o tirasse.

Ia desaparecendo na dobrada do morro, e o Armando falou pra quem o quis ouvir:

- Não é mesmo? O que é que a gente há de fazer, senão mandar s'embora pra ûa mulher do fandango? 


\section{Análise do conto}

"Moça do fandango" é um conto que tematiza a prostituição. Trata de um caso amoroso entre Armando e Rosinha, uma ex-prostituta.

Rosinha era muito ciumenta e Armando, por conta disso, houvera a separação, o que faz com que a moça tente suicídio. Depois do episódio, ambos decidem se mudar para um local "onde não morasse a Gabriela, nem outra igual que lhe fizesse sombra e lh'o tirasse". Gabriela era uma mulher pela qual Armando, certo dia, tinha "feito pó” em sua porta.

No final do conto, Rosinha parte do local onde moravam "a cavalo e com dois camaradas e com animais adestros" para esperar por Armando "em outra terra". Este, depois da partida, pergunta, aludindo ao modo como a conhecera: em um fandango, isto é, em um baile rural.

“- Não é mesmo? O que é que a gente há de fazer, senão mandar s'embora pra ûa mulher do fandango?”.

Quanto aos aspectos lingüísticos e estilísticos, neste conto o autor não colocou no mesmo nível os discursos do narrador e das personagens. O primeiro mantém-se no plano lingüístico do coloquial culto, enquanto as personagens fazem bastante uso do coloquial sertanejo. Tratase, portanto, de um conto estilisticamente mal resolvido ou, segundo Carmen Lydia de Souza Dias, "estilisticamente imaturo".

Como um bom exemplo do desnível no plano discursivo, observemos a seguinte fala do narrador:

"E um monótono grasnar de caracarás, perseguidos pela passarinhada miúda, pouco a pouco o afastava de toda a lembrança destas coisas, para desejos novos, para alegrias novas, para esperanças novas”.

Na passagem acima, não aparece construção sintática em dialeto. O narrador se mantém no nível do coloquial culto.

Já na fala da personagem Armando, que transcrevemos logo abaixo, podemos observar um significativo teor de coloquialismo sertanejo:

“- Ah! Senhor Deus do céu! Que ûa mulher ansim é um perigo! Inda quando a gente quer bem...”. 
"Moça do fandango" não apresenta grande quantidade de arcaísmos como em contos anteriores. 


\section{Na beirada do taimbé e1 $^{91}$}

- Venha cá, nhá Candota: perciso de conversar com você como quem percisa de água pra matar uma bruta sede. Faz muitos dias que a gente se vê só de longe, e acho eu que o perto é melhor e de mais fácil acomodação pra se entenderem duas pessoas da nossa qualidade. Escuite bem escuitado o que lhe vou dizer e me dê sua reposta já, ou logo, ou no vagar que quiser.

De tal jeito, com palavras maneirosas e voz sossegada, o Zé Missia estava fazendo chão para uma planta que era o seu lindo sonho de anos e anos. Anos e anos! Resoluto e constante, afinal topara em nhá Candota, quando não tinha mais o direito de se gabar de moço, a beleza, a graça e as melhores qualidades de uma boa companheira diante dos homens e de Deus. E cubiçava-a para si...

Quarentão, mas desempenado, de tamanho do meio, mas carnudo e enxuto, firme no andar e nas ações, costumava afirmar a quem o ouvia:

- Minha verdade é que nem a cana do meu punho - uma só. Hão de custar a trocer o meu braço, a minha verdade é que ninguém será capaz de trocer!

Não exagerava nada: sempre foi forçudo e verdadeiro. Quase menino ainda, socou centenas e centenas de taipa, a cruzado por metro. Crescendo na idade e na sustância, torou e rachou muito pau no mato, fez muita cerca de madeira e muito cocho, em roças e invernadas. Desde que perdeu a voz de frango e mereceu mais atenção e respeito, começou a empreitar serviços de todas as cores e qualidades: o feitio de uma casa de pau-a-pique, derrubada de tantos ou tantos alqueires, queimadas, destocamentos, plantações e colheitas. Antes de chegar aos trinta anos, já tinha uma caixa de couro com fechadura de segredo e, dentro da caixa, um pacotão de notas graúdas. Lá veio dia em que pegou nas tais notas, comprou o sítio de fulano Borge por pouco mais de nada, criação de pêlo e pena, carros e caçambas; arranjou, de pancada, tudo quanto se quer no aviamento da lavoura, oito juntas de bois brasinos, que eram uma boniteza, e até cavalo de figuração, grande e baio-camurça, que deu panca e fez barulho nas cercanias.

Foi seu maior empenho, sempre e sempre, não deixar de cumprir promessa alguma. Andavam por isso de boca em boca, afora outros fatos miúdos, dois de espavento, que ele

\footnotetext{
${ }^{91}$ CLSD: "Escrito em Campos de Jordão, em 1938".
} 
gostava de ver lembrados. Certa vez, tendo uma partida de arroz novo para vender, fechou negócio com o Xavierzinho por um conto e duzentos; sabedor disso, veio o Salustiano e lhe ofereceu um conto e quinhentos: ele respondeu que já não tinha mais o arroz, porque o trato estava feito com outro e só faltava a troca do dinheiro pelo artigo. Noutra ocasião, deu o sim de soltar uma casa, que possuía no lugar mais afastado da vila, por cem de cem ao Nato; não havia escrito, era tudo conversado só de beiço: pois apareceu outro pretendente, o Maneco Reis, que pagava doze contos, ele não se entusiasmou nem ficou murcho, e sustentou a combinação dos dez.

Embora não o tomasse a inchação da vaidade, pegava algumas veezs em si, pesava-se por dentro e acabava decidindo que era um bom partido para nhá Candota. Atreveu-se até a apalpar o assunto, quando saíam da missa, num domingo de Ramos; o povaréu mexia-se desajeitadamente por todo o largo da igreja, nhá Candota distraía-se com facilidade, e ele malhou em ferro frio. Não perdia vaza, porém: na mais pequena aberta de conversação, quando estavam apartados dos outros, encartava a sua bisca, e uma por uma fazia declarações corteses, mas decididas. Nunca pôde ir muito adiante: aquele namoro parece que tinha uruca.

Seguiam as coisas mau rumo agora. A vila de São Simão inteira sabia que nhá Candota andava conversando com um tal Chico Peão, sujeito que principiou a ser visto de repente, da noite para o dia, e que não trouxera apresentação para ninguém. De peão não tinha nada, como ele mesmo confessava: o apelido lhe viera do pai, que da infância à velhice lidou com animais, e de quem nada mais recebera senão o apelido. Mais tarde o município todo entrou na certeza de que ele não mentia um pingo, quando contava aquilo...

O Zé Missia atormentou-se. Deu de espreitar nhá Candota, por aqui, por ali e por acolá, de manhã e de tarde, na intenção de esvaziar o espírito e aliviar o coração. Jurou a si mesmo, por segurança, que acabaria propondo o casamento, fosse lá como fosse. Um belo dia cercou-lhe a passagem, como quem não queria estorvar, e só então pôde falar-lhe mais isto e mais aquilo:

- Esse Chico Peão, nhá Candota, é home' que tem estampa e nada amais. Arrebentou de supetão na vila, trazendo animais e qualidade, arreios caros e um camarada sagaz como quê. Ninguém não sabe quem é semelhante home', que o único trabalho que tem feito é jogar carteado com os dinheirosos desta terra. Vejo dizer, mas de carregação, que dito cujo é ladrão de cavalos e andou fazendo suas últimas façanhas lá pros confins do Carmo da Franca. Isso vejo dizer. Pode que seje errado: não quero ter contra a minha alma um falso testemunho 
levantado do pé pra mão. Mas contanto que não hai filho de Deus que de tal Chico Peão possa dar notícia branca ou preta!

Nhá Candota, moça de boa tenência, que era o bate-enxuga na casa dos pais, trabalhadeira e de poucas falas, prestava a melhor atenção ao Zé Missia. E o Zé Missia, ganhando maior coragem, pegou a encarreirar os encartes que imaginara. Aproveitou a ocasião o mais que pôde; principiou a dar uma no cravo e duas na ferradura:

- Você é capaz de formar uma idéia da vida que o Chico Peão lhe perpara, se vier a casar com você? Tendo inté hoje vivido em casa de pai e mãe, na fartura e na paz, porque a sua gente, e você mesma, veve do trabalho e no trabalho, você imagina que tudo correrá como inté hoje? Pois olhe, nhá Candota: eu não intimo c'as minhas propriadades nem c'os meus haveres, mas você sabe muito bem que o meu sitinho não deve nada pra ninguém, é rendoso, tem boas águas e caminhos cuidados. Você sabe muito bem, além disso, que eu faço meus negócios por fora e tenho botado de banda meia dúzia de patacas. E você sabe muito bem que pissuí, de poucos meses pra cá, um chãozinho na cacunda do Tijuco Preto: são quinhentos alqueires, num pedaço de mundo em que o pé de café, quando se encóva de esquadro, chora por não ter mais espaço e lugar pra onde estender os braços e abrir as saias...

Nhá Candota não deixou de impressionar-se. Então havia terra, no mundo, em que o cafeeiro crescia tanto que chegava a querer ir mais longe que o vizinho? Se os de São Simão, do lado da serra, nas manchas de terra vermelha, já eram de admirar logo adiante dos campos e cerrados, encorpando com toda a força, então de que vulto e maneira não seriam aqueles do sertão? O Zé Missia atava o nó:

- O que eu tenho, no fim das contas, não é meu, nhá Candota: será seu e já é seu, porque eu tenho fá em Deus que você me vai aceitar pra marido. Não vai?

Ela virou-se para outro lado, por instantes, como querendo ouvir melhor o cacarejo fino e reiterado de um joão-de-barro que conversava com a companheira, no galho mais alto do cinzeiro próximo. As mesuras que o joão-de-barro e a companheira faziam com as asas, cessaram logo: nhá Candota foi obrigada a voltar-se para o Zé Missia. Deste Zé Missia, afinal, todos gostavam: o pai, a mãe, os irmãos e a caboclada. Ao passo que só ela, "que não valia uma pitada de rapé”, só ela gostava do Chico Peão! E as últimas notícias que lhe haviam chegado nem eram das melhores: à vista de certas ligeirezas de mão que o tal mostrara, da teima com que algumas cartas só enveredavam para ele, e de pequeninas unhadas que se viam noutras cartas, o delegado mandara chamá-lo e lhe dera dois dias para sumir da vila. 
O Zé Missia entrara em rumo diferente:

- Nhá Candota, você 'tá mas é na beirada do taimbéc ${ }^{92}$. Não hai nada que lhe sirva de segurança ou de valência, nessa parage', se você não se forra fugindo do perigo. A pedra é uma só, muito lisa, sem cotovelo' nem lajedo' pros cantos, porque não tem canto nem um. Se você resbala e perde o pé, não hai como não rode pro tombador ${ }^{93}$ abaixo e não vá direitinho inté o fundo do boqueirão. Não tem aí grama nem carqueja, que já por si não serve' de nada, num artigo desses, pra você pôr a mão e 'o menos demorar um quarto de minuto a fúria da caída. No meio do percipício, você já nem é mais nhá Candota, é um pobre corpo sem alma que vai rolando e rolando pro purgatório...

Reforçou aquele discurso de pavor:

- Você 'tá vendo o rebeirão do Tamanduá, lá em baixo, feito uma fita que num ponto se esconde e noutro se amostra de repente, não é? Co'a seca braba que tem havido, ele parece que se estrafega de reiva em cada volta e grita que nem um desesperado na rasoura das tupavas. O rumor do rebeirão inté assusta, e você daqui nem 'tá sentindo nada, não é? Pois também, quando a gente cai no fundo de um taimbé desgrenhado, ninguém não ouve nem não acode...

Despediu-se:

- Nhá Candota, por tudo quanto você estima no mundo, largue mão do Chico Peão! Se você não se aprecata e não arrecua em tempo, aquele anhanga é o seu taimbé!

Mas no dia seguinte, por volta das oito da manhã, vieram contar ao Zé Missia que nhá Candota, em companhia do Chico Peão, tinha atravessado o Tamanduá no clarear. Ele saiu de si, buscou o encosto de um moirão largado, e só entendeu, da conversa que se acendeu cada vez mais em roda do moirão, uma ou duas coisas:

- Pra onde é que aquele desgracionado vai levando a santinha?

- Pro mundo...

\footnotetext{
92 Nota da edição: A respeito de taimbé, nos informa SOUZA, Bernardino José de. Op. cit., p. 306-307: “vide Itaimbé (op. cit., p. 174). Em reforço à opinião de Calage, escrita nas últimas linhas do termo itaimbé, devo aqui registrar que, das notas particulares que me foram fornecidas pelo Marechal Dr. Gabriel Botafogo, consta que taimbé, o memo que itaimbé, Itambé, ou ainda tabimbé, é, no Rio Grande do Sul, um terreno de difícil trânsito a cavalo, cheio de buracos, fossos, etc. Nas baixadas das canhadas são comuns os taimbés".
} 


\section{$\underline{\text { Análise do conto }}$}

"Na beirada do taimbé" tem como um de seus motivos principais um amor mal correspondido, ao qual de nada adiantou a pressão dos que cercavam Zé Missia e nhá Candota, pois, no desenlace do conto, a moça foge com quem realmente amava, o Chico Peão:

"Mas no dia seguinte, por volta das oito da manhã, vieram contar ao Zé Missia que nhá Candota, em companhia do Chico Peão, tinha atravessado o Tamanduá no clarear”.

O título faz alusão a uma grande pedra em falso, pronta para virar. A expressão "na beirada do taimbé" foi usada por Zé Missia para tentar convencer a amada a se casar com ele e a esquecer de Chico Peão, que era procurado pela polícia. A certa altura, ele diz:

“ - Nhá Candota, você 'tá mas é na beirada do taimbé. Não hai nada que lhe sirva de segurança ou de valência, nessa parage', se você não se forra fugindo do perigo".

Do ponto de vista lingüístico, ocorre em "Na beirada do taimbé" o mesmo que no conto anterior, "Moça do fandango": um desnível entre o discurso do narrador (predominantemente em coloquial culto) e o das personagens (em coloquial sertanejo). Este contraste pode ser verificado no parágrafo final do conto, onde aparecem o discurso do narrador e o de duas personagens:

"Mas no dia seguinte, por volta das oito da manhã, vieram contar ao Zé Missia que nhá Candota, em companhia do Chico Peão, tinha atravessado o Tamanduá no clarear. Ele saiu de si, buscou o encosto de um moirão largado, e só entendeu, da conversa que se acendeu cada vez mais em roda do moirão, uma ou duas coisas:

- Pra onde é que aquele desgracionado vai levando a santinha?

- Pro mundo...”.

Interessante notar que o narrador usa nenhuma expressâo ou palavra que faça parte do universo do coloquialismo sertanejo, enquanto que as personagens usam. As formas 
coloquiais utilizadas pelas personagens são: "pra", "pro" e "desgracionado", sendo esta última um arcaísmo de forma. Isso mostra o quanto o discurso do narrador se distancia do das personagens. 


\section{$\underline{\text { Cobras mal acostumadas }}^{9394}$}

- No topo daquele morro, vocês 'tão vendo o cupim macota que ficou solteiro no meio do rapadão? Tem uma história. A bem dizer, não é do cupim a tal história: vem a ser de uma urutu que se arranchou p'r ali ansim...

À frente de sua casa, no Capivari, proseava o Querubino com dois vizinhos, João Vermelho e Tararé, pouco antes do almoço. Iam os dois passando pela estrada, a caminho da vila, quando ele os viu e os convidou a portar. Conversa puxa conversa, falou-se de muita coisa e também de alguns homens e alguns bichos. No ponto em que estavam, o Tararé, sempre caçoísta e brincalhão, reclamou com urgência:

- De cupim ou de urutu, pois que saia a história!

- E, a bem dizer, não é só da urutu: é de uma vaquinha nova da mana Bernarda, chamada Bem Feita, que tinha perdido a primeira cria.

- Daí?

- Daí... Mas porém o melhor é contar o que assucedeu desde o princípio, tim-tim por tim-tim.

"A cria da Bem Feita (que, por sinal, era um bezerro lindo!), morreu picada de cobra. Não se pôde saber onde se deu o acontecimento da mordida, pra campear e matar a cobra. Do que logo se tratou foi de aporveitar o leite da novilha, que era bastante e bom. Dois, três, quatro dias, correu tudo em rumo certo: de manhã e de tarde ela aparecia por si mesma aqui no canto, pra comer sua ração de milho e deixar meio balde de leite...

- Comia ração de milho, aqui no Capivari?

- Intão? Uma vaca de Querubino ou de mana Bernarda não havéra de comer ração de milho? Você 'tá fazendo galhofa, Tararé!

"No quinto dia a Bem Feita não veio de manhã, nem veio no sexto, nem no resto da sumana: apontava p'r aí já despois do café, com jeito que parecia de envergonhada, e c'o peito murcho a conta inteira. A gente perguntava, uns pros outros, admirada e espantada: o que será? O que não será? E ninguém sabia de nada, pra dar reposta que valesse.

\footnotetext{
${ }^{93}$ Nota CLSD: "Escrito em Campos de Jordão, em 1938".

94 Nota da edição: O manuscrito possui versões nas pastas Mucufos e Originaes manuscriptos de Papae (preciosíssimos).
} 
"De tarde, na hora da ração, o leite da novilha não rendia nada. Adonde é que rodava aquele leite, quando se 'tava bem vendo que ela não escondia nem não negava? Quem deu no vinte, a final de contas, foi a própria mana Bernarda, 'maginando e dizendo que naquilo havia capiangage'. Peguemo' a reparar nas idas e vindas da Bem Feita, entre meio do dia, e nada. Fiquemo' de espreita no fechar da tarde, que era quando ela quaji galopeava pra aqui, percurando a segunda ração, e nada. Resolvemo', à vista dos autos, que eu fizesse uma ronda cedinho, desde a premeira ruiva da madrugada, ante' da vaquinha levantar da cancha. E o que eu fui descobrir me deixou c'uma boca deste tamanho!

"Mal e malzinho que principiava o raiar, ela trepava p'r o morro acima, parava no cupim, encostava no cupim e berrava que era uma beleza. A urutu vinha-se arrastando de carreira, no mesmo sofragante, espichava o corpo cupim arriba, grudava a boca na maminha mais cheia, esvaziava aquela, 'garrava a chupar a outra, e ansim por diante. Quando a urutu escorregava inté a grama, dando por acabada a mamação, a Bem Feita abaixava a cabeça pra tal grama atoa que vocês 'tão vendo, e levava uma temporada louca passando a língua naquele pasto matado".

- E daí?

- Daí me perparei co’a minha espingarda baluda, no outro raiar carquei fogo na cacunda da urutu, vim s'imbora pra casa c'o meu coração aliviado. Você 'mó' que também 'tá fazendo galhofa, João Vermelho?

- Não, Querubino: 'tou querendo é só preguntar se a vaquinha não mandou dar parte de você pro delegado. Em todo causo, veja que bato a mão dereita neste portal da sua casa...

- Você 'tá duvidando? E você, Tararé, o que é que pertende co'essa risada que não tem ânimo de abrir?

- Eu, nada. Mas porém quero que você veja que eu bato a maão dereita no outro portal da sua casa...

O Querubino ia-se enfarruscando. Mas lembrou-se de que estava no seu e convidara os dois vizinhos a chegar. Achou de melhor partido fazer como quem não vê ou, quando vê, não ouve. E foi além:

- Pois intão agora vocês vão ouvir uma história mais importante do que essa. Não querendo aquerditar, vocês podem ir apôs de prima Custódia, que mora aí perto, na Lagoinha, e poderá dizer se eu aumento ou ejagéro alguma coisa. O Sá é melhor testemunha ainda. 
"Prima Custódia, vivia muito agoniada, de certo tempo pra cá, por ver que o único filho que Deus lhe deu, e que já ia compretando os cincos meses, cada vez esmagrecia mais. O marido (pobre do Sá!) andava de curandeiro pra curandeiro, tinha inté levado a criança na casa de um doutor afamado que só faltava fazer milagres: o doutor lhe disse que o pequeno não tinha doença, 'tava só padecendo fome, e receitou caldo de laranja e banana assada, pra ajudar o seio da mãe.

"Ora aquilo não deixou de espantar a gente. Pois se prima Custódia era mulher de saúde, comia bem e punha o peito na boca do menino, a bem dizer, toda hora, como podia lá ser que o menino vivesse esganado? Mas porém a gente via, 'o mesmo tempo, que sempre a criança largava do peito chorando e só assossegava c'um paninho açucarado na língua.

“Um dia que o Sá não pôde ir serrar no mato p'r amór de a chuva, 'tava em casa fabricando um pio de nambuguaçu ${ }^{95}$, quando da cumieira caiu um embrulho no chão da sala. O Sá pasmou de ver que o embrulho era uma jararaca; virou os olhos pra um lado e pra outro, e o que achou mais à mão foi uma foice que tinha acabado de encabar. Deu um golpe c'a foice no meio da jararaca, a jararaca partiu-se em dois pedaços, e de cada pedaço correu leite que embranqueceu a sala de fora a fora.

"Ficou-se intão sabendo que a cobra mamava na prima Custódia, enquanto ela 'tava dormindo (e o sono de prima Custódia inda é pesado inté hoje), razão pela qual o Sazinho não ia pra diante. Liquidada a cobra, o Sazinho pegou a engordar e não parou: agora, com perto de onze meses, 'tá um bicho! Paga a pena ver o Sazinho!"

O João Vermelho e o Tararé perderam a reverência, guaiaram duas gargalhadas de botar o mundo abaixo. Antes, porém, que viesse o mundo abaixo, saiu-se o Tararé com uma barbaridade:

- Já vi contada essa história mais bem contada, seo Querubino, você me discurpe. Pra engambelar o inocente, e dar a perceber que era bico de peito o que ia indo, a cobra lhe empurrava o rabinho na boca... Vira, mexe, você pregou na gente o segundo $1^{\circ}$ de abril, duma vezada só. Abastava o da Bem Feita, este agora esparramou que nem água de ladrão. E olhe: entra também num portal da sua casa...

\footnotetext{
${ }^{95}$ Nota da edição: Segundo FERREIRA, Aurélio Buarque de Holanda. Op. cit., p. 1179, nambuguaçu é um brasileirismo que significa a mesma coisa que inhambuguaçu (op. cit., p. 947), que é uma "ave tinamiforme, da família dos tinamídeos (Crypturellus obsoletus (Tem.)), distribuída da Amaz. ao RS, de coloração brunoavermelhada no dorso, cabeça e pescoço escuros, garganta cinzenta, peito castanho-escuro, abdome amarelado com largas faixas pretas na parte posterior. Vive nas matas virgens, alimentando-se de frutos, bagas, sementes e artrópodes. [Var.: inambuguaçu, nambuguaçu, nhambuguaçu, inamuguaçu.]".
} 
Quando o Tararé bateu a palmada no portal, não teve freio nem buçal a fúria do Querubino:

- Você, pra quem o $1^{\circ}$ de abril principia no Ano Bom e arremata depois do Natal, pensa que os outros são da sua iguala? Pra muita gente, nunca não hai na vida nem um dia de mentirage', a verdade se tem de dizer todo dia, haja o que houver: eu sou de gente ansim.

Em tom de zombaria, mas sem dúvida com prudência, o João Vermelho pôs água na fervura:

- Bamo’ dar aqui o chega. Isto não é assunto que mereça faca e revorve’!

Despedidas meio secas. O Querubino não era queimador de campo, não gostou que lhe tomassem por inventadas aquelas duas coisas: tinha amarrado um burro, deixou o burro amarrado. Mas, de repente, caiu em si:

- Por via de bicho ruim, como é cobra, hei de ficar político, daqui pra diante, co'estes dois desmiolados?

Os dois desmiolados já iam dobrar o cotovelo da estrada real, e ouviram a voz do Querubino, levada longe e mais grossa porque saía de uma boca escondida na concha das mãos:

- Pra trás, Vermelho! Pra trás, Tararé! Venham beber o café mofado que eu tenho agora: e um dia na vida vocês hão de ter visto o que é café torrado por mana Bernarda e bebido em tigela de pombinho! 


\section{Análise do conto}

“Cobras mal acostumadas" tem como tema, segundo Carmen Lydia de Souza Dias ${ }^{96}$, o trabalho (genérico). Como motivos principais tem a alimentação, a medicina caseira, outros pretextos para reunião e usos diversos/costumes.

O trabalho é tematizado genericamente porque não está ligado a uma atividade específica. $\mathrm{O}$ conto trata de personagens que vivem no campo e que tiram seu sustento da terra e da criação de animais.

Tem início na forma de um diálogo. Uma das personagens, o Querubino, principia seu caso apresentando a dois vizinhos (João Vermelho e Tararé) um dos dois objetos deste, uma cobra urutu que havia feito morada no topo de certo morro:

“A bem dizer, não é do cupim a tal história: vem a ser de uma urutu que se arranchou p’r ali ansim...”.

Do ponto de vista discursivo, o narrador (que aparece logo abaixo da primeira fala da personagem Querubino) faz uso do coloquialismo culto, sem muitos arcaísmos e nem mesmo regionalismos. As personagens adotam o coloquialismo sertanejo, com o apelo a vários regionalismos. Um exemplo ilustrativo de uso de regionalismo aparece nas primeiras duas linhas do conto:

“- No topo daquele morro, vocês ‘tão vendo o cupim macota que ficou solteiro no meio do rapadão?”.

O regionalismo, no trecho acima, está representado pela palavra macota, grande, enorme. Há vários outros regionalismos no conto, tais como ruiva (que significa vermelhidão da aurora ou do pôr-do-sol), sofragante (que significa no mesmo instante; imediatamente, logo), enfarruscando (que significa zangando) e bucal (que significa cabresto simples).

Os regionalismos misturam-se aos arcaísmos (como assucedeu, aporveitar, sumana, despois e adonde). Essa mistura, que se junta com o coloquialismo culto do narrador, nos proporciona a observação do caráter híbrido do conto. Portanto há um desnível entre o

\footnotetext{
${ }^{96}$ DIAS, Carmen Lydia de Souza. Op. cit., p. 74.
} 
discurso do narrador e das personagens. O primeiro mantém um certo distanciamento das segundas.

Do ponto de vista da categoria do realismo, embasada nas idéias de Georg Lukács, podemos afirmar que o autor buscou ser fiel à realidade do mundo caboclo das personagens (transcrevendo de modo preciso a fala original dos caboclos), porém mantendo certa distância dele, através do coloquialismo culto empregado pelo narrador. Este não chega a sair totalmente de seu universo urbano culto.

A fala do narrador praticamente não apresenta arcaísmos ou regionalismos. Apenas palavras do contexto oral culto. Um bom exemplo disso é o trecho abaixo:

\footnotetext{
“À frente de sua casa, no Capivari, proseava o Querubino com dois vizinhos, João Vermelho e Tararé, pouco antes do almoço. Iam os dois passando pela estrada, a caminho da vila, quando ele os viu e os convidou a portar. Conversa puxa conversa, falou-se de muita coisa e também de alguns homens e alguns bichos".
}

Ainda sobre a categoria do realismo, afirma Carmen Lydia de Souza Dias:

\begin{abstract}
"Qualquer que seja a concepção do mundo, desde que o autor a possua, sua obra resultará numa representação adequada da realidade objetiva, ainda que variem muito os meios de expressão utilizados. Percebe-se, dentro da discussão em torno da rigidez da concepção lukacsiana de realismo, um ponto central: Lukács confia que a conduta literária de fidelidade ao real traz como consequiência inevitável a apreensão e a iluminação das contradições entre realidade objetiva e ideologia de uma dada época. A realidade do processo social só é visível na práxis, no conjunto dos atos e ações do homem. E dizer esta verdade é tarefa do realismo, demolidor dos mitos, dos preconceitos e do obscurantismo que garante a manutenção de uma ordem social injusta" ${ }^{\text {"97. }}$.
\end{abstract}

Segundo Lukács, independentemente da visão de mundo do autor, seu esforço em projetar na literatura a concepção que possui do real (no caso de Valdomiro, a realidade do mundo caboclo) traz à tona as "contradições entre realidade objetiva e ideologia de uma dada época". O desnível entre narrador e personagens em "Cobras mal acostumadas" nos revela uma boa dose de "contradições" entre dois mundos, o do narrador e o das personagens. Um se diferencia do outro, do ponto de vista discursivo.

\footnotetext{
${ }^{97}$ DIAS, Carmen Lydia de Souza. Op. cit., p. 45-46.
} 
Do ponto de vista ideológico, no conto não aparecem juízos de valor por parte do narrador em relação às personagens. Não há nenhuma mensagem de cunho político e social explícita ou implícita no conto. As diferenças se apresentam mais claras do ponto de vista lingüístico.

A respeito do caso contado pela personagem Querubino para seus vizinhos (de duas cobras: uma que mamava numa vaca e outra num bebê) um dado interessante é o fato destes chegarem a duvidar da história contada por aquele. Isso nos revela um significativo dado de realismo do conto, na medida em que é inerente ao contexto dos "causos" caipiras a desconfiança em relação à sua veracidade. $\mathrm{O}$ fato dos vizinhos duvidarem das palavras de Querubino (quando este contou o caso da cobra que mamava em uma vaca) fez este ficar zangado, porém não o impediu de convidar os dois para entrarem em sua casa:

"O Querubino ia-se enfarruscando. Mas lembrou-se de que estava no seu e convidara os dois vizinhos a chegar. Achou de melhor partido fazer como quem não vê ou, quando vê, não ouve".

A última frase do trecho acima nos revela um outro dado muito importante em relação ao espírito dos caipiras: a cordialidade. Mesmo zangado, Querubino convida os vizinhos a entrarem em sua casa, pois "achou de melhor partido fazer como quem não vê ou, quando vê, não ouve". Querubino se zangou, mas não reagiu com violência em relação aos vizinhos.

Mais adiante, quando Querubino conta o segundo "causo" (o da cobra que mamava o leite do seio de uma mulher), Tararé duvida e quase acontece uma briga entre eles. Porém João Vermelho "pôs água na fervura" dizendo:

“- Bamo’ dar aqui o chega. Isto não é assunto que mereça faca e revorve'!”.

Mesmo assim, querubino ficou "enfarruscado" com os dois por terem duvidado de seus "causos" e grita em voz alta, no final do conto:

“- Pra trás, Vermelho! Pra trás, Tararé! Venham beber o café mofado que eu tenho agora: e um dia na vida vocês hão de ter visto o que é café torrado por mana Bernarda e bebido em tigela de pombinho!”.

Podemos observar do trecho acima que Querubino, mesmo zangado com os vizinhos, guarda valores hospitaleiros e cordiais, que são representados por um importante item na alimentação dos caboclos: o café. E nada melhor, numa casa de caboclo, do que um bom “café mofado" e torrado na hora por mãos tão delicadas quanto às de uma carinhosa cabocla. 
$\underline{\mathrm{A}}$

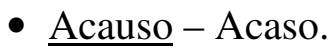

- $\underline{\text { Adestro, }}$ A - Em duplicata, animal que se leva de refresco, em viagem.

- Áfio, áfia - A fio (já se encontra em Camilo).

- $\underline{\text { Afuzilar }}$ - Por fuzilar.

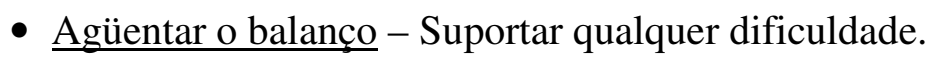

- Alcaide, s.m. - Pássaro da família do tietê, com o peito cor de vinho, as costas de azul ferrete e encontros amarelos.

- Amaguado, A - adj. - Magoado.

- Amargoso, A, adj. - Zangado; valente; bravo.

- Andaaçu, s. m. -Árvore grande, de mato virgem, que dá umas frutas purgativas, muito empregadas em pestes de cavalares e muares.

- Apanhar laranja - Errar as palmas ou o sapateado, no fandango. Também se diz arrebentar laranja.

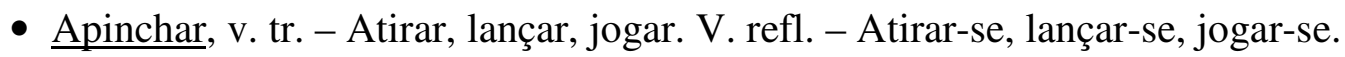

- Aprevenido, A, adj - Por prevenido.

- Aprofiar-Porfiar.

- Arapaçu, s.m. - Pássaro trepador, cor de havana, de bico comprido e levemente curvo.

- Arindiúva, s. f. - Árvore corpulenta, de forte madeira. Também crindiúva e aroeira.

- Arremediado, A. adj - Remediado.

- Arresponder - Por responder.

- Arrivinido, A, adj. - Empedernido, forte, duro.

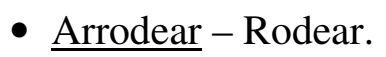

- Arurá, s.m. - Jacaré de papo amarelo. Também lhe chamam ururá e ururau.

- $\underline{\text { Assossegar }}$ - Por sossegar.

- $\underline{\text { Autos }}$ (à vista dos - ) - Em consequência de, em razão de.

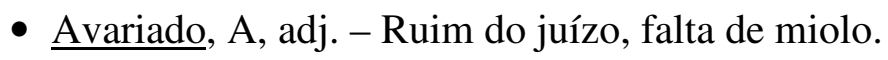

- Azaranzado, A, adj. - Perturbado, desorientado. 
- $\underline{\text { Azeites, }}$ s.m. pl. - Embirração, braveza.

$\underline{B}$

- Bacamarte, s. m. - É o pau em que se enrola o fumo para torcê-lo. Arma de fogo.

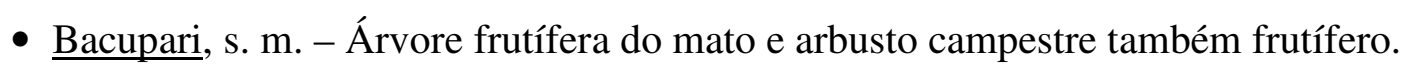

- Bálsimo - Bálsamo.

- $\underline{\text { Barreiro, }}$ s. m. $-1^{\circ}$ ) Terra salitrada, a que chegam os animais. $2^{\circ}$ ) Arbusto conhecido, de brejo.

- Bate-enxuga, s. - A pessoa que mais trabalha, numa casa ou ramo de serviço; a que é mais frequientemente visada como responsável por erros ou faltas aí cometidos.

- $\underline{\text { Beiço }}(\mathrm{de}-$ ) - Sob palavra.

- Benedito, s. m. - Ave trepadora.

- Binga, s. f. - Isqueiro.

- Bisca (encartar uma - ) - Dizer oportunamente, insinuar alguma coisa.

- Bisonho, A, adj. - Manso, tolo.

- Bispar, v. intr. - Enxergar, aperceber, lobrigar, divulgar, ver.

- Bocalmente, adv. de modo - Por boca, vocalmente.

- Bocó-de-mola - Sujeito avariado do juízo, tolo, idiota.

- $\underline{\text { Brabo, }} \mathrm{A}$, adj. - Por bravo, brava, à maneira dos clássicos.

- Bruto, A, adj. - Grande, forte, decidido.

- 'bséquio, s. m. - Por obséquio.

- Bugraria, s. f. - Região habitada por bugres.

- Buzinar, v. intr. - Ficar zangado; ficar enfurecido.

- $\underline{\text { Burro }}$ (amarrar o - ), amarrar um - ) - Ficar zangado. Também se diz emburrar. $\underline{\mathrm{C}}$

- Cainhage, s. f. - Avareza; ridiqueza.

- Caiuá, s. - Tribo de índios mansos do alto Paranapanema.

- $\underline{\text { Canelão, }}$ s. m. - Espécie de canela, madeira de lei.

- Capiangage, s.f. - Ato de furto, ladroíce.

- Capiango, adj. - Gatuno, ladrão.

- Caratinga - Trepadeira conhecida, cará silvestre.

- Carcar fogo - Por acalcar fogo: atirar. 
- $\underline{\text { Carregação }}($ de - ) - Em som de "diz-que-diz-que", ou boato.

- Catiguá, s. m. - Árvore de pouco vulto, mas de madeira muito resistente.

- Catirina, s. f. - Sinônimo de égua.

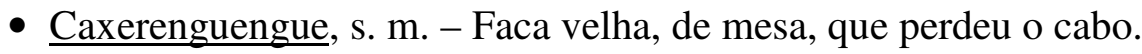

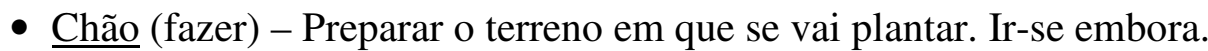

- $\underline{\text { Chão }}$ (pegar) - Fugir.

- $\underline{\text { Chega }}$ (dar o - ) - Cessar em alguma coisa, parar.

- $\underline{\text { Chifrudo }}$ (o) - O diabo.

- Cocão, s. m. - Cada um dos paus verticais, no carro de bois, entre os quais gira o eixo.

- Cochilar no capim, v. intr. - Morrer. O mesmo que pitar, pitar macaia, dar com o rabo na cerca, etc.

- Çoita-cavalo, s.m. - É uma árvore grande, que dá geralmente nos cultivados. O mesmo que guarapereva.

- $\underline{\text { Concho, }}$ A, adj. - Ganjento, presumido, senhor de si.

- Contemplar - Considerar.

- $\underline{\text { Coreto, }}$ s.m. - Canção em louvor de alguém, tirada em geral por uma pessoa e acompanhada, no estribilho, por várias.

- Craminholas, s. f. pl. - Pensamentos vários e desencontrados.

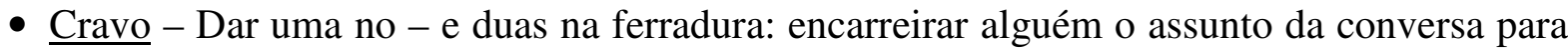
o que lhe convém.

- Crenca, s. f. - Dúvida, disputa, questão, contenda.

- $\underline{\text { Cresçudo, }}$ por crescido, como antigamente teúdo por tido e manteúdo por mantido.

- $\underline{\text { Cuietê, }}$ s. m. - Planta vulgar, de cujo fruto se fazem vasilhas de vário préstimo. Registrado nos dicionários como cuité.

- Cumitério - Cemitério.

$\underline{\mathrm{D}}$

- Dávida, s.f. - Por dádiva.

- Dedal, s. m. - Árvore de mata virgem, cuja madeira serve para pequenas construções, e cortada, lança de si um cheiro como de iodofórmio. Também se chama dedaleira.

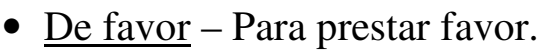

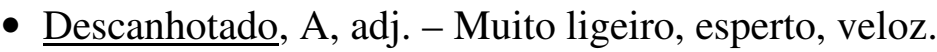


- Descanjicar, v. tr. - Bater com violência em alguma coisa, espatifá-la ou parti-la.

- Desdeixado, A, adj. - Negligenciado.

- Desgrenhado, A, adj. - Basto, denso, fechado, cerrado.

- Desmerecer, v. intr. - Emagrecer, peder as carnes.

- $\underline{\text { De }} \underline{\text { soco }}$ - Subitamente, de supetão.

- Desperpósito - Despropósito.

- Destorcido, A. adj. - E também destorcido: ágil, destro, esperto.

- De tudo - De todo.

- Dicumento - Por documento.

- Dó - Palavra só empregada no feminino.

- Dormideira, s. f. - Sonolência.

- $\underline{\text { Duro, }}$ adj. qual. - Apinhado, repleto, cheio. $\underline{E}$

- Edadoso, A adj. - Idoso.

- Eito, s. m. - Serviço marcado, tarefa. Espaço de tempo.

- Embatucação, s. f. - Redução ao silêncio, desorientação, perturbação, atordoamento, confusão.

- Embira-de-sapo, s. f. - Árvore de tamanho regular, que só dá em terra boa.

- Embirrinchar, v. intr. - Fazer birra, teimar, zangar-se.

- Embodocado, adj. - Arqueado à maneira de bodoque.

- Embonecar, v. intr. - Fazer-se em espigas o milho.

- Encambulhado, adj. - Junto em molhos, de cambulhada, unidamente.

- Enchouriçado, adj. - Entumecido, grosso, inchado.

- Enfiar, v. intr. - Ficar atrapalhado, vexado, envergonhado, calar-se.

- Enricar - Enriquecer.

- Entafulhar, v. intr. - Introduzir, meter dentro, esconder, socar.

- Entojo, s. m. - Enjôo, nojo.

- Escrever, v tr. - Perambular, caminhar por, freqüentar.

- Escurrupichado, A, adj. - Alongado, estendido, espichado.

- Esfrega, s. - Grande trabalho. Surra, pancada.

- Esganado, A, adj. - Esfaimado, faminto. 
- Esganação - Apetite desordenado.

- Esmagrecer - Por emagrecer.

- Especula, adj. 2 gên. - Indagador, curioso, abelhudo.

- Espera-marido, s. m. - Doce feito de açúcar e ovos batidos, a que se ajunta canela e cravo. O mesmo que pra já.

- Estica, s.f. - Elegância. Estar na estica: no rigor da moda, bem trajado, bem vestido.

- Estrafegar, v. trans. - Rasgar, romper, dilacerar.

- Estrangolado, A. adj. - De formas defeituosas. Mal vestido, mal arranjado. Por ext.: de mau procedimento.

- Estrovo - Estorvo.

$\underline{F}$

- Fadista, s. f. - Mulher da vida airada, da comédia; horizontal.

- Família - Filho.

- Feijão-paã - mal cozido, brabo.

- Ferreira (mula) - Que tem o pêlo cor de rato.

- Figuração, s. f. - Representação, luxo.

- Fisiolomia - Fisionomia.

- Fogueto, A, adj. - Desinquieto, sirigaita, que mexe muito, muito saído. O mesmo que mexerendengo e piricica.

- Fora a fora (de) - Em toda a extensão, de princípio a fim.

- Frechar, v. intr. - Caminhar, partir diretamente à maneira da frecha.

- Fuçar, v. tr. - Esfregar o focinho.

$\underline{\mathrm{G}}$

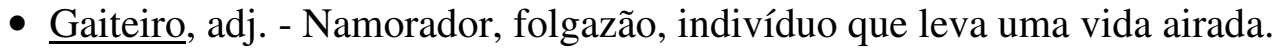

- Galhofa (fazer) - Zombar de alguém, desfrutar alguém.

- Galopear - Galopar.

- Ganchos - Biscates, serviços extraordinários.

- 'Gibeira - Por algibeira.

- Ginerosa-Generosa.

- Granar os olhos - Fitá-los em alguém, ou nalguma coisa.

- Grandecíssimo, adj. superl. de grande. 
- Graxa, s. f. - Banha, gordura, adiposidade.

- Gronga, s. f. - O mesmo que leréia; prosa fiada, léria. Feitiçaria por meio de bebida.

- Guaçatonga, s.f. - Árvore de mata-virgem e de capoeirão, de folhas largas.

- Guaiar, v. - Rir com rumor, gargalhar. Usa-se sempre acompanhado do substantivo: guaiar uma risada, guaiar uma gargalhada.

- Guaiuvira, s. f. - Árvore de mata-virgem.

- Guarapereva, s. f. - O mesmo que çoita-cavalo, árvore conhecida.

- Guaricanga, s. f. - Arbusto que dá nos terrenos úmidos, perto dos brejos, e de que se fazem arcos para peneiras.

- Guasca, s. f. - Relho feito de corda ou de couro.

- Guatapé, s m. - Casca do palmito, em que se deita o mel, misturado com o palmito cortado em pequenas porções.

- Guaxaria, s. f. - Grande quantidade de guaxes.

$\underline{\mathrm{I}}$

- Indrómina, s. f. - Impostura, intrujice.

- Inficionado, adj. - Difícil, penoso, arriscado.

- Influência - Influenza.

- Intendência, s. f. - Ocasião, ensejo, oportunidade.

- Intojo, s. m. - Nojo, repugnância.

- Irara (tirar uma) - Dançar uma contradança qualquer.

- Itapicuru, s.m. - Grande ave preta, de bico curvo, que habita os rios. Anda aos casais. $\underline{\mathrm{J}}$

- Jacutinga, s. f. - Variedade de jacu; difere dos mais por ter a asa branca. Vive no sertão.

- Jantar de cedo - De antes do costume.

- Jatiboca, s. f. - Espécie de taquara.

- Jembê, s. m - Guisado que se faz em Minas de quiabo com galinha e angu.

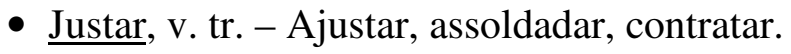

- $\underline{\text { Juntico }}$ - Juntinho.

$\underline{\mathrm{L}}$

- Lagacha, s. f. - Sinônimo de égua. Fig.: rameira, prostituta.

- Langará, s. m - Tristeza, mágoa. Num..., ou no... - De canto chorado. 
- Lenha, s. f. - Cacete, porrete.

- Lente, s. adj. - A pessoa que sabe ler.

- Levado das carepas - Desinquieto, vivo, traquinas, agitado.

- Liberdade, s. f. - Insulto, indireta.

- Lidubina - Ludovina.

- Linha (na) - Na direção.

$\underline{\mathrm{M}}$

- Machetinho, s. m. - Violinha ou cavaquinho.

- Mal-falada, s. f. - Murmuração, intriga, calúnia.

- Mal-feita, s.f. - Crime, delito, e má ação.

- Mamparra, s.f. - Preguiça, demora no trabalho, delonga.

- Mandaçaia, s. f. - Abelha silvestre, que produz excelente mel.

- Manguarão, s. e adj. - Aumentativo de manguara, bengala comprida. Como s. ou adj., significa também o indivíduo de estatura elevada e magro.

- Manjadoura, s. f. - Por manjedoura.

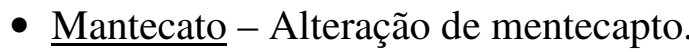

- Marchetada, adj. - Adornada com embutidos de madeiras preciosas, ou marfim, ou madrepérola.

- Mariquinha, s.f. - Tripeça volante, para serviço de cozinha.

- Marumbé, s.m. - Espécie de feijão.

- Matadura, s. f. - Ferida, ferimento.

- Melado, s.m. - Sangue.

- Mexer, v. intr. - Andar. Viajar.

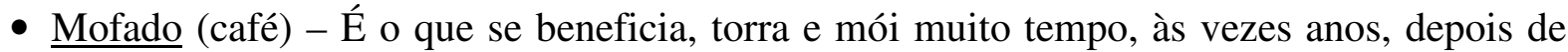
colhido; conserva-se, para isso, em grão e num lugar bem fresco.

- Monjolinho, s.m. - O menor dos maçaricos, ave palustre.

- Mó' que - A modo que, parece que.

- Moriguinha (pintar a) - Divertir-se muito; desmandar-se; exceder-se em alguma coisa.

- Munarca, adj. - Entusiasmado, cheio de si.

$\underline{\mathrm{N}}$

- Navegar, v. intr. - Viajar, caminhar. 
- Nhe-nhe-nhe, s. m - Murmuração.

$\underline{\mathrm{O}}$

- $\underline{\text { Onça }}$ adj. 2 gên. - Forte. Grande. Feroz.

- $\underline{\text { Osta }}$ - Por obsta.

$\underline{\mathrm{P}}$

- $\underline{\text { Palmeio, }}$ s.m.- É o bater das palmas, no fandango.

- Pantasma, s. f. - Por fantasma; visão.

- Paraguaia (cobre) - Chamava-se assim em São Paulo, até certos tempos atrás, a moeda do Paraguai, que entre nós corria com o valor de 40 réis.

- Particular, s. m. - Segredo.

- Papilote, s. m. - Pancada com os dedos, um a um.

- Passarandagem, s. f. - Passagem, artes, sortes que fez o cantador de viola.

- Pauapicada, adj. - De pau-a-pique.

- Pausaria, s. f. - Grande quantidade de paus.

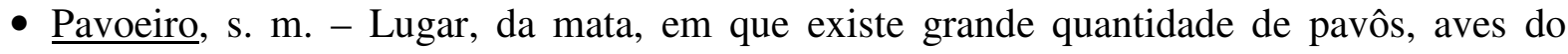
sertão, pretas e de peito vermelho, também conhecidas por pavões do mato.

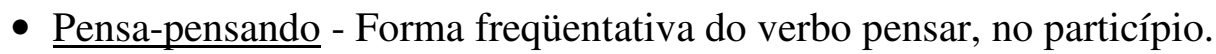

- Pérca, s. f. - Perda.

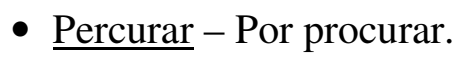

- Perogaia, s. f. - Arbusto de capoeira, que espelha grandes ramas, de folhas quase redondas. É bom remédio contra golpes: põe-se óleo de mamona sobre a folha, e aplica-se sobre a ferida.

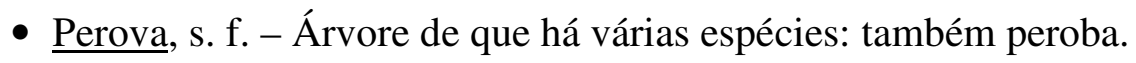

- Perparos - Por preparos.

- Perrengue, adj. - Frouxo, mole, desalentado.

- Picanha, s. f. - Rameira, prostituta.

- Picar, v. - Produzir em instrumento de corda, notas em staccato.

- Picuá, s. m. - Mala, embornal de pano de algodão ou de linho que usam os caçadores. Também se diz sapicuá.

- Piguancha, s. f - Égua. Fig.: rameira, prostituta.

- Pindaíva, s. f - O mesmo que pindaíba. 
- Pinhão, Ã, adj. - Cor de cavalo ou burro.

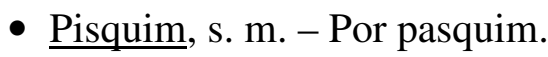

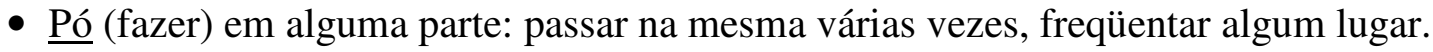

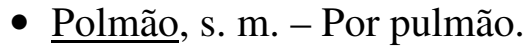

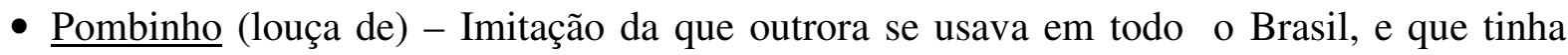
estampadas figuras de pássaro.

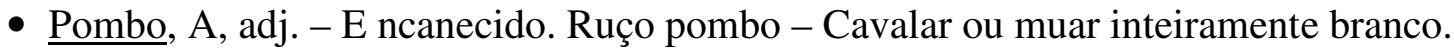

- $\underline{\text { Porte, }}$ s. m - Tamanho, vulto.

- Proporção, s. f. - Tamanho, porte, qualidade.

- Poribir, v. intr. - Por proibir.

- Próprio, s. m. - Mensageiro, recadeiro.

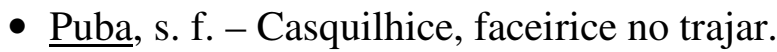

- Puxar pigarro - Fazer menção de cuspir, em ar de provocação a alguém. Q

- Quarenta, s. m. - Moeda de quarenta réis ou dois vinténs.

- Quebrar a munheca - Embriagar-se.

- Quindau, s. m.- Distância longa. Grande distância. É importado de Minas.

- Quiri-quiri, s. m. - Gavião pequeno do campo. $\underline{\mathrm{R}}$

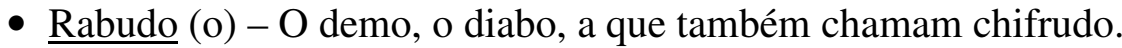

- $\underline{\text { Rasgar, }}$ v. - Na viola, arrastar os dedos, ou o polegar apenas, pelas cordas, sem ponteá-las.

- Rebordosa, s. f. - Pancadaria, barulho.

- $\underline{\text { Refe, }}$ s. m. - Refle; espingarda, barulho.

- Reinar, v. intr. - Trabalhar, esforçar-se.

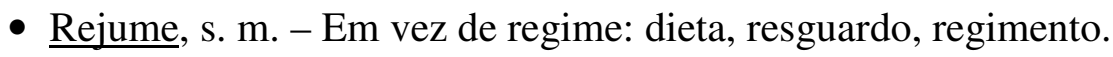

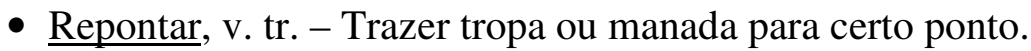

- $\underline{\text { Rezão, }}$ s. f. - Em vez de razão.

- Ridiqueza, s. f. - Avareza.

- $\underline{\text { Rocio }}$, s. m - Roça antiga, aproveitada para capinzal. $\underline{\mathrm{S}}$

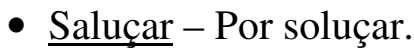


- Samonga, adj. 2 gên. - Lerdo, tolo; idiota.

- Sapuvuçu, s. m. - Árvore copada, que é padrão de terra boa de cultura.

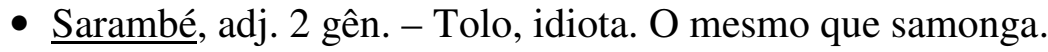

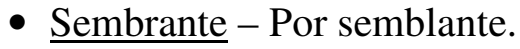

- $\underline{\text { Sem não }-F o r m a ~ d e ~ e x c l u s a ̃ o, ~ e m ~ q u e ~ o ~ n a ̃ o ~ e n t r a ~ a p e n a s ~ c o m o ~ e x p l e t i v a . ~}$

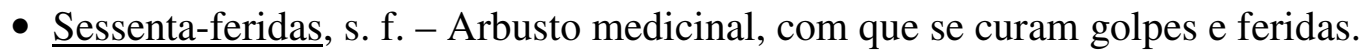

- Sinagoga, s. f. - Reunião, ajuntamento.

- Sintoma - Aparência, parecença, semelhança.

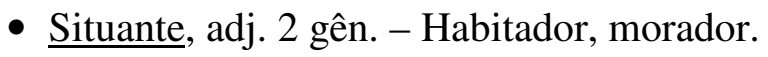

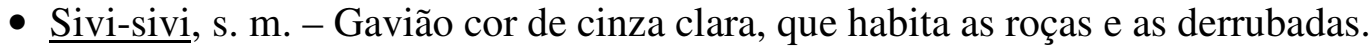

- Sobragi, s. m. - Árvore de mata virgem, que dá boa madeira; também chamada saguaragi.

- Sociadade - Por sociedade.

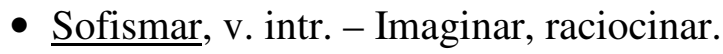

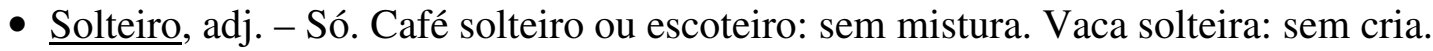

- Songa-monga, s. m. - Indivíduo atoleimado, tolo, idiota.

- $\underline{\text { Sonhos }}$ - Biscoitos de farinha e ovos, fritos em gordura.

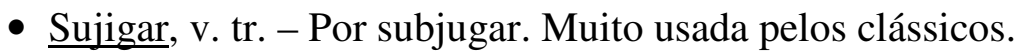

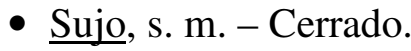

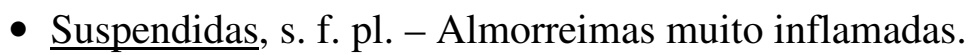

- Sussuaiá, s.m. - Nome do fumo bravo. Também dizem sassuaiá.

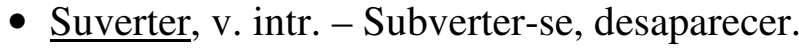
$\underline{T}$

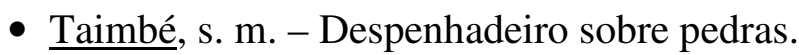

- Taiova, s. f. - O mesmo que taioba.

- Taiuva, s. f. - Amoreira, árvore do mato virgem.

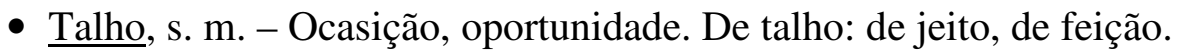

- Tantã, adj. - Desequilibrado, tonto, maluco, aluado.

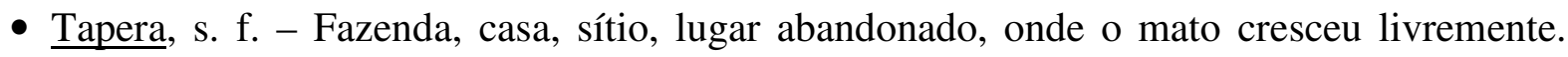
Como adj. dos 2 gên., significa: desarvorado, fora de si, atoleimado, tonto.

- $\underline{\text { Tapiá, }}$ s. m - Árvore de mata virgem, de bom porte. Dá belas flores, e madeira para obras pequenas. 
- $\underline{\text { Tem }}$ - Por haver.

- Tinir, v. intr. - Zangar-se, ficar bravo.

- Tiriva, s. f. - Espécie de papagaio, menor que a nhandaia. Também tiriba.

- Tracuá, s. m. - Planta que dá no cimo das árvores. Tem grande virtude medicinal contra os hernes, em banhos.

- Tramelar, v. - Fechar com tramela.

- Tranqueira, s. f. - É o arroz misturado com qualquer carne de caça do mato ou do campo.

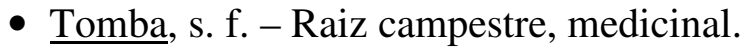

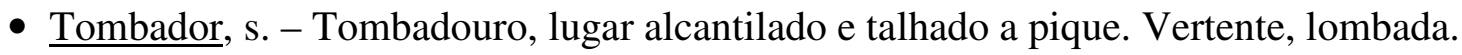

- Tucuruva, s f. - Fogão de três pedras, trempe.

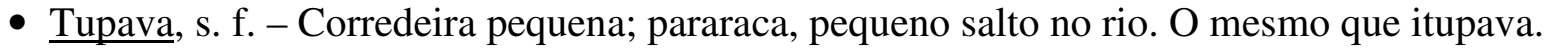

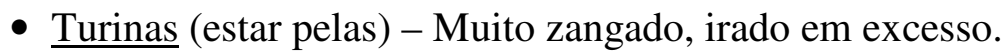

$\underline{\mathrm{U}}$

- Uruca, s. f. - Urucubaca, azar.

- Urupuca, s. f. - Espécie de armadilha para pegar pássaro, feita de pauzinhos miúdos ou de taquara. Outros escrevem urapuca e arapuca. É voz tupi.

$\underline{\mathrm{V}}$

- Vamirim, s. m. - Árvore de mata-virgem. O mesmo que guamirim.

- Veneta, s. f. - Raiva, fúria.

- Ventar, v. intr. - Sair às carreiras, tomado de temor e perseguido por alguém.

- Ventena, s. m. - Sujeito forte, trabalhador, disposto.

- Vermelhinha, s. f. - Jogo de cartas.

- $\underline{\text { Veve }}-3^{\circ}$ pessoa do singular do indicativo presente do verbo viver: vive.

- Viajada, s. f. - Ligação carnal, cópula.

- Violar, v. intr. - Diz-se do amiudar dos galos.

- Virar e romper (de) - Decidido, valente, corajoso. O mesmo que cuera e cumba.

- Vomitório (dar um) - Provocar uma explicação. 
MANUSCRITOS DE VALDOMIRO SILVEIRA NO ACERVO DO ESCRITOR, NO INSTITUTO DE ESTUDOS BRASILEIROS DA UNIVERSIDADE DE SÃO PAULO

\author{
2 PASTAS DE MANUSCRITOS DE VALDOMIRO SILVEIRA \\ NO ACERVO DO ESCRITOR, NO INSTITUTO DE ESTUDOS BRASILEIROS \\ DA UNIVERSIDADE DE SÃO PAULO
}

SILVEIRA, Valdomiro. Mucufos. Manuscrito composto de autógrafos, datiloscritos e textos impressos em periódicos; conservado no interior de pasta de cartolina verde claro $(35,5$ x 25 $\mathrm{cm}$ ), com inscrição a tinta preta: "MUCUFOS"/ "VALDOMIRO SILVEIRA". A pasta contém a relação de títulos e os textos dos contos: Capiango, Maldiçoadal Amaldiçoada, Soberbia, Forte teima!, Paixão de raiz, A consulta do Lau, Quebrante, Na rua do bosque, $\mathrm{Na}$ rua do Bosque (duplicata), Somneira braba, Bocó-de-mola, Moça do fandango, Reis e Pazes.

1. [Relação de títulos e textos]. Autógrafo a lápis; 1 folha; papel vegetal escurecido pelo tempo $(32,5 \times 22 \mathrm{~cm})$; sinais de dobra em cruz. Traz os títulos de 12 contos e 1 crônica:

A consulta do Lau (1 - X - 1902)

Sósinho (18 - 10 - 1902)

Amor na Tulha (16 - XII - 1902)

Castigo do céu (30 - XII - 1902)

Canguíra (17 - III - 1908) - Nas serras e nas furnas

Sonharada (30 - III - 1903) - Leréias

No escuro da noite (22 - IV - 1903) - Leréias

Guarapá (10 - IV - 1903)

Na tapera de nho Tido (5 - IV - 1903) - Nas serras e nas furnas

Gunga-Muquixe (16 - V - 1903)

Chico Mussum (3 - VI - 1903)

Grande amor! - 18 - I - 03

Eu, no sertão - 25 - I - 03.

Nota da edição: Estes títulos não fazem parte do apógrafo de CLSD.

\title{
2. Contos de Valdomiro Silveira
}

2.1. Capiango. Rio de Janeiro, 20 ago. 1899. Datiloscrito original; fita preta; rasuras a lápis preto e a tinta preta; 4 tiras; papel branco escurecido pelo tempo $(33 \mathrm{x} 15 \mathrm{~cm})$; fólios numerados pelo escritor: 2-4; sinal de 2 grampos; escrita ocupando o anverso; assinatura a máquina no final: "Valdomiro Silveira".

Notas VS:

1) Data e local de publicação datilografados no início da $1^{a}$ folha: "O Paiz/ Rio de Janeiro, Domingo 20 de Agosto de 1899 - Anno XV/ No 5432".

2) Observação datilografada no final do texto, $4^{\mathrm{a}}$ folha, referente à obra em que pretendia publicar o texto: "(Nas serras e nas furnas)". 
3) $\mathrm{Na} 1^{\text {a }}$ versão de Capiango, na pasta Originaes manuscriptos de Papae (preciosíssimos), ao final do texto, VS assina a tinta preta, coloca a obra onde ele seria publicado, a data, o local da escritura e a indicação do periódico ao qual foi posteriormente enviado: "Nas serras e nas furnas"/ "Valdomiro Silveira"/ "30 - 50 - 1898"/ "C[asa] B[ranca]"/ "Enviado ao Paiz: $2-$

VIII - 1899".

Notas da pesquisa:

1) O apógrafo de CLSD (Carmen Lydia de Souza Dias) de Mucufos indica redação em Casa Branca, maio de 1898.

2) No apógrafo de CLSD o texto corresponde à versão em autógrafo.

3) A disposição dos textos no apógrafo repete a ordem original dos mesmos, testemunhada pela pesquisadora no manuscrito hoje desaparecido, o qual figurava no arquivo VS, em 19761980.

4) O texto não saiu em Nas serras e nas furnas como havia planejado inicialmente o escritor.

2.2. Maldiçoadal Amaldiçoada. Autógrafo a tinta preta, $1^{\mathrm{a}}$ versão, composto de: 1 folha de papel almaço solta, pautada, papel branco escurecido pelo tempo $(32,5 \times 21,7 \mathrm{~cm})$, assinatura a tinta preta, título do texto, obra em que seria publicado e ano da escritura: "Valdomiro Silveira"/ "Maldiçoada"/ "Os caboclos"/ "1897"; 3 folhas de papel almaço, pautadas, rasuras a tinta preta, papel branco escurecido pelo tempo $(32 \times 21,5 \mathrm{~cm})$, folhas sem numeração, escrita ocupando o anverso e o verso das folhas, assinatura no final: "Valdomiro Silveira".

Nota VS:

1) A tinta preta, data de escritura no final: “26/2/1897”.

Notas da pesquisa:

1) O apógrafo de CLSD de Mucufos indica publicação no periódico paulistano $O$ Estado de $S$.

Paulo, em 10 de fevereiro, 1902, e redação em Santa Cruz do Rio Pardo, 1897.

2) Versão com desfecho diferente ao do apógrafo de CLSD.

3) O texto não saiu em Os caboclos como havia planejado inicialmente o escritor.

2.3. Soberbia. [s.l., s.d.]. Autógrafo a tinta preta; 14 folhas; papel branco escurecido pelo tempo (23,5 x 16,5 cm); numeradas pelo escritor: 2-14; sinal de 2 grampos; escrita ocupando o anverso das 14 folhas; s.a.

Notas da pesquisa:

1) O apógrafo de CLSD de Mucufos indica publicação no periódico paulistano $O$ Estado de $S$ Paulo, em 13 de março, 1902, início de redação em Santa Cruz do Rio Pardo, 1897, e término em Casa Branca, 1902.

2) $\mathrm{Na} 1^{\text {a }}$ versão de Soberbia na pasta Originaes manuscriptos de Papae (preciosíssimos), VS assina a tinta preta, data o conto de 5 de março de 1902 e coloca como local de escritura Casa Branca.

2.4. Forte teima! [s.l., s.d.]. Autógrafo a tinta preta; 22 folhas; papel branco escurecido pelo tempo (23,5 x 16,5 cm); numeradas pelo escritor: 2-22; sinal de 2 grampos; escrita ocupando o anverso das 22 folhas; s.a.

Notas da pesquisa: 
1) O apógrafo de CLSD de Mucufos indica publicação no periódico paulistano $O$ Estado de $S$. Paulo, em 1 de fevereiro, 1902, início de redação em Santa Cruz do Rio Pardo, 1897, e término em Casa Branca, 1902.

2) $\mathrm{Na} 1^{\text {a }}$ versão de Forte teima! na pasta Originaes manuscriptos de Papae (preciosíssimos), VS coloca como ano de início da escritura do conto, 1897, em Santa Cruz do Rio Pardo, como data de término 16 de janeiro de 1902, em Casa Branca, e assina a tinta preta.

2.5. Paixão de raiz. [s.l., s.d.]. Autógrafo a tinta preta; 12 folhas; papel branco escurecido pelo tempo (23,5 x $16 \mathrm{~cm}$ ); numeradas: 2-12; sinal de 2 grampos; escrita ocupando o anverso das 12 folhas; s.a.

Notas da pesquisa:

1) O apógrafo de CLSD de Mucufos indica redação em Casa Branca, 1902.

2) $\mathrm{Na} 1^{\text {a }}$ versão de Paixão de raiz na pasta Originaes manuscriptos de Papae (preciosíssimos), VS assina a tinta preta, indica que o conto pertence a "Eu, no sertão", título da $3^{\text {a }}$ parte de Simplicidade, obra inédita, coloca como local de escritura Casa Branca e o data de 3 de dezembro de 1902.

3) O texto não consta no apógrafo de CLSD de Simplicidade.

2.6. A consulta do Lau. [s.l., s.d.]. Autógrafo a tinta preta; rasuras a tinta preta; 11 folhas pautadas; papel branco escurecido pelo tempo $(23,5 \times 16,5 \mathrm{~cm})$; numeradas pelo escritor: 211; sinal de 2 grampos; escrita ocupando o anverso das 11 folhas; s.a.

Nota da pesquisa:

1) O conto não pertence a Mucufos, segundo CLSD, mas sim a Leréias: histórias contadas por_eles mesmos, livro publicado em 1945.

2.7. Quebrante. Rio de Janeiro, 27 ago. 1897. Datiloscrito original; fita preta; rasuras a tinta preta; 3 folhas; papel branco escurecido pelo tempo $(32,5 \times 11 \mathrm{~cm})$; numeradas pelo escritor: 2-3; sinal de 2 grampos; escrita ocupando o anverso das 3 folhas; assinatura a máquina no final.

Notas VS:

1) Data e local de publicação datilografados na $1^{a}$ folha: "Rio de Janeiro, sexta-feira, 27 de Agosto de 1897./ O Paiz/ Anno XIII/ n 4.711".

2) Observação datilografada no final do texto, $3^{\text {a }}$ folha: “(De um livro inédito de contos, Os caboclos)".

Notas da pesquisa:

1) O apógrafo de CLSD de Mucufos indica publicação no periódico carioca $O$ Paiz, em 27 de agosto, 1897, e redação em Santa Cruz do Rio Pardo, 1897.

2) Conto retirado de $O s$ caboclos, segundo VS. O apógrafo de CLSD indica redação em Santa Cruz do Rio Pardo, 1897.

3) $\mathrm{Na}^{\text {a }}$ versão de Quebrante na pasta Originaes manuscriptos de Papae (preciosíssimos), VS assina a tinta preta, indica que o conto pertence a $O s$ caboclos e o data de 5 de agosto de 1897.

4) O texto não saiu em Os caboclos como havia planejado inicialmente o escritor. 
2.8. Na rua do Bosque. Recorte de texto publicado em $O$ Estado de $S$. Paulo, $\mathrm{n}^{\circ}$ 8678, São Paulo, 1 set. 1902;1 coluna; papel branco escurecido pelo tempo; assinatura impressa no final. Nota VS:

1) A lápis preto: “1 set. 02 ”.

2.9. Na rua do Bosque. [s.l., s.d.]. Recortes; duplicata de texto publicado em [O Estado de $S$. Paulo, $\mathrm{n}^{\circ}$ 8678, de 1 de setembro de 1902]; coluna dividida em 5 recortes colados no anverso de 5 folhas de papel almaço, pautadas; papel branco escurecido pelo tempo $(33,5 \times 22$ $\mathrm{cm})$; numeradas pelo escritor: 1-5; s.a.

Nota VS:

1) A lápis preto, a partir da segunda folha, na parte inferior esquerda: "Na rua do Bosque".

2.10. Somneira braba. s.1., 19 jan. 1902. Autógrafo a lápis preto; rasuras a lápis preto; 7 folhas; papel branco escurecido pelo tempo $(28 \times 21,5 \mathrm{~cm})$; sinal de 2 grampos; escrita ocupando o anverso das 7 folhas; s.a.

Notas da pesquisa:

1) O apógrafo de CLSD de Mucufos indica publicação no periódico paulistano $O$ Estado de $S$. Paulo, em 19 de janeiro, 1902, e redação em Santa Cruz do Rio Pardo, 1897.

2) V. $1^{\text {a }}$ versão sob o título Somneira brava na pasta Originaes manuscriptos de Papae (preciosíssimos), na qual o conto aparece incompleto, em autógrafo a tinta preta; rasuras a tinta preta; 4 folhas; papel almaço branco escurecido pelo tempo $(32,5 \times 21,5 \mathrm{~cm})$; escrita ocupando o anverso e o verso das 4 folhas; sem local e sem data da escritura.

2.11. Bocó-de-mola. [s.l., s.d.]. Datiloscrito original; fita preta; rasuras a lápis preto e a tinta preta; 10 folhas; papel branco escurecido pelo tempo $(27,5 \times 20,5 \mathrm{~cm})$; numeradas: 2-10; sinal de 2 grampos; escrita ocupando o anverso das 10 folhas; s.a.

Nota da pesquisa:

1) O apógrafo de CLSD de Mucufos indica publicação no periódico carioca Gazeta de Notícias, em 1, 2 e 3 de junho, 1897, e redação em Santa Cruz do Rio Pardo.

2.12. Moça do fandango. [s.l., s.d.]. Recorte de [O Estado de S. Paulo. São Paulo, 16 set. 1905]; papel branco escurecido pelo tempo; assinatura impressa.

Nota da pesquisa:

1) O apógrafo de CLSD de Mucufos indica publicação no periódico paulistano $O$ Estado de $S$. Paulo, em 16 de setembro, 1905.

2.13. Reis. [s.1., s.d.]. Datiloscrito original; fita preta; rasuras a lápis preto e a tinta preta; 6 folhas; papel branco escurecido pelo tempo $(27,5 \times 21 \mathrm{~cm})$; numeradas pelo escritor: 1-6; sinal de 2 grampos; escrita ocupando o anverso das 6 folhas; s.a.

Notas da pesquisa:

1) O apógrafo de CLSD de Mucufos indica redação em Casa Branca, janeiro de 1898. 
2) V. $1^{\text {a }}$ versão sob o título Reis na pasta Originaes manuscriptos de Papae (preciosíssimos), na qual VS coloca como local de escritura a cidade de Casa Branca, data o conto de 2 de janeiro de 1898 e assina a tinta preta.

2.14. Pazes. Santos, maio 1942. Texto extraído de Flama: Revista Mensal Ilustrada, a. 21, $\mathrm{n}^{\circ}$ 5, p. 3-4; rasuras a lápis vermelho; 1 folha; papel branco escurecido pelo tempo $(27,3 \times 19$ $\mathrm{cm})$; assinatura do escritor a máquina no início da folha, página 3.

Nota VS:

1) A lápis vermelho, traços delimitando o campo do texto.

Nota da pesquisa:

1) O apógrafo de CLSD de Mucufos indica publicação no periódico paulistano $O$ Estado de $S$. Paulo, em 15 de outubro, 1904.

GONÇALVES, Junia Silveira (ORG.). Originaes manuscriptos de Papae (preciosíssimos). Manuscrito composto de textos de Valdomiro Silveira em autógrafos, datiloscritos e textos impressos em periódicos; 28 documentos conservados no interior de pasta de cartolina bege $(35,5 \times 24 \mathrm{~cm})$; título a lápis preto e a tinta roxa no anverso, na letra da organizadora.

A pasta contém textos dos contos: Maldiçoada, João Maçarico, Cobras mal acostumadas, Castigo do céu, Somneira brava, Forte teima!, Quebrante, Ancia antiga, Soberbia, Capiango, Reis, Paixão de raiz, Os guaxes, Vocação, Cobra mandada, Com Deus e as almas, A reponta, Eu, no sertão, Pae e mãe, Princípio do começo, Princípio do começo (2 ${ }^{\mathrm{a}}$ versão), Grande amor!, A Semana (Folhetim 1), A Semana (Folhetim 2), A Semana (Folhetim 3), A Semana (Folhetim 3) (duplicata), Ternuras e 1 folha solta com a assinatura "Valdomiro Silveira" no anverso e no verso. 